

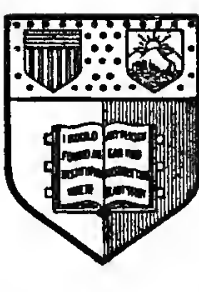

Pew Park

State College of Arriculture

At Cornell Thibersitp

3tbaca. I. 8.

IIthraty 


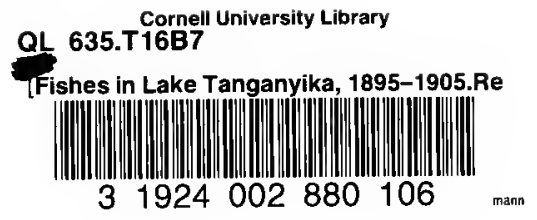




\section{Cornell University Library}

\section{The original of this book is in the Cornell University Library.}

There are no known copyright restrictions in the United States on the use of the text. 


\section{TRANSACTIONS}

OF

\section{THE ZOOLOGICAL SOCIETY \\ OF LONDON.}

Vol. XV.-Pant 1.

\section{O N D O :}

PRINTED FOR THE SOCIETY,

SULD AT THEIK HOUSE IN HANOVER-SQUARE;

AND BY MESSRS. LONGMANS, GREEN, AND CO., PATERNOSTER-ROW.

December 1898.

Price $21 s$. 


\title{
TRANSACTIONS OF THE ZOOLOGICAL SOCIETY OF LONDON.
}

\author{
To Fellows. To the Public. \\ f s. $d . \quad$ \& s. $d$. \\ VOLUME I. (1833-1835, containing 59 Plates). . Price 3136 . . . $4180 *$

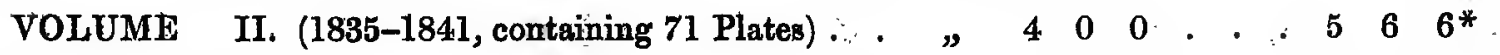 \\ VOLUME III. (184,2-1849, containing 63 Plates) . . „ $\begin{array}{lllllllll}3 & 8 & 3 & . & . & 4 & 11 & 0^{*}\end{array}$

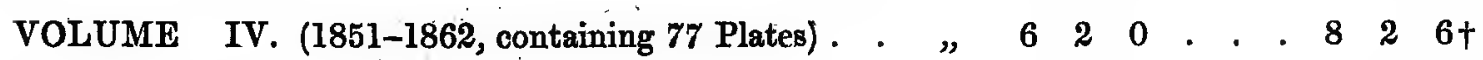 \\ VOLUME V. (1862-1866, containing 67 Plates). . $\quad \begin{array}{llllllllll} & 5 & 4 & 3 & . & . & 6 & 19 & 0 & 0\end{array}$ \\ VOLUME VI. (1866-1869, containing 92 Plates). . „ $\quad \begin{array}{llllllll}11 & 5 & 0 & . & . & 15 & 0 & 0\end{array}$ \\ VOLUME VII. (1869-1872, containing 73 Plates) . . „, $\begin{array}{lllllllll}10 & 4 & 0 & . & . & 13 & 0 & 12\end{array}$

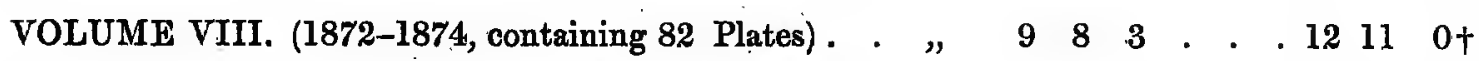 \\ VOLUME IX. (1875-1877, containing 99 Plates). . „ „ $12 \quad 1 \quad 6 \quad . \quad . \quad 16 \quad 2 \quad 0 \dagger$ \\ VOLUME $\quad$ X. (1877-1879, containing 95 Plates) . $\ldots \begin{array}{lllllllllll} & 1 & 0 & 3 & \ldots & . & 13 & 7 & 0\end{array}$

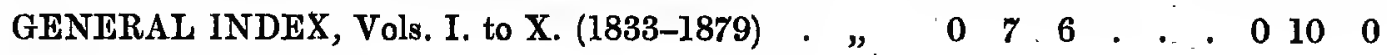

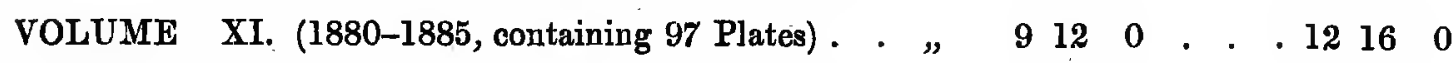 \\ VOLUME XII. (1886-1890, containing 65 Plates) . . $\begin{array}{lllllllllll} & 5 & 8 & 0 & . & . & 7 & 4 & 0\end{array}$ \\ * No copies of these volumes in stock. \\ + Only complete copies of these volumes left in stock.
}

Continued on page 3 of Wrapper. 


\section{T R A N S A C T I O N S}

\section{of \\ THE Z O O L O G I A L S O C I E T Y O F L O N D O N.}

I. Report on the Collection of Fishes made by Mr. J. E. S. Moore in Lake Tanganyika during his Expedition, 1895-96. By G. A. BoulENGER, F.R.S., F.Z.S. With an Appendix by J. E. S. MOORE, A.R.C.S.

Received and read June 21, 1898.

[Plates I.-VIII.]

THE examination of the collection of fishes brought home from Lake Tanganyika by Mr. Moore, and with which I have been entrusted by him, has not yielded any such startling results as have already been announced after study of the Invertebrates ${ }^{1}$. Of the two series in the fauna of Tanganyika, distinguished by its explorer as the normal freshwater and the halolimnic groups ${ }^{2}$, the latter is unrepresented in the collection. This may be due either to the origin of the present fish-fauna not reaching so far back in time as that of the Mollusca and other Invertebrates, or to the incompleteness of the series brought home. The latter explanation may be the correct one, since, owing to the lack of suitable dredging-apparatus, and to the difficulties of preserving, to which Mr. Moore has alluded ${ }^{3}$, only a small proportion of the fishes of the Lake could be collected, mostly littoral forms found about the rocks; of the deeper-water fishes, which were observed to be abuudant both in species and in individuals, we are still almost entirely ignorant; it is therefore to be expected that further collections,

1 J. E. S. Moore, "On the Zoological Evidence for the Connection of Lake Tanganyika with the Sea," Proc. R. Soc. lxii. 1898, pp. 451-458.

2 J. E. S. Moore, “The Molluses of the Great African Lakes," Q. Journ. Micr. Sci. 1898, pp. 159-204.

3 L. c. See also "The Physiographical Features of the Nyasa and Tanganyika Districts," Geogr. Journ 1897.

voL. XV.-PART I. No. 1.-Deceniber, 1898. 
made under more favourable circumstances, would considerably modify our views on the general character of this most important section of the fauna.

How incomplete the collection is may be partly realized from the fact that, of the six species previously described from Tanganyika, only one was rediscovered by Mr. Moore. His series of sketches executed from fresh specimens, free use of which he has kindly given me, thus enabling me to represent some of the new species in their natural colours, also indicate the existence of several fishes wlich are unrepresented in the collection. Large fishes, owing to the impossibility of preserving them, had to be left behind, and the difficulties of transport by carriers resulted in the loss of several jars containing spirit-specimens. Nevertheless, small as it is, and though deficient in any but typically African freshwater forms, the collection is of great interest, and Mr. Moore well deserves the thanks of all zoologists for the manner in which, amid so many difficulties, he has succeeded in affording us a first glimpse at a fish-fauna which has so long remained a mystery.

A study of the freshwater fishes of Africa has hitherto led to the assumption that the bulk of the fauna originated in the region of the great lakes, whence they have radiated towards the Mediterranean and the Atlantic and Indian Oceans-a view based on the close affinity, often amounting to specific identity, of the fishes of the Nile, the Niger, the Congo, and the Zambesi. The homogeneity of the fauna is absolutely opposed to the conception of the great watersheds having been stocked from the sea, within the geological period of which these fishes are representative, this being evident even in the case of such forms as Lates and Tilapia, which are known to enter salt water. Nothing contrary to this theory is brought to light by an examination of the fishes obtained by Mr. Moore in Lake Tanganyika. The striking character of the Tanganyika fish-fauna, as revealed by Mr. Moore's collection, is the extraordinary variety of the Cichlidoe ${ }^{1}$. This is a natural group distributed all over Africa, including Madagascar, but, although rich in species, nowhere else showing within a limited area anything like the modifications of structure described in this report, which have necessitated the establishment of nearly as many new genera as were previously known from the whole of Africa. The generalized characters of some of the Cichlidoe occurring in Lake Tanganyika, regarding as indicative of generalization the greater development of the anal fin, consistently with the system followed in classifying their more primitive allies the Centrarchidoe ${ }^{2}$, and the extent of the lateral lines, both of which are complete in some of the newly-discovered forms ${ }^{3}$, afford further support to the

${ }^{1}$ See P. Z. S. 1898, p. $132 . \quad{ }^{2}$ Cat. Fish. 2nd ed. i. p. 2 (1895).

3 The lateral line has usually been described as "interrupted" in the Cichlidce and other groups in which it has a similar disposition. This expression conveys a serious misconception, and I have replaced it in the diagnoses of the Cichlide and the Serranidae allied to Plesiops by "lateral lines two," the necessity for this change being particularly obvions in the case of some of the species described in this report. Fishes had no doubt originally a greater number of lines of sense-organs along the body, as we may still observe in many of 
proposition enunciated above. Lake Tauganyika might be regarded as the centre of origin of all the African genera of Cichlidoe.

Unfortumately, mothing reliable is yet known of this family in a fossil condition, with the exception of a fer American Tertiary types, which do not differ materially from those inhabiting the same part of the world at the present time. There is no reason for referring to it the Cretaceous fishes from Mount Lebanon described as "Chromides" by Heckel ${ }^{1}$ and by Davis ${ }^{2}$. All we'can gather from Heckel's description is that Pycnosterynx is based on some "Pharyngognath Acanthopterygian," and that it does not belong to the Cichlidce is conclusively proved by his statement: "Rippen kurz, dünn, die hinteren auf langen Querfortsätzen ansitzend," a sentence that has been translated by Davis as "Ribs short and slender, the posterior ones supporting long transverse apophyses" ${ }^{3}$. An examination of some of the specimens of Pycnosterynx exhibited in the British Museum suggests to me special relation to the Berycidoe, with which they are provisionally associated by Mr. Smith Woodward, and certainly no affinity to the Cichlidoe. Considering that coalesced lower pharyngeal bones occur at the present day in such widely different groups ss the Serranaloe, Gerridoe, Scionidoe, Cichlido, Pomacentrida, Embiotocido, Labrida, Scarida, Pleuronectido, and Scombresocidoe, this character, if correctly ascertained by Heckel, would in itself be no serious objection to the allocation of Pycnosterynx among the Berycidos. Günther ${ }^{4}$ also doubts the correctness of Heckel's determination when he states that "the position of Pyonosterynx is uncertain," but we are not enlightened as to its affinities by the further remark that "it approaches certain Pharyngognaths." It appears certain that true Perciform fishes, to which large group the Cichlidoe belong, have not yet been described from pre-Tertiary beds.

In order to show what is now known of the fish-faunas of the great lakes, lists are appended of the fishes of Lakes Nyassa, Tanganyika, Victoria Nyanza, and Rudolf. These lists must of course be taken as giving a very inadequate idea of the fauna, nwing to the incompleteness of the collections on which they are based; but, imperfect as they are, they nevertheless will prove useful as a basis from which to judge of the relation existing between the piscine inhabitants of these lakes. Of the other lakes, unfortunately, nothing can be said at present, the occurrence of an undetermined species of Haplochilus in the Albert Nyanza being all the information we possess.

the lower forms. In the Teleosteans, as a general rule, the lateral lines are reduced to one on each side, extending uninterrupted from the head to the root of the caudal fin, although among this order there is hardly a single large group that does not offer exceptions such as are shown in the Cichlida. In these, both upper and lower lateral lines may be complete; or the upper may be complete and the lower reduced, or the reverse; or the upper may be incomplete posteriorly and the lower anteriorly, which latter disposition has led to the misconception involved in the term " interrupted."

1 Abbild. u. Beschr. n. Thier. Syrien, p. 235 (1843).

${ }^{3}$ L. c. p. 532.

${ }^{2}$ Tr. R. Dublin Soc. (2) iii. 1888, p. 531.

4 'Study of Fishes,' p. 200 (1880). 


\section{Lake Nyassa ${ }^{1}$.}

Cichlidx.

1. Paratilapia robusta Gthr.

2. " afra Gthr.

3. $"$ modesta Gthr.

4. $"$ livingstonii Gthr.

5. $"$ intermedia Gthr.

6. ” dimidiata Gthr.

7. " longiceps Gthr.

8. Corematodus shiranus Blgr.

9. Tilapia shirana Blgr.

10. " mossambica Ptrs.

11. " kirkii Gthr.

12. " squamipinnis Gthr.

13. " rendalli Blgr.

14. „ lateristriga Gthr.

15. ” subocularis Gthr.

16. " johnstoni Gthr.

17. " lethrinus Gthr.

18. " tetrastigma Gthr.

19. " callipterus Gthr.

20. $"$ williamsi Gthr.

21. " aurata Blgr.

22. Docimodus johnstoni Blgr.

\section{Mastacembelidas.}

23. Mastacembelus shiranus Gthr.
SILURID

24. Bagrus meridionalis Gthr.

25. Anoplopterus platychir Gthr.

26. Synodontis zambesensis Gthr.

\section{CyPRINIDA.}

27. Labeo mesops Gthr.

28. Barbus trimaculatus Ptrs.

29. Barilius guentheri Blgr.

30. Engraulicypris pinguis Gthr.

31. Pelotrophus microlepis Gthr.

32. $"$ microcephalus Gthr.

Characinida.

33. Alestes imberi Ptrs.

\section{CYPRINODONTIDA.}

34. Haplochilus johnstoni Gthr.

\section{MORMYRIDA,}

35. Mormyrus discorhynchus Ptrs.

36. ", catostoma Gthr.

37. Mormyrops zambanenje Ptrs.

\section{Lake Tanganyika ${ }^{2}$.}

SerRanides.

1. Lates microlepis Blgr.

Cichlide.

2. Lamprologus fasciatus Blgr.

3. $\quad$ compressiceps Blgr.

4. $"$ moorii Blgr.

5. " modestus Blgr.

6.,$\quad$ elongatus Blgr.

7.,$\quad$ furcifer Blgr.

8. Telmatochromis vittatus Blgr.
9. Telmatochromis temporalis $\mathrm{Blgr}$.

10. Julidochromis ornatus Blgr.

11. Paratilapia pfefferi Blgr.

12. " macrops Blgr.

13. " ventralis Blgr.

14. " furcifer Blgr.

15. $"$ leptosoma Blgr.

16. Ectodus descampsii Blgr.

17. " melanogenys Blgr.

18. Bathybates ferox Blgr.

19. Eretmodus cyanostictus Blgr.

${ }^{2}$ Of. Günther, P.Z.S. 1864, p. 307, 1893, p. 616, and Ann. \& Mag. N. H. (6) xvii. 1896, p. 397 ; Boulenger

P. Z. S. 1896, p. 915, and Ann. \& Mag. N. H. (6) xix. 1897, p. 155, and (7) i. 1898, p. 254.

${ }^{2}$ Gf. Günther, P. Z. S. 1893, p. 628. 
Cichlide (continued).

20. Tilapia tanganice Gthr.

21. " burtoni Grthr.

22. " labiata Blgr.

23. Tropheus moorii Blgr.

24. Simochromis diagramma Gthr.

25. Petrochromis polyodon Blgr.

26. Perissodus microlepis Blgr.

27. Plecodus paradoxus Blgr.

Mastacembelide.

28. Mastacembelus moorii Blgr.

29. " tanganice Gthr.

$30 . \quad$ ophidium Gthr.

Sildridas.

31. Clarias anguillaris $\mathrm{L}$.

32. „ liocephalus Blgr.

33. Anoplopterus platychir Gthr.

34. Auchenaspis biscutata Geoffr.
35. Synodontis multipunctatus Blgr.

36. Malapterurus electricus $\mathrm{Gm}$.

CyPRINIDA.

37. Labeo, sp.

\section{Characinidos.}

38. Alestes macrolepidotus C. \& V. 39. " macrophthalmus Gthr.

40. Hydrocyon forskalii Cuv.

Cyprinodontida.

41. Haplochilus tanganicanus Blgr.

Polypterida.

42. Polypterus bichir Geoffr. (?).

LEPIDOSIRENIDE.

43. Protopterus annectens Ow.?

\section{Lake Victoria Nyanza ${ }^{2}$.}

\section{Cichlide.}

1. Paratilapia longirostris Hilg.

2. ", cavifrons Hilg.

3. " retrodens Hilg.

4. Tilapia nilotica Cuv.

5. " nuchisquamulata Hilg.

6. „ sauvagii Pfeff.'

7. „ obliquidens Hilg.

Mastacembelide.

8. Mastacembelus, sp.

SILURIDA.

9. Clarias, sp.

10. Synodontis afrofischeri Hilg.

CyPRINIDE.

11. Labeo forskalii Rüpp.
12. Labeo rueppellii Pfeff.

13. Barbus pagenstecheri Fisch.

14. " trimaculatus Ptrs.

Characinida.

15. Alestes rueppellii Gthr.

Cyprinodontide.

16. Fundulus taniopygus Hilg.

\section{Mormyride.}

17. Mormyrus oxyrhynchus Geoffr.

18. „, longibarbis Hilg.

\section{LEPIDUSIRENIDA.}

19. Protopterus annectens Ow.

1 Reported from Lake Tanganyika by Sir H. H. Johnston, Brit. C. Afr. p. 362 (1897).

2 Hilgendorf, Sitzb. Ges. naturf. Fr. Berl. 1888, p. 75; Pfeffer, Thierw. O.-Afr., Fische (1896); Günther, Ann. \& Mag. N. H. (6) x vii. 1896, p. 397. 
IV. Lake Rudolf' 1 .

\author{
Cichlida. \\ 1. Tilapia nilotica Cuv. \\ 2. " tristrami Gthr. \\ Siluride. \\ 3. Synodontis schal Bl. Schn. \\ 4. " smithii Gthr. \\ Cyprinida.
}

5. Barbus, sp.
Characinida.

6. Citharinus geoffroyi Cuv.

7. Alestes rueppellii Gthr.

8. Distichodus rudolphi Gthr.

Polypteride.

9. Polypterus senegalus Cuv.

The fishes of Lake Nyassa are, with two exceptions, specifically distinct from those of the Nile, as pointed out by Dr. Günther ${ }^{2}$, while seven out of forty-three species represented in Lake Tanganyika occur both in the Nile and in the rivers flowing into the Atlantic. And as the Mormyride, which furnish the two species common to Nyassa and the Nile ${ }^{3}$, have not yet been recorded from Tanganyika, while, with the exception of a small stream-Siluroid, not one of the species described from the former lake has been rediscovered in the latter, it follows that, although similar in general character, the fish-fauna of the two lakes shows no trace of community so far as specific forms are concerned, as might have been expected from the absence of direct communication between them.

Before concluding these prefatory remarks, I wish to express my thanks to Messrs. J. H. Gardiner and J. Green for their kind assistance in supplying me with sciagraphs of the new fishes, which, supplementing the skeletons prepared by Mr. Groenvold, have enabled me to add some notes on the osteological characters of the genera described as new.

\section{SER R A I D $\mathbb{A}$.}

1. Lates microlepis, sp. n. (Plate I. fig. 1.)

Body elongate, its depth $3 \frac{1}{2}$ times in the total length. Length of head 3 times in total length; upper profile nearly straight; diameter of eye equal to length of snout, $3 \frac{3}{4}$ times in length of head; lower jaw projecting; maxillary extending to below centre of eye, the width of its distal extremity not quite half diameter of eye; præ- and suborbitals finely serrated; cheeks, opercles, and occiput covered with small scales; præopercular border forming nearly a right angle, finely toothed on its vertical limb, with two or three widely-separated spines on its lower limb, and with one or two very

\footnotetext{
${ }^{1}$ Giinther, P.Z. S. 1896, p. 217.

${ }^{3}$ If, as seems prohable, the distinction between Mormyrops zambanenje and M. anguilloides should not be maintained. On the other hand, the Nilotic specimens referred to Mormyrus discorhynchus may prove to be specifically separable. Lake Tanganyika might thus ultimately possess no species of fish in common with the Nile.
} 
strong spines at the angle; opercular spine as much developed as the latter; clavicle with a group of 3 or 4 strong spines. 16 gill-rakers on lower part of anterior arch. Dorsal VII, II 11 ; first and second- spines short, third very strong, longest, $\frac{2}{3}$ length of head; longest soft rays $\frac{2}{5}$ length of head. Pectoral $\frac{1}{2}$ length of head. Anal III 8 ; spines short, second and third equal. Caudal truncate. Caudal peduncle twice as long as deep. Scales 100-110 $\frac{12-13}{29-30}$. Body silvery, spotted and marbled with brown; dorsals spotted with brown; caudal with irregular brown bars.

Total length 155 millim.

Two young specimens from Kinyamkolo.

This species is closely allied to the widely-distributed Lates niloticus Hasselq. Compared to young specimens of the latter, it differs in the smaller scales, the higher spinous dorsal, the longer caudal peduncle, and the shape of the caudal fin, which is truncate instead of rounded.

\section{CHLID}

2. Lamprologus fasciatus, sp. n. (Plate I. fig. 2.)

A few moderately large curved canine teeth in front of each jaw, followed by a narrow band of minute teeth; lateral teeth very small. Depth of body 4 times in total length, length of head 3 . Snout as long as the diameter of the eye, which is 3 times in length of head and equals $1 \frac{1}{2}$ interorbital width; maxillary extending to below anterior border of eye; cheeks naked; opercles and occiput scaled. Gill-rakers short, 12 on lower part of anterior arch. Dorsal XIX 8; spines increasing in length to the last, which measures $\frac{2}{5}$ length of head and nearly equals longest soft rays. Pectoral $\frac{1}{2}$ length of head. Ventral reaching vent. Anal X 6 ; spines increasing in length to the last, which slightly exceeds longest dorsal. Caudal rounded. Caudal peduncle as long as deep. Scales $46 \frac{5}{10}$; lat. 1. $\frac{24-26}{23-26}$. Yellowish, with 11 dark brown bars, the first across the vertex ; fins greyish, dorsal and anal edged with blackish.

Total length 70 millim.

A single specimen from Kinyamkolo.

3. LAMPRologits COMPRLssicers, sp. n. (Plate I. fig. 3.)

A few moderately large curved canine teeth in front of each jaw, followed by a narrow band of minule teeth; lateral teeth very small, curved. Depth of body $2 \frac{1}{2}$ to $2 \frac{3}{5}$ times in total length, length of head $2 \frac{3}{5}$ to $2 \frac{3}{4}$. Head very strongly compressed, with concave upper profile; snout a little longer than diameter of eye, which is 4 times in length of head and equals $1 \frac{1}{2}$ interorbital width; maxillary extending to below anterior border of eye; cheeks naked; opercles and occiput with small scales. Gill-rakers moderately long, 15 on lower part of anterior arch. Dorsal XX-XXI 6 ; 
spines increasing in length to the sixth, which measures half length of head, the posterior a little shorter; longest soft rays a little longer than longest spines. Pectoral $\frac{1}{2}$ to $\frac{3}{5}$ length of head. Ventral produced into a filament. Anal X 5 ; spines increasing in length to the last, which equals the last dorsal ; longest soft rays $\frac{3}{5}$ leugth of head. Caudal rounded. Caudal peduncle as long as deep. Scales 32-33 $\frac{5}{12}$; lat. 1. $\frac{22-23}{9-10}$. Brown, with indistinct traces of five darker vertical bars; pectoral bright yellow, other fins blackish towards the border.

Total length 83 millim.

Two specimens from Kinyamkolo.

\section{Lamprologus Moori, sp. n. (Plate I. fig. 4.)}

9 or 10 equal, moderately large conical teeth in front of each jaw, followed by a narrow band of minute teeth; lateral teeth very small. Depth of body $2 \frac{1}{2}$ times in total length, length of head 3 to $3 \frac{1}{5}$. Snout as long as diameter of eye, which is 3 to $3 \frac{1}{3}$ times in length of head and equals interorbital width; maxillary extending to below anterior border of eye; cheeks with small, deciduous scales; opercles and occiput scaled. Gill-rakers short, 9 or 10 on lower part of anterior arch. Dorsal XIX-XX 8-9; spines slightly increasing in length to the last, which measures nearly half length of head; middle soft rays prolonged, at least $\frac{3}{4}$ length of head. Pectoral $\frac{3}{4}$ to $\frac{4}{5}$ length of head. Ventral prolonged into a long filament. Anal VII-VIII 6-7; spines increasing in length to the last, which is a little longer than the longest dorsal ; middle soft rays prolonged into filamentrs. Caudal rounded. Caudal peduncle as long as deep. Scales 33-35 $\frac{5-7}{11-12}$; lat. 1. $\frac{24-28}{9-13}$. Dark brown; fins blackish.

Total length 93 millim.

Several specimens from Mbity Rocks and Kinyamkolo.

\section{Lamprologds modestus, sp. n. (Plate I. fig. 5.)}

A few large curved canine teeth, tipped with brown, in front of each jaw, followed by a band of minute teeth; lateral teeth very small. Depth of body $3 \frac{1}{3}$ to $3 \frac{2}{5}$ times in total length, length of head 3 to $3 \frac{1}{3}$. Snout a little longer than diameter of eye, which is $3 \frac{1}{2}$ to 4 times in length of head and equals interorbital width; maxillary extending to below anterior border of eye; cheeks naked; opercles and occiput scaled. Gill-rakers very short, 7 on lower part of anterior arch. Dorsal XX 8-9; spines increasing in length to the last, which is not quite half length of head; middle soft rays prolonged, $\frac{2}{3}$ to $\frac{3}{4}$ length of head. Pectoral about $\frac{2}{3}$ length of head. Ventral prolonged into a short filamont. Anal V 6-7; spines increasing in length to the last, which is as long as middle dorsals; middle soft rays prolonged, like the dorsals. Caudal truncate. Caudal peduncle as long as deep. Scales $36-40 \frac{5-6}{12-14}$; lat. 1. $\frac{24-25}{7-11}$. 
Uniform brown; soft dorsal and caudal fins with round black spots between the rays.

Total length 75 millim.

A single specimen from Mbity Rocks, and another from Kinyamkolo.

\section{Lamprologus elongatus, sp. n. (Plate I. fig. 6.)}

6 to 8 large canine teeth in front of each jaw, followed by a broad band of minute villiform teeth; lateral teeth very small. Depth of body 4 times in total length, length of head $2 \frac{3}{4}$ to $2 \frac{4}{5}$. Snout twice as long as diameter of eye, which is 5 times in length of head and equals interorbital width; maxillary extending to below anterior border of eye; cheeks naked; opercles and occiput scaled. Gill-rakers moderately long, 12 on lower part of anterior arch. Dorsal XVIII 10-11; spines slightly increasing in length to the last, which measures $\frac{1}{3}$ length of head; longest soft rays half length of head. Pectoral half length of head. Ventral reaching vent. Anal V 8 ; spines increasing in length to the last, which equals longest dorsal. Caudal truncate. Caudal peduncle $1 \frac{1}{2}$ as long as deep. Scales $90-95 \frac{10}{22-28}$; lat. 1. $\frac{44-56}{20-30}$. Brown, with darker spots having a tendency to form cross-bars; caudal fin with round dark spots between the rays.

Total length 113 millim.

One specimen from Mbity Rocks, and one from Kinyamkolo.

7. LaMPRologus FURCIFrR, sp. n. (Plate II. fig. 1.)

A few large curved canine teeth in front of each jaw, followed by a moderately broad band of minute villiform teeth; lateral teeth very small. Depth of body 4 to $4 \frac{1}{4}$ times in total length, length of head $2 \frac{4}{5}$ to 3 . Snout as long as or a little longer than diameter of eye, which is $3 \frac{1}{2}$ to $3 \frac{2}{3}$ times in length of head and exceeds interorbital width; maxillary extending to below anterior fourth of eye; cheeks and opercles with deciduous scales. Gill-rakers short, 16 on lower part of anterior arch. Dorsal XX-XXI 7-8; spines increasing in length to the last, which measures $\frac{2}{5}$ length of head; middle soft rays produced, $\frac{2}{3}$ to $\frac{3}{4}$ length of head. Pectoral $\frac{3}{4}$ length of head. Ventral reaching vent or origin of anal. Anal VI-VII 6 ; spines increasing in length, the last nearly as long as last dorsal; middle soft rays produced. Caudal deeply notched, crescentic. Caudal peduncle $1 \frac{1}{2}$ as long as deep. Scales $50-54 \frac{6-7}{16-17}$; lat. 1 . $\frac{32-34}{22-31}$; lower lateral line often nearly complete. Dark brown, with very indistinct blackish bars on the body; dorsal and caudal with round black spots between the rays; tips of the caudal lobes whitish.

Total length 125 millim.

Three specimens from Kinyamkolo, and one from Mbity Rocks. voL. XV.-PART I. No. 2.-December, 1898. 
The genus Lamprologus was known from a single species L. congoensis Schilthuis, discovered a few years ago in the Congo. The species now described raise the number to 7 , distinguishable by means of the following key:-

I. Caudal rounded or truncate.

A. Anal with 10 spines.

D. XIX 8 ; Sc. $46 \frac{5}{10}$; depth of body 4 times in total length . . . . . 1. L. fasciatus.

D. XX-XXI 6; Sc. $32-33 \frac{5}{12}$; depth of body $2 \frac{3}{5}$ to $2 \frac{3}{4}$ times in total length. 2. L. compressiceps.

B. Anal with 6 to 8 spines.

D. XIX-XX 8-9; Sc. 33-35 $\frac{5-7}{11-12}$; depth of body $2 \frac{1}{2}$ times in total length . 3. L. moorii.

D. XVIII-XIX 8-10; Sc. $42-53 \frac{6-7}{14-15}$; depth of body $3 \frac{3}{4}$ to 4 times in total length.

C. Anal with 5 spines.

4. L. congoensis.

D. XX 8-9; Sc. $36-40 \frac{5-6}{11-14}$; depth of body $3 \frac{1}{3}$ to $3 \frac{2}{5}$ times in total length . 5. L. modestus.

D. XVIII 10-11; Sc. 90-95 $\frac{16}{22-28}$; depth of body 4 times in total length . 6. L. elongatus.

II. Caudal deeply notched, crescentic.

D. XX-XXI 7-8; A. VI-VII 6 ; Sc. $50-54 \frac{6-7}{16-17}$. . . . . . . . . 7. L. furcifer.

'Telmatochromis, g. n.

Body more or less elongate; scales ctenoid. Jaws with a series of conical teeth, followed by a broad band of minute tricuspid teeth; lateral teeth small, conical. Maxillary exposed. Dorsal with 20 to 22 spines, anal with 6 or 7 . Vertebræ 33 $(16+17)$.

'This genus is closely allied to Lamprologus, differing in the small teeth forming a band behind the outer row being tricuspid instead of conical. It therefore stands somewhat in the same relation to Lamprologus as Tilapia does to Paratilapia.

8. 'Telmatochromis vittatus, sp. n. (Plate II. fig. 2.)

12 to 16 enlarged conical teeth, tipped with brown, in the outer row in each jaw. Depth of body $4 \frac{1}{2}$ to $4 \frac{2}{3}$ times in total length, length of head 4 . Snout descending in a strong curve, as long as or a little longer than the diameter of the eye, which is $3 \frac{2}{3}$ to 4 times in length of head and equals interorbital width; maxillary extending to below the nostril ; head naked, opercle with a few deciduous scales. Gill-rakers very short and tew. Dorsal XXI-XXII 8 ; spines increasing in length to the last, which equals $\frac{1}{2}$ length of head; soft rays a little longer. Pectoral $\frac{3}{4}$ length of head. Ventral produced into a short filament, reaching origin of anal. Anal VII 5-6; spines increasing in length to the last, which equals last dorsal. Caudal rounded. Caudal peduncle as long as deep. Scales $45-52 \frac{6}{16}$; lat. 1. $\frac{25-29}{13-15}$. Yellowish, with a dark 
brown lateral stripe from the upper lip, through the eye, to the base of the caudal, where it expands into a spot; another dark brown stripe from the vertex along the base of the dorsal; a few brown spots on the dorsal; anal edged with dark brown; a black bar at the base of the pectoral, which is white.

'Total length 78 inillim.

Two specimens from Mbity Rocks.

\section{Telmatochromis temporalis, sp. n. (Plate II. fig. 3.)}

8 to 12 enlarged conical teeth, tipped with brown, in the outer row in each jaw. Depth of body $3 \frac{1}{4}$ to $3 \frac{1}{2}$ times in total length; length of head 3 to $3 \frac{1}{4}$. Snout descending in a strong curve, $1 \frac{1}{2}$ as long as the diameter of the eye, which is $4 \frac{1}{2}$ times in length of head and a little less than interorbital width; maxillary extending to below anterior border of eye; head naked, or with a few deciduous scales on the opercles. Gillrakers very short and few. Dorsal XX-XXI 6-7; spines increasing in length to the last, which equals $\frac{1}{3}$ to $\frac{1}{2}$ length of head ; middle soft rays produced, $\frac{2}{3}$ to $\frac{3}{4}$ length of head. Pectoral $\frac{2}{3}$ length of head. Ventral produced into a filament, extending beyond origin of anal. Anal VI-VII 6-7; spines increasing in length to the last, which equals or slightly exceeds last dorsal; soft rays produced, like the dorsals. Caudal rounded. Caudal peduncle as long as deep. Scales $43-46 \frac{6}{12}$; lat. 1. $\frac{25}{9-17}$. Brown, with small round darker spots between the dorsal, anal, and caudal rays; a dark horizontal streak behind the eye; a dark bar at base of pectoral.

Total length 85 millim.

Three specimens from Kinyamkolo, and one from Mbity Rocks.

The deep anterior groove of the skull, in which the ascending processes of the præmaxillaries are received, extends to the anterior third of the orbits. and the strong occipital crest is prolonged forward to it; parietal crests are entirely absent; the chain of suborbital bones is very slender. None of the ribs are sessile, being inserted on a step at the back of the transverse processes of the vertebræ at a short distance from the centre; all bear epipleurals; only the last præcaudal vertebra has a hæmal bridge.

\section{JULIDOCHROMIS, g. n.}

Body elongate; scales ctenoid. Jaws very narrow, with a few curved canines in front, the outer of which are very large and tusk-like, followed on the sides and behind by minute conical teeth forming a narrow band. Maxillary exposed. Dorsal with 22 to 24 spines, anal with 8 or 9 . Vertebræ $34(17+17)$.

This genus represents an exaggerated type of Lamprologus. The very specialized dentition and the general aspect remind one of the Julidine Labridoe, whence the name proposed. 
10. Julidochromis ornatus, sp. n. (Plate II. fig. 4.)

4 or 6 canines in each jaw, tipped with brown. Depth of body 4 to $4 \frac{1}{2}$ times in total length, length of head $3 \frac{1}{3}$ to $3 \frac{1}{2}$. Snout $1 \frac{1}{2}$ to twice as long as diameter of eye, which is $4 \frac{1}{2}$ to 5 times in length of head and $1 \frac{1}{2}$ in interorbital width; maxillary extending to below nostril ; cheeks naked ; opercles scaled. Gill-rakers very short and few. Dorsal XXII-XXIV 5 ; spines equal from the eighth or tenth, $\frac{1}{3}$ length of head ; longest soft rays $\frac{1}{2}$ to $\frac{2}{3}$ length of head. Pectoral about $\frac{2}{3}$ length of head. Ventral produced in a filament, reaching origin of anal. Anal VIII-IX 4-6; spines increasing in length to the last, which equals $\frac{2}{5}$ length of head. Caudal rounded. Caudal peduncle as long as deep. Scales 45-50 $\frac{6-7}{1: 2-13}$; lat. 1. $\frac{26-29}{10-15}$. Yellowish, with three dark brown stripes on each side, the lower from the end of the snout to the base of the caudal, the upper along the base of the dorsal; a large round dark-brown spot on the base of the caudal; a small black spot at the base of the pectoral; anal edged with brown; caudal brown.

Total length 85 millim.

Five specimens from Mbity Rocks.

The præmaxillary groove is deep and extends to the anterior third of the orbits ; the occipital crest is low and continued forward to the præmaxillary groove; parietal crests are present, but very feeble; the chain of suborbital bones is replaced by a ligament ; the mandible is very massive, the lower surface flat, projecting as a keel on the sides. The ribs are inserted on a step of the transverse processes, at a short distance from the centre; all bear epipleurals; only the last præcaudal vertehra has a hæmal bridge.

11. Paratilapia Pfefferi, sp. n. (Plate III. fig. 1.)

Teeth small, in 3 series in each jaw, forming a narrow band, outer largest. Depth of body equal to length of head, $2 \frac{2}{3}$ times in total length. Snout with straight upper profile, as long as eye, the diameter of which is $3 \frac{1}{3}$ times in length of head and equals $1 \frac{1}{2}$ interorbital width ; maxillary extending to below anterior border of eye ; 3 series of scales on the cheek; large scales on the opercle. Gill-rakers rather long, 11 on lower part of anterior arch, the larger spatulate. Dorsal XVI $\varepsilon$; spines increasing in length to the sixtl, which measures a little less than $\frac{1}{2}$ length of head and nearly equals longest soft rays. Pectoral $\frac{4}{5}$ length of head. Ventral reaching origin of anal. Anal III 7 ; third spine longest, as long as longest dorsal. Caudal feebly emarginate. Caudal peduncle $1 \frac{1}{2}$ as long as deep. Scales very finely denticulate on the edge, $33 \frac{3}{9}$; lat. 1. $\frac{21-22}{12-13}$. Pale olive above, silvery beneath, with seven darker vertical bars; fins greyish brown.

Total length 76 millim.

A single specimen from Kinyamkolo. 
This species, which I have much pleasure in naming after the distinguished zoologist of Hamburg, Dr. G. Pfeffer, who has much contributed to our knowledge of East African ichthyology, is nearest allied to P. intermedia Gthr., from Nyassa.

12. Paratilapia macrous, sp. n. (Plate III. fig. 2.)

Teeth small, in 3 series in each jaw, forming a narrow band, outer largest. Depth of body three times in total length; length of head $2 \frac{2}{3}$ to 3 . Snout with straight upper profile, a little slorter than the eye, the diameter of which is $2 \frac{3}{4}$ times in length of head and exceeds interorbital width; maxillary extending to below anterior border of eye ; 2 or 3 series of scales on the cheek; large scales on the opercle. Gill-rakers short, 11 on lower part of anterior arch. Dorsal XVI 10-12; spines increasing in length to the sixth, which measures a little less than $\frac{1}{2}$ length of head and equals longest soft rays. Pectoral as long as head. Ventral extending a little beyond origin of anal. Anal III 6-7; third spine longest, a little shorter than longest dorsal. Caudal with crescentic emargination. Caudal peduncle as long as deep. Scales very finely denticulate on the edge; $33-34 \frac{3}{10}$; lat. 1. $\frac{33}{15-17}$; upper lateral line complete, extending to base of caudal. Pale brownish above, silvery beneath; a series of five indistinct dark blotches on each side of the body; spinous dorsal edged with brown above.

Total length 70 millim.

Two specimens from Kinyamkolo, and one from Mbity Rocks.

Closely allied to the preceding species; distinguished by the larger eye, the complete upper lateral line, the longer pectoral, and the more strongly emarginate caudal. Connects the preceding species with the following, which represents a more aberrant type.

13. Paratilapia ventralis, sp. n. (Plate III. fig. 3.)

Teeth very small, in 2 series in both jaws, the outer larger and tipped with brown. Depth of body $2 \frac{2}{3}$ to 3 times in total length, length of head 3 . Snout with curved upper profile, a little shorter than the eye, the diameter of which is $2 \frac{2}{3}$ to $2 \frac{3}{4}$ times in length of head and exceeds interorbital width; maxillary extending to below anterior fourth of eye; 2 or 3 series of scales on the cheek; large scales on the opercle. Gill-rakers rather long, lanceolate, 17 to 19 on lower part of anterior arch. Dorsal XII-XIII 13-14; spines increasing in length to the eighth or ninth, which measures nearly $\frac{1}{2}$ length of head and $\frac{3}{4}$ or $\frac{4}{5}$ longest soft rays. Pectoral a little longer than head. Ventral much produced, extending far beyond the origin of the anal, especially in the males, in which it may reach the end of the caudal. Anal III 9-10; third spine longest, about $\frac{2}{5}$ length of head; middle soft rays produced, nearly as long as head. Caudal deeply emarginate, crescentic. Caudal peduncle $1 \frac{1}{2}$ as long as deep. 
Scales finely denticulate on the edge, 34-36 $\frac{4}{13-14}$; lat. $1 . \frac{30-36}{10-16}$; upper lateral line complete or nearly so, usually reaching base of caudal. Grey-brown above, with or without irregular darker spots, silvery below; fins grey-brown, the ends of the ventral filaments white.

Total length 92 millim.

8 specimens from Kinyamkolo, and one from Mbity Rocks.

'This species is remarkable among its congeners from continental Africa for the low number of its dorsal spines combined with the large eye, the crescentic caudal, the extremely produced ventrals, and the upper lateral line extending on the caudal peduncle.

\section{Paratilapia furcifer, sp. n. (Plate IV. fig. 1.)}

Teeth very small, in 3 series in both jaws, the outer largest and tipped with brown. Depth of body equal to length of head, 3 times in total length. Snout with curved upper profile, a little shorter than the eye, the diameter of which is $2 \frac{2}{3}$ to $2 \frac{3}{4}$ times in length of head and slightly exceeds interorbital width; maxillary extending to below anterior border of eye; 2 or 3 series of scales on the cheek; large scales on the opercle. Gill-rakers rather long, lanceolate, 15 or 16 on lower part of anterior arch. Dorsal XIII 13-14; spines increasing in lengtl to the ninth, which measures a little less than $\frac{1}{2}$ length of head; some of the soft rays produced, nearly as long as head. Pectoral a little longer than head. Ventral much produced, extending nearly to caudal. Anal III 9; third spine longest, $\frac{2}{5}$ length of head; middle soft rays produced, like the dorsals. Caudal deeply emarginate, crescentic, the rays at the angles produced. Caudal peduncle $1 \frac{1}{2}$ as long as deep. Scales finely denticulate on the edge, $60-63 \frac{4-5}{16-17}$; lat. 1. $\frac{54-55}{28-32}$; upper lateral line nearly complete, extending on the caudal peduncle. Bluish above, white beneath; a few ill-defined yellow streaks along the body; some yellow marblings on the postocular part of the head; fins white, with some yellow streaks on the dorsal and anal and between the ventral and caudal rays (according to a sketch by $\mathrm{Mr}$. Moore).

'Total length 110 millim.

'Two specimens from Kinyamkolo.

Closely allied to the preceding; distinguished by much smaller scales.

\section{Paratilapia leptosoma, sp. n. (Plate III. fig. 4.)}

Teeth small, in 3 series in the upper jaw, in 4 in the lower, outer largest. Depth of body 4 to $4 \frac{1}{3}$ times in total length; length of head 3 . Snout with straight upper profile, as long as or a little longer than the eye, the diameter of which is $3 \frac{1}{2}$ to $3 \frac{2}{3}$ times in length of head, and equals interorbital width ; maxillary extending to below anterior border of eye or not quite so far; 2 series of scales on the cheek; opercle 
covered with scales. Gill-rakers long, slender, and close-set, 20 on lower part of anterior arch. Dorsal XII 14-15; spines increasing in length to the last, which measures $\frac{2}{5}$ length of head, and is nearly as long as the soft rays. Pectoral $\frac{3}{4}$ length of head. Ventral reaching origin of anal. Anal III 10-12; third spine longest, a little shorter than longest dorsal. Caudal feebly emarginate. Caudal pecluncle twice as long as deep. Scales very finely denticulate on the edge, $39-40 \frac{2-3}{11}$; lat. 1. $\frac{27-31}{11-13}$. Brown, lighter beneath; dorsal and anal with or without brown longitudinal streaks; caudal spotted with brown or black at the base.

'Total length 87 millim.

'lwo specimens from Kinyamkolo, and two from Mbity Rocks.

Approaches $P$. longiceps Gthr. in the elongate body, but differs greatly in the dentition, the shape of the snout, and the fin-formula. Only the Malagassy species of the genus Paratilapia were known to have fewer than 13 spines in the dorsal fin; but one of the species described above ( $P$. ventralis) has only 12 or 13 .

\section{Bathybates, g. $n$.}

Body elongate ; scales cycloid, small and irregular. Several rows of large fang-like teeth in the jaws. Maxillary exposed. Dorsal with 14 spines, anal with 3. Vertebræ $36(17+19)$.

This genus is closely related to Paratilapia, with which it is to a certnin extent connected by $\boldsymbol{P}$. longiceps Gthr., from Nyassa. However, the more formidable dentition, coupled with the character of the scales on the body, appear sufficient to warrant the establishment of a new genus. 'The unique species appears in most respects more specialized than Paratilapia longiceps, although more primitive than any known species of that genus in the longer anal fin and the complete upper lateral line.

\section{Bathybates ferox, sp. n. (Plate IV. fig. 2.)}

Teeth long and sharp, fang-like, wide apart, in 4 series in the upper jaw, in 3 in the lower. Depth of body 4 times in tutal length, length of head 3 times. Snout long and strongly compressed, with convex upper profile; eye large, its diameter $1 \frac{2}{5}$ times in length of snout, $3 \frac{1}{2}$ in length of head, and a little greater than interorbital width ; maxillary not quite reaching to below anterior border of eye ; 5 series of small scales on the cheek; large scales on the opercle. Gill-rakers moderately long and slender, 13 on lower part of anterior arch. Dorsal XIV 16; spines rather feeble, sleuder, subequal from the fifth, which measures $\frac{2}{7}$ length of head; longest soft rays $\frac{1}{3}$ length of head. Pectoral $\frac{3}{4}$ length of head. Ventral not reaching vent. Anal III 16 ; spines short and feeble. Caudal deeply forked, middle rays not hc.lf as long as outer. Caudal peduncle nearly twice as long as deep. Scales small and irregular, 
especially below the lateral lines, $78 \frac{i}{38}$; lat. $1 . \frac{78}{44}$; the upper extending from the opercle to the caudal, the lower from below the last dorsal spines to the caudal. Pale bluish green, iridescent above, white below; dorsal and anal bluish grey; ventrals and caudal yellowish; pectorals yellow; two dark streaks on the dorsal.

Total length 275 millim.

A single specimen from Kinyamkolo, taken at a depth of 400 feet. The specimen is a female with ripe ova; these are of large size, measuring $3 \frac{1}{2}$ millim. in diameter. The stomach contains a small, partially-digested fish of the genus Paratilapia, as first ascertained by a sciagraph kindly prepared by Messrs. Gardiner and Green, which has enabled me to compare the structure of the vertebral column with that of other members of the family Cichlidce. The insertion of the ribs is typical, viz., sessile, except on the last three præcaudal vertebræ; the transverse processes are short and in front of the ribs. The number of vertebræ agrees with that of the more elongate species of Paratilapia.

\section{Eretmodos, g. n.}

Body moderately elongate; scales ctenoid. Jaws with rather large spatulate teeth with truncated crowns disposed in oblique transverse rows of two or three. Lips much developed; maxillary entirely concealed when the mouth is closed. Dorsal with 23 to 25 spines; soft rays reduced to 3 to 5 ; anal with 3 spines. Vertebræ 30 $(15+15)$.

A strongly aberrant form, remarkable for its dentition and the structure of the dorsal, formed almost entirely of spines.

17. Eretmodus cyanostictus, sp. n. (Plate III. fig. 5.)

8 or 10 transverse series of teeth in each jaw, the crowns reddish brown. Depth of body equal to length of head, 3 times in total length. Profile of snout curved; length of snout $1 \frac{1}{2}$ to twice diameter of eye, which is $4 \frac{1}{3}$ to 5 times in length of head, and a little less than interorbital width; mouth extending to below nostril; cheeks and opercles naked. Gill-rakers short, 9 or 10 on lower part of anterior arch. Dorsal XXIII-XXV 3-5; spines subequal from the sixth, $\frac{1}{3}$ length of head, a little shorter than soft rays. Pectoral $\frac{3}{4}$ length of head. Ventral reaching vent. Anal III $6-7$; third spine longest, a little longer than dorsals; soft rays about $\frac{2}{3}$ length of head. Caudal rounded. Caudal peduncle deeper than long. Scales $32-35 \frac{3}{11-12}$; Iat. 1. $\frac{22-23}{6-9}$. Blackish brown, with scattered pale blue dots; belly yellowish.

Total length 75 millim.

Five specimens from Mbity Rocks, and three from Kinyamkolo.

The toothed portions of the præmaxillary and mandible are much developed in depth, in a manner suggestive of the Sparidoe and Scarida, and the teeth are implanted in sockets. The deep triangular groove for the reception of the præmaxillaries extends 
to between the orbits, and the occipital crest is prolonged to it; the parietal crests are produced on the frontals; the præorbital is large, and the chain of suborbitals very slender. The pharyngeal teeth have long slender shafts and conical brown cusps. The ribs are attached to the back of short transverse processes; all but the last one support epipleurals; the last four præcaudal vertebræ have a hæmal bridge.

18. Tilapia labiata, sp. n. (Plate V. fig. 1.)

Outer teeth rather large, feebly notched; inner teeth very small, tricuspid, in 3 or 4 series. Depth of body equal to length of head, $2 \frac{2}{3}$ to $2 \frac{3}{4}$ times in total length. Snout with straight upper profile, $1 \frac{1}{4}$ to $1 \frac{3}{4}$ diameter of eye, which is $3 \frac{1}{2}$ to $4 \frac{1}{2}$ times in length of head and equals interorbital width; maxillary not extending to below anterior border of eye; 3 or 4 series of scales on the cheek; large scales on the opercle; lips very strongly developed, both produced into a large triangular lobe in front. Gillrakers moderate, 15 on lower part of anterior arch. Dorsal XVIII 10 ; middle dorsal spines longest, about $\frac{2}{5}$ length of head, and a little shorter than longest soft rays. Pectoral $\frac{3}{4}$ to $\frac{4}{5}$ length of head. Ventral reaching origin of anal. Anal III 6-7; third spine longest, as long as longest dorsals, slightly shorter than longest soft rays. Caudal truncate. Caudal peduncle slightly longer than deep. Scales finely denticulate on the border, $33-35 \frac{5-6}{12-13}$; lat. $1 . \frac{22-25}{13-15}$. Pale olive, with 10 more or less distinct darker cross-bars; fins greyish-brown; dorsal sometimes with oblique dark and light streaks ; caudal with numerous round dark spots between the rays.

Total length 170 millim.

Four specimens from Kinjamkolo.

This species is easily recognizable by the extraordinary development of the lips, which bears a curious resemblance to that observed in the Central American Heros labiatus $^{1}$. It appears to be nearest allied to Ctenochromis nuchisquamulatus Hilg., and $C$. sauvagii Pfeffer, from the Victoria Nyanza.

\section{Tropheus, g. n.}

Body moderately elongate; scales ctenoid. Jaws angularly bent at the sides, with bands of minute tricuspid teeth, an outer row of bicuspid teeth, and enlarged conical teeth at the sides of the præmaxillary; mouth transversely linear when closed; maxillary concealed under the præorbital. Dorsal with 21 spines, anal with 6 . Vertebræ $33(17+16)$.

This genus differs from Tilapia in the angularly-broken præmaxilla armed with enlarged conical teeth at the sides, and the higher number of anal spines.

The name proposed (rpoథeíc, one who rears, brings up, educates) refers to the peculiar mode of nursing the eggs described hereafter.

${ }^{1}$ Günther, P. Z. S. 1864, pl. iv. fig. 1.

VoL. XV.-PART I. No. 3.-December, 1898. 
19. Tropheus MOORII, sp. n. (Plate V. fig. 2.)

Teeth minute, those of the outer series tipped with brown and numbering about 50 . Depth of body $2 \frac{1}{2}$ to $2 \frac{2}{3}$ times in total length, length of head $3 \frac{1}{4}$ to $3 \frac{1}{2}$. Snout descending in a strong curve, as long as or a little longer than the diameter of the eye, which is $3 \frac{1}{2}$ to 4 times in length of head, and equals $\frac{2}{3}$ to $\frac{3}{4}$ interorbital width; mouth extending to below anterior border of eye; 4 series of scales on the cheek; large scales on the opercle. Gill-rakers short, 11 or 12 on lower part of anterior arch. Dorsal XXI 5-6; spines increasing in length to the sixth, wlich measures not quite half length of head; longest soft rays $\frac{2}{3}$ to $\frac{3}{4}$ length of head. Pectoral as long as head. Ventral produced into a short filament, reaching beyond origin of anal. Anal Vl 5-6: spines increasing in length to the last, which slightly exceeds longest dorsal. Caudal slightly notched. Caudal peduncle as long as deep. Scales $30-32 \frac{3}{12}$; lat. 1. $\frac{22-25}{11-12}$. Dark brown; a large bluish-white blotch on each side; belly reddish brown; fins blackish.

Total length 110 millim.

Five specimens from Kinyamkolo.

The occipital crest is very strong and the parietal crests are produced on the frontals. The insertion of the ribs is as described in the preceding genera Telmatochromis and Eretmodus.

The mouth and pharynx of one of the specimens contains four eggs of very large size, the vitelline sphere measuring 4 millimetres in diameter, with an embryo in an advanced stage of development. The egg of the Fifteen-spined Stickleback (Gasterosteus spinachia), hitherto regarded as the largest Teleostean egg in proportion to the size of the animal, measures only 3 millimetres in diameter ${ }^{1}$. Besides the Siluroids of the genera Arius and Galeichthys, which have very large eggs, at least two species of Tilapia were known to give shelter to their eggs in the manner noticed above, viz.. T. simonis Gthr. (Chromis paterfamilias Lortet), as observed by Prof. Lortet in Lake Tiberias, and T. nilotica Cuv., as noticed by me in a specimen collected by Canon Tristram in the same lake. But these eggs, produced by fishes of the size of our common Perch, are very numerous, and measure only about 2 millim. in diameter. It has besides been observed in these Tilapia, as well as in the Siluroids, that the function of protecting the eggs devolves on the male sex, while, to my surprise, the langanyika fish proved on autopsy to be a female. Whether this is constantly so, or whether either parent takes to the nursing duties, remains to be ascertained by examination of a larger number of specimens. I am all the more disposed to think the latter possibility will be confirmed, from the fact that a specimen of Tilapia nilotica

1 The absolutely largest known Teleostean egg is that of the Siluroid Arius commersonii, which measures 17 millim. in diameter. The size of the Arius-egg is much underrated by Günther ('Study of Fishes,' p. 160) and by McIntosh and Masterman ('British Marine Food Fishes,' p. 12), who ascribe to it a maximum of 10 millim. 
with the pharynx filled with embryos belongs to the female sex, while Dr. Lortet's observations on $T$. simonis had led to the belief that specimens carrying eggs in that manner are invariably males.

It is here necessary to recall the observation contained in Livingstone's 'Last Journals,' vol. ii. p. 17, that the "Dagala" or "Nsipé," of Lake Tanganyika, a small fish 2 or 3 inches long, and very like Whitebait, is said to emit eggs by the mouth. The comparison of this fish to Whitebait excludes the possibility of the one here described being the "Dagala" or "Nsipé," which will probably prove to be a Cyprinodont, if not actually the Haplochilus tanganicanus described helow.

\section{Simochromis, g. n.}

Body moderately elongate; scales ctenoid. Jaws with broad bands of minute tricuspid teeth, with an outer series of larger bicuspid teeth, and a single series of conical teeth at the sides of the præmaxillary; maxillary concealed under the præorbital. Dorsal with 17 or 18 spines, anal with 3. Vertebræ 31-32 $(15+16-17)$.

The type species differs from the other members of the genus to which it was originally referred in the differentiation of the teeth at the sides of the præmaxillary, a character in which it agrees with the genus Tropheus.

\section{Simochromis diagramma Gthr.}

Chromis diagramma Günth. Proc. Zool. Soc. 1893, p. 632, pl. lviii. fig. 3.

The bands of teeth in both jaws consisting of 8 to 10 series, gradually decreasing in size from the outer border. Depth of body $2 \frac{1}{2}$ to $2 \frac{2}{3}$ times in total length, length of head $3 \frac{1}{4}$ to $3 \frac{1}{2}$. Snout descending in a strong curve; diameter of eye 3 to $3 \frac{1}{2}$ times in length of bead, $1 \frac{1}{2}$ in interorbital width; mouth extending to below anterior border of eye; 4 series of scales on the cheek; large scales on the opercle. Gill-rakers short, 12 or 13 on lower part of anterior arch. Dorsal XVII-XVIII 9-10; spines increasing in length to the sixth, which measures $\frac{2}{5}$ to $\frac{1}{2}$ length of head; longest soft rays about $\frac{2}{3}$ length of head. Pectoral as long as head. Ventral reaching vent or origin of anal. Anal III 7-8; third spine longest, as long as longest dorsal. Caudal truncate. Caudal peduncle as long as deep. Scales $31-33 \frac{3}{10}$; lat. 1. $\frac{20-23}{10-14}$. Olive, whitish beneath; young with 9 rather indistinct vertical bars; gill-membrane sometimes with dark brown spots; fins greyish; a dark brown stripe may be present along the spinous dorsal, which has a black edge.

Total length 105 millim.

Four specimens from Kinyamkolo. 


\section{Petrochromis, g. $n$.}

Body moderately elongate; scales ctenoid. Jaws with very broad bands of minute, bristle-like teeth, with incurved bi- or tricuspid crowns; maxillary concealed under the præorbital. Dorsal with 17 or 18 spines, anal with 3. Vertebræ $32(16+16)$.

Distinguished from Tilapia by the rery broad bands of minute teeth with incurved crowns, from Simochromis by the absence of conical teeth in the præmaxillary.

21. Petrochromis polyodon, sp. n. (Plate VI. fig. 1.)

Crowns of teeth brown. Depth of body $2 \frac{1}{2}$ to $2 \frac{2}{3}$ times in total length, length of head $2 \frac{3}{4}$ to 3 times. Snout with convex upper profile, $1 \frac{1}{2}$ to $1 \frac{2}{3}$ diameter of eye, which is 4 to $4 \frac{1}{2}$ times in length of head and $1 \frac{1}{2}$ in interorbital width; mouth hardly extending to below anterior border of eye ; 4 or 5 series of scales on the cheek; large scales on the opercle. Gill-rakers very short, 12 or 13 on lower part of anterior arch. Dorsal XVII-XVIII 8-9; spines increasing in length to the sixth or seventh, which measures about $\frac{2}{5}$ length of head; longest soft rays $\frac{3}{5}$ to $\frac{2}{3}$ length of head. Pectoral nearly as long as head. Ventral reaching vent or origin of anal. Anal III 7-8; third spine longest, as long as longest dorsal. Caudal truncate. Caudal peduncle as long as deep. Scales $32-34 \frac{3-4}{12-13}$; lat. 1. $\frac{22-24}{13-17}$. Olive-brown, whitish beneath ; fins grey or blackish.

Total length 135 millim.

Two specimens from Kinyamkolo, and two from Mbity Rocks.

The præmaxillary and mandibular bones are very massive, and the maxillary is much reduced in size; the ascending processes of the præmaxillaries extend to between the anterior borders of the orbits and are received in a deep excavation, to which the strong occipital crest extends; the parietal crests are produced forwards as far as the frontals; the præorbital is large, and the chain of suborbitals very slender. Only the first rib is absolutely sessile, the following being attached to the back of the transverse processes at a short distance from the centre; the epipleurals extend to the twelfth rib; the last two præcaudal vertebræ form a hæmal bridge.

\section{Perissodus, g. $\mathbf{n}$.}

Body elongate; scales cycloid. Teeth rather large, unequal in size, few, with swollen bases and low slightly-notched crowns, compressed transversely to the axis of the jaws, disposed in a single series; maxillary exposed. Dorsal with 18 spines, anal with 3. Vertebræ $35(17+18)$.

The extraordinary dentition which characterizes this new genus may be looked upon as an extreme specialization of that exhibited by Tilapia, a specialization in an opposite direction from that attained by Petrochromis. 


\section{Perissodus microlepis, sp. n. (Plate VI. fig. 2.)}

10 teeth on each side of the præmaxillary, 9 on each side of the mandible. Depth of body $3 \frac{2}{3}$ times in total length, length of head $3 \frac{1}{4}$. Snout a little longer than diameter of eye, which is 4 times in length of head, and almost equals interorbital width; lower jaw projecting; maxillary extending to below anterior border of eye ; 3 series of scales on the cheek; large scales on the opercle. Gill-rakers rather long, 14 on lower part of anterior arch. Dorsal XVIII 10 ; spines increasing in length to the last, which measures $\frac{2}{5}$ length of head; longest soft rays $\frac{2}{3}$ length of head. Pectoral $\frac{3}{4}$ length of head. Ventral not reaching vent. Anal III 8 ; third spine longest, nearly as long as longest dorsal ; longest soft rays half length of head. Caudal truncate. Caudal peduncle $1 \frac{1}{2}$ as long as deep. Scales $65 \frac{5}{20}$; lat. 1. $\frac{44}{30-31}$. Uniform dark reddish brown; a blackish opercular spot.

'Total length 100 millim.

A single specimen from Mbity Rocks ${ }^{1}$.

1 I think it desirable to allude here briefly to two remarkable genera of Cichlidlo from Lake Tanganyika, which I have founded on specimens obtained by Capt. Descamps and scnt to me for study by the Administration of the Congo Free State. The specimens are in so bad a condition that it will never be possible to draw up from them complete definitions of the species, but their dentitions, which indicate remarkable new genera, are well preserved, and I am sure the annexed figurcs together with the short notes here given will be sufficient to ensure their future recognition :-

Ecrodus, g. n.-Teeth very small, conical, in two series in both jaws, the outer larger; outer mandibular teeth pointing outward, perpendicular to the others; maxillary concealed under the præorbital when the mouth is closed. Scales rather large, ctenoid. Dorsal with 14 spines, anal with 3.

Ectodus descampsi, sp. n. (Fig. 1, a.)-D. XIV 14; A. III 8. Depth of body $3 \frac{4}{5}$ times in total length, length of head 3 . Eye very large, $2 \frac{4}{5}$ in length of head, $1 \frac{3}{4}$ interorbital width. Two series of scales on the cheek. Sc. $34 \frac{3}{10}$; lat. 1. $\frac{28}{15}$. Total length 95 millim.

Ectodus melanogenys, sp. n. (Fig. 1,b.)-D. XIV 16; A. III 13. Depth of body 5 times in total length,

Fig. 1.

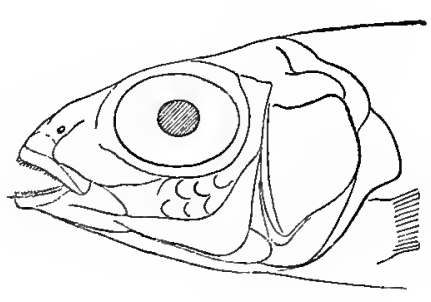

$a$.

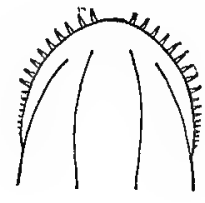

$b^{\prime}$.

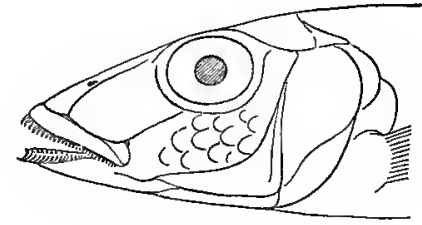

$b$.

length of head $3 \frac{1}{3}$. Eye 4 times in length of head, $1 \frac{1}{2}$ in length of snout, $1 \frac{1}{4}$ interorbital width. Three series of scales on the cheek. About 35 scales in a longitudinal series. A black spot on the chin. Total length 95 millim. 


\section{A S T A C E M BELI D \&.}

23. Mastacembelus mooriI, sp. n. (Plate VII. fig. 1.)

Depth of body 14 times in total length, length of head (without rostral appendage) $6 \frac{1}{3}$ times; vent equally distant from end of snout and base of caudal; length of head $2 \frac{1}{2}$ to 3 times in its distance from vent, and $\frac{1}{2}$ in its distance from first dorsal spine. Snout 3 times as long as eye, ending in a trifid dermal appendage which is a little longer than eye; cleft of mouth extending to below centre of eye; no præopercular spines. Vertical fins united with the rounded caudal. Dorsal XXV-XXVII 70-80 ; spines very short. Anal II 70-80. Pectoral $\frac{1}{4}$ length of head. Scales very small, 30-35 between origin of soft dorsal and lateral line. Brown, tail with a wide-meshed blackish network; dorsal and anal whitish, with a vertical series of blackish spots or vertical bars; anal and caudal edged with blackish.

Total length 440 millim.

Two specimens from Mbity Rocks.

This species has been compared with M. marmoratus, Perugia, from the Congo, which differs in the more slender body (its depth contained 20 times in the total length) with larger scales, the shorter tail, the longer rostral appendage (measuring twice the diameter of the eye), and the higher number (30) of dorsal spines.

I think as many as 13 African species of Mastacembelus may be distinguished, as shown in the following synopsis:-

Plecodvs, g. n.-Teeth large and few, in a single series, dilated at the base, truncated at the end, compressed, slightly grooved in front, curved and directed backwards; 14 teeth in the upper jaw, 12 in the lower; maxillary exposed. Scales moderate, cycloid. Dorsal with 19 spines, anal with 3.

Fig. 2.
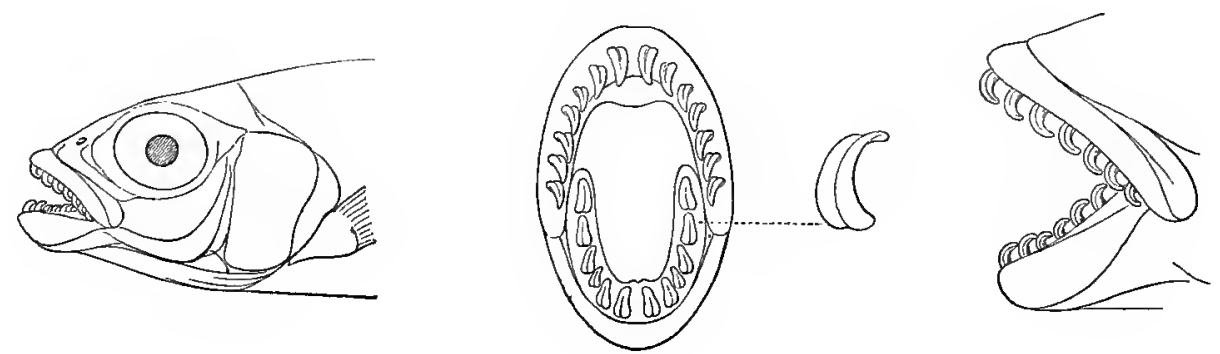

Flecodus paradoxus, sp. ฉ. (Fig. 2.)-D. XIX 14 ; anal III 12. Depth of body 4 times in total length, length of head $4 \frac{1}{2}$. Eye large, longer than snout, $\frac{1}{3}$ length of bead, $1 \frac{1}{4}$ interorbital width ; maxillary extending to below anterior third of eye; 3 series of scales on the cheek. Sc. $65 \frac{6}{17}$; lat. $1 . \frac{50}{40}$. Total length 90 millim. 
I. Vent nearly equally distant from the end of the snout and the base of the caudal fin.

A. Two strong præopercular spines.

D. XXIII-XXIV 75; A. Il 75-76; length of head (measured to extremity of opercle and without rostral appendage) hardly twice in its distance from vent and 6 times as great as its distance from the first dorsal spine . . . . . . . . . 1. M. marchii Sauv.

D. XXIV 100 ; A. II 100 ; length of head $3 \frac{1}{2}$ times in its distance from vent, equal to its distance from the first dorsal spine . . . . . . . . . . . 2. M. cryptacanthus Gthr.

D. XXVII 85 ; A. III 92 ; length of head $2 \frac{1}{2}$ in its distance from vent, 3 times as great as its distance from first dorsal spine . . . . . . . . . 3. M. congicus Blgr. ${ }^{1}$

D. XXVI-XXX 80 ; A. II 80 . . . . . . . . . . 4. M. liberiensis Blgr. ${ }^{2}$

D. XXIX-XXX 117-130; A. II 117-127; length of head nearly 4 times in its distance from vent, and nearly twicc as great as its distance from the first dorsal spine.

B. Præopercular spines minute (young) or absent.

5. M. loennbergii Blgr. ${ }^{3}$

D. XXVII-XXVIII 70-80; A. II 80-90; length of head 3 to 4 times in its distance from vent, equal to or a little less than its distance from the first dorsal spine.

6. M. flavomarginatus Blgr."

D. XXVII 80-82 ; A. II 60-65; length of head equal to its distance from the first dorsal spine.

7. M. niger Sauv.

D. XXVII-XXIX 65-70; A. II 68-75; length of head $2 \frac{1}{2}$ to 3 times in its distance from the vent, and $\frac{1}{2}$ in its distance from the first dorsal spine. . . 8. M. shiranus Gthr.

D. XXIX 95 ; A. II 85 ; length of head 3 times in its distance from the vent, and $\frac{1}{3}$ in its distance from the first dorsal spine . . . . . . . . . . 9. M. nigromarginatus Blgr. ${ }^{5}$

D. XXV-XXVII 70-80; A. II 70-80; length of head twice in its distance from the vent, and nearly $\frac{1}{3}$ in its distance from the first dorsal spine. . . . 10. M. moorii Blgr.

II. Vent much nearer the caudal fin than the end of the snout; one or two præopercular spines.

D. XXX 85 ; A. II 70 . . . . . . . . . . . . . 11. M. marmoratus Perugia."

D. XXXIII-XXXV 50-60; A. II 50-60 . . . . . . . . 12. M. tanganice Gthr.

III. Vent much nearer the end of the snout than the caudal fin.

D. XXXI-XXXII 103 ; A. I 116 . . . . . . . . 13. M. ophidium Gthr.

1 A species from the Upper Congo founded on a single specimen with mutilated tail and regenerated caudal fin. I have now a perfect specimen.

${ }^{2}$ M. marchii Steind. nec Sauv.-Liberia.

${ }^{3} M$. cryptacanthus Loennberg nec Gthr.-Cameroon.

4 A new species founded on specimens from the Gaboon previously referred to M. cryptacanthus.

A new species founded on a single specimen from Ashantee.

- Type examined.-Vent equally distant from the head and from the caudal; head once and a hali ns luug as its distance from the first dorsal spine; 17 scales between origin of soft dorsal and lateral line. 
24. Clarias anguiluaris I.

\section{S I L U R I D XE.}

This species occurs in the Nile as well as in the Niger and the Ogowe. It is one of those Siluroids which are known to live a considerable time out of water and to make excursions on dry land after the manner of Eels.

25. Clakias liocephalus, sp. n. (Plate VII. fig. 2.)

Vomerine teeth in a narrow band, without posterior process. Depth of body $5 \frac{1}{2}$ times in total length, length of head 5 times. Head smooth, covered with soft skin, slightly longer than broad; occipital process very short, angular; diameter of eye 3 times in length of snout, 6 times in interorbital width; maxillary barbel as long as the head, nasal barbel a little shorter; inner mandibular barbel $\frac{3}{5}$ length of head. Dorsal 70. Anal 50. Caudal free. Pectoral $\frac{1}{2}$ length of head, not extending to the vertical of origin of dorsal fin. Uniform blackish brown.

Total length 80 millim.

A single specimen from Kinyamkolo.

\section{Anoplopterus Platychir Gthr.}

Two specimens from marshes near Mbity.

I have recently recorded the occurrence of this species in Lake Nyassa, and it bas also been described by Vaillant as Chimarrhoglanis leroyi, from Mrogoro torrent, Urugaru Mountains, East Africa.

\section{Auchenaspis biscutata Geoffr.}

Known from the Nile and the Senegal.

\section{Synodontis multipunctatus, sp. n. (Plate VIII.)}

Præmaxillary teeth in 5 or 6 irregular transverse series; mandibular teeth in a single series of 16, feebly curved, simple, measuring hardly $\frac{1}{3}$ diameter of eye. Depth of body $3 \frac{1}{4}$ times in total length, length of head $3 \frac{2}{3}$. Head scarcely longer than broad, slightly convex on the crown; snout rounded, less than half length of head, twice as long as eye; eye supero-lateral, well visible from above, its diameter $4 \frac{1}{2}$ times in length of head, twice in interorbital width. Gill-cleft very narrow, not extending below base of pectoral. Maxillary barbel simple, reaching a little beyond anterior third of pectoral spine; mandibular barbels strongly fringed, outer a little more than twice as long as inner, and half as long as maxillaries. Dorsal II 7 ; spine strong, a little shorter than the head, strongly serrated behind in its distal half. Adipose fin low, a little shorter than the head, twice as long as its distance from the dorsal. Humeral process simply granulate, sharply pointed, not 
extending quite so far as the occipito-nuchal shield, which is $1 \frac{1}{2}$ as long as broad and reaches the first soft ray of the dorsal. Anal III 7. Caudal deeply bifurcate. Skin smooth. Pale reddish brown above, with very numerous blackish-brown round spots, which are smallest on the head and nape; lower parts and barbels white, unspotted; ventrals yellow; dorsal and caudal broadly edged with yellow.

Total length 240 millim.

A single specimen from Sumbu.

29. Malapterurus electricus Gm.

The Electric Cat-fish is widely distributed, being on record from the Nile, the Niger, the Ogowe, and the Congo.

30. LaBEo, sp. inc.

\section{Y PRINID $F$.}

An unmistakable figure of a Labeo is among Mr. Moore's sketches, and although the specimen is not represented in the collection entrusted to me for description, I have included the fish as being the only representative of the Cyprinoids yet found in Tanganyika. The specimen from which the drawing was made was of large size, and therefore could not be preserved under the difficult circumstances to which allusion has been made in the introduction to this memoir.

\section{H A R A C I N I D}

\section{Alestes MaCrolepidotus C. \& V.}

Occurs in the Nile, the Senegal, the Niger, and the Congo.

32. Alestes macrophthalmus Gthr.

This fish was known only from the Ogowe.

33. Hydrocyon Forskali Cuv.

Occurs in the Nile, the Senegal, and the Niger.

\section{CYPRINODONTID A.}

34. Haplochilus tanganicants, sp. n. (Plate VI. fig. 3.)

Body compressed, its depth 4 times in total length; length of head $4 \frac{1}{3}$ times. Snout depressed; lower jaw projecting beyond the upper; eye a little longer than snout, a little shorter than interorbital width, 3 times in length of head. Dorsal 13, originating at equal distance from the head and the caudal fin; the first ray corresponds to the 18th scale of the lateral line; posterior rays longest, $\frac{2}{3}$ length of head. Anal 28 , ariginating below extremity of pectoral. Pectoral $\frac{4}{5}$ length of head, extending far beyond root of ventral. Caudal feebly emarginate. Candal peduncle twice as long as VOL. XV.-PART I. No. 4.-December, 1898. 
deep. Scales 42 in a longitudinal line, 11 in a transverse line. Silvery, with a darker lateral stripe; dorsal and anal with greyish horizontal streaks.

Total length 80 millim.

A single specimen from Mbity Rocks.

$$
\text { P OLYPTERIDE. }
$$

35. Polypthrus bichir Geoffr. (?).

Mr. Moore informs me that a Polypterus occurs in moderate abundance in the lake, and although he did not bring home specimens, he feels tolerably confident, from his recollection of them, that the fish belongs to the typical $P$. bichir, which occurs in the Nile, the Niger, and the Congo, and not to any of the closely-allied species that are often confounded with it.

\section{APPENDIX. By J. E. S. Moore.}

In the foregoing description of the fishes which I succeeded in bringing through from Tanganyika to the coast, Mr. Boulenger has already alluded to the difficulties that were experienced in transporting them in spirit, through several hundred miles of often trackless, always scorching, forest, and of the inevitable losses which this entailed. The difficulties of transport, however, were by no means all. It must be nearly impossible for anyone who has not visited the African lakes to realize their huge size and oceanic character.

One must be as heavily equipped for dredging in these waters as would be required for effective operations in the open sea. It will easily be understood, therefore, how incomplete our knowledge of the deep-water fauna of these lakes must be considered, when it is remembered that on Tanganyika I was of necessity forced to work with native dug-out boats, and with nothing better than the natives themselves as motive power.

In the case of the fishes, moreover, there are no sources of collateral evidence from which we may obtain any insight into the nature of the deep-water forms, for dead fishes, unlike molluscs, leave no shells behind them, to be thrown upon the beaches of the lake, whereby, in the case of the molluscs, we gain some knowledge of the existence of forms which have not been seen alive; nor can we make use of the knowledge of the inhabitants in this matter, for the best of the Tanganyika natives are but wretched fishermen, merely using either surface traps, or light and inefficient drag-nets, which are thrown out a short distance from the shore and then hauled in to the land. Such nets are necessarily used only on smooth sandy beaches, and consequently the fishes caught in them are only of those $s_{i}$ ecies which inhabit places 
of this description, and although they are numerically abundant, they belong to half a dozen species at the most.

Nearly all the new forms which I obtained were killed by dynamite from the craggy ledges of the west coast of the lake, where the water was deep enough, about 20-35 feet, but not too deep for my men to dive and procure the greater number of the fishes, which, after every shot, were invariably found on the bottom. The number of fishes in such situations is really surprising, and on several occasions, after firing a single cartridge, I obtained more than two tall negroes could well carry, when slung in a bag between them on a pole.

Only one fish was obtained from anything approaching to the deeper water of 'Tanganyika, about 400 feet, which was accidentally entangled in a basket dredge, and this was the specimen of the new species Bathybates ferox described on p. 15 .

Of the fishes which exist on the great mud-plains, which are to be found about 1000 feet below the surface in many portions of the lake, or of those which may occur in the vastly deeper portions, absolutely nothing is known.

The fishes which have been collected, moreover, were obtained almost exclusively from the south-western extremity of 'langanyika, and to suppose that the fishes which occur in this locality are in any way representative of the fishes, even in similar situations, throughout the whole lake, would be as absurd as if we were to suppose that the shoal-water fish of the whole English Channel could be obtained fiom a few miles of rocky beach about the Needles and the Isle of Wight. 'That the fishes differ in different portions of the lake I have myself observed, and it has also been shown in a most striking manner by the fact that of the six species previously described from 'langanyika, which were collected by Captain Hore near Ujiji, I have only rediscovered one.

The fishes which have been already obtained in Tanganyika, or in Nyassa for that matter, must therefore be regarded as merely the surface skimmings of these lakes, and as in no sense representing the whole fish-fauna they may contain.

Really deep water, 300 fathoms and upwards, is to be found over large areas in Nyassa, and to what depth the water in Tanganyika may reach no one knows; but it is obvious that where water of such depth exists, if the lakes in which it is contained have been permanent for any great length of time, there ought to be modified forms of the freshwater fishes to suit such depths, and, with the exception of Bathybates ferox, these have not yet been obtained.

In the case of Tanganyika, the interest which attaches to the future exploration of its deeper water is particularly great, since I have elsewhere shown that the majority of the Halolimnic animals, most of the molluscs, sponges, and so forth, are exclusively deep-water forms. In fact, it was only when my dredging capacities, so to speak; were giving out, that the more interesting of these forms, the genera Typhobia, Bathanalia, and the like, were beginning to come in. 
That there are no Halolimnic representatives anong the fishes which have hitherto been obtained is no evidence that other fishes of a widely different and possibly of a Halolimnic type may not in future be secured. On the other hand, the fact that the Teleostean fishes now existing in Lake Tanganyika should not correspond with the Molluscan section of the Halolimnic group is really what one would expect; for, as I have recently shown ${ }^{1}$, the facies of the Molluscan section of the Halolimnic group is almost, if not quite, indistinguishable from that of the Jurassic seas. Except the Herring-like Leptolepidoe, few, if any, Teleostean fishes are represented in Jurassic beds, and we should therefore expect the piscine accompaniments of the Halolimnic molluscs to be entirely composed of Ganoids and the like. I found a species of Polypterus, which I took to be P. bichir, abundant on the southern shores of Lake Tanganyika, and it is quite possible that some of the active carnivorous fishes which inhabit the open water may be Ganoids too. What the fish is that so much surprised Glaive, when he crossed the lake, by attacking the paddles of his boat, is quite unknown, but I myself saw these same fishes attack the paddles of my own boat, not 20 miles from the spot where Glaive described them, on the west coast of the lake.

Judging, therefore, from the incomplete character of our knowledge of the fishfauna of Lake Tanganyika, and from the vast antiquity of the lake, as evidenced by the Jurassic facies of its molluscan shells, it is only natural to expect that future exploration may reveal, among these fishes, forms that are of the highest scientific interest from a morphological point of view. I mean that Tanganyika and its neighbourhood present one of those few localities where it is legitimate to expect that we may discover many forms that in most places have become extinct.

Our very slight acquaintance with the surface-forms existing in Nyassa and Tanganyika, and the complete absence of all knowledge of the contents of the deep waters of these lakes, unfortunately by no means exhausts the sum of our present ignorance of these matters. We have no real knowledge of the extent of the Halolimnic fauna, beyond the lake in which it was originally discovered. I have shown only that this fauna is not present in Nyassa nor in Shirwa, nor yet even in the little lake Kela, not more than 20 miles from the Tanganyika shore, and that it is extremely probable that it does not extend to Mwero and Lake Bangweolo to the west. But for anything that can actually be shown to the contrary, it may be present in Lake Rukwa to the east, and in the Albert and Albert Edward Nyanzas to the north, and it is perhaps almost to be expected that some representatives of this stock shonld be found in Lake Kivu, which lies in the same great valley not more than 50 miles to the north of Tanganyika. But what is the relation of this lake, the effluent of which flows south into Tanganyika, to the Albert and Albert Edward Nyanzas, with effluents flowing into the Nile, towards the north? All that

' "On the Hypothesis that Lake Tanganyika represents an old Jurassic Sea,' Quart. Journ. Microsc, Sci. xli. no. 162, June 1898. 
we know at present is that the watershed between these lakes is situated in their common valley, and that the whole series of lakes, from Tanganyika in the south to the Albert Edward in the north, appears to lie in one continuous valley-system, which owes its origin to a single geological movement, that has affected, although it may be at very different times, an immense area of ground, and reaches at the present time actually to the shores of the Red Sea.

The lakes which lie in these valleys immediately to the north of Tanganyika are therefore of especial zoological interest, for it may be that in these isolated sheets of water there exist animals analogous to those which constitute the Jurassic Halolimnic fauna of Tanganyika itself. The similarity of the Halolimnic gastropods to those of the Jurassic seas is, as I have insisted elsewhere, so complete and so remarkable that no effort should be spared which may throw light on the real nature and origin of these forms.

The only geographical fact which is at present available is this, that there exists a certain similarity in the fish-fauna of Tanganyika to that of the lower Nile, and it may be that this is an indication that at some time the Nile watershed was further south, and drained out of Tanganyika to the north, in which case Halolimnic animals will without doubt be found among the lakes towards the north. All this is, however, little more than mere conjecture, but it will help my present purpose if it renders more apparent the extreme desirability of becoming better acquainted with the zoology of the lakes in the Rift valleys immediately to the north of Tanganyika.

The presence of a Halolimnic fauna in Lake Tanganyika, as something superadded to the normal freshwater stock of the lake, is at present the central fact, and if the expectations which the morphological characters of those Halolimnic animals already known have raised should be fulfilled, we have something here which may completely change our views respecting the past history of the continent, and provide morphology with some most unique and valuable comparative material.

\section{EXPLANATION OF THE PLATES.}

\section{PLATE I.}

Fig. 1. Lates microlepis, p. 6.

Fig. 2. Lamprologus fusciatus, p. 7.

Fig. 3. " $\quad$ compressiceps, p. T.

Fig. 4. " moorii, p. 8 .

Fig. 5. " modestus, p. 8.

Fig. $6 . \quad$ elongatus, p. 9.

PLATE II.

Fig. 1. Lamprologus furcifer, p. 9.

Fig. 2. Telmatochromis vittatus, p. 10.

YOL. XV.-PART I. No. 5.-December, 1898. 
Fig. 3. Telmatochromis temporalis, p. 11.

Fig. $3 a$. " " , dentition.

Fig. $3 b . \quad$ " $\quad$, skeleton.

Fig. 4. Julidochromis onnatus, p. 12.

Fig. 4 a. " " $\quad$ dentition.

Fig. 4 b. , , skeleton.

PLA'TE III.

Fig. 1. Paratilapia pfefferi, p. 12.

Fig. 2. " macrops, p. 13.

Fig. 3. " $\quad$ ventralis, p. 13.

Fig. 4. $\quad, \quad$ leptosoma, p. 14.

Fig. 5. Eretmodus cyanostictus, p. 16.

Fig. $5 a$. , , , dentition.

Fig. $5 b . \quad, \quad, \quad$ skeleton.

PLATE IV.

Fig. 1. Paratilapia furcifer, p. 14.

Fig. 2. Bathybates ferox, p. 15.

Fig. 2 a. " , " dentition.

PLATE V.

Fig. 1. Tilapia labiata, p. 17.

Fig. 2. Tropheus moorii, p. 18.

Fig. $2 a$. , , , dentition.

Fig. $2 b$. , , , skeleton.

PLATE VI.

Fig. 1. Petrochromis polyodon, p. 20.

Fig. 1 a. " " " dentition.

Fig. 1 b. ", , skeleton.

Fig. 2. Perissodus microlepis, p. 21.

Fig. $2 a . \quad " \quad$ dentition.

Fig. 3. Haplochilus tanganicanus, p. 25.

PLATE VII.

Fig. 1. Mastacembelus moorii, p. 22.

Fig. 2. Clarias liocephalus, p. 24.

Fig. $2 a$. " $\quad$ " upper view of head and nape. Magnified $(\times 3)$.

PLATE VIII.

Synodontis multipunctatus, p. 24, with lower view of head. 


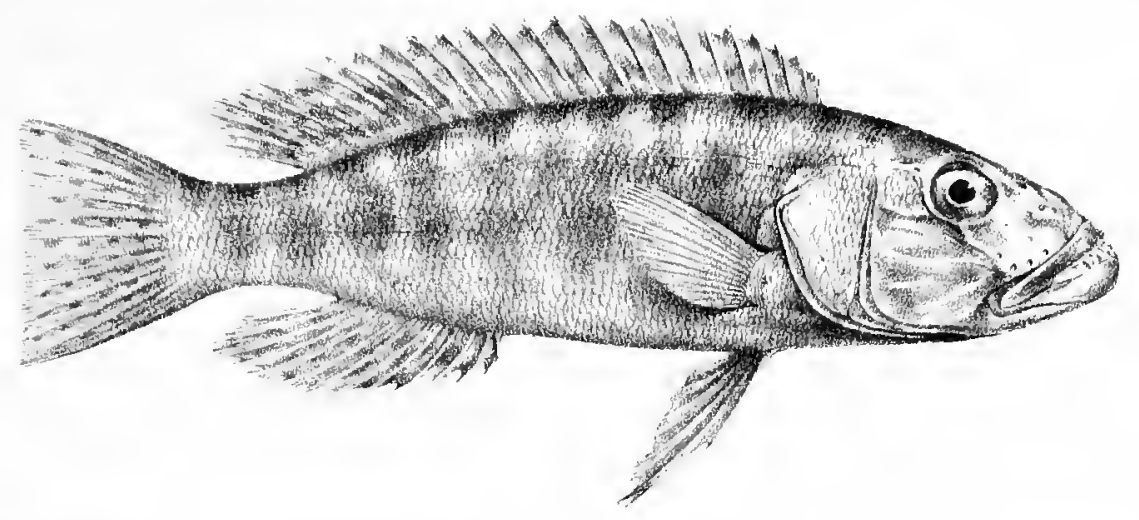

i
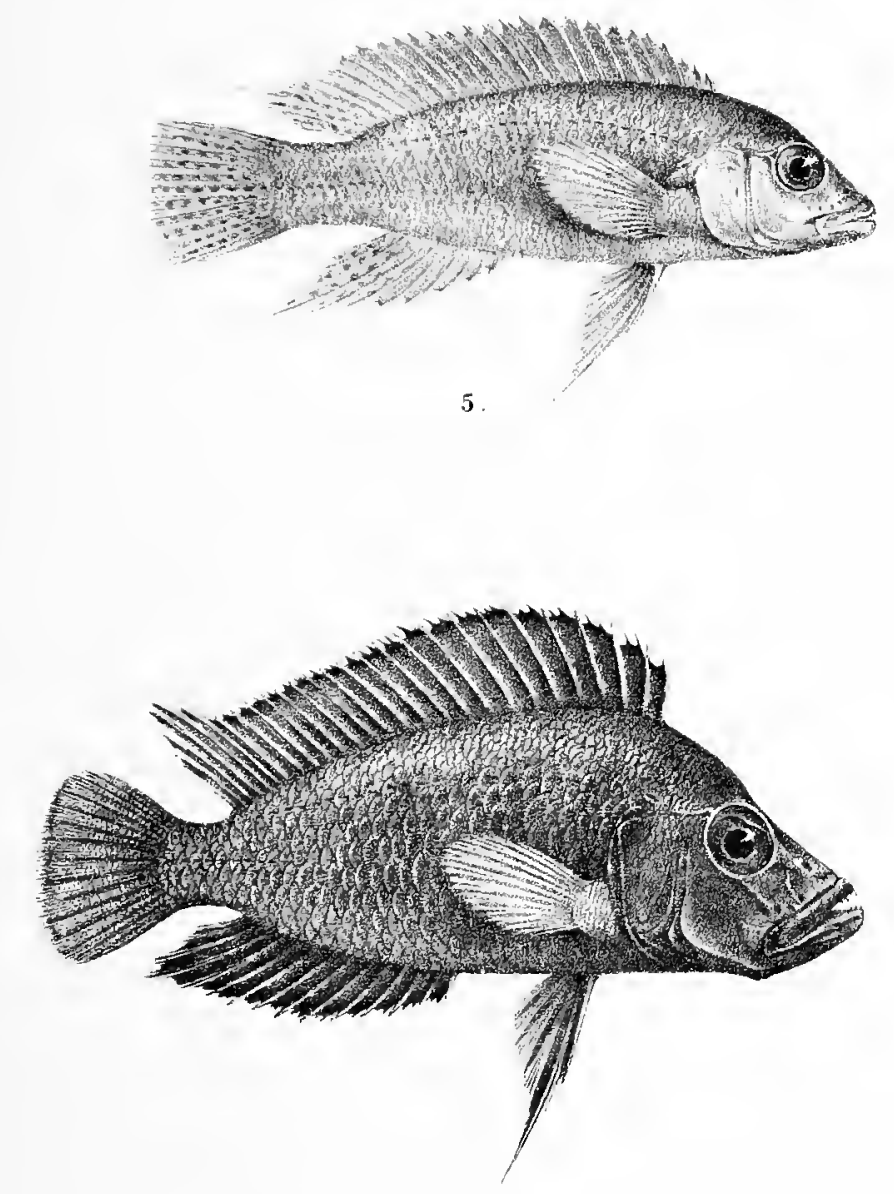

1. LATES MICROLEPIS.

4 LAMPROLOGUS MOORII

2.I

IAIMPROLOGUS FASCIATUS, 3. LAMPROLOGUS COMPRESSICEPS

5. LAMPROLOGUS MODESTUS. 6 IAMFROLOGUS ELONGATUS. 


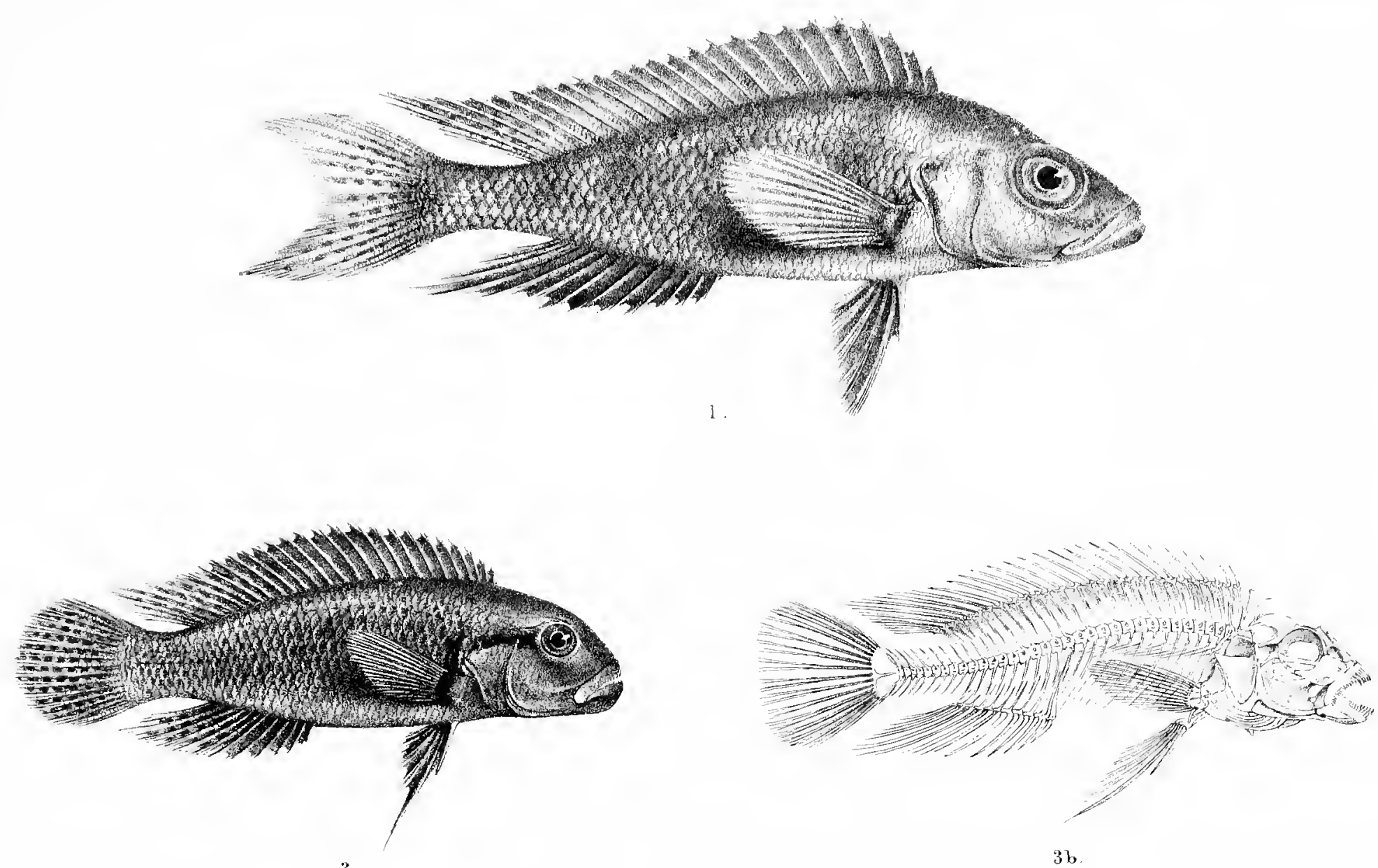

3

$3 \mathrm{~b}$

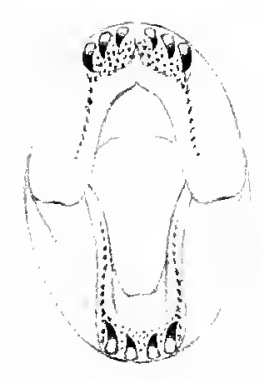

$4 a$

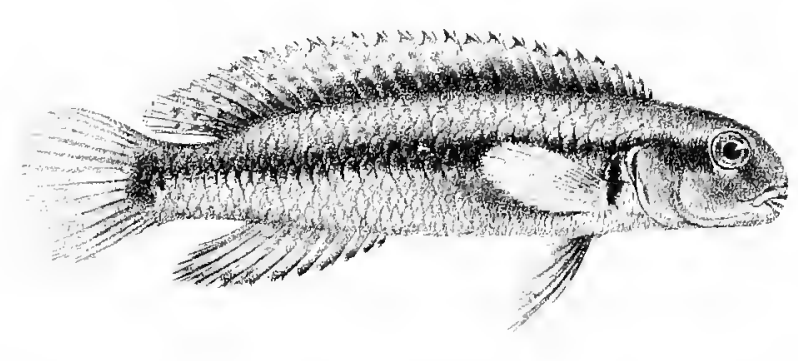

2.

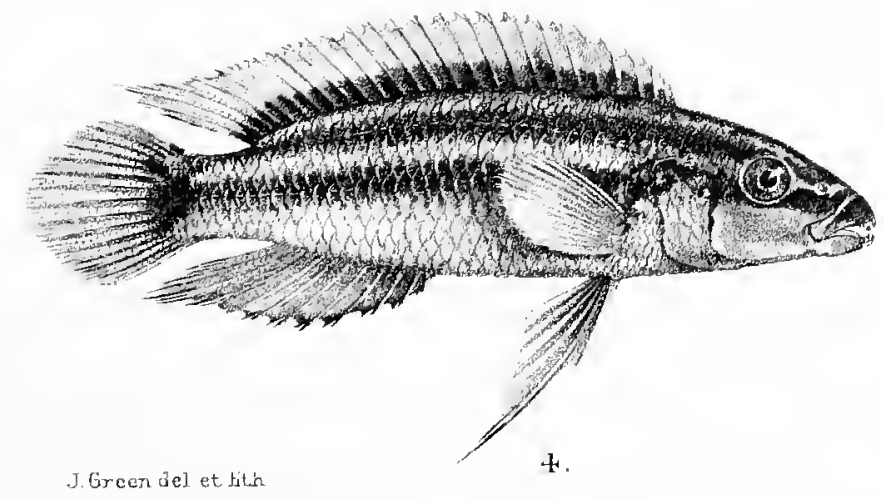

1. LAMPROIOGUS FURCIFER

$\therefore$ TFITMATOCHROMIS TEIMTORALIS.

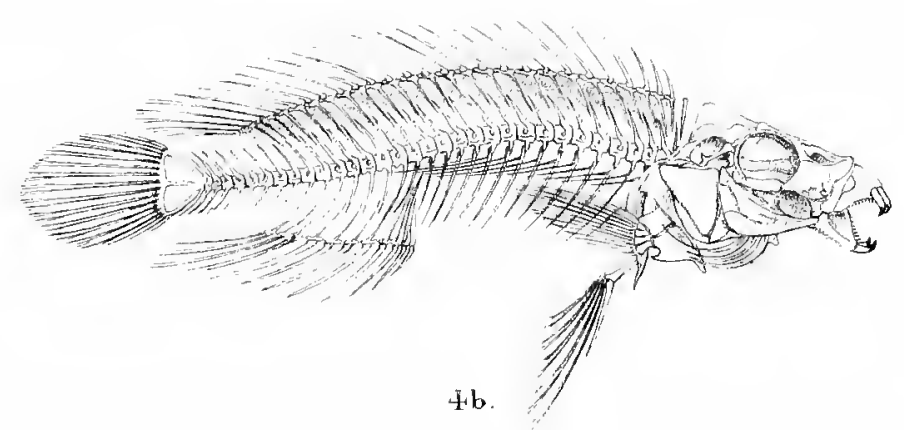

Mintern Brosimp

2.TELMATOCHROMIS VITTATUS.

4. JULIDOCHROMIS ORNAIUS. 



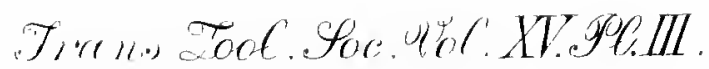
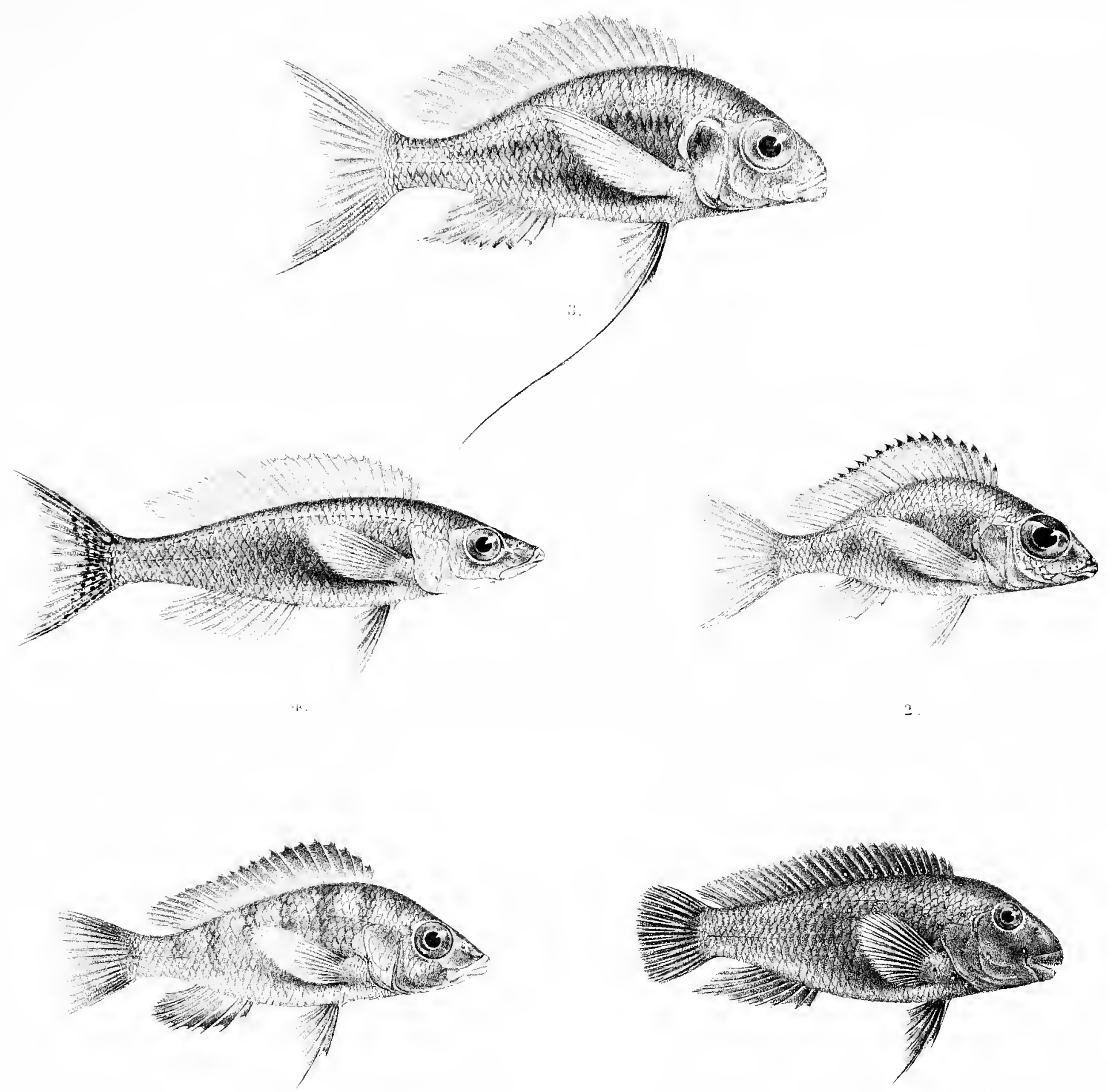

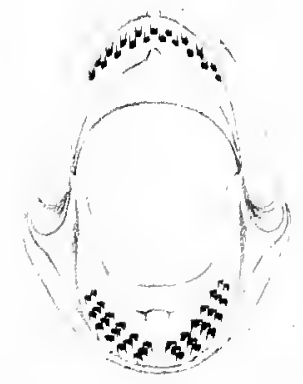

$5 a$
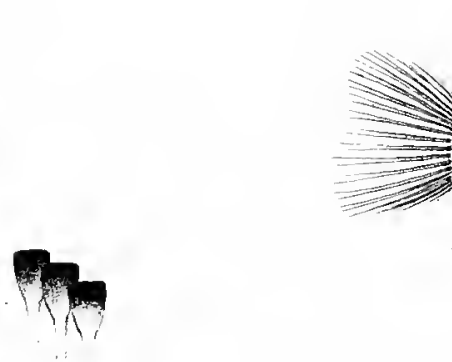

.

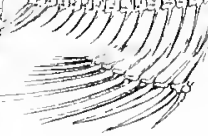

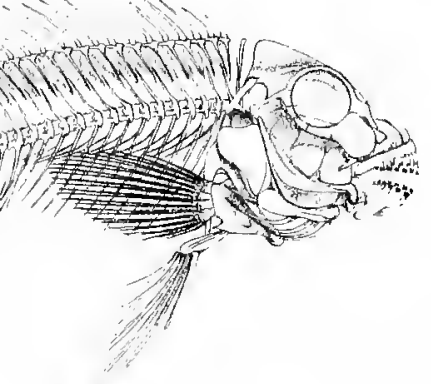

$5 b$. 



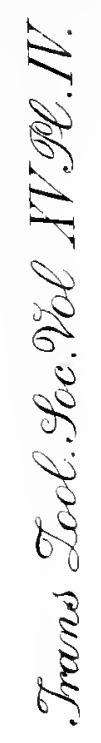
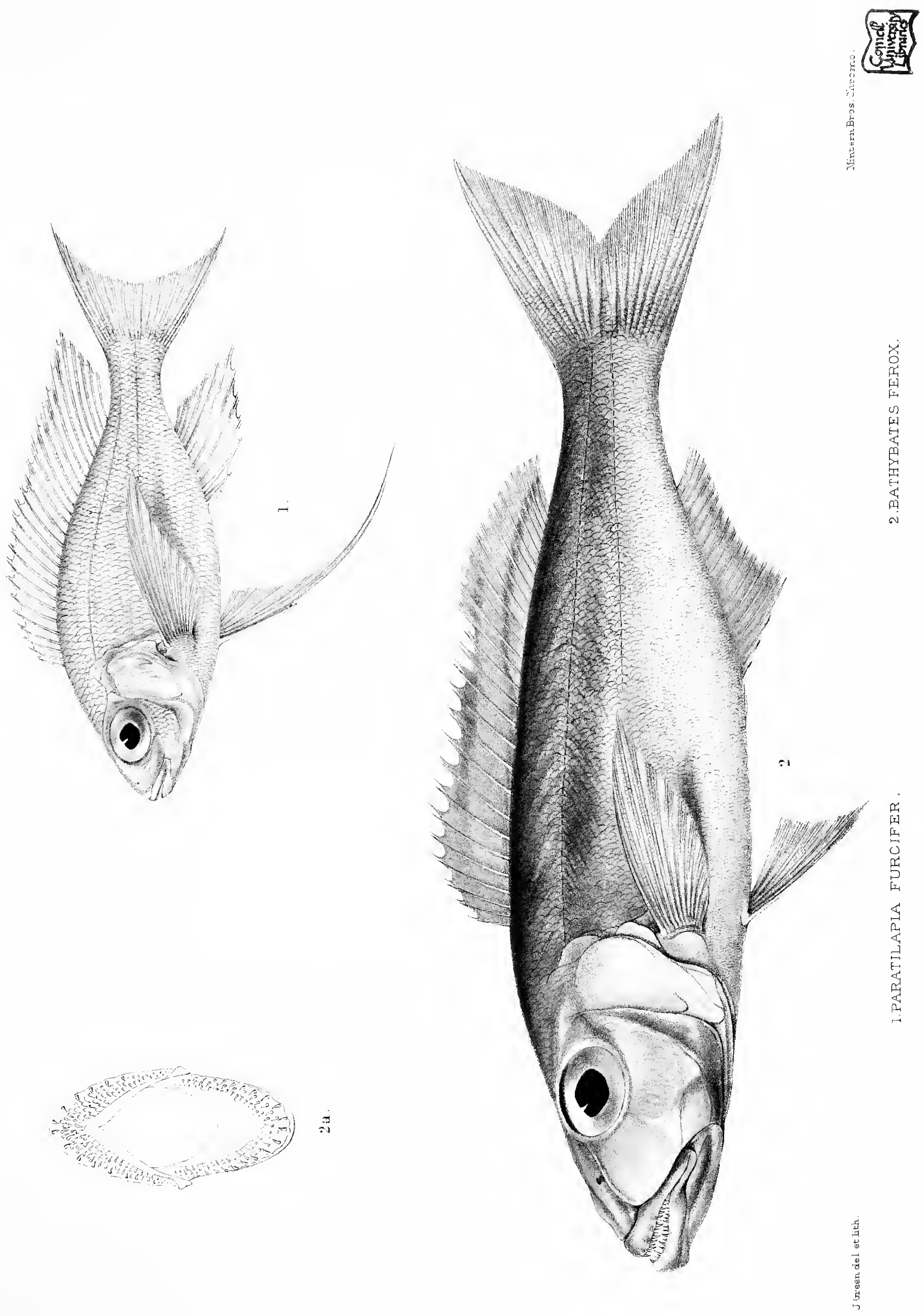



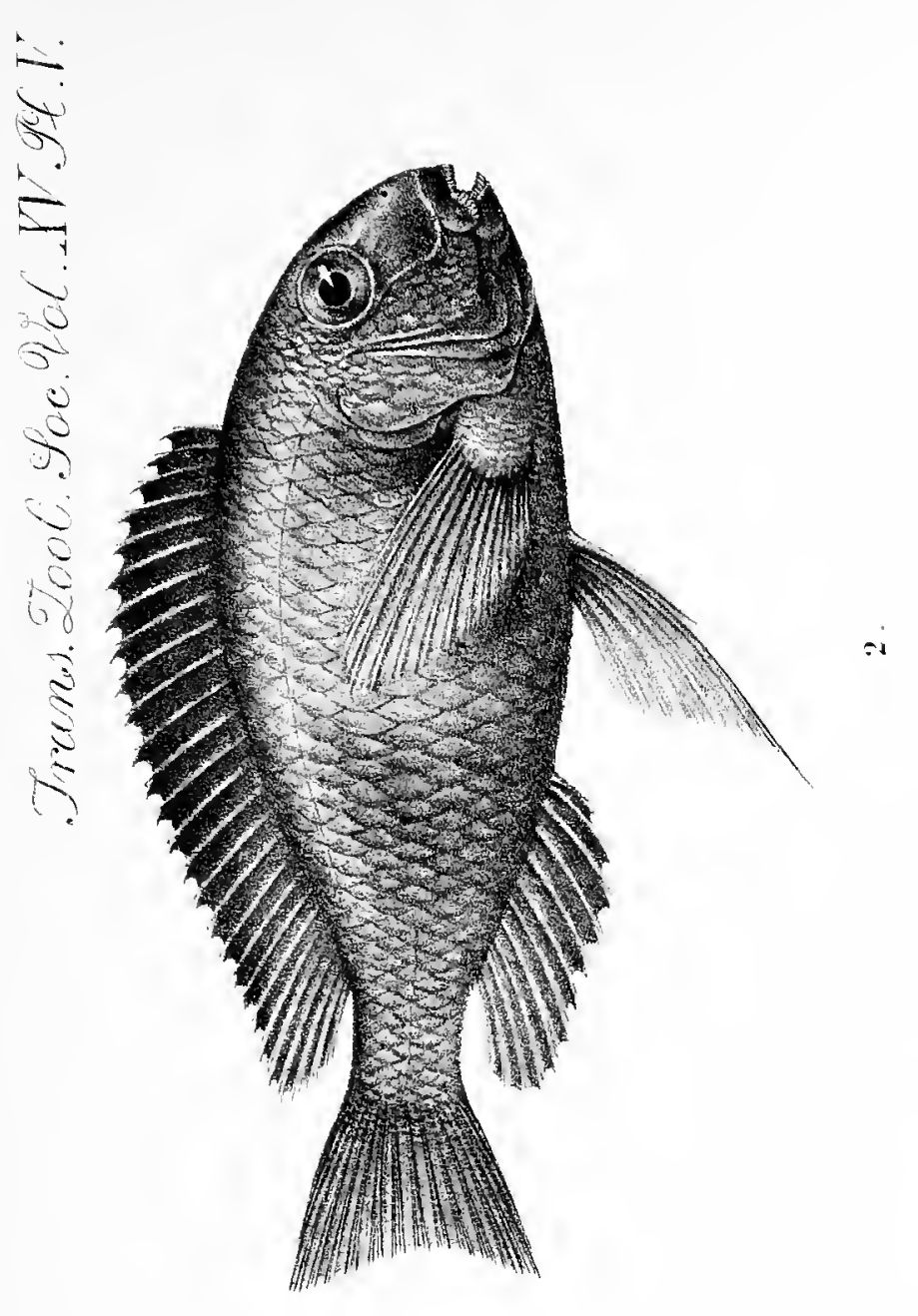

鹳
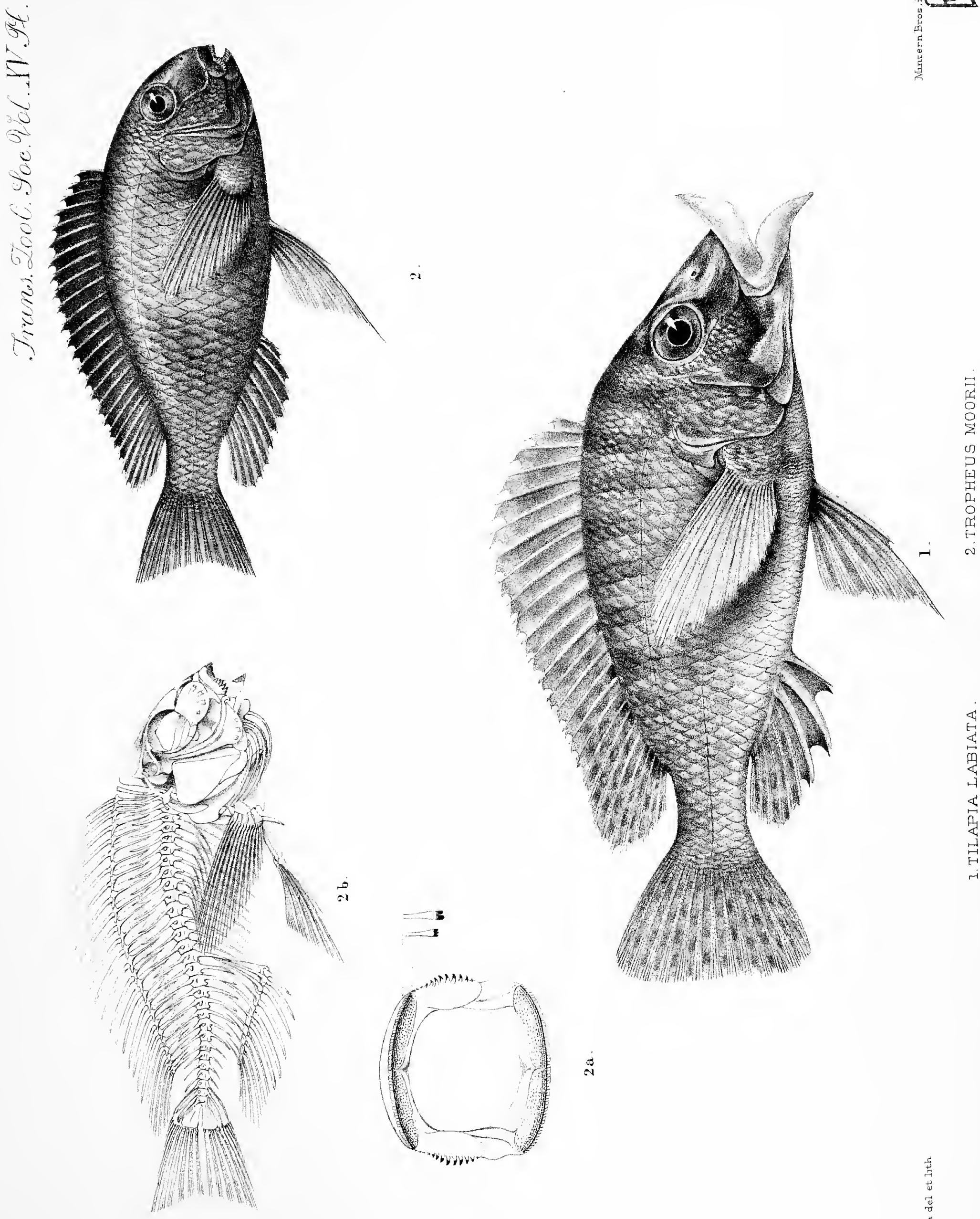

出 


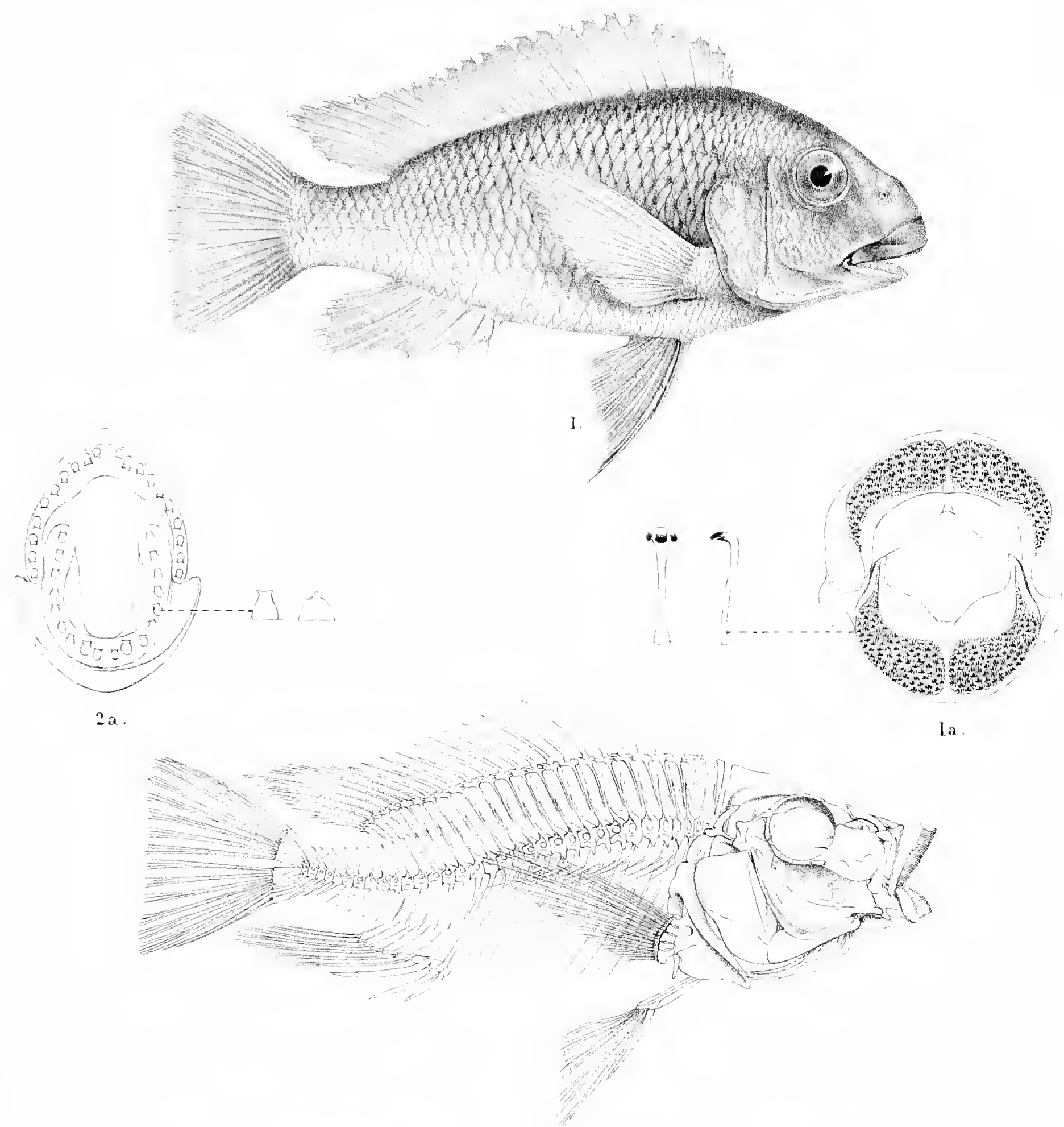

Ib.
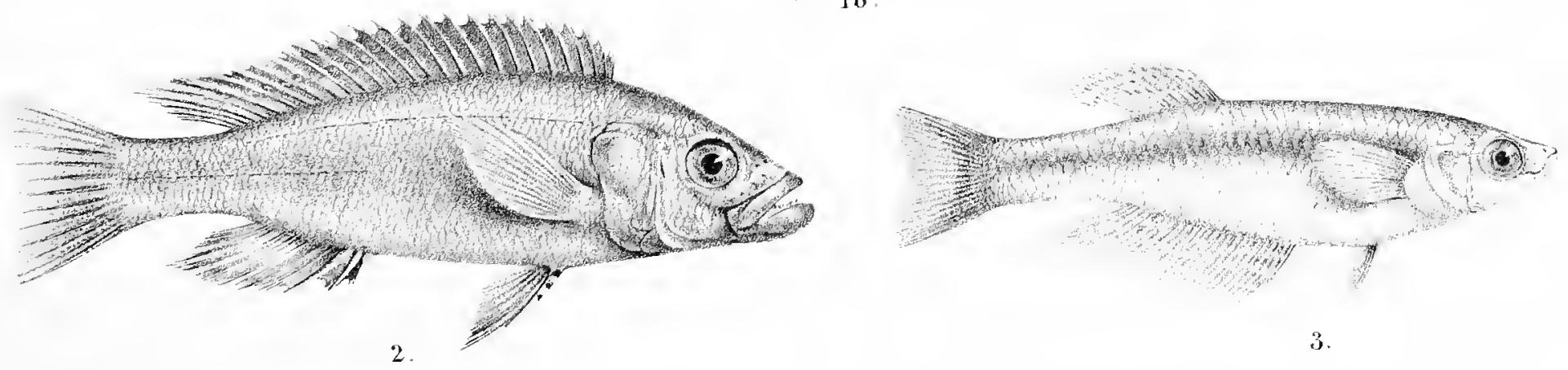

3. 


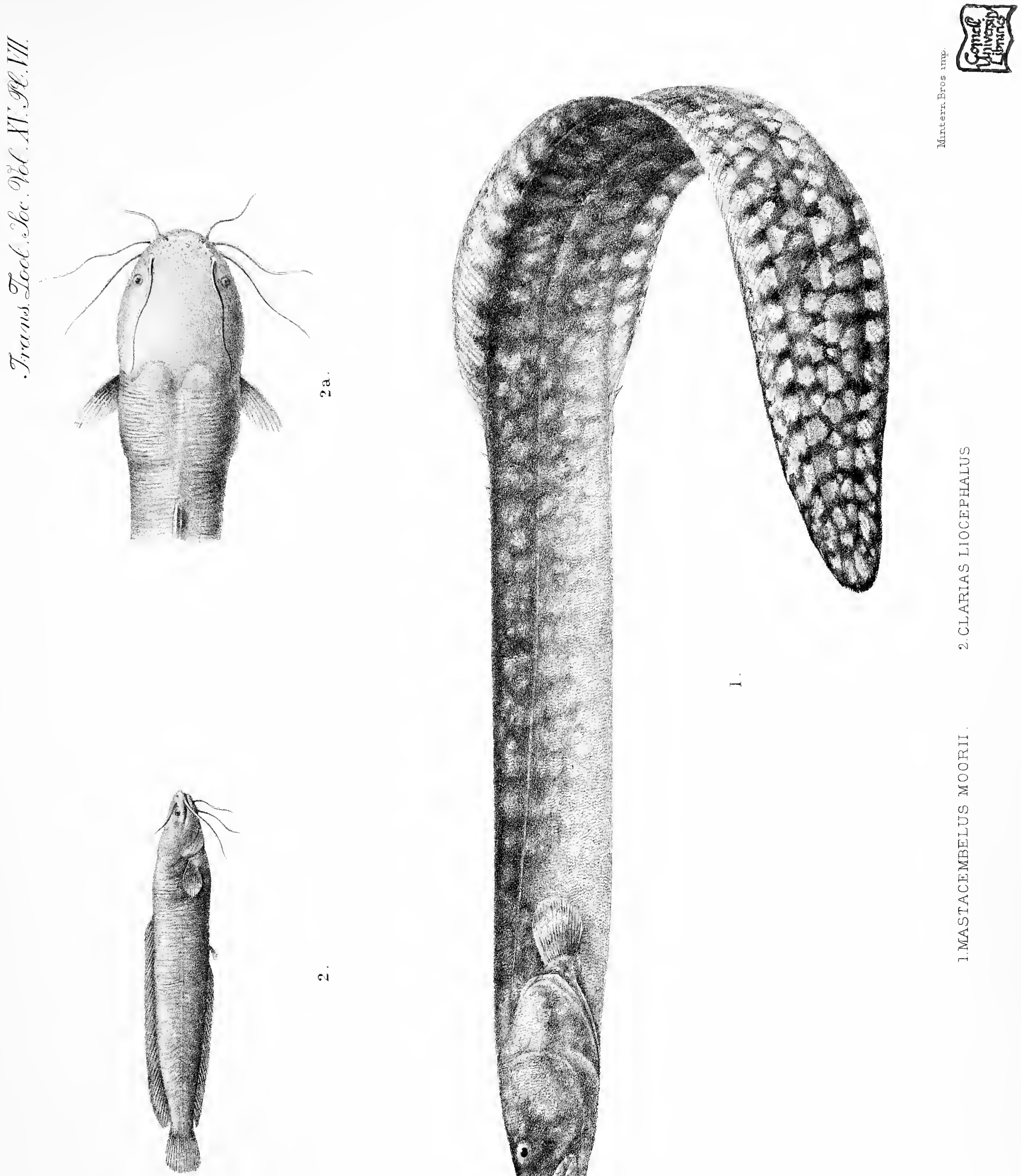

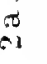

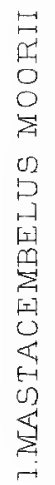

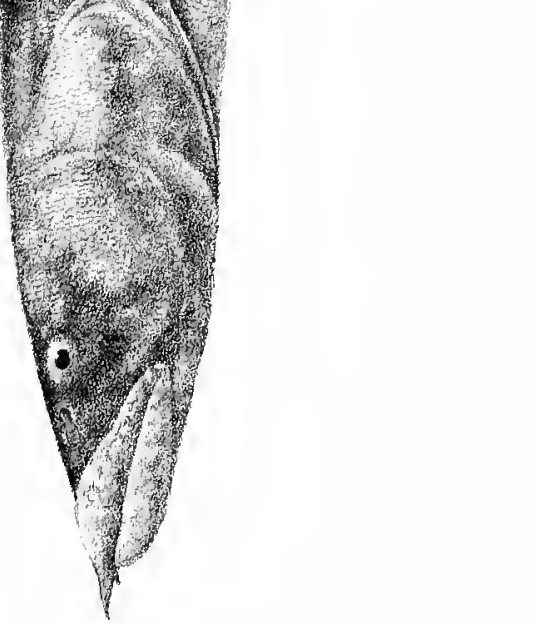

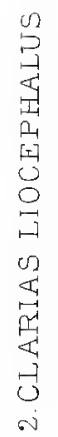





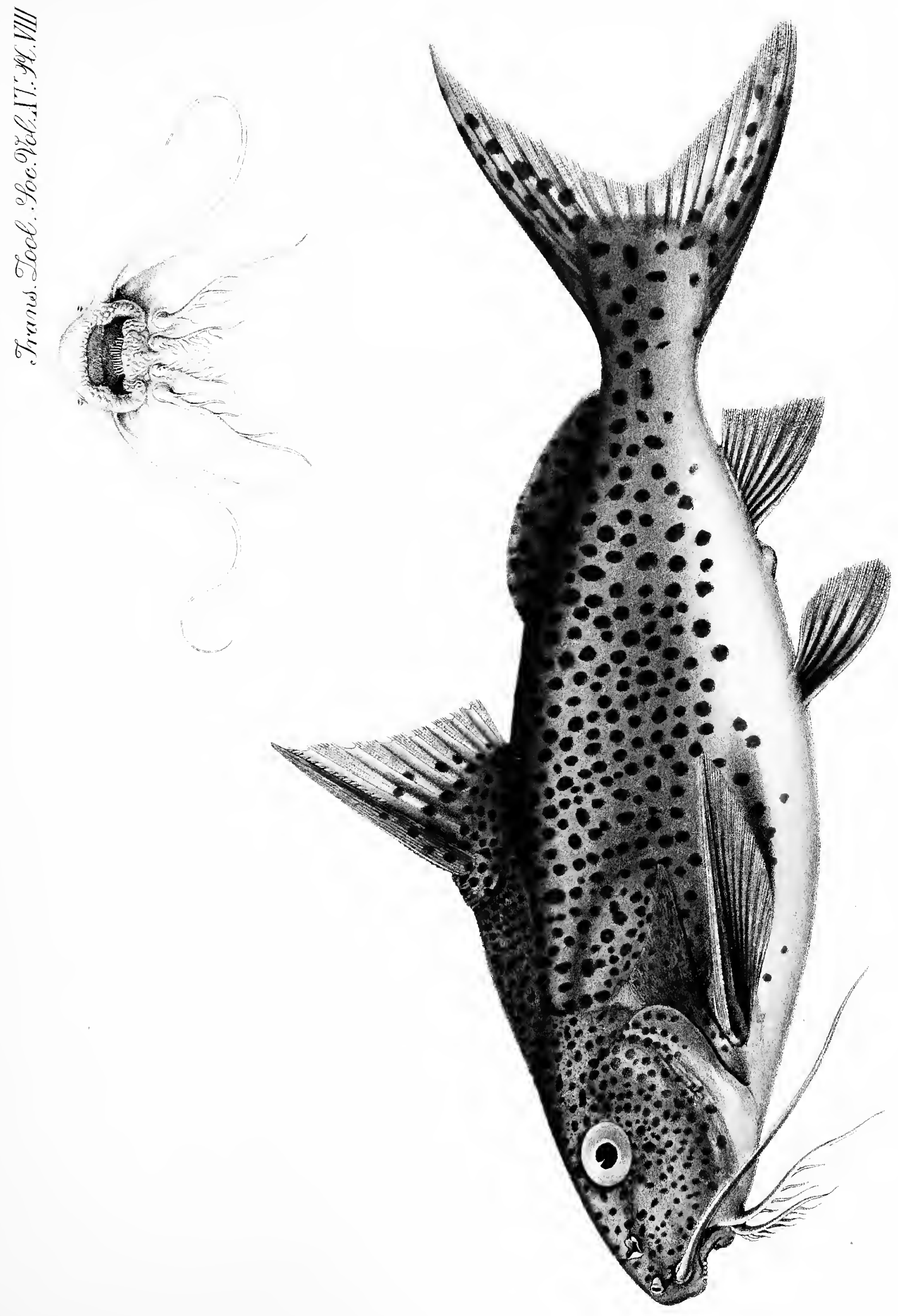





\section{TRANSACTIONS OF THE ZOOLOGICAL SOCIETY OF LONDON (continued).}

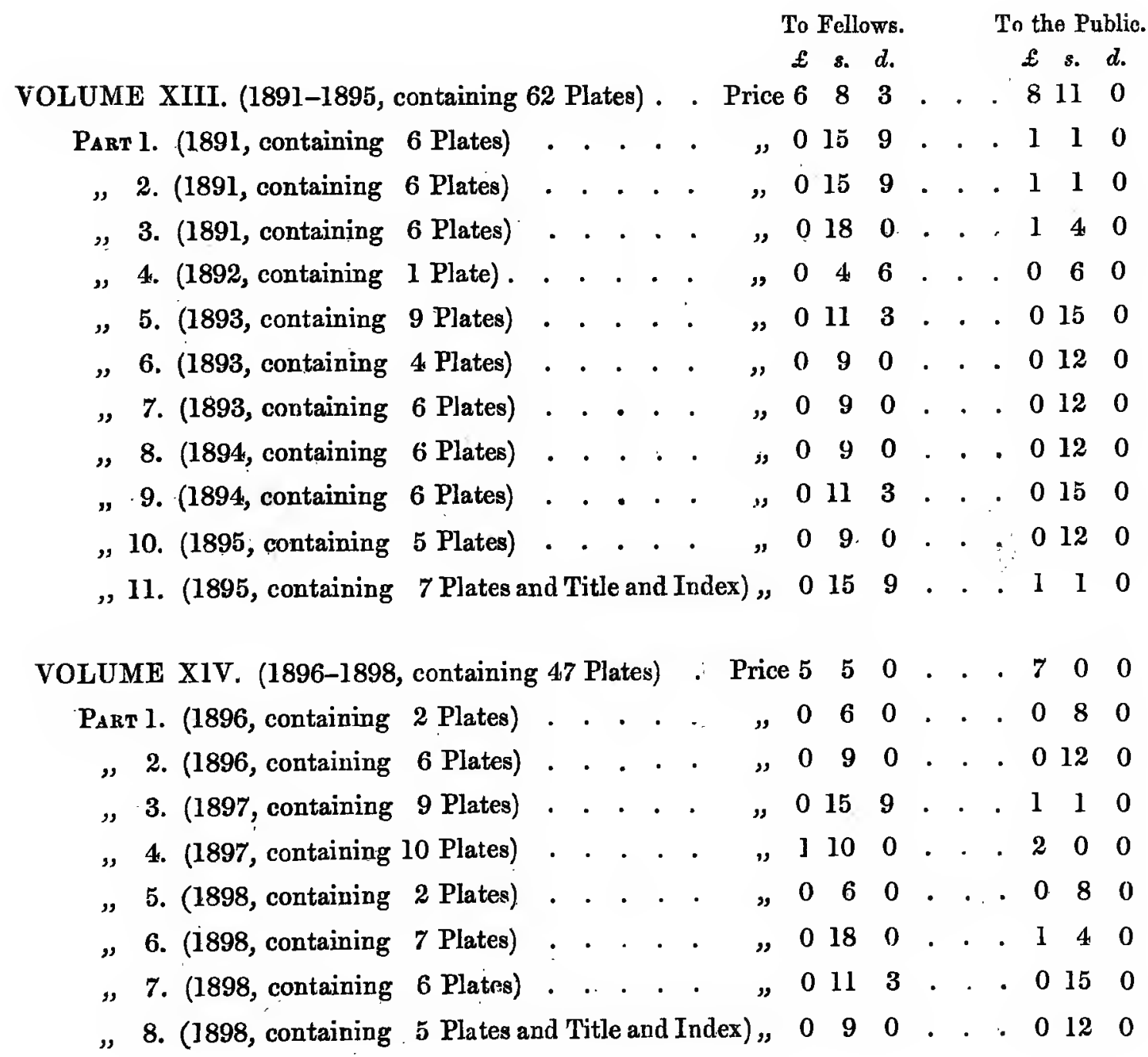

\section{VOLUME XV.}

Part 1. (1898, containing 8 Plates) . . . . . Price 0159 . 4 . . 1 . 110 


\title{
C O N T E N T S.
}

\author{
$=$ \\ I. Report on the Collection of Fishes made by Mr. J. E. S. Moore in Lake Tanganyika \\ during his Expedition, 1895-96. By. G. A. BodLenger, F.R.S., F.Z.S. With \\ an Appendix by J. E. S. Moone, A.R.C.S. (Plates I.-VIII.) · . . page 1
}

\section{THE PUBLICATIONS OF THE ZOOLOGICAL SOCIETY OF LONDON.}

The scientific publications of the Zoological Society of London are of two kinds-ce Proceeding so published in an octavo form, and "Transactions," in quarto.

According to the present arrangements, the "Proceedings" contain not only notices of all business transacted at the scientific meetings, but also all the papers read at such meetings and recommended to be published in the "Proceedings" by the Committee of Publication. A large number of coloured plates and engravings are attached to each annual volume of the "Proceedings," to illustrate the new or otherwise remarkable species of animals described in them.: Among such illustrations, figures of the new or rare species acquired in a living state for the Society's Gardens are often given.

The "Proceedings" for each year are issued in four parts, on the first of the months of June; August, October, and April, the part published in April completing the rolume for the preceding year.

The "Transactions" contain such of the more important communications made to the scientific meetings of the Society as, on account of the nature of the plates required to illustrate them, are better adapted for publication in the quarto form. They are issued at irregular intervals.

Fellows and Corresponding Members, upon payment of a Subscription of $\$ 1$ ls. before the day of the Anniversary Meeting in each year, are entitled to receive all the Society's Publications for the year. They are likewise entitled to purchase the Publications of the Society at 25 per cent. less than the price charged for them to the Public. A further reduction of 25 per cent. is made upon purchases of Publications issued prior to 1871, if they exceed the value of five pounds.

Fellows also have the privilege of subscribing to the Annual Volume of the 'Zoological Record" for a sum of $£ 1$ (which includes delivery in the United Kingdom only), but this privilege only holds good if the subscription is paid before the First of December in each year.

Such of these publications as are in stock may be obtained at the Society's Office (3 Hanover Square, W.), at Messrs. Longmans', the Society's pullishers (Paternoster Row, E.C.), or through any bookseller.

December 1898.

P. L. SCLATER, Secretary. 


\title{
TRANSACTIONS
}

\author{
OF
}

\section{THE ZOOLOGICAL SOCIETY \\ OF LONDON.}

Vol. XV.-PART 4.

\begin{abstract}
L O N D O N :
PRINTED FOR THE SOCIETY,

SOLD AT THEIR HOUSE IN HANOVER-SQUARE;

AND BY MFSSRS. LONGMANS, GREEN, AND CO., PATERNOSTER-ROW.

December 1899.
\end{abstract}

Price 12s. 


\title{
TRANSACTIONS OF THE ZOOLOGICAL SOCIETY OF LONDON.
}

\author{
To Fellows.- To the Public. \\ $£$ s. $d . \quad \&$ s. $d$. \\ VOLUME $\quad$ I. (1833-1835, containing 59 Plates). . Price 3136 . . . $4180 *$ \\ VOLUME II. (1835-1841, containing 71 Plates) . . „ , $4 \begin{array}{lllllllll} & 4 & 0 & 0 & \text {. } & 5 & 6 & 6^{*}\end{array}$ \\ VOLUME III. (1842-1849, containing 63 Plates). . „ „ $\begin{array}{cccccccccc} & 3 & 8 & 3 & . & . & 4 & 11 & 0^{*}\end{array}$

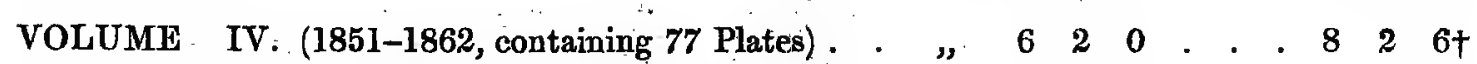

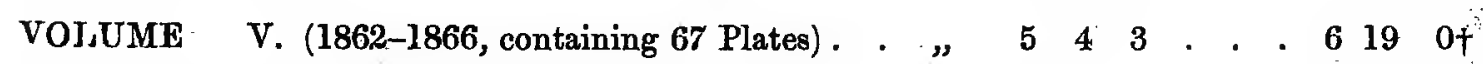

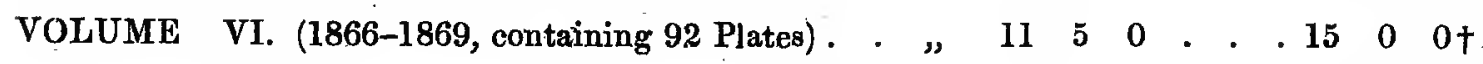 \\ VOLUME VII. (1869-1872, containing 73 Plates) . . , , $104 \cdot 0 . \quad . \quad 13120+$ \\ VOLUME VIIJ. (1872-1874, containing 82 Plates). . . $\quad, \quad \begin{array}{llllllllll} & 9 & 8 & 3 & . & . & 12 & 11 & 0\end{array}$

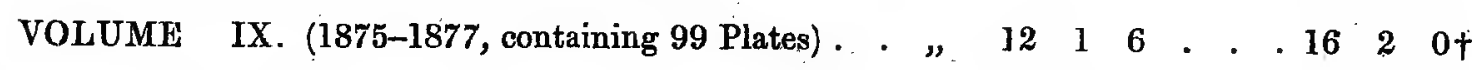

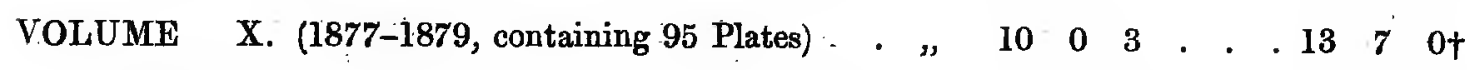

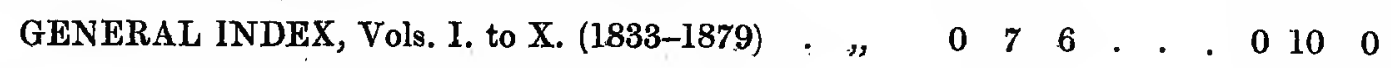

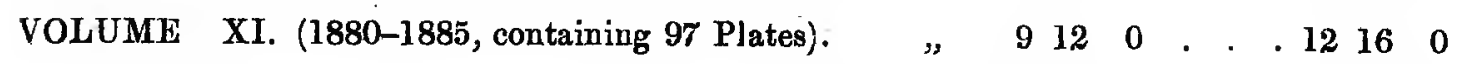 \\ VOLUME XII. (1886-1890, containing 65 Plates) . . , $\quad 5 \quad 5 \quad 8 \quad 0 \%, \quad . \quad 7 \quad 7 \quad 4 \quad 0$ \\ * No copies of these volumes remain in stock. \\ $\dagger$ Only complete copies of these volumes are left in stock.
}

Continued on page 3 of Wrapper. 
IV. Second Cortribution to the Ichthyology of Lake Tanganyika.-On the Fishes obtained by the Congo Free State Expedition under Lieut. Lemaire in 1898. By; G. A. Boulexger, F.R.S., F.Z.S.

Received May 13, read May 16, 1899.

\section{[Plates XVIII.-XX.]}

THE extraordinary richness of Lake Tanganyika in Perciform fishes of the family Cichlida, first revealed by Mr. Moore's collection, reported upon in these 'Transactions, vol. xv. 1898, pp. 1-30, pls. i.-viii., is further shown by the collection made in JulyAugust 1898 by the Lemaire Expedition at Moliro, at the southern extremity of the Lake, already explored by Mr. Moore. Although consisting of no more than 34 specimens, the collection entrusted to me for description by the Government of the Congo Free State contains the types of ten new species, three of which warrant the establishment of new genera. These new genera are of further interest in emphasizing a feature of the 'Tanganyika Cichlidec to which I have drawn special attention in my previous contribution, p. 2 , viz. the extent of the lateral lines in many of the forms discovered by Mr. Moore. The knowledge of forms with three lateral lines, a condition previously unrepresented in the Cichlida, adds force to the remarks I have made with regard to the morphological significance of the so-called "interrupted lateral line."

'The Lemaire collection is further valuable for the care with which coloured sketches of most of the fishes have been taken on the spot by M. Dardenne, the excellent artist attached to the expedition. These sketches have enabled me to represent some of the more strikingly coloured forms in chromolithography.

In addition to the definitions of the new species, I am able to draw up descriptions of the two species of Ectodus of which very incomplete definitions were given in the previous contribution, owing to the bad condition of the type-specimens. I have also added notes on the known species of which specimens are contained in the Lemaire collection, or of which coloured drawings, accompanied by an indication of the native names, have been supplied by M. Dardenne.

vol. XV.-PART Iv. No. 1.-December, 1899. 
SERRANID A.

1. Lates Microlepis Blgr.

Originally described from young specimens, 155 millim. long. The adult, measuring 800 millim. and weighing 14 lbs., has, as could be expected, very different proportions and is of a uniform dark silvery colour. The eye is contained 9 times in the length of the head, which is $\frac{1}{3}$ of the total; longest dorsal spine $\frac{1}{2}$ length of head. Caudal peduncle and caudal fin as in the young.

Native name: "Sangala,"

\section{I C H L I D}

\section{Lamprologus lemairi, sp. n. (Plate XVIII. fig. 1.)}

A few moderately large curved canine teeth in front of each jaw, followed by a narrow band of minute teeth; lateral teeth very small. Depth of body $3 \frac{1}{2}$ times in total length, length of head $2 \frac{3}{4}$. Snout slightly longer than the diameter of the eye, which is $3 \frac{1}{3}$ times in length of head and nearly double interorbital width; maxillary extending to slightly beyond vertical of anterior border of eye; cheeks and occiput naked; a few small deciduous scales on the opercles. Gill-rakers short, 9 on lower part of anterior arch. Dorsal XIX 7 ; spines equal from the fifth, which measures a little more than $\frac{1}{3}$ length of head and $\frac{3}{4}$ longest soft rays. Pectoral $\frac{3}{5}$ length of head. Ventral reaching origin of anal. Anal VIII 5 ; spines increasing in length to the last, which slightly exceeds longest dorsals. Caudal rounded. Caudal peduncle a little longer than deep. Scales $48 \frac{10-I I}{16}$; lat. 1. $\frac{30}{17}$. Pale brown, most of the scales darkedged; a blackish oblique bar from below the anterior third of the eye to the maxillary; a large blackish opercular spot; three oblique blackish bands, descending forwards, on each side of the back, extending on the base of the dorsal; dorsal and anal tipped with blackish.

'Total length 107 millim.

A single specimen.

This species takes its place in the series between $L$. moorii and L. congoensis.

3. Telmatochromis temporalis Blgr.

Native name: "Muchétila."

4. Paratilapia dewindti, sp. n. (Plate XVIII. fig. 2.)

Teeth very small, in 3 or 4 series in buth jaws, the outer scarcely larger and not tipped with brown. Jepth of body equal to length of head, nearly 3 times in total 
length. Snout with curred upper profile, shorter than the eye, the diameter of which is $2 \frac{2}{3}$ to $2 \frac{3}{4}$ in length of head and exceeds interorbital width; maxillary extending to below anterior fourth of eye; 2 or 3 series of scales on the cheek; large scales on the opercle. Gill-rakers rather long, lanceolate, 17 or 18 on lower part of anterior arch. Dorsal XII-XIII 12-13; spines increasing in length to the eighth or ninth, which measures $\frac{2}{5}$ or $\frac{1}{2}$ length of head and $\frac{3}{4}$ longest soft rays. Pectoral a little shorter than bead, extending as far as origin of anal. Ventral produced into a long filament, extending beyond origin of anal. Anal III 9 ; third spine longest, $\frac{2}{5}$ length of head; middle soft rays produced, as long as or a little shorter than head. Caudal deeply emarginate, crescentic. Caudal peduncle $1 \frac{1}{3}$ as long as deep. Scales finely denticulate on the edge, $37-38_{13}^{4}$; lat. $1 . \frac{29-30}{14-15}$; upper lateral line not reaching base of caudal. Grey above, white beneath; four yellowish stripes along each side; pectorals yellowish; other fins lark grey or blackish.

Total length 100 millim.

Three specimens.-Native name: "Likuko."

This species is named in memory of the distinguished young geologist, Dr. De Windt, attached to Lieut. Lemaire's expedition, who was accidentally drowned in Lake Tanganyika. It is very closely allied to $P$. ventralis Blgr., from which it differs in the dentition and in the shorter pectoral fin.

5. Bathybates Ferox Blgr.

Native name: "Musupa."

\section{'Trimatocara, g. n.}

Closely allied to Paratilapia, but with the teeth very minute, in a narrow band in both jaws, the maxillary entirely concealed under the præorbital when the mouth is closed, the muciferous cavities of the top and sides of the skull and of the mandible extremely large, as in Acerina, and with a single, incomplete, lateral line.

\section{Trematocara marginatum, sp. n. (Plate XIX. fig. 1.)}

Depth of body $3 \frac{1}{2}$ times in total length, length of head $2 \frac{2}{3}$ to 3 . Snout with curved upper profile, shorter than the eye, which is $2 \frac{1}{2}$ in length of head and exceeds interocular width; mouth extending to below anterior border of eye; cheek naked; a few deciduous scales on the opercle; nasal, frontal, præ- and suborbital, præopercular, and mandibular bones with very large and deep cavities separated by narrow septa and 
covered with a thin skin. Gill-rakers short, 10 on lower part of anterior arch. Dorsal $\mathrm{X} 11$; spines $\frac{2}{5}$ length of head, a little shorter than longest soft rays. Pectoral acutely pointed, as long as head. Ventral reaching origin of anal. Anal III 10 ; third spine nearly as long as dorsals. Caudal with deep crescentic notch. Caudal peduncle $1 \frac{1}{2}$ as long as deep. Scales cycloid, $30 \frac{3}{8}$; lateral line reduced to a few (6 or 7 ) short tubes in the upper series. Pale brownish above, white beneath; a bluish lateral stripe; fins yellowish, dorsal and anal edged with blackish.

Total length 63 millim.

Two specimens.-Native name : "Lilowé."

\section{Grammatotria, g. n.}

Body elongate; scales ctenoid; three incomplete lateral lines. Jaws narrow, with a band of minute conical teeth and an outer series of rather longer ones; maxillary concealed under the præorbital when the mouth is closed. A large papillose pad on each side of the pharynx, between the gills. Dorsal with 15 spines, anal with 3 .

7. Grammatotrin Lemairil, sp. n. (Plate XVIII. fig. 3.)

Depth of body 4 times in total length, length of head 3. Snout with slightly convex upper profile, $1 \frac{1}{2}$ diameter of eye, which is $3 \frac{2}{3}$ in length of head and equals interocular width; maxillary extending to between nostril and eye; 3 series of scales on the cheek; opercle covered with scales. Gill-rakers short, 12 on lower part of anterior arch. Dorsal XV 14; spines slender, equal from the fifth, which measures nearly $\frac{1}{3}$ length of head; soft rays not longer than the spines. Pectoral acutely pointed, nearly as long as head, extending as far as origin of anal. Ventral reaching vent. Anal III 10 ; third spine a little stronger and shorter than longest dorsals. Caudal with deep crescentic notch. Caudal peduncle $2 \frac{1}{3}$ as long as deep. Scales $55 \frac{6-7}{13}$; lat. 1. $\frac{\frac{48-52}{26}}{13-15}$. Pale brown above, yellowish beneath; a small dark brown opercular spot; a round brown spot on caudal peduncle at root of caudal fin; dorsal fin greyish, the soft portion with round white spots; other fins yellowish.

Total length 175 millim.

A single specimen.-Native name: "Murungi."

8. Ectodus ${ }^{1}$ Descumpsi Blgr. (Plate XIX. fig. 2.)

Depth of body $3 \frac{1}{2}$ times in total length, length of head 3. Snout short, with curved

1 To the generic characters as given in the original description must be added the presence of a large dermal pad in frout of the upper part of the gill-arches, same as in Pelmatochromis and Chromidotilapia. 
upper profile, slightly shorter than the eye, the diameter of which is $2 \frac{4}{5}$ in length of head and equals $1 \frac{1}{2}$ interorbital wiclth; maxillary extending to between nostril and eye; two series of scales on the cheek; opercle naked. Gill-rakers short, 11 on lower part of anterior arch. Dorsal XIII 13 ; spines slender, increasing in length to the last, which is about $\frac{2}{5}$ length of head and little shorter than the soft rays. Anal III 8 ; third spine slightly shorter than longest dorsals. Pectoral obtusely pointed, $\frac{2}{3}$ length of head. Ventral reaching vent. Caudal emarginate. Caudal peduncle $1 \frac{1}{2}$ a slong as deep. Scales $35 \frac{3}{11}$; at 1. $\frac{27}{14}$. Pale brown above, yellowish beneath; fins yellow; a round blackish spot on the hinder part of the spinous dorsal.

Total length 60 millim.

A single specimen.

9. Ectodus Melanogenys Blgr. (Plate XIX. fig. 3.)

Depth of body 5 to $5 \frac{1}{4}$ times in total length, length of head $3 \frac{1}{2}$. Snout long, with nearly straight upper profile, $1 \frac{2}{3}$ diameter of eye, which is 4 times in length of head and equals or slightly exceeds interorbital width; maxillary extending to between nostril and eye; 3 series of scales on the cheek; deciduous scales on the opercle. Gill-rakers short, 12-13 on lower part of anterior arch. Dorsal XIII-XIV 17 ; spines slender, increasing in length to the last, which is about $\frac{2}{5}$ length of head; last soft rays produced, at least half length of head. Anal III 13; third spine $\frac{1}{3}$ length of head. Pectoral pointed, a little shorter than head. Ventral reaching origin of anal. Caudal deeply emarginate. Caudal peduncle twice as long as deep. Scales 43-44 $\frac{3-4}{10}$; lat. 1. $\frac{30-31}{14-16^{\circ}}$ Grey above, white below; dorsal scales with a pale blue central spot; a blackish opercular spot; chin and branchiostegal membrane blackish ; dorsal grey, with whitish streaks and spots, and a large oval blackish spot in the middle of the spinous portion; anal grey, streaked with whitish; pectoral and caudal yellowish, the latter with crescentic dark bands; ventral blackish at the end.

Total length 110 millim.

Two specimens.-Native name: "Losorella."

10. Ectodus longianalis, sp. n. (Plate XIX. fig. 4.)

Depth of body 5 times in total length, length of head 3. Snout long, with slightly convex upper profile, $1 \frac{1}{2}$ diameter of eye, which is $3 \frac{1}{2}$ times in length of head and nearly $1 \frac{1}{2}$ interorbital width ; maxillary extending to between nostril and eye; 3 series of scales on the cheek; deciduous scales on the opercle. Gill-rakers short, 12 on lower part of anterior arch. Dorsal XV 15; spines slender, increasing in length to the 
last, which is $\frac{1}{3}$ length of head; soft rays slightly longer, the last not produced, Anal III 17 ; third spine $\frac{1}{4}$ length of head. Pectoral pointed, $\frac{4}{5}$ length of head. Ventral nearly reaching origin of anal. Caudal deeply emarginate. Caudal peduncle twice as long as deep. Scales $44 \frac{3}{9}$; lat. 1. $\frac{31}{17-18}$. Brownish above, whitish beneath; a blackish opercular spot; a lateral series of rather indistinct dark spots; dorsal greyish; other fins yellow.

Total length 97 millim.

A single specimen, with the mouth and pharynx full of advanced embryos.

The characters of the 3 species of Ectodus may be contrasted as follows :-

E. descampsi. D. XIII-XIV $13-14$. A. III 8. Sq. $34-35 \frac{3}{10-11}$; lat. 1. $\frac{27-28}{14-15}$. Depth of body $3 \frac{1}{2}-3 \frac{4}{5}$ in total length. Snout slightly shorter than eye.

E. melanogenys. D. XIII-XIV 16-17. A. III 13. Sq. $43-44 \frac{3-4}{10}$; lat. I. $\frac{30-31}{14-16}$. Depth of body $5-5 \frac{1}{4}$ in total length. Snout much longer than eye.

E. longianalis. D. XV 15. A. III 17. Sq. $44 \frac{3}{9}$; lat. 1. $\frac{31}{17-18}$. Depth of body 5 in total length. Snout much longer than eye.

\section{Xenotillapia, g. n.}

Body moderately elongate; scales ctenoid; three lateral lines. Mouth small, very protractile; upper jaw with series of minute conical teeth; two mandibular teeth turned outwards, in a single series; maxillary concealed under the præorbital when the mouth is closed. A large papillose pad on each side of the pharynx, between the gills. Dorsal with 14 or 15 spines, anal with 3 .

\section{Xenotilapia sima, sp. n. (Plate XIX. fig. 5.)}

Depth of body 4 times in total length, length of head $3 \frac{1}{4}$. Snout very short and deep, with very steep convex upper profile; eye very large, oval, its diameter $\frac{2}{5}$ length of head and much greater than interorbital width; mouth nearly straight, horizontal, extending to below anterior border of eye; 3 or 4 series of scales on the cheek; deciduous scales on the opercle. Gill-rakers very short, broad, truncate, 9 on lower part of anterior arch. Dorsal XIV-XV 12 ; spines subequal from the fifth, $\frac{1}{3}$ length of head; longest soft rays $\frac{2}{5}$ length of head. Pectoral acutely pointed, as long as head. Ventral with the inner ray produced and reaching a little beyond origin of anal. Anal III 1I; third spine $\frac{1}{3}$ length of head. Caudal with deep crescentic notch. Candal peduncle twice as long as deep. Scales strongly ciliated, $40-41 \frac{3-4}{10-11}$; lat. $1 . \frac{32-36}{21-22}$. 
Pale brownish, with a few round darker spots; a blackish opercular spot; a shining golden spot on the subopercle; dorsal greyish, other fins yellowish.

Total length 105 millim.

Two specimens.-Native name: "Lufuina."

\section{Tilapia labiata Blgr.}

Native name: "Kobo."

13. Tilapia dardennil, sp. n. (Plate XX. fig. 1.)

Teeth very small, in 4 or 5 series in both jaws, outer bicuspid, separated from the series of smaller tricuspid teeth by a rather wicle interspace. Depth of body 3 to $3 \frac{1}{3}$ times in total length, length of head $3 \frac{1}{3}$ to $3 \frac{1}{2}$. Snout with strongly curved upper profile, little longer than the diameter of the eye, which is $3 \frac{1}{2}$ times in length of head and equal to or a little less than interorbital width; mouth small, $\frac{3}{5}$ width of head, extending to between nostril and eye; 5 or 6 series of scales on the cheek; large scales on the opercle. Gill-rakers short and thick, 13 on lower part of anterior arch. Dorsal XIX 10 ; sixth to ninth spines longest, not quite half length of head, a little shorter than longest soft rays. Pectoral acutely pointed, as long as or slightly shorter than the head, not extending to origin of anal. Ventral reaching vent or not quite so far. Anal III 8; third spine as long as and much stronger than longest dorsals. Caudal feebly emarginate. Caudal peduncle $1 \frac{2}{3}$ or $1 \frac{3}{4}$ as long as deep. Scales mostly ctenoid, $37 \frac{5}{11}$; lat. 1. $\frac{24-25}{17-19}$. Yellowish olive above, silvery beneath, with 10 or 11 dark dorsal cross-bars, the first between the eyes; yellowish streaks along the series of scales; fins yellowish, dorsal with some olive marblings, pectoral and anal red at the base.

Total length 155 millim.

'Two specimens.-Native name: "Sangani."

\section{Tilapia rubropunctata, sp. n. (Plate XX. fig. 2.)}

Teeth very small, in 4 or 5 series in both jaws, outer bicuspid, separated from the series of smaller tricuspid teeth by a rather wide interspace. Depth of body 3 times in total length, length of head $2 \frac{2}{3}$. Snout with straight upper profile, twice as long as diameter of eye, which is $4 \frac{1}{2}$ times in length of head and equals interorbital width; mouth large, $\frac{3}{4}$ width of head, extending to between nostril and eye; a few deciduous scales on the cheek; large scales on the opercle. Gill-rakers short, rather slender, 12 or 13 on lower part of anterior arch. Dorsal XVI 9 ; spines equal in length from the 
sixth or seventh, measuring $\frac{1}{3}$ length of head and $\frac{2}{3}$ longest soft rays. Pectoral obtusely pointed, $\frac{2}{3}$ length of head, not extending to origin of anal. Ventral reaching vent. Anal III 7 ; third spine a little shorter than longest dorsals. Caudal truncate. Caudal peduncle as long as deep. Scales mostly cycloid, a few on the sides of the body below the lateral line finely denticulate, $32-33 \frac{4-5}{\overline{1} 1-12}$; lat. $1 . \frac{22}{12-13}$. Olive-brown above, pale yellow beneath ; dark cross-bars on the back; each scale of the back and sides with a central vermilion spot; head spotted and marbled with dark purplish brown; lower jaw and lower part of opercular region bright yellow; dorsal and caudal fins bright yellow, spotted with dark brown; pectoral yellow; branchiostegal membrane, pectoral region, outer edge of ventrals, and anal vermilion-red.

Total length 120 millim.

Two specimens of this handsomely-coloured fish, which bears the native name “Kasanga Malengi" on M. Dardenne's coloured sketch.

15. Tilapia microlepis, sp. n. (Plate XX. fig. 3.)

Teeth very small, in 4 series close together in both jaws, outer larger, bicuspid, with a principal and a small lateral cusp. Depth of body $3 \frac{2}{3}$ to 4 times in total length, length of head 3. Snout with straight or slightly convex upper profile, once and a half the diameter of the eye, which is nearly 4 times in length of head and equals interorbital width; mouth moderate, its width $\frac{3}{5}$ that of the head, extending to between nostril and eye; 7 or 8 rows of scales on the cheek; larger scales on the opercle. Gill-rakers short, rather thick, 13 or 14 on lower part of anterior arch. Dorsal XVIXVII 14-15; spines subequal in length from the fifth or sixth, measuring $\frac{1}{3}$ length of head and a little shorter than longest soft rays. Pectoral acutely pointed, 童 length of head, not extending to origin of anal. Ventral widely separated from vent. Anal III 9 ; third spine as long as and a little stronger than longest dorsals. Caudal with deep crescentic notch. Caudal peduncle twice as long as deep. Scales cycloid, 80-90 $\frac{10}{2 y-30}$; lat. 1. $\frac{46-49}{38-44^{\circ}}$ Pale olive-brown above, white below; faint dark bars across the back and four round dark spots on each side, the last at the root of the caudal; fins yellowish.

Total length 115 millim.

Two specimens.-Native name: "Mocupi."

As in Tilapia desfontainesi, the dentition of this species may be regarded as connecting Tilapia with Paratilapia

16. Tilapia grandoculis, sp. n, (Plate XIX. fig. 6.)

Teeth very small, in 4 or 5 series in both jaws, of outer series larger, bi- or tricuspid, 
and very obtuse. Depth of body $3 \frac{3}{4}$ times in total length, length of head 3 . Snout short, with rounded upper profile; eye very large, a little longer than the snout, its diameter $2 \frac{1}{2}$ in length of head, and slightly greater than the interorbital width; mouth small, $\frac{1}{2}$ width of head, extending to between nostril and eye; a few deciduous scales on the cheek; larger scales on the opercle. Gill-rakers very short, rather thick, 17 on lower part of anterior arch. Dorsal XIII 14; spines slender, equal in length from the seventh, measuring $\frac{2}{5}$ length of head, and a little shorter than longest soft rays. Pectoral falciform, slightly longer than the head, extending as far as origin of anal. Ventral prolonged in a long filament, extending beyond origin of anal. Anal III 10; third spine shorter but stronger than longest dorsals. Caudal with deep crescentic notch. Caudal peduncle a little longer than deep. Scales mostly ctenoid, $63 \frac{7}{25}$; lat. 1. $\frac{58-60}{32-36^{\circ}}$. Brown above, with ill-defined darker spots, whitish beneath; pectorals yellowish; other fins blackish towards the edge.

Total length 115 millim.

A single specimen.

\section{S I L U R I D \&.}

17. Auchenaspis biscutata Geoffr.

Native name: "Porocco."

18. ChrYsicht'HYS CRANCHII Leach.

Two young specimens are in the collection. A larger specimen is represented in the series of drawings made by Mr. Moore.

19. Synodontis Multipunctatus Blgr.

The young (150 millim.) have the spots on the head and body larger and fewer. Native name: "Katétia."

\section{H A R A C I N I D \&.}

20. Alestes macrolepidotus C. \& V.

Native name : "Ilala."

21. Alestes macrophthalmus Gthr.

Native name: "Laala."

vol. XV.-PART IV. No. 2.-December, 1899. 


\section{CYPRINODONTID}

22. Haplochilus tanganicanus Blgr.

Native name: "Mohanga."

\section{EXPLANATION OF THE PLATES.}

\section{PLATE XVIII.}

Fig. 1. Lamprologus lemairii, p. 88.

Fig. 2. Paratilapia dewindti, p. 88.

Fig. 3. Grammatotria lemairii, p. 90.

\section{PLATE XIX.}

Fig. 1. Trematocara marginatum, p. 89. 1 a. Side view of head;

$1 \mathrm{~b}$. Lower view of head, enlarged.

Fig. 2. Ectodus descampsi, p. 90.

Fig. 3. " melanogenys, p. 91.

Fig. 4. " longianalis, p. 91 .

Fig. 5. Xenotilapia sima, p. 92.

Fig. 6. Tilapia grandoculis, p. 94 .

\section{PLATE XX.}

Fig. 1. Tilapia dardennii, p. 93.

Fig. 2. " rubropunctata, p. 93.

Fig. 3. , microlepis, p. 94. 


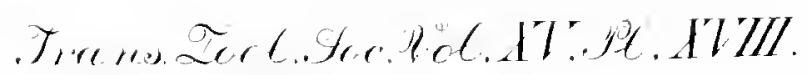

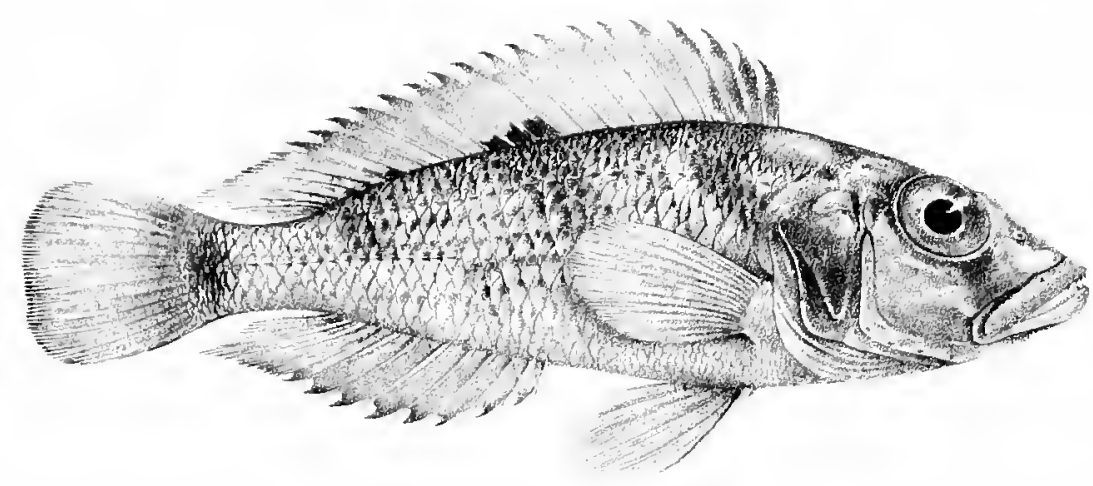

1
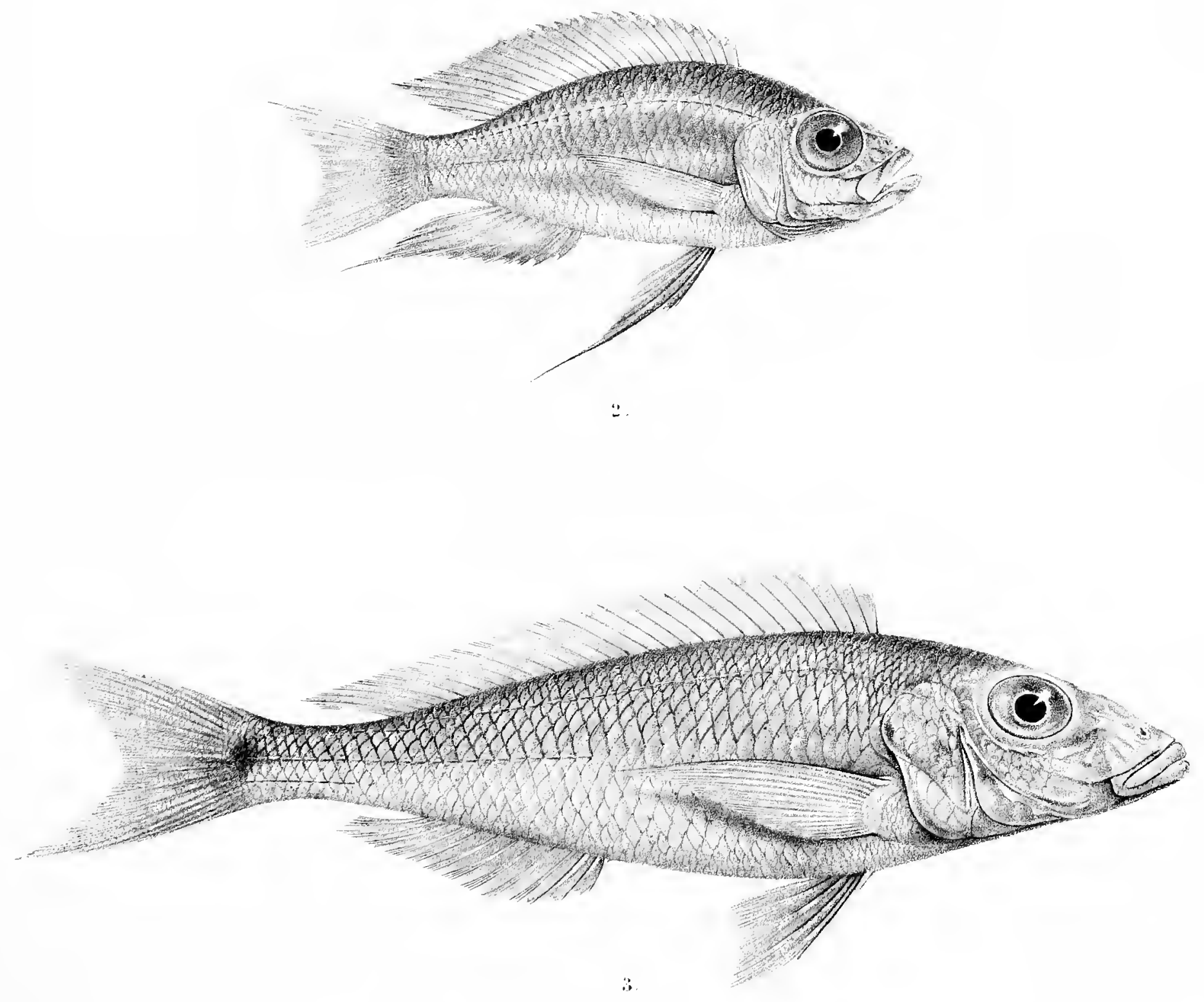

WhateTn Eros ish 



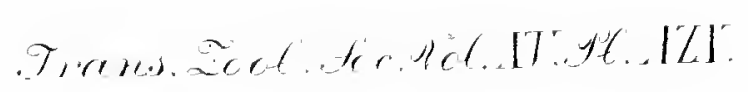

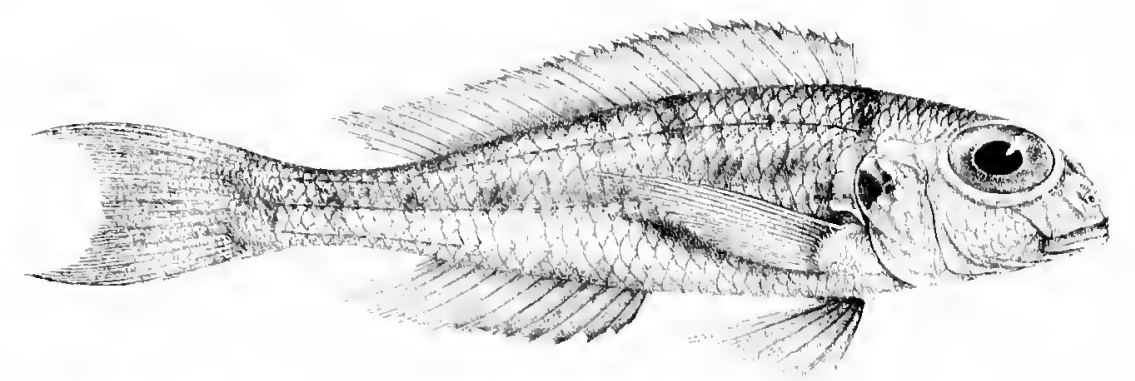

5.

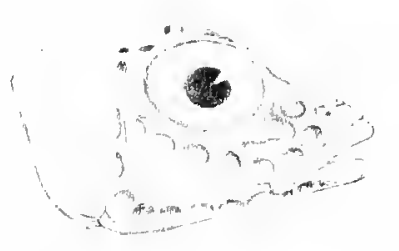

Lis

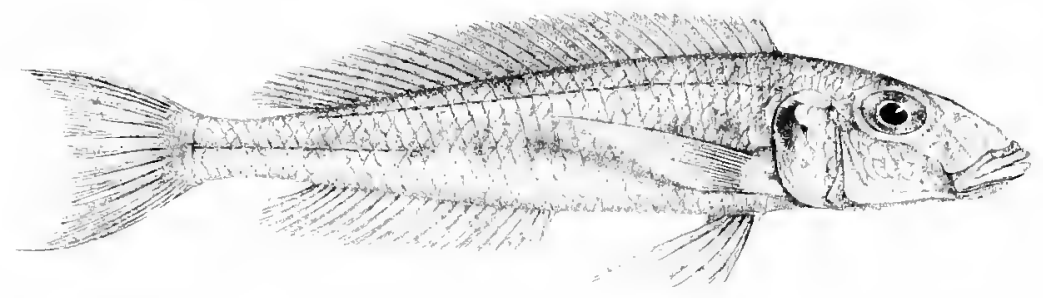

4
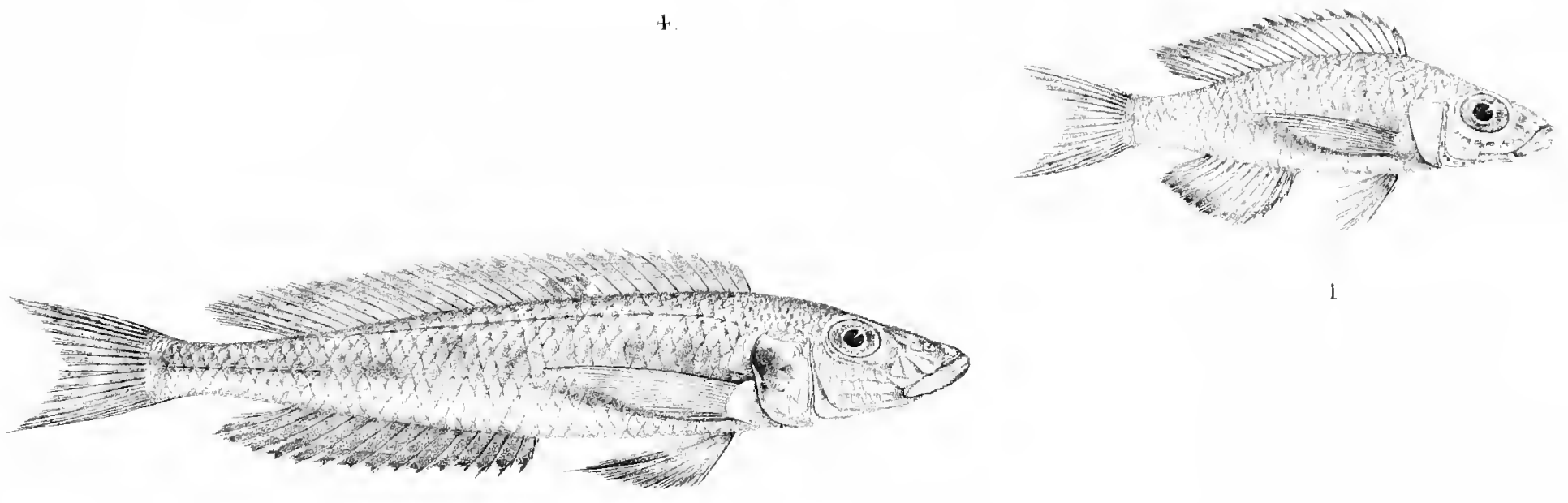

:
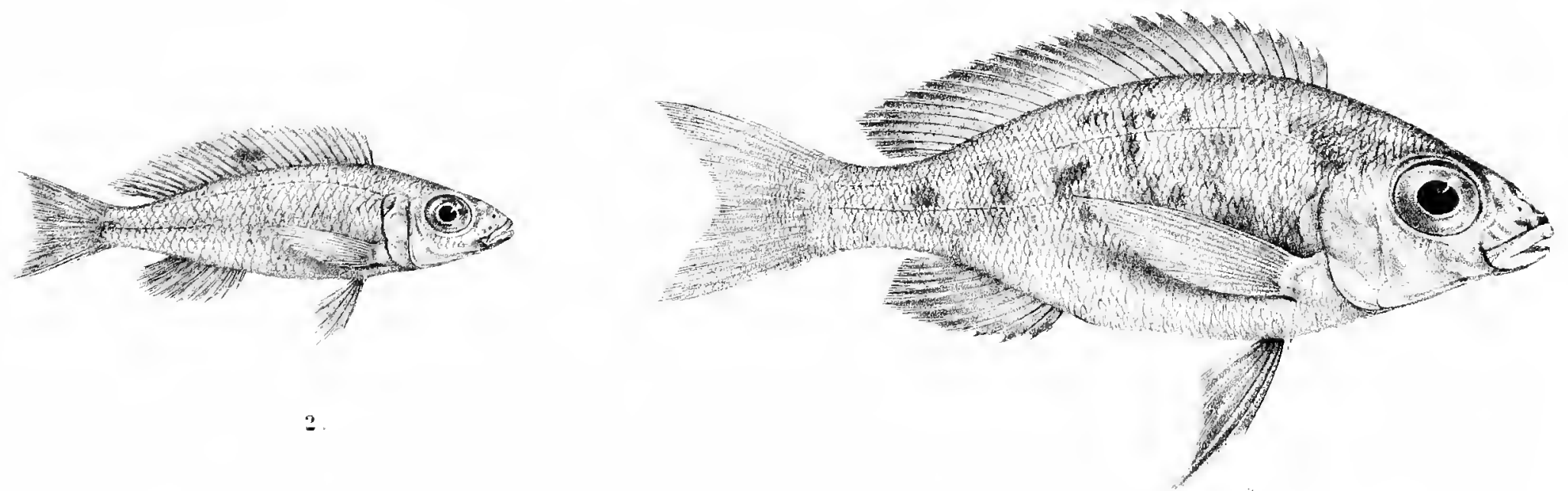

b 


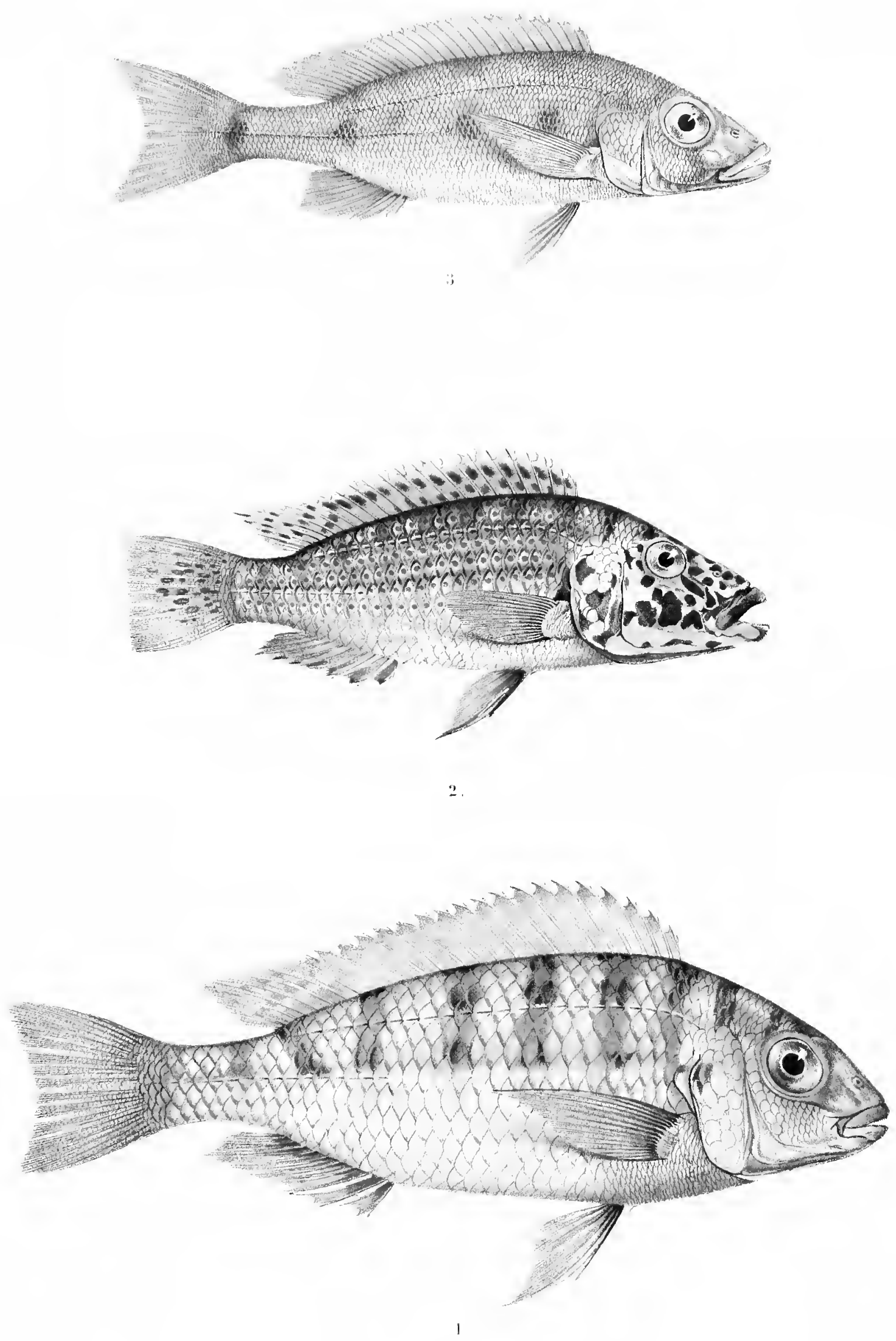

V. On a Specimen of Cervus belgrandi Lart. (C. verticornis Dawk.) from the ForestBed of East Anglia. By Sidney F. Harmer, Sc.D., F.R.S., Superintendent of the University Museum of Zoology, Cambridge. ${ }^{1}$

Received April 24, read June 6, 1899.

\section{[Plate XXI.]}

THE specimen which forms the subject of the present paper is from the Forest-Bed series of Pakefield, near Lowestoft, where it was found as a result of the great destruction of the cliff due to the high tides of November 1897. The pieces were obtained from the men who had dug it out by my assistant, Ernest Lane, to whom is due the credit of recognizing the importance of the specimen, which is now in the University Museum of Zoology at Cambridge.

I have been unable to find a record of any specimen belonging to this species which will compare with the present one in completeness. The posterior part of the skull, including the whole of the brain-case, is in excellent condition. The anterior parts, from the orbital region, are wanting. The left antler is nearly complete, and the parís which are missing are to some extent represented in the right antler, a large part of which is also present. The atlas and axis were found associated with the skull.

The specimen throws considerable light on the real characters of the antlers of the form usually known as Cervus verticornis; and in particular it demonstrates the incorrectness of the diagnosis which is usually given of this species. C. verticornis was originally described by Professor W. Boyd Dawkins ${ }^{2}$, and a fuller account of it was given by the same author in a later publication ${ }^{3}$. The species is commonly represented by basal parts of the antlers only, in collections from the Forest-Bed, and is readily recognized by its massive cylindrical beam, with the brow-tine (usually situated about 2 inches above the burr) curving forwards and downwards. The restorations given by Boyd Dawkins indicate an antler which slightly widens out immediately above the back-tine, and ends in a short bifurcated tip, which was not, however, really represented in any of the specimens. Professor Dawkins's opinion, stated in his fuller account, that he cannot recognize any affinity between the antlers of $C$. verticornis and those of the

1 The abstract of this paper which appears on pp. 715, 716 of the 'Proceedings' for 1899 was published without giving me an opportunity of correcting the proof. The locality of the fossil and my conclusion with regard to the nomenclature are incorrectly statod in it.-S. F. H., Nov. 13, 1899.

2 "On the Cervidæ of the Forest-Bed of Norfolk and Suffolk," Quart. J. Geol. Soc. xxriii. (1872), p. 406.

3 “ British Pleistocene Mammalia.--VI. British Pleistocene Cervidæ," Palæontographical Society, 1887. 
Irish Deer (C. giganteus) was no doubt the result of this inadequate restoration, which is also responsible for such statements as those of Flower and Lydekker ${ }^{1}$ that the antlers are very short and thick, or of Lydekker ${ }^{2}$ that their palmation is generally slight.

The Pakefield specimen shows, on the contrary, that $C$. verticornis belongs to a type comparable with the Irish Deer not only in its size but in the amount of the palmation of the antlers, though differing from it in the absence of prominent snags springing from the palmated extremity. It fully bears out the conclusion stated by Lydekker ${ }^{3}$ that this form indicates the ancestral stock of $C$. giganteus.

The specimen measures 6 feet in a straight line between the extreme points of the antlers, but this measurement hardly gives a correct idea of its real size. The crown of the right antler rises nearly vertically, while that of the left antler is much more horizontally expanded, besides being more perfect. The distance of the distal extremity of the left antler from the middle line of the skull is thus no less than 4 feet 5 inches. If both antlers had been equally well preserved and if the direction of the right antler had been as horizontal as that of the left antler, the total span, in a straight line, would have been 7 feet 3 inches. The more complete left antler is no less than 52.6 inches, measured along the curve ; its pedicle is 2.9 inches in diameter (dorso-ventral) and the burr is $3 \cdot 6$ inches. The brow-tine $(b)$ is 2 inches above the burr and is perfectly typical, springing from the back of the beam in such a way that its posterior surface is level with the posterior surface of the beam. The anterior surface of its base is hollowed out, and beneath it there is a slight tubercle corresponding with the accessory tines or with the "offers" described by Boyd Dawkins ${ }^{4}$ in the same position. This is hardly indicated in the right antler. The beam is nearly cylindrical and is strongly furrowed by grooves for blood-vessels, which run in a longitudinal direction without showing any tendency to become spiral. Two inches above the brow-tine, the beam measures 2.6 inches in greatest diameter, its anterior part soon afterwards becoming flattened in a dorso-ventral direction to form the second tine (c), which is only represented by its base, the proximal edge of which is about 7 inches from the distal edge of the base of the brow-tine. Beyond the second tine, the beam nearly regains its cylindrical shape, although having a low ridge on its anterior aspect. It has hitherto been nearly straight, though slightly concave below and pointing somewhat backwards; but beyond the second tine it curves rapidly upwards, expanding and becoming flattened. At the origin of the back-tine $(d)$ it is convex on its under surface and slightly concave above. The back-tine is fairly long (6 inches, though incomplete at its tip) and is directed backwards and inwards; the distance of the proximal part of its base from

\footnotetext{
1 "Introduction to the Study of Mammals," 1891, p. 323.

2 "The Deer of all Lands," 1898, p. 140.

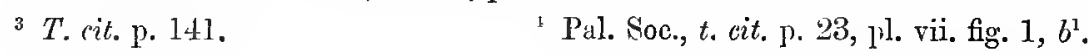


a point on the beam opposite the distal end of the base of the second tine is about 7 inches; and from the posterior edge of the burr, in a straight line, about 19 inches.

Opposite the back-tine, the beam is $2 \cdot 1$ inches in greatest dorso-ventral diameter ; and it is still 1.9 inches thick, becoming flat above, but remaining convex below, at a point 9 inches above the middle of the base of the tine. The front edge of the antler is wanting from a point 6.5 inches above the tine $c$, and for 11 inches from its lower end the fractured edge varies from $1 \cdot 4$ to $1 \cdot 7$ inches in thickness. Posteriorly the edge has been getting thinner from the back-tine, about 10 inches above which it expands into a large palmated crown, the plane of which is different from that of the part which precedes it. The beam, from the second tine to the base of the palmation, was extended upwards in a plane about $45^{\circ}$ from the median vertical plane, its edge being seen in a view of the skull from the front. The posterior edge of the crown is, on the contrary, rotated outwards and downwards, so that much of its lower surface becomes visible from in front. The posterior edge of the base of the crown is very concave, and passes obliquely upwards and backwards, the palmation extending further backwards than the end of the back-tine. The crown is quite complete except in front, and is everywhere thin, scarcely exceeding an inch in thickness in any part; its distal border is gently scalloped, about 7 points or rounded lobes being distinguishable, none of them being more than mere denticulations. The thinness of the palmated crown at its anterodistal extremity indicates that no other tines were present in this region. The part between the main palmation and the back-tine is, however, thick ( $1 \cdot 7$ inches) on its fractured anterior border; and another anterior tine may have been present in this region, or the beam may have terminated in a distinct point, as in the Belzig specimen (see woodcut, p. 104), mentioned below, or as in C. dama. From a comparison with the latter, I do not, however, think it likely that an anterior tine was present.

The right antler agrees closely with the left, except that the region above the second tine turns dorsally much more sharply than that of the other side. It is indeed almost at right angles to the beam, whereas that of the left side forms a much more open curve with the beam. The first and second tines agree almost exactly in position with those of the left side, but the second tine is much better represented, measuring $7 \cdot 5$ inches in length and being practically complete. At its base it is flattened and is a good deal broader than thick (breadth 2.8 inches, thickness 1.5 inches). The back-tine is lost. The anterior edge of the antler is complete for about 13.5 inches (measured round the curve) above the base of the second tine, and the antler is prolonged for another 10 inches above the point where the anterior edge ceases to be complete. Its thinness makes it practically certain that no other tine could have existed.

The part of the skull which is preserved measures 9 inches in greatest length, and extends as far forwards as the posterior portion of the orbit. The occipital region and the base of the skull are in good condition. The interval between the 
pedicles is wide ( 3 inches) and the pedicles are much more horizontally placed than in $C$. dama, to which the species appears to be related; they pass with an even curve into the top of the frontal, whereas in another specimen of $C$. belgrandi in the Cambridge collection they make a distinct angle with the frontal and are somewhat more vertical. The pedicles are nearly cylindrical above, but have a sharp ridge descending from their outer borders to the posterior margin of the orbit; their bases are deeply hollowed out behind, as in other species of Cervus. Below the pedicles, the skull has a median ridge, with a marked depression on either side of it, thus differing from a part of a skull described by Boyd Dawkins' ${ }^{1}$. The posterior part of the parietals (apparently just in front of the suture with the occipital) has a round foramen nearly in the middle line, and a smaller one slightly to the left side of it and rather further forwards (the other side being here injured). I have found a similar vacuity in the roof of the skull in another Forest-Bed specimen which I refer to C. savini Dawk. The transverse occipital crest is strongly marked, in correlation with the great size of the antlers, and the occipital surface is nearly vertical. Ventrally there is a very deep emargination between the condyles. There was apparently a large supra-orbital foramen, but the skull is deficient in this region.

The specimens of the Irish Deer (C. giganteus) in the Cambridge collection differ from the above in having much shorter and less marked pedicles, in the comparatively slight median ridge on the frontals and their more depressed character in this region, and in the smaller size of the supra-orbital foramen. The vertex of the skull, between the two pedicles, is less raised in $C$. belgrandi, the roof of the skull of which is practically flat from the front of the occipital crest to a point between the two pedicles. In the Irish Deer, on the contrary, the skull between the pedicles is much higher than the most prominent part of the occipital crest, from which it is separated by a distinct concavity. A striking difference, which appears to me of some importance, is that whereas in $C$. giganteus the vascular grooves on the beam of the antlers have a markedly spiral course, those of $C$. belgrand $i$ run quite straight up the beams. The race of C. giganteus found in the Barrington River-gravel agrees with the Irish Deer in this respect.

The occurrence of the atlas and axis vertebræ associated with the skull is of special interest. Their size is not far short of that of the corresponding vertebræ in an articulated specimen of the Irish Deer in the Woodwardian Museum at Cambridge, the spread of whose antlers is 8 feet 4 inches. This is brought out in the tables of measurements which follow. I have noted the following differences between the two forms, although some of them may be no more than individual peculiarities.

In the ATLAS:-The neural arch is flatter above in $C$. giganteus, while it rises externally more abruptly on the dorsal surface in $C$. belgrandi. The tip of the

${ }^{1}$ Pal. Soc., t. cit. p. 28. 
rudimentary neural spine is at the middle of the upper surface in the former, and in front of the middle in the latter. The dorsal nerve-foramina of $C$. giganteus are constricted into a figure-of- 8 shape (and completely divided by a bridge in a specimen from the Barrington gravel in the Woodwardian collection), while they are long slits in $C$. belgrandi. The neural arch of $C$. belgrandi has a wider sinus behind on its dorsal side; its anterior dorsal emargination is more square-cut: the ventral depression behind the nerve-foramen is much deeper; the hypapophysis is most prominent behind, with a median ridge passing towards the anterior end of the vertebra (that of the Woodwardian specimen of $C$. giganteus having no ridge). In some of these latter points the Barrington specimen holds an intermediate position between the two others.

In the AxIs :-The dorsal edge of the neural spine is thinner in C. belgrandi; the transverse processes, which are incomplete, were probably less projecting; the posterior zygapophyses are narrower ( 1.05 inches, as compared with $1.5-1.8$ inches) and more raised; there is a distinct emargination between the posterior zygapophysis and the neural spine; and the ventral median ridge is distinctly higher and bounded by deeper grooves at its sides than in $C$. giganteus.

In the tables which follow, the measurements have been taken in such a way as to permit of easy comparison with those given by Boyd Dawkins ${ }^{1}$, Belgrand ${ }^{2}$, and others.

I. SKULL.

\begin{tabular}{|c|c|c|}
\hline & inches. & millim. \\
\hline Greatest length of the part of the skull preserved $\ldots \ldots \ldots \ldots \ldots \ldots$. & $9 \cdot 0$ & 228 \\
\hline 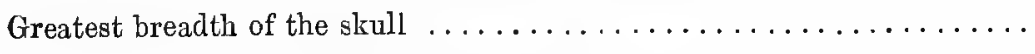 & $8 \cdot 1$ & 206 \\
\hline Occipital crest to fronto-parietal suture $\ldots \ldots \ldots \ldots \ldots \ldots \ldots \ldots$ & $4 \cdot 1$ & 104 \\
\hline$, \quad, \quad$ pedicle (shortest distance) $\ldots \ldots \ldots \ldots \ldots \ldots \ldots$ & $3 \cdot 0$ & 76 \\
\hline Interval between pedicles $\ldots \ldots \ldots \ldots \ldots \ldots \ldots \ldots$ & $3 \cdot 0$ & 76 \\
\hline$, \quad, \quad$ supra-orbital foramina $\ldots \ldots \ldots$ & $3 \cdot 9$ & 99 \\
\hline From burr to burr (shortest distance) $\ldots \ldots \ldots \ldots \ldots \ldots \ldots \ldots$ & $5 \cdot 4$ & 137 \\
\hline$, \quad, \quad$ (distance between outer edges) $\ldots \ldots \ldots \ldots \ldots \ldots$ & $10 \cdot 4$ & 265 \\
\hline Top of foramen magnum to top of occipital crest $\ldots \ldots \ldots \ldots \ldots \ldots$ & $3 \cdot 0$ & 76 \\
\hline 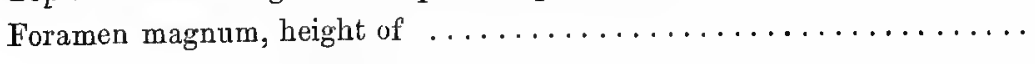 & $1 \cdot 1$ & 28 \\
\hline$\Rightarrow \quad, \quad$ width of $\ldots \ldots \ldots \ldots \ldots \ldots \ldots \ldots \ldots$ & $1 \cdot 4$ & 35 \\
\hline Frontal width, just below pedicles ..... & $7 \cdot 3$ & 185 \\
\hline 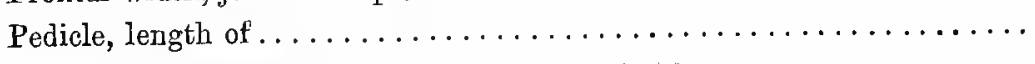 & $1 \cdot 8$ & 46 \\
\hline 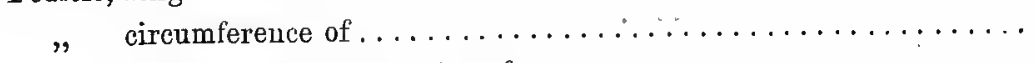 & $8 \cdot 5$ & 215 \\
\hline,$\quad$ antero-posterior diameter of $\ldots \ldots \ldots \ldots \ldots \ldots \ldots \ldots$ & $2 \cdot 4$ & 61 \\
\hline 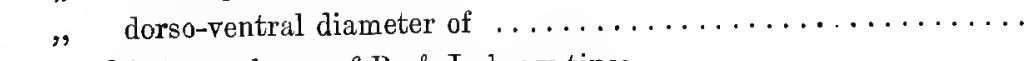 & $2 \cdot 9$ & 74 \\
\hline Interval between bases of $R . \& L$. brow-tines $\ldots \ldots \ldots \ldots \ldots \ldots$ & $9 \cdot \triangleleft$ & 250 \\
\hline 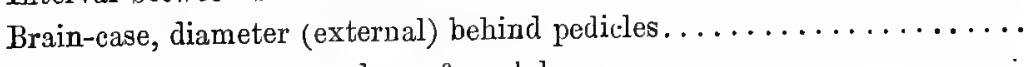 & $4 \cdot 6$ & 117 \\
\hline Distance between onter cdges of condyles $\ldots \ldots \ldots \ldots \ldots \ldots \ldots \ldots$ & $3 \cdot 8$ & 97 \\
\hline
\end{tabular}

1 Pal. Soc., t. cit. pp. 25-28.

2 "La Seine.-I. Le Bassin Parisien. Planches de Paléont.", 1869, p. 1.3. 


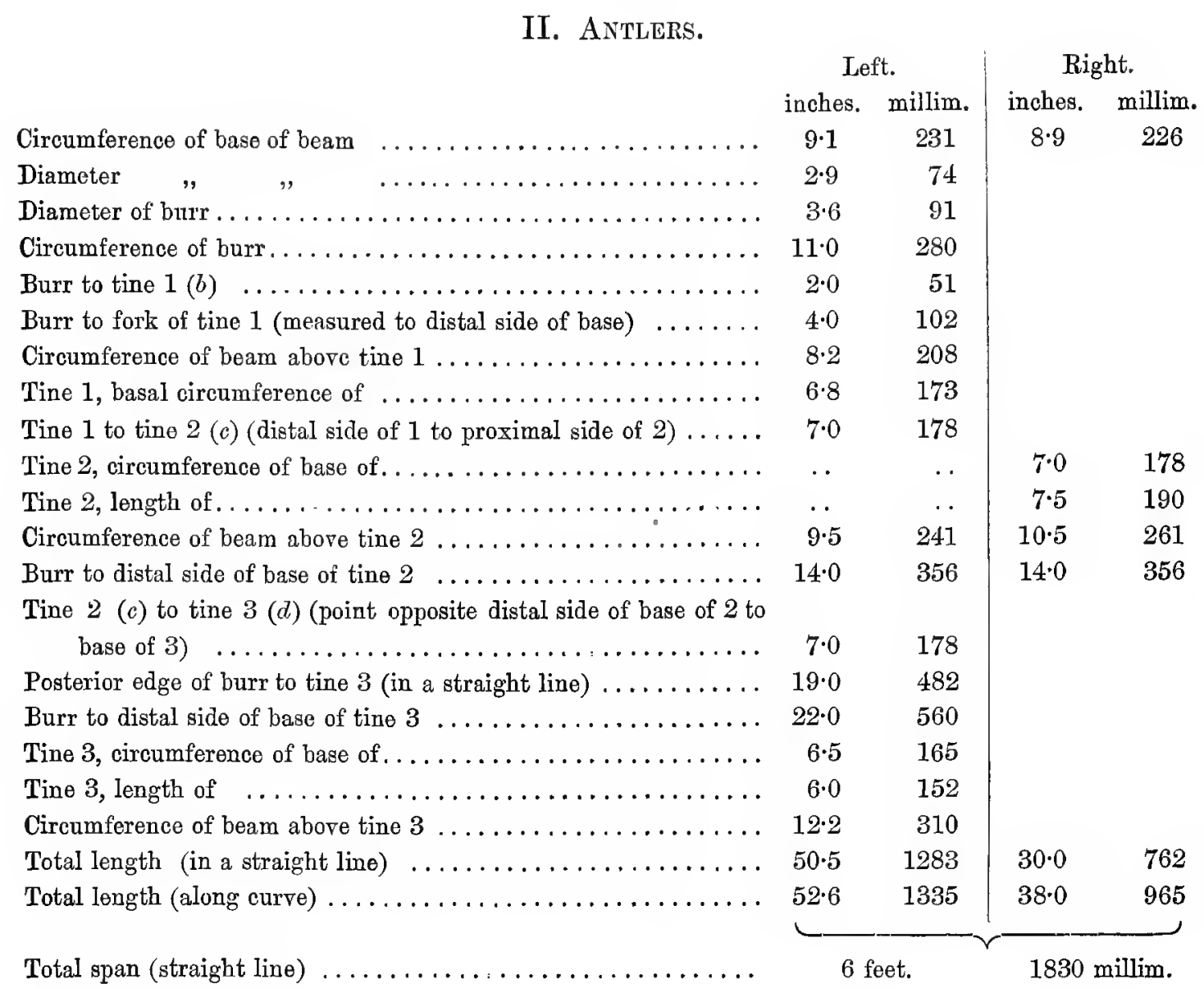

The variability in the position of the tines in this species is illustrated by the following measurements of the interval between tine 1 and tine 2, taken from four other specimens in the Cambridge collection:-

\begin{tabular}{|c|c|c|c|}
\hline $\begin{array}{c}\text { Catalogue No } \\
184 b\end{array}$ & & $\begin{array}{c}\text { inches. } \\
3.5\end{array}$ & $\begin{array}{l}\text { millim. } \\
89\end{array}$ \\
\hline $184 a$ & $\ldots$ & $4 \cdot 0$ & 102 \\
\hline $184 d$ & $\ldots \ldots \ldots \ldots$ & $4 \cdot 5$ & 114 \\
\hline $184 c$ & $\ldots \ldots \ldots$ & $5 \cdot 0$ & 127 \\
\hline
\end{tabular}


III. Atras. (Nearly complete, but wanting the end of the left transverse process. The second series gives the measurements of the articulated specimen of $C$. gigantcus (Irish) in the Woodwardian Museum at Cambridge.)

\begin{tabular}{|c|c|c|c|c|}
\hline \multirow[b]{2}{*}{ Centrum, greatest length of $\ldots \ldots \ldots \ldots \ldots \ldots \ldots \ldots$} & \multicolumn{2}{|c|}{$\begin{array}{l}\text { C. be'grandi } \\
\text { (Pakeield). }\end{array}$} & \multicolumn{2}{|c|}{$\begin{array}{l}\text { C.giganteus (Wood- } \\
\text { wardian Museum). }\end{array}$} \\
\hline & $\begin{array}{l}\text { inches. } \\
2 \cdot 5\end{array}$ & $\begin{array}{l}\text { millim. } \\
\quad 64\end{array}$ & $\begin{array}{l}\text { inches. } \\
2 \cdot 7\end{array}$ & $\begin{array}{l}\text { millim. } \\
68\end{array}$ \\
\hline Neural arch, length in median dorsal line $\ldots \ldots \ldots \ldots \ldots \ldots$ & 25 & 64 & $3 \cdot 0$ & 77 \\
\hline $\left.\begin{array}{l}\text { Greatest width of vertebra (estimated at twice the width of the } \\
\text { perfect side) } \ldots \ldots \ldots \ldots \ldots \ldots \ldots \ldots \ldots \ldots \ldots \ldots \ldots \ldots \ldots \ldots \ldots \ldots \ldots\end{array}\right\}$ & $7 \cdot 3$ & 185 & $8 \cdot 7$ & 221 \\
\hline Width between outer edges of facets for condyles of skull ..... & $4 \cdot 0$ & 102 & $4 \cdot 5$ & 115 \\
\hline Width between outer edges of facets for odontoid process ...... & $4 \cdot 0$ & 102 & $4 \cdot 5$ & 115 \\
\hline $\left.\begin{array}{l}\text { Front edge of facet for condyle to middle of lateral part of facet for } \\
\text { odontoid process } \ldots \ldots \ldots \ldots \ldots \ldots \ldots \ldots \ldots \ldots \ldots \ldots \ldots \ldots \ldots \ldots\end{array}\right\}$ & $4 \cdot 0$ & 102 & $4 \cdot 5$ & 115 \\
\hline $\left.\begin{array}{l}\text { Tip of neural spine to a point vertically below it on the ventral } \\
\text { surface of the centrum } \ldots \ldots \ldots \ldots \ldots \ldots \ldots \ldots \ldots \ldots \ldots \ldots \ldots \ldots\end{array}\right\}$ & $3 \cdot 0$ & 76 & $3 \cdot 6$ & 93 \\
\hline $\begin{array}{l}\text { Tip of hypapophysis vertically to the lerel of the hinder edge of } \\
\text { the neural arch in the middlo line } \ldots \ldots \ldots \ldots \ldots \ldots \ldots \ldots \ldots\end{array}$ & $3 \cdot 0$ & 76 & $2 \cdot 9$ & 74 \\
\hline $\left.\begin{array}{l}\text { Deepest point in the depression behind the ventral nerve-foramen } \\
\text { to the dorsal edge of the facet for the odontoid process......... }\end{array}\right\}$ & $1 \cdot 6$ & 41 & $1 \cdot 8$ & 46 \\
\hline Width of ceutrum between the two depressions $\ldots \ldots \ldots \ldots$ & $1 \cdot 9-2 \cdot 1$ & $47-53$ & $2 \cdot 8$ & 72 \\
\hline Width of neural canal, in front $\ldots \ldots \ldots \ldots \ldots \ldots \ldots$ & $1 \cdot 7$ & 44 & & \\
\hline$" \quad, \quad, \quad$ behind $\ldots \ldots \ldots \ldots \ldots \ldots \ldots \ldots$ & $1 \cdot 7$ & 44 & & \\
\hline Vertical height of neural canal, in frout ... & 12 & 31 & & \\
\hline behind $\ldots \ldots \ldots \ldots \ldots \ldots \ldots$ & $1 \cdot 7$ & 44 & & \\
\hline
\end{tabular}

IV. Axis. (Practically complete.)

Centrum, grcatest length (without odontoid process) $\ldots \ldots \ldots .4$

\begin{tabular}{cc|cc}
\multicolumn{2}{c|}{$\begin{array}{c}\text { C. belyrandi } \\
\text { (Pakefield). }\end{array}$} & \multicolumn{3}{c}{ C.giganteus(Wood- } \\
wardian & Museum). \\
inches. & millim. & inches. & millim. \\
$4 \cdot 4$ & 112 & $5 \cdot 1$ & 129 \\
$5 \cdot 4$ & 137 & & \\
$4 \cdot 0$ & 102 & $4 \cdot 7$ & 120 \\
$5 \cdot 0$ & 127 & $5 \cdot 5$ & 140 \\
$3 \cdot 9$ & 100 & $4 \cdot 4$ & 112 \\
$1 \cdot 6$ & 40 & & \\
$2 \cdot 9$ & 74 & $3 \cdot 2$ & 82 \\
$1 \cdot 6$ & 40 & $1 \cdot 9$ & 48 \\
$5 \cdot 4$ & 137 & $6 \cdot 2$ & 157 \\
$4 \cdot 0$ & 102 & $6 \cdot 8$ & 173 \\
$3 \cdot 0$ & 76 & $4 \cdot 0$ & 102 \\
$1 \cdot 9$ & 48 & & \\
$2 \cdot 4$ & 61 & $3 \cdot 6$ & 92 \\
& & & $\mathbf{Q}$
\end{tabular}




\section{The Affinities of CervUs belgrandi.}

It is now generally accepted that the Irish Deer (C. giganteus) ${ }^{l}$ and its allies are members of the Damine group. The particular position which $C$. belgrandi should occupy in this group has not hitherto received adequate consideration, in consequence of the imperfect condition of all the previously described examples. It appears to me that Cervus belgrandi combines in a most interesting manner the characters of C. dama and its fossil allies (C. browni, \&c.) and of the series of forms including the Irish Deer. Many specimens of $C$. dama agree precisely with $C$. belgrandi in the number and position of the tines and in the general character of the palmation. The principal differences between the two forms are: (1) the more horizontal position of the beam in $C$. belgrandi; (2) the position and characteristic downward curve of the first tine in that species; and (3) the existence of a scalloped edge of the crown in C. belgrandi, as distinguished from that of $C$. dama, which is prolonged into more definite tines. Both species agree in the absence of points on the anterior edge of the crown. 'The palmated region includes the back-tine in C. dama, whereas in $C$. belgrandi there is a distinct constriction between the back-tine and the palmation. 'The comparative suddenness with which the expansion begins in this species is probably the reason why its real character has not hitherto been suspected.

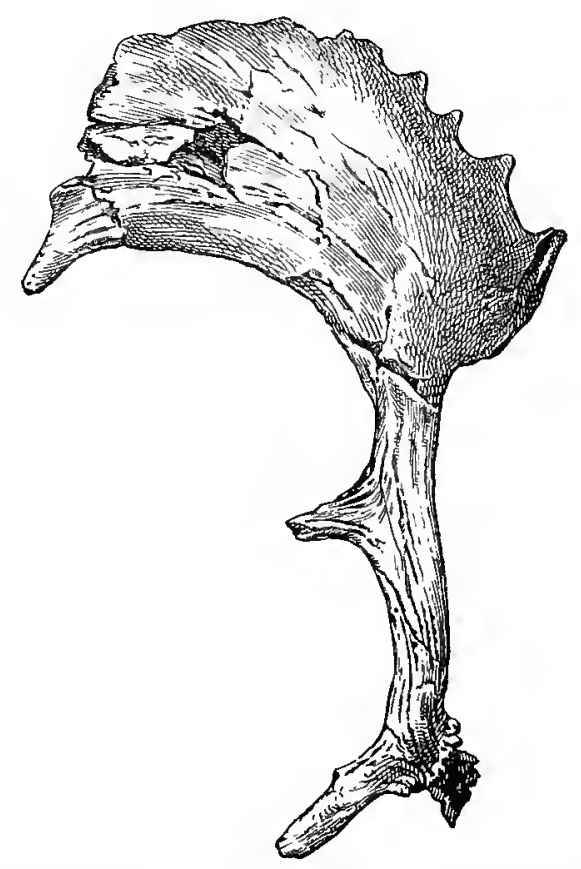

Right antler of Cervus dama, believed to be of preglacial age, from Belzig, 10 miles S.W. of Berlin; seen from the inner side. (After Keilhack.)

3 'Mannel d'Hist. Nat., traduit de l'allemand de J. F. Blumenbach,' ji. 1803, p. 407. 
A most interesting specimen, referred to Cervus dama, has been described by Keilhack ${ }^{1}$ from Belzig, 10 miles south-west of Berlin. It would not be easy to find a specimen affording a more complete transition from $C$. belgrandi to the modern $C$. dama than this one, and I have accordingly reproduced one of Keilhack's figures of the right antler (woodcut, p. 104). The specimen far exceeds in size all the Fallow-deer measured by Keilhack, the base of the beam being no less than $180 \mathrm{~mm}$. in circumference, as compared with $132 \mathrm{~mm}$., the mean of the measurements of the recent individuals given by the same author. It further approaches $C$. belgrandi in the scalloped edge of the posterior part of the palmation and in the downward curvature of the large brow-tine, which, however, originates immediately above the burr. The brow-tine appears from the figures to spring from the beam somewhat on its posterior side, as in the Forest-Bed form. 'The affinity of Keilhack's specimen to C. dama is, however, shown by the angle made by the antlers with the skull, the direction being much less horizontal than in C. belgrandi, and by the inclusion of the back-tine in the palmation, from which it projects in much the same way as in the recent Fallow-decr. The beam terminates in a short but distinct snag at the distal and anterior edge of the crown, but the interval between this and the back-tine has a scalloped edge closely resembling that of the Pakefield specimen. Nehring ${ }^{2}$, in remarking on the Belzig specimen, in a paper which preceded Keilhack's memoir, expresses the opinion that it must be regarded, if not as an actual C. dama, at least as a direct ancestor of that species.

The Belzig specimen indicates in the clearest way the probable derivation of the modern $C$. dama from forms resembling $C$. belgrandi, the principal changes which have talsen place being apparently the diminution in size, the approximation of the crowns of the two antlers by the assumption of a less horizontal position, the inclusion of the back-tine in the palmation, and the replacement of the serrations of the crown by the snags which characterize the recent Fallow-deer. The discovery of the Balzig specimen and that of the form here described go far towards filling up the gap between C. giganteus and C. dama, to the existence of which attention is called by Rütimeyer ${ }^{3}$, in insisting on the affinity of these two forms. It may be noted that the immature antlers ${ }^{4}$ of $C$. dama have the posterior edge of the crown denticulated in a way strikingly suggestive of $C$. belgrandi.

The resemblance of $C$. belgrandi to $C$. giganteus is no less striking. Pohlig ${ }^{5}$ has

${ }^{1}$ K. Keilhack, " Ueber einen Damhirsch aus dem deutschen Diluvium," Jahrb. k. Preuss. geolog. Landesanstalt (1887), 1888, p. 283, pl. xi.

2 "Ueber das fossile Vorkommen ron Cervus dama .... in Norddeutschland," SB. Ges. naturf. Berlin, 1883 , p. 69 .

3 " Beiträge zu einer natürlichen Geschichte der Hirsche," Abhandl. Schweiz. pal. Gesellsch. x. 1883, 1. 111.

" Of. Cuvier, "Recherches sur les Ossemens Fossiles," 3rd ed. t. iv. 1825, pl. iii. figs. 28, 29.

5 “Die Cerviden des thüringischen Diluvial-Travertines, mit Beiträgen ïber andere diluviale und über recente Hirschformen," Palæontographica, xxxix. 1892, p. 215. 
recently defined several forms of the latter species, which are accepted with certain modifications by Lydekker '. 'Taking the nomenclature of the latter, we have

1. Cervus giganteus carnutorum Laug., of which C. verticornis is regarded as a synonym. C. verticornis occurs typically in the Forest-Bed (early Pleistocene), and C. carnutorum in beds of equivalent age in France. Boyd Dawkins records the occurrence of one specimen of C. verticornis in the Pliocene (Red Crag).

2. C. giganteus belgrandi Lart., from the Mid-Pleistocene of France and Germany.

3. C. giganteus italice Pohl., from similar and later deposits of Italy, Hungary, \&c.

4. C. giganteus ruffi Nehr. (=C. euryceros germanice Pohl.), the typical German race, found also in other parts of the Continent and in England, contemporaneously with the Cave-Bear, although first recorded from the Mid-Pleistocene.

5. C. giganteus typicus Lyd. (=C. euryceros hibernia Pohl.), the Irish Deer, the most recent form.

The conclusion that $C$. verticornis is a synonym of $C$. carnutorum appears to me in the highest degree doubtful. The latter, found at Saint-Prest, near Chartres, was described by Laugel ${ }^{2}$ from some upper molars, some portions of the antlers, a metatarsal, and a lumbar vertebra, which were all believed to belong to one species, comparable in point of size with the Irish Deer. Laugel does not figure the antlers, but he calls attention to the fact that their bases are remarkably approximated. The crown was probably palmated, and is believed to have borne about five curved snags, the longest of which measured $26 \mathrm{~cm}$. These characters are quite sufficient to show the difference between Laugel's species and $C$. verticornis, even without the illustrated account of the Saint-Prest fossils which has been given by Gervais ${ }^{3}$. From this memoir it appears that the vertex of the skull of $C$. carnutorum is much raised, so as to resemble that of the "Antilope Bubale"; this being an important difference between it and the Forest-Bed Stag. The antlers are closely approximated at their bases ( $c f$. pl.xvi. fig. 4 of Gervais) and diverge from one another at an acute angle. An equally striking feature of this species is that, when looked at from in front, the brow-tine appears to originate from the outer outline of the beam, while that of $C$. belgrandi, viewed from the same aspect, appears to spring from the inner outline.

Professor Boyd Dawkins and Mr. E. T. Newton ${ }^{4}$ have, however, referred several fragments from the Norwich Crag, and possibly from the Forest-Bed, to C. carnutorum. I am not prepared to express any opinion with regard to these specimens.

I am indebted to Professor Boyd Dawkins for a letter in which he informs me that he is inclined to regard his Cervus verticornis (1872) as identical with $C$. belgrandi (Lartet) Belgrand (1869), and for the further information that the type-specimens of the latter are no longer in existence. C. belgrandi was described in Belgrand's work

1 T. cit. pp. 134-141. $\quad 2$ Bull. Soc. Géol. France, (2) xix. 1862, p. 711.

3 “Zool. et Paléont. Générules.-Nouv. Recherches sur les Vertébrés Vivants et Fossiles," 1e sér. 1867-1869, p. 84, pl. xri. figs. $3-8$.

4 For references, see E. T. Newton, "The Vertebrata of the Pliocene Deposits of Britain," Mem. Geol. Survey, 1891, p. 26. 
"La Seine" ", parts of two frontals, with the bases of the antlers, being figured. These fossils appear to me to agree in all essential respects with the Pakefield specimen. The inclination of the antlers, the distance from one another of the pedicles, and in particular the position of the brow-tine agree in the two forms; the measurements correspond with a sufficient degree of accuracy; while it further appears from Belgrand's plate xix. that the second tine of Cervus belgrandi does not originate in the same line with the brow-tine, but at a point $90^{\circ}$ further forward than the line containing the base of the brow-tine, in exactly the way that is characteristic of C. verticornis. Polilig ${ }^{2}$ regards the rudimentary condition of the brow-tine as a leading characteristic of C. belgrandi. Had he, however, copied Belgrand's representation of the right antler in pl. xviii., instead of that of the left antler, this condition would have been much less apparent; and in the specimen ${ }^{3}$ from Taubach which he himself figures (pl. xxiv. fig. 1) the brow-tine has essentially the characters of that of the Forest-Bed form.

Cervus giganteus italia also shows some interesting resemblances to the Forest-Bed form. The specimens in the Museums of Milan and Arezzo figured by Pohlig ${ }^{4}$ have a palmated crown which shows a distinct resemblance to the Pakefield specimen, from which they differ, however, in the larger development of the points of the crown and in having the brow-tine in the position characteristic of the typical $C$. giganteus. Part of the definition of this form given by Lydekker-the upward inclination of the palmation. the front border of which is curved inwardly so that much of the outer surface is seen in a front view, and the occurrence of the points of the crown near the summit of the palmation-will apply equally well to $C$. belgrandi. The general direction of the antlers, the beams of which spread out at first nearly horizontally, the palmated part then curving upwards, is again strikingly suggestive of that form.

C. megaceros ruffii was named and figured by Nehring ${ }^{5}$, who calls attention to the absence of points on the anterior edge of the palmated part as an indication of affinity to $C$. dama. Although agreeing in this respect with $C$. belgrandi, it has already acquired long tines springing from the distal border of the crown in a manner suggestive of the Irish Deer. Some of the specimens of this race, for instance that from the Worms Museum figured by Pohlig (p. 222, figs. $4 c$ and $4 d$ ), show a much closer approach to the Forest-Bed species, in the way in which the crown is set on to the beam and in the slight development of the terminal snags.

The general conclusion seems to be that $C$. belgrandi is the most central type of the Giant Deer, showing as it does a distinct affinity to the Fallow-deer as well as to the

1 “ Hist. Gén. de Paris. La Seino.-T. Le Bassin Parisien,” par E. Belgrand. 'Planches de Paléontologie,' 1869 , p. 13 , pls. xviii.-xx.

${ }^{3}$ I do not feel convinced that this really belongs to C. belgrandi.

2 T. cit. p. 232.

T. cit. p. 228.

5 "Über eine besondere Riesenhirsch-Rasse aus der Gegend von Kottbus," Sitzungsber. Ges. naturf. Fr. Berlin, 1891, p. 151. See also papers by the same author, "Neue Notizen über Cervus megaceros, var. ruffi, Nhrg.," ibid. 1892, p. 3 ; and 'Deutsche Jäger-Zeitung,' xxxii. 1899, p. 681 ; xxxiii. 1899, p. 413.

VOL. XV.-PART IV. No. 4.-December, 1899. 
Cervus gigantens series. The large size of the Pakefield specimen and the condition of the sutures of the skull preclude the idea that it can be a young form, and there is every reason to suppose that the characters shown by it are those of the adult animal. The crown has become conspicuously palmated, but the long tines found in C. giganteus are at present indicated merely by a slight serration of its distal border. Another point which seems to me to deserve special notice is the direction of the vascular grooves on the beam of the antler. In the Forest-Bed specimens these run in an accurately longitudinal course up the posterior and ventral surface of the beam, while in the Irish Deer, as well as in the specimens of $C$. giganteus from the Barrington gravel, the grooves have an elongated spiral course. This may indicate a torsion of the whole antler. It is a noteworthy fact that the palmated crown of the Irish Deer is much more horizontally placed than that of $C$. belgrandi, in which the direction is very oblique, the dorsal surface looking somewhat backwards. If the anterior edge of the crown in $C$. belgrandi were depressed by the torsion of the beam, so as to bring the palmation into a horizontal position, this new position would not only agree with that found in the Irish Deer, but it would result in a torsion of the vascular grooves, which would thereupon assume the spiral course characteristic of the latter. C. dama agrees with the Irish Deer in this respect. Although the brow-tine of the Irish Deer may have the same curvature at its base as that in $C$. belgrandi, it comes off immediately above the burr and from the extreme front edge of the beam. 'The second tine of the Irish Deer is more nearly opposite the back-tine than in $C$. belgrandi, and the palmation often begins soon enough to include it, instead of commencing above the back-tine, as in that species.

The geological occurrence of $C$. belgrandi agrees well with the conclusion above indicated. Its occurrence in the Forest-Bed is itself an evidence of its relative antiquity, while the existence of the species in the Red Crag (Boyd Dawkins) carries this form further back than any of the other races of Giant Deer.

\section{EXPLANA'THON OF PLA'TE XXI.}

Fig. I. Cervus belgrandi.-Skull and antlers, from behind. $\times \frac{1}{7}$. The specimen was obtained at Pakefield, near Lowestuft. $a$, burr ; $b$, first tine; $d, d^{\prime}$, back-tine. The tines $c$, which are not visible in this position, come off from the front edge of the beam, midway between $b$ and $d$.

Fig. 2. View of the same specirnen from the right side. The figure having been drawn from a photograph, the parts of the right antler appear much larger than they really are. $b$, first tine ; $c$, second tine; $d$, $d^{\prime}$, back-tine.

Fig. 3. Atlas vertebra of the same specimen, from the ventral side. 'The end of the right transverse process is partially obscured by the matrix.

Fig. 4. Axis vertebra of the same specimen, from the right side. 'The end of the neural spine is partially obscured by the matrix. 


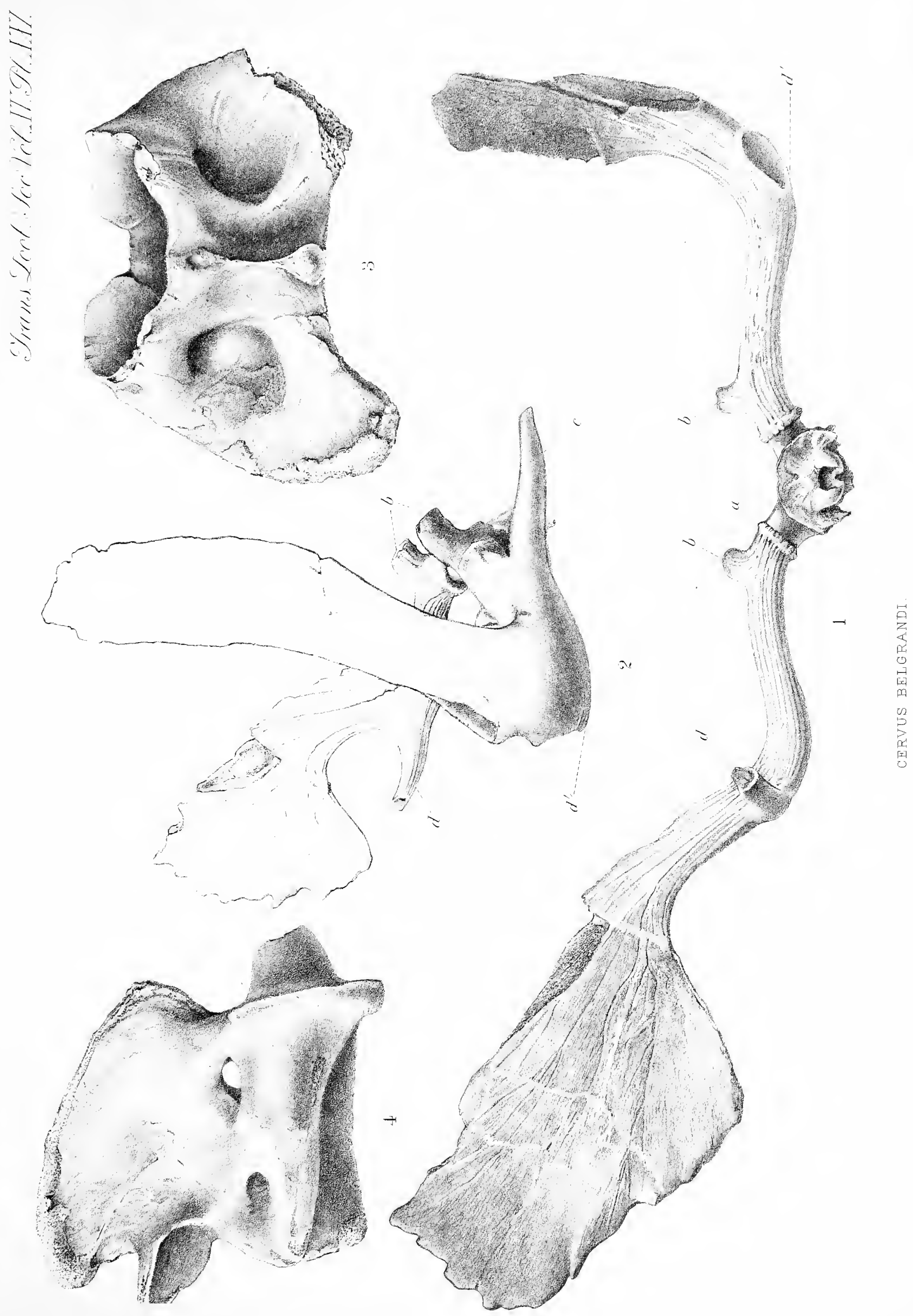

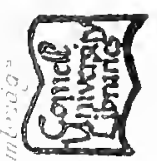





\section{TRANSACTIONS OF THE ZOOLOGICAL SOCIETY OF LONDON (continued).}

\begin{tabular}{|c|c|c|c|c|c|c|c|c|c|c|c|c|c|}
\hline & & & & & & & & o Fello & OWs. & & & To the $\mathrm{Pu}$ & tblic. \\
\hline & & & & & & & & & & & & $£ s$. & $d$. \\
\hline VOLUME XIII. (1891-1895, & containing & & Plat & tes) & & . $I$ & Price 6 & 68 & 3 & 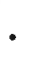 & & . 811 & 0 \\
\hline PART 1. (1891, containing & 6 Plates) & - & - & - & - & . & , 0 & 015 & 9 & & - & 11 & 0 \\
\hline "2. (1891, containing & 6 Plates) & • & 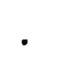 & . & . & . & " & 015 & 9 & & - & 1 & 0 \\
\hline 3. (1891, containing & 6 Plates) & - & 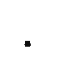 & . & . & . & " & 018 & 0 & & . & 1 & 0 \\
\hline "4. (1892, containing & 1 Plate). & . & . & . & . & . & " & 0.4 & 6 & & . & 6 & 0 \\
\hline „5. (1893, containing & 9 Plates) & . & . & . & . & . & , & 011 & 3 & & . & 015 & 0 \\
\hline , 6. $(1893$, containing & 4 Plates) & - & & . & - & . & $\eta$ & $\begin{array}{ll}0 & 9\end{array}$ & 0 & & - & 012 & 0 \\
\hline , 7. $(1893$, containing & 6 Plates) & - & $\cdot$ & - & . & . & , & 09 & 0 & & - & 012 & 0 \\
\hline " 8. (1894, containing & 6 Plates) & - & . & $\therefore$ & . & . & , & 09 & 0 & & . & 012 & 0 \\
\hline "9. (1894, containing & 6 Plates) & . & . & - & - & - & 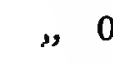 & 011 & 3 & & • & 015 & 0 \\
\hline „10. (1895, containing. & 5 Plates) & & & • & & . & $"$ & 09 & 0 & & & 012 & 0 \\
\hline „11. (1895, containing & 7 Plates a & ad 7 & Title & an & & Indes & $\Rightarrow 0$ & 015 & 9 & & & 11 & 0 \\
\hline
\end{tabular}

VOLUME XIV. (1896-1898, containing 47 Plates) . Price $5 \quad 5 \quad 0 \quad . \quad . \quad . \quad 7 \quad 0 \quad 0$

PART 1. (1896, containing 2 Plates) . .... . . $\quad \begin{array}{llllllllll}0 & 6 & 0 & . & . & 0 & 8 & 0\end{array}$

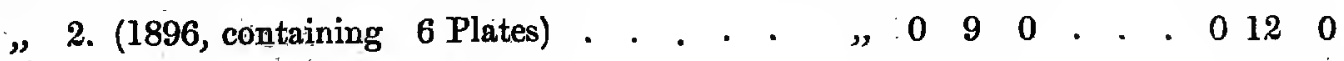

„3. (1897, containing 9 Plates) . . . . . $\quad 0 \begin{array}{llllllll} & 0 & 15 & 9 & . & 1 & 0\end{array}$

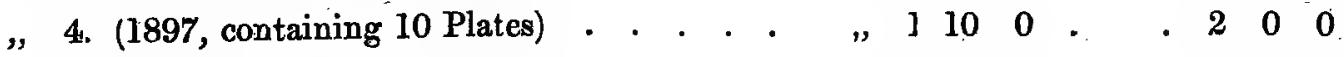

„5. (1898, containing 2 Plates) . . . . . $\quad$ ” 0

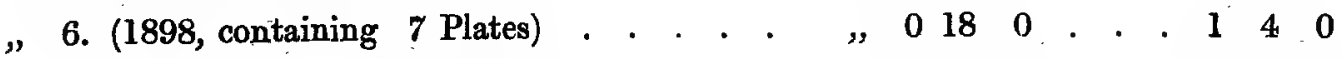

"7. (1898, containing 6 Plates) . . . . . $\quad$, 0113 . . . 0150

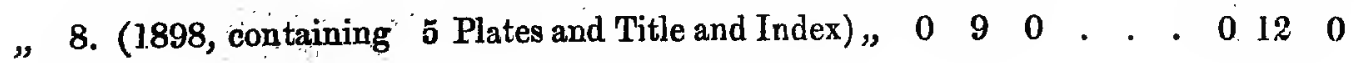

\section{VOLUME XV.}

Part 1. (1898, containing 8. Plates) . . . . . . Price 015 9 15 . . 110

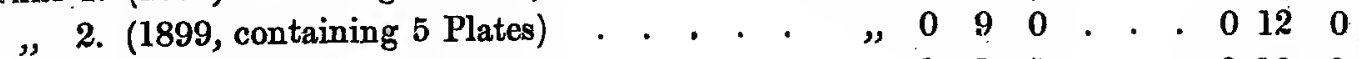

y. 3. (1899, containing 4 Plates) . . . . . . $\quad \begin{array}{lllllllllll} & 0 & 9 & 0 & . & . & . & 0 & 12 & 0\end{array}$

"4. (1899, containing 4 Plates) . . . . . $\quad$, $0 \begin{array}{llllllllll}0 & 9 & 0 & . & . & 0 & 12 & 0\end{array}$ 


\title{
CONTENTS.
}

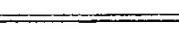 \\ IV: Second Contribution to the Ichthyology of Lake Tanganyika.-On the Fishes \\ obtained by the Congo Free State Expedition under Lieut. Lemaire in 1898. \\ $B y$ G. A. Boulenger, F.R.S., F.Z.S. (Plates XVIII.-XX.) . . . page 87 \\ V. On a Specimen of Cervus belgrandi Lart. (C. verticornis Dawk.) from the Forest- \\ Bed of East Anglia. By Sịney F. HARMer, Sc.D., F.R.S., Superintendent of \\ the University Museum of Zoology, Cambridge. (Plate XXI.) . . , page 97
}

THE PUBLICATIONS OF THE ZOOLOGICAL SOCIETY OF LONDON.

THE scientific publications of the Zoological Society of London are of two kinds- "Proceedings," published in an octavo form, and "Transactions," in quarto.

According to the present arrangements, the "Proceedings" contain not only notices of all business transacted at the scientific meetings, but also all the papers read at such meetings and recommended to be published in the "Proceedings" by the Committee of Publication. A large number of coloured plates and engravings are attached to each annual volume of the "Proceedings," to illustrate the new or otherwise remarkable species of auimals described in them. Among such illustrations, figures of the new or rare species acquired in a living state for the Society's Gardens are often given.

The "Proceedings" for each ycar are issued in four parts, on the first of the months of June, August, October, and April, the part published in April completing the volume for the preceding year.

The "Transactions" contain such of the more important communications made to the scientific meetings of the Society as, on account of the nature of the plates required to illustrate them, are better adapted for publication in the quarto form. They are issued at irregular intervals.

Fellows and Coxesponging Members, upon payment of a Subscription of $£ 11 s$, before the day of the Anniversary Meeting in each year, are entitled to receive all the Society's Publications for the year. They are likewise entitled to purchase the Publications of the Society at 25 per cent. less than the price charged for them to the Public. A further reduction of 25 per cent. is made upon purchases of Publications issued prior to 1871, if they exceed the value of five pounds.

Fellows also have the privilege of subscribing to the Annual Volume of the 'Zoological Record" for a sum of $\$ 1$ (which includes delivery in the United Kingdom only), but this privilege only holds good if the subscription is paid before the First of December in each year.

Such of these publications as are in stock may be obtained at the Society's Office (3 Hanover Square, W.), at Messrs. Longmans', the Society's publishers (Paternoster Row, E.C:), or through . any bookseller.

Decenber 1899.

P. L: SCLATER, Secretary. 


\title{
TRANSACTIONS
}

OF

\section{THE ZOOLOGICAL SOCIETY \\ OF LONDON.}

Vol. XVI.-Part 3.

\author{
LONDON : \\ PRINTED FUR THE SOCIETY,
}

SOLD AT THEIR HOUSE IN HANOVER-SQUARE;

AND BY MESSRS. LONGMANS, GREEN, AND. CO., PATERNOSTER-ROW

October 1901.

Price 21s.

Recd.Noun-27,19M. cain

Taylor and Francis, Printers,] 


\title{
TRANSACTIONS OF THE ZOOLOGICAL SOCIETY OF LONDON.
}

\author{
To Fellows. To the Public. \\ $£$ s. $d$. $\quad \&$ s. $\dot{d}$. \\ VOLUME I. (1833-1835, containing 59 Plates) . . Price 3136 . . : 418 0* \\ VOLUME II. (1835-1841, containing 71 Plates) ., $\begin{array}{lllllll}4 & 0 & 0 & & 5 & 6 & 6^{*}\end{array}$ \\ VOLUME 1II. (1842-1849, containing 63 Plates). $\quad$, $\quad \begin{array}{rlrrr}3.8 & 3 & 4 & 11 & 0^{*}\end{array}$

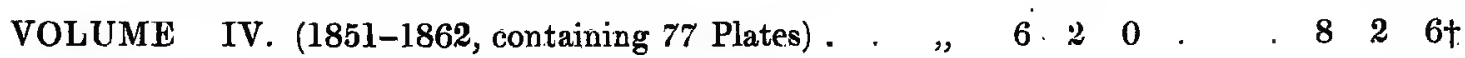 \\ VOLUME V. (1862-1866, containing 67 Plates) . . " " $\quad \begin{array}{lllllllll}5 & 4 & 3 & . & 6 & 19 & 0\end{array}$ \\ VOLUME VI. (1866-1869, containing 92 Plates). $\quad \begin{array}{lllllllllll} & 11 & 5 & 0 & . & . & 15 & 0 & 0 & 0\end{array}$ \\ VOLUME VII. (1869-1872, containing 73 Plates). $\quad \begin{array}{lllllll} & 10 & 4 & 0 & .13 & 12 & 0 \dagger\end{array}$ \\ VOLUME VIII. (1872-1874,-containing 82 Plates). $\quad \begin{array}{lllllllllll} & 9 & 8 & 3 & . & . & 12 & 11 & 0\end{array}$

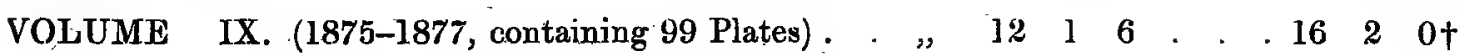 \\ VOLUME $\quad X$. (1877-1879, containing 95 Plates) . . ” $\quad 10 \begin{array}{llllllll}10 & 0 & 3 & . & 13 & 7 & 0\end{array}$

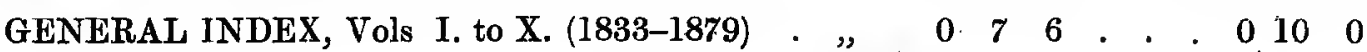 \\ VOLUME XI. (1880-1885, containing 97 Plates) . . " $\begin{array}{llllllllll} & 9 & 12 & 0 & . & . & 12 & 16 & 0\end{array}$ \\ VOLUME XII. (1886-1890, containing 65 Plates) . . „ „ $\begin{array}{llllllllll} & 5 & 8 & 0 & . & . & 7 & 4 & 0\end{array}$ \\ VOLUME XIII. (1891-1895, containing 62 Plates) . .,$\quad \begin{array}{lllllllll}6 & 8 & 3 & . & . & 8 & 11 & 0\end{array}$ \\ * No copies of these volumes remain in stock. \\ $\dagger$ Only complete copies of these volumes are left in stock.
}




\section{$\left[\begin{array}{ll}137 & ]\end{array}\right.$}

IV. Third Contribution to the Ichthyology of Lake Tanganyika.-Report on the Collection of Fishes made by Mr.J. E.S. Moore in Lakes Tanganyika and Kivu during his Second Expedition, 1899-1900. By G. A. Boulenger, F.R.S., F.Z.S.

Received and read January 15, 1901.

\section{[Plates XII.-XX.]}

IN presenting this report on the second collection made in Lake Tanganyika by Mr. Monre 1, I may at once state that the expectations held out in the first report, as to the possible occurrence, in the greater depths of the lake, of forms differing fundamentally from the typically African freshwater forms, have not been in any way realized. Although fully equipped for a complete survey of the lake, both on its shores and in its depths, which we know to extend beyond 300 fathoms, the Tanganyika Expedition organized by Professor Ray Lankester has failed to bring home representatives of any but the few families already known from the lake, and which occur also in the other basins of Tropical Africa ${ }^{2}$. Its results only further emphasize the striking fact of the extraordinary multitude and diversity of the Cichlid

1 For an account of the Expedition, ef. Geographical Journal, vol. xvii. 1901, p. 1.

${ }^{2}$ Since the publication of the first report, in which lists were given of the fishes of the principal lakes of Central Africa, the ichthyological fauna of Lake Mweru, which, from its vicinity to Tanganyika, is of special interest, has become known through collections made by Mr. Alfred Sharpe, C.B., and the Lemaire Expedition (Congo Free State). It enables me to draw up the following list, in which the names of the endemic species are printed in italic, the general habitat of the others being given in brackets :-

\section{MormXridas.}

1. Gnathonemus stanleyanus Blgr. (Congo).

2. Mormyrus longirostris Peters (Nile, Congo, Zambesi).

\section{Characinide.}

3. Hydrocyon lineatus Blkr. (Senegal to Congo, Tanganyika, Zambesi).

4. Alestes macrophthalmus Gthr. (Gaboon, Ogowe, Congo, Tanganyika).

5. Alestes lemairii Blgr.

SILURIDAE.

6. Schilbe mystus L. (?) (Nile, Calabar, Congo).
7. Chrysichthys sharpii Blgr.

8. Auchenoglanis biscutatus Geoffr. (Nile, Trop. Africa).

9. Synodontis zambesensis Ptrs. (Zanzibar to Mozamlique, Nyasa).

10. Synodontis ornatipinnis Blgr. (Congo).

\section{Cichlid ze.}

11. Paratilapia macrocephala Blgr.

12. Paratilapia mocruensis Blgr.

13. Tilapia natalensis M. Web. (Congo, E. \& S.E. Africa).

14. Tilapia polyacanthus Blgr. voL. XVI.-PART III. No. 1.-October, 1901. 
Perciform Fishes, a very natural group the habitat of which extends over the fresh waters of the whole of Africa, Madagascar, South-western Asia, Southern India and Ceylon, and Central and South America. They also confirm the no less remarkable negative feature of the absence of Mormyrids, a family so eminently characteristic of the Ethiopian fresh waters, occurring as they do in all the rivers of Tropical Africa, and in all the lakes north and south of Tanganyika. Lastly, they add to the list of Cyprinids, and bring out the interesting fact of the presence in that lake of a species of Capoëta, which genus, well represented in Southern Asia, was known in Africa from a single species inhabiting Abyssinia. But the general conclusions which could be drawn from the study of the first collection require no modification.

An important addition has been made to our knowledge of the Central-African lakes through Mr. Moore's investigation of Lake Kivu, to the north of Tanganyika, and overflowing into the latter through the Rusisi River, but without any communication with any other basin, and this investigation has failed to throw any light on the problem of the halolimnic fauna. With regard to the piscine inhabitants of Kivu, the information gained goes simply to show that its waters are very thinly populated. Its former connection with the Nile, at probably no very remote period, geologically speaking, as ascertained by the Expedition, may account for the presence of Tilapia nilotica, a species which has not been found in the Tanganyika nor in the Congo Basin. Along with it were obtained examples of another Tilapia (T. burtoni) previously known from Tanganyika, a Paratilapia ( $P$. bloyeti) described from East Africa, a new species of the same genus, and a new Barbus. No representatives could be found of any of the numerous generic types of Cichlides which are the essential feature of the fish-fauna of the great lake.

The number of specimens brought home on this occasion from Tanganyika and Kivu amounts to 190, representing 50 species, 26 of which were new to science, obtained at the following localities, enumerated from south to north, as well as from far out in Lake Tanganyika:-

Kinyamkolo, extreme south end of Lake Tanganyika.

Kalambo, S.E. of lake.

T'embwi, W. coast, 35 or 40 miles S. of Albertville.

Msambu, E. coast, S. of middle.

Kibogo, E. coast, middle of lake.

Kibwesi, near Kibogo.

Maswa, E. coast, about 50 miles S. of Ujiji.

Usambura, N. end of lake.

Rusisi $R$., at month.

Rusisi R., at source.

L. Kivu.

In the introduction to the first Report, I tabulated the species then known from 
Lake Tanganyika and made np a list of 43 species. Through the collections formed since by the Officers of the Congo Free State and by Mr. Moore, the number has now risen to 91 -that is, nearly as many as are known from the Nile (anadromous and catadromous species not included). Out of these 91 species it has been my privilege to describe as many as 74 , and I beg on this occasion to express my most grateful thanks to my friend $\mathrm{Mr}$. Moore, and to my fellow-countrymen in the service of the Congo Free State, for having placed in my hands the valuable material brought home at the cost of so great perils and hardships.

\section{List of the Fishes of Lakes Tanganyika and Kivil.}

The names of the genera and species peculiar to these lakes are printed in italic, the others in roman, in the Table (pp. 140-141).

The 7 columns refer to the various collections on which the list is based :-

1. Mr. Coode Hore's Collection (Günther, P. Z. S. 1893, p. 628).

2. Mr. Moore's first Collection (Boulenger, Tr. Zool. Soc. xv. 1898, p. 1).

3. Capt. Descamps's Collection (Boulenger, l. c.).

4. Lieut. Lemaire's Collection (Boulenger, op. cit. 1899, p. 87).

5. Capt. Hecq's Collection (Boulenger, Ann. Mus. Congo, Zıol. i. 1899 \& 1900).

6. Mr. Moore's second Collection from Tanganyika.

7. Mr. Moore's Collection from Kivu.

In the eighth column the range outside the Tanganyika district is indicated.

The following deductions may be drawn from the Table:-

1. Endemic genera occur only in the family Cichlidce, but these are remarkably numerous (17), nearly equalling in number those known from all other parts of the world.

2. Most of the species of Cichlides and all the Cyprinidce and Mastacembelidas are endemic, whilst all the Characinida and one-half the Siluridoe have a much wider range.

3. Not one of the collections yet made contains representatives of much more than one-half of the known species ${ }^{1}$, and out of the six species represented in the first collection (Mr. Coode Hore's) only three hare been rediscovered.

\footnotetext{
1 Mr. Moore wishes me to observe, however, that, owing to the difficulties of transport, he abstained in many cases from preserving specimens of the species which he felt certain of having obtained on his first expedition. The fact nevertheless remains that the collections made by him are so far from being duplicated by those received from the Belgian explorers as to show our knowledge of the Fishes of the lake to be still far from complete. Although Mr. Moore fished not far from Albertville, it is surprising how many species discovered about the latter place by Capt. Hecq are nnrepresented in his collection. He also fished near Ujiji, and yet examples of only two ont of the six species described by Dr. Giinther from Mr. Coode Hore's collection have turned up again.
} 


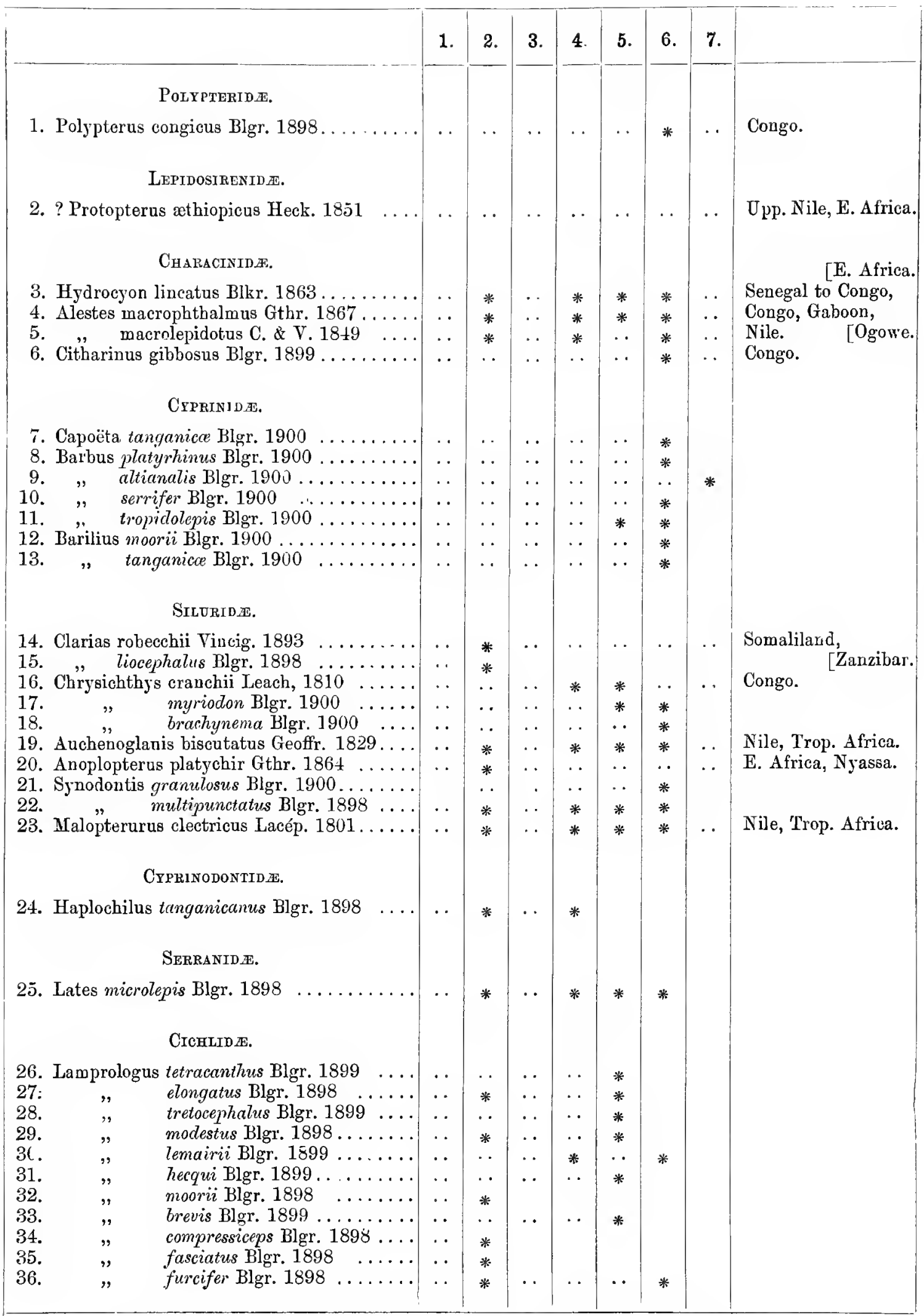




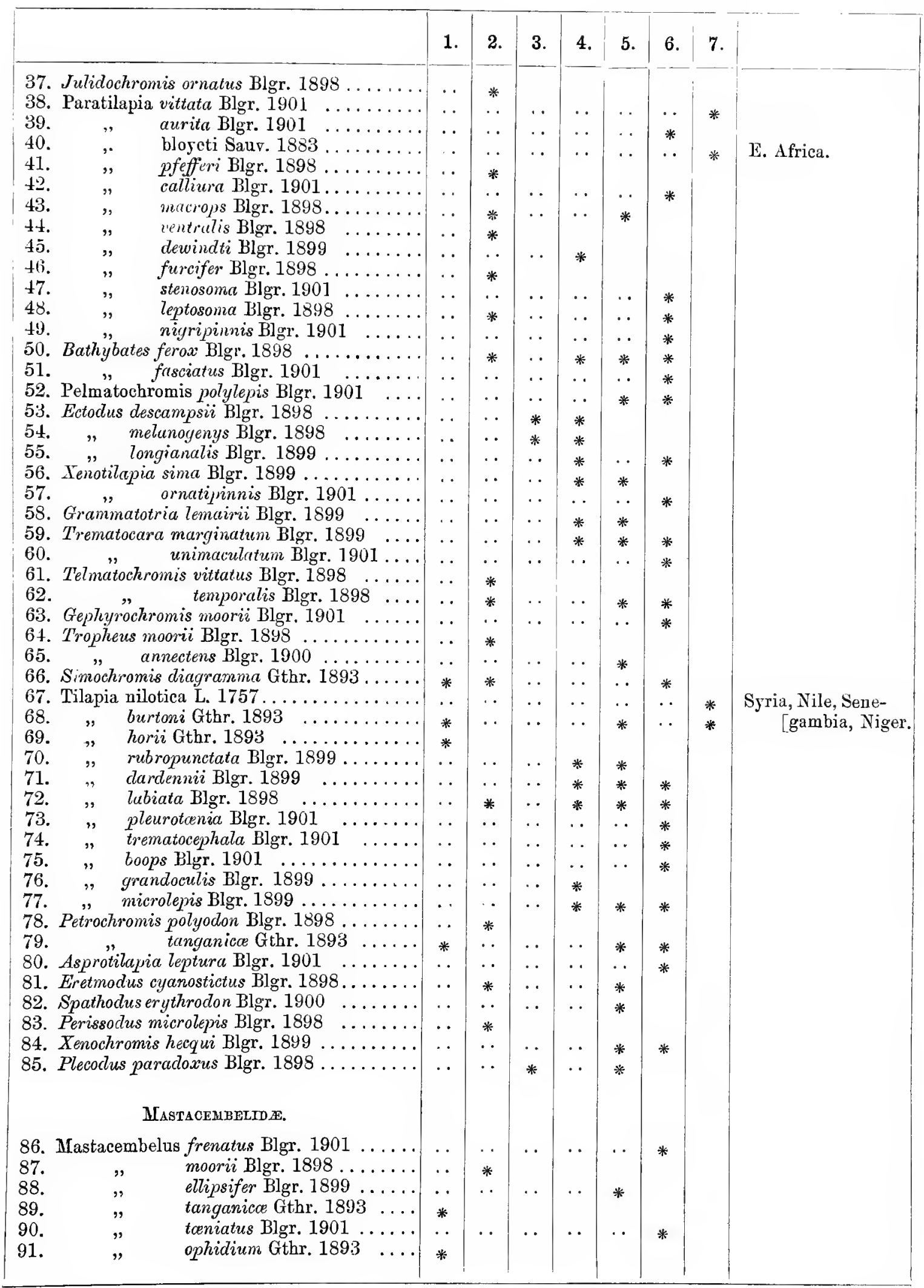


I am therefore disposed to conclude that we do not know much more than one-half of the species which will ultimately be found to inhabit Lake Tanganyika.

As regards facts of distribution, I can only emphasize again the quite extraordinary abundance and variety of the Cichlid $x$, the salient feature of the Lake which might be named the kingdom of the Cichlidas: 60 species (divided into 21 genera), being more than are known from the whole of the rest of Africa (including Madagascar) with Syria, and about as many as can be listed from South America.

As to the affinity shown by the Tanganyika Fish-fauna to other basins of Africa, we may at once dismiss all connection with Nyasa and the Zambesi. Of the genera that are not ubiquitous in Tropical Africa, two (Capoëta and Anoplopterus) have representatives in East Africa only, and two (Lamprologus and Pelmatochromis) in the Congo and West Africa only; whilst of the species, five occur also in the Nile or East Africa, and four in the Congo. We are therefore justified in concluding that this fauna shows no more special affinity to the one watershed than to the other.

List of the Fishes represented in the Collection, with Descriptions of the new Genera and Species ${ }^{1}$.

\section{CROSSOPTERYGII.}

\section{P OLY P T E R I D E.}

\section{Polypterus congicus Blgr.}

Four specimens were brought home of the large Polypterus observed by Mr. Moore on his first visit, and identified by him under the provisional name of $P$. bichir. They prove to be referable to the allied species from the Congo, described by me in 1898 as P. congicus (Ann. \& Mag. N. H. [7] ii. p. 418).

Particulars are appended of the four specimens, from the middle of the lake off Kalambo, at about 5 fathoms, caught in trammel-nets :-

\begin{tabular}{|c|c|c|c|c|}
\hline Total length (in millimetres) ......... & $\begin{array}{c}1 . \\
620\end{array}$ & $\begin{array}{c}2 . \\
580\end{array}$ & $\begin{array}{c}3 . \\
530\end{array}$ & $\begin{array}{c}4 . \\
520\end{array}$ \\
\hline Length of head (in millimetres) $\ldots \ldots \ldots \ldots \ldots \ldots$ & 130 & 110 & 105 & 100 \\
\hline 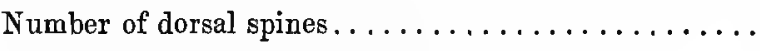 & 13 & 13 & 14 & 13 \\
\hline Number of scales along the side............... & 56 & 55 & 57 & 57 \\
\hline Number of scales round the body $\ldots \ldots \ldots \ldots \ldots$ & 47 & 47 & 47 & 47 \\
\hline Number of scales between occiput and first dorsal spine. & 14 & 14 & 12 & 13 \\
\hline
\end{tabular}

A small azygous shield usually separates the nasals in this species; it is, however, absent in two of the specimens $(3,4)$.

${ }^{1}$ Of which preliminary diagnoses have already appeared in Anu. \& Mag. N. H. (7) vi. 1900, p. 478 , and vii. 1900 , p. 1. 
The dark transverse bands, 6 to 8 in number, characteristic of this species, are very strongly marked in one of the specimens.

The ascertained range of this Polypterus in the Congo is from the region of the cataracts to the Stanley Falls.

\section{'TELEOSTEI.}

\section{CH A R A C I N I D $\mathbb{E}$.}

\section{Alestes macrophthalmus Gthr.}

When this species was first recorded from Lake Tanganyika, it was only known from the Gaboon. It has since been found in Lake Mweru and in the Congo.

3. Alestes macrolepidotus C. \& V.

Kalambo.

4. Citharinus gibbosus Blgr.

Kalambo. 'The largest specimen measures 500 millim.

When I described this fine fish from the Congo, I expressed the opinion that it would probably turn out to be the same as one of which I had seen a coloured sketch made by Mr. Moore on his first expedition.

\section{CYPRINID $A$.}

5. Capoëta tanganice. (Plate XII. fig. 1.)

Bouleng. Ann. \& Mag. N. H. (7) vi. 1900, p. 478.

Depth of body $3 \frac{3}{4}$ to 4 times in total length, length of head 5 times. Snout broad and rounded, as long as or slightly longer than the eye, the diameter of which is $3 \frac{1}{2}$ times in the length of the head and nearly twice in the interocular width; the width of the mouth equals $\frac{2}{3}$ that of the head; a minute barbel, hidden under the lip at the angle of the mouth. Dorsal III 9 ; third ray very strong, ossified, smooth; the fin, which is equally distant from the eye and from the caudal, has the free edge notched, and its greatest depth equals the length of the head. Anal III 5 ; the longest ray measures $\frac{3}{4}$ the length of the head. Pectoral acutely pointed, as iong as the head, not reaching the ventral, which is inserted under the first rays of the dorsal. Caudal forked. Caudal peduncle twice as long as deep. Scales $68-70 \frac{13-14}{14-15}, 9$ or 10 between the lateral line and the root of the ventral. Olive above, each scale darker at the base, silvery white beneath; fins greyish.

Total length 320 millim.

Three specimens from the north end of Lake Tanganyika.

The discovery of a species of this genus in Lake 'Tanganyika is particularly interesting from the fact that only one was known from Africa, viz. the Abyssinian 
C. dilloni C. \& V.; this is distinguished by the absence of barbels and the greater size of the scales (30 to 32 in the lateral line). In the presence of a pair of barbels and the small size of the scales, $C$. tanganicce belongs to the typical section of the genus, inhabiting South-western Asia; but it has the enlarged dorsal ray neither feeble as in C.fundulus Pall. and allied species, nor serrated as in C. trutta Heck.

6. Barbus platyrhinus. (Plate XII. fig. 2.)

Bouleng. Ann. \& Mag. N. H. (7) vi. 1900, p. 479.

Depth of body $3 \frac{1}{4}$ times in total length, length of head 4 times. Snout broad and rounded, twice as long as the diameter of the eye, which is contained $5 \frac{1}{2}$ times in the length of the head and $2 \frac{1}{2}$ times in the interocular width; mouth small, with two pairs of subequal barbels, the length of which equals the diameter of the eye. Dorsal III 8 ; third ray not enlarged, not serrated; the fin, which is equally distant from the eye and from the caudal, has the free edge convex. Anal III 5, tl.e longest ray not quite $\frac{2}{3}$ the length of the head. Pectoral a little shorter than the head, not reaching the ventral, which is inserted below the middle of the dorsal. Caudal forked. Cauclal peduncle $1 \frac{2}{3}$ as long as deep. Scales $40 \frac{5_{\frac{1}{2}-6 \frac{1}{2}}}{5 \frac{1}{2}}, 3 \frac{1}{2}$ between the lateral line and the root of the ventral. Olive-brown above the lateral line, golden yellow beneath.

Total length 390 millim.

A single specimen from south of Usambura.

This species appears to be more nearly related to $B$. capensis, Smith, from which it differs in the much shorter and broader snout.

7. Barbus altianalis. (Plate XIII. fig. 1.)

Bouleng. Ann. \& Mag. N. H. (7) vi. 1900, p. 479.

Depth of boly equal to or slightly greater than the length of the head, which is contained 4 to $4 \frac{1}{2}$ times in the total length. Snout moderately broad, rounded, scarcely projecting beyond the lower jaw, $1 \frac{1}{2}$ to $1 \frac{2}{3}$ times as long as the dinmeter of the eye, which is contained 5 to $5 \frac{1}{2}$ times in the length of the head and twice to twice and one-fourth in the interocular width; mouth small, with two pairs of subequal barbels, the length of which equals or exceeds a little the diameter of the eye. Dorsal III-IV 9; third or fourth ray very strong, ossified, not serrated; the fin, which is equally distant from the occiput and from the caudal, has the free edge notched and its greatest depth is but slightly less than the length of tlie head. Anal III 5; the longest ray measures about $\frac{5}{6}$ the length of the head; the fin, when folded, reaches nearly the root of the caudal. Pectoral a little shorter than the head, not reaching the ventral, the first ray of which corresponds to the origin of the dorsal. Caudal forked. Caudal peduncle nearly twice as long as deep. Scales $34-35 \frac{6 \frac{\pi}{2}}{5 \frac{1}{2}}, 3$ between the lateral line and the root of the ventral. Olive.brown, very dark above.

Total length 450 millim. 
Two specimens from Lake Kiva and one from the source of the Rusisi River.

$B$. altianalis is extremely closely related to $B$. mariquensis Smith. It differs only in the somewhat broader snout, the stronger third dorsal ray, and the somewhat longer caudal peduncle.

8. Barbus serrifer. (Plate XIV fig. 1.)

Bouleng. Ann. \& Mag. N. H. (7) vi. 1900, p. 479.

Depth of body 3 to $3 \frac{1}{2}$ times in total length, length of head 4 to $4 \frac{1}{3}$ times. Snout rounded, not projecting beyond the lower jaw, as long as or a little longer than the diameter of the eye, which is contained 4 to $4 \frac{1}{3}$ times in the length of the head and $1 \frac{1}{3}$ to $1 \frac{1}{2}$ times in the interocular width; mouth small, with two pairs of barbels, the posterior of which are the longer and measure twice the diameter of the eye. Dorsal III 7 ; third ray very strong, ossified, serrated behind; the fin, which is equally distant from the eye and from the caudal, is not notched and the largest ray is a little shorter than the head. Anal III 5, the longest ray $\frac{3}{5}$ the length of the head. Pectoral $\frac{3}{4}$ to $\frac{4}{5}$ the length of the head, reaching, or nearly reaching, the base of the ventral, the last ray of which falls under the first of the dorsal. Caudal forked. Caudal peduncle $1 \frac{1}{2}$ to $1 \frac{2}{3}$ as long as deep. Scales $28-30 \frac{4 \frac{1}{2}-5 \frac{1}{2}}{5 \frac{1}{2}}, 3$ between the lateral line and the root of the ventral. Olive-brown above, silvery white beneath; a greyish stripe along each side of the body above the lateral line; a small blackish spot at the base of the caudal.

Total length 120 millim.

Three specimens from the north end of Lake Tanganyika.

Allied to $B$. Kessleri Stdr. Distinguished by the smaller eye, the longer barbels. the more numerous scales, and the presence of only 7 branched dorsal rays.

9. Barbus tropidolepis. (Plate XIII. fig. 2.)

Bouleng. Ann. Mus. Congo, Zool. i. p. 133, pl. xlix. fig. 2 (1900).

Depth of body 3 times in total length, length of head 4 to $4 \frac{1}{2}$ times. Snout broad and rounded, strongly projecting beyond the mouth, $1 \frac{1}{2}$ to twice as long as the diameter of the eye, which is contained $4 \frac{1}{2}$ to $5 \frac{1}{2}$ times in the length of the head and 2 to $2 \frac{1}{2}$ times in the interocular width ; mouth small, inferior ; a minute barbel almost entirely concealed in the angle of the lips. Dorsal III 9 ; third ray very strong, ossified, not serrated, its length at least $\frac{2}{3}$ that of the head; the fin, which is equally distant from the occiput and the root of the caudal, is notched. Anal II 5 , the longest ray about $\frac{3}{4}$ the length of the head. Pectoral about $\frac{3}{4}$ the length of the head, not reaching the base of the ventral, the first ray of which falls under the origin of the dorsal. Caudal forked. Caudal peduncle $1 \frac{1}{2}$ to $1 \frac{3}{4}$ as long as deep. Scales $44-46 \frac{8 \frac{1}{2}}{8 \frac{1}{2}}, 5$ between the lateral line and the root of the ventral; in breeding specimens, the scales, those at least which are above the lateral line on the caudal portion of the body, bear a median

VOL. XVI.-PART III. No. 2.-October, 1901. 
swelling or obtuse keel, these keels forming together very regular longitudinal lines. Olive above, silvery white beneath.

This handsome fish, which grows to a length of three feet, and the flesh of which is much esteemed, was discovered almost simultaneously at Albertville by Capt. Hecq and at Usambura by Mr. Moore.

10. Barilius mooril. (Plate XIV. figs. 2, 2 a.)

Bouleng. Ann. \& Mag. N. H. (7) vi. 1900, p. 480.

Depth of body equal to length of head, 4 times in total length. Head a little over twice as long as broad, with slightly curved upper profile; snout pointed, not extending beyond the Jower jaw, as long as or a little longer than the diameter of the eye, which is contained 4 to $4 \frac{1}{2}$ times in the length of the head; interorbital width a little greater than the diameter of the eye; mouth extending to below the anterior third or the centre of the eye; no barbels; the naked space between the præopercle and the suborbitals less than half the width of the latter. Gill-rakers very short, almost rudimentary, 8 on lower part of anterior arch. Dorsal III 9, originating at equal distance from the anterior border of the eye and the root of the caudal; its border is not notched, and its depth equals about $\frac{2}{3}$ the length of the head. Anal III 13-14, originating under the middle of the dorsal ; its anterior rays a little longer than those of the dorsal and much longer than the posterior rays, forming a rounded lobe. Pectoral pointed, shorter than the head, not reaching the ventral, which extends to the origin of the anal. Caudal forked. Caudal peduncle twice as long as deep. Scales 56-60 $\frac{10-11}{7}, 3$ between the lateral line and the root of the ventral. Silvery, brownish on the back; more or less distinct dark vertical bars on the side of the body, about 10 in number; dorsal blackish at the end.

Total length 115 millim.

Several specimens from the north end of Lake Tanganyika.

\section{Barilius tanganicle. (Plate XIV. figs. 3,3 a.)}

Bouleng. Ann. \& Mag. N. H. (7) vi. 1900, p. 480.

Depth of body equal to length of head, $4 \frac{1}{4}$ times in total length. Head a little over twice as long as broad, with straight declivous upper profile; snout very pointed, not extending below the lower jaw, once and a half the diameter of the eye, which is contained $5 \frac{1}{3}$ times in the length of the head; interorbital width once and a half the diameter of the eye; mouth extending to below the posterior border of the eye; no barbels; the naked space between the præopercle and the suborbitals about $\frac{1}{3}$ the width of the latter. Gill-rakers short, 10 on lower part of anterior arch. Dorsal III 10, originating at equal distance from the occiput and the root of the caudal, the posterior third of its base above the anal; its anterior rays are longest, measuring a little more than half the length of the head. Anal III 17, strongly notched, with rounded 
anterior lobe, the longest rays of which measure $\frac{2}{3}$ the length of the head, whilst the posterior rays measure barely $\frac{1}{4}$. Pectoral pointed, $\frac{3}{4}$ length of head, not reaching the ventral, which extends to the vent. Candal forked. Caudal peduncle a little over twice as long as deep. Scales $82 \frac{13}{7}, 4$ between the lateral line and the root of the ventral. Silvery, olive on the back; 16 or 17 blackish vertical bars on each side of the body, equally distant from the median dorsal line and from the lateral line.

Total length 260 millim.

A single specimen from the north end of Lake Tanganyika.

$B$. tanganico is nearly related to $B$. (Pelotrophus) microlepis Gthr., from Lake Nyasa. It is distinguished from it by the lesser number of scales between the lateral line and the ventral fin and the greater approximation of the ventral to the anal.

\section{Chrysichthys myriodon.}

\section{S I L U R I D $\mathbb{E}$.}

Bouleng. Ann. Mus. Congo, Zool. i. p. 139, pl. li. (1900).

Depth of body $4 \frac{1}{2}$ times in total length, length of head $3 \frac{1}{3}$ to $3 \frac{1}{2}$ times. Head broad and much depressed, $\frac{1}{6}$ longer than broad, rough on the vertex and occiput; snout broadly rounded, scarcely projecting beyond the lower jaw, $\frac{1}{3}$ length of head, and twice the diameter of the eye, which is contained 6 times in the length of the head and 2 to $2 \frac{1}{2}$ times in the interocular width; the occipital process, which is rough like the occiput, in contact with the interspinous shield; nasal barbel $\frac{3}{4}$ or $\frac{4}{5}$ the diameter of the eye: maxillary barbel a little more than half the length of the head; inner mandibnlar barbel $\frac{1}{3}$ length of head, outer a little less than half. Vomero-pterygoid teeth very fine and closely set, as are also the præmaxillary and mandibular teeth, forming a broad, horseshoe-shaped, uninterrupted band; its width in the middle a little less than that of the præmaxillary band, but increasing at the sides, where it much exceeds the latter. Dorsal I 6 ; spine rugose, not serrated, nearly half the length of the head and $\frac{3}{4}$ or $\frac{4}{5}$ the length of the longest soft rays. Adipose dorsal a little longer than deep, its base $\frac{2}{3}$ that of the rayed dorsal and $\frac{1}{3}$ the distance which separates it from the latter. Anal IV 8-9. Pectoral spine a little longer and stronger than the dorsal, feebly striated, and bearing on its inner edge about 20 strong retrorse serræ. Ventral not reaching the anal. Caudal deeply notched, with obtusely pointed lobes; the longest rays measuring double the length of the median. Caudal peduncle $1 \frac{2}{3}$ to twice as long as deep. Olive-brown above, white beneath.

Total length 470 millim.

This description is taken from three large specimens-one received from Albertville by the Congo Museum, through Capt. Hecq, one from Tembwi, and one from Kinyamkolo, brought home by Mr. Moore. Compared with specimens of C. cranchii of similar size, $C_{v}$ myriodon differs by its smaller and more numerous teeth, the greater posterior width of the vomero-pterygoid band, the larger eye, and the more strongly serrated pectoral spine. It has also a higher number of vertebræ $(20+27)$. 
Young specimens, measuring up to 130 millim., collected at Kibwesi, in deep water, by Mr. Moore, may, I think, be referred to this species. The depth of the body is 5 or 6 times in the total length; head $\frac{1}{4}$ or $\frac{1}{5}$ longer than broad; diameter of the eve $3 \frac{1}{2}$ to $3 \frac{2}{3}$ times in the length of the head, $1 \frac{1}{4}$ to $1 \frac{1}{3}$ in the interocular width; maxillary barbel $\frac{2}{3}$ to $\frac{3}{4}$ the length of the head: vomero-pterygoid teeth forming a narrow subcrescentic band, slightly interrupted mesially. Base of adipose dorsal $\frac{1}{2}$ or $\frac{2}{5}$ its distance from the rayed dorsal; anal IV 8-10; 7 to 9 very large retrorse serræ on the inner side of the pectoral spine. A blackish spot at the end of the dorsal, and another on each lobe of the candal.

\section{Cifrysichthys brachynema. (Plate XV.)}

Bouleng. Anu. \& Mag. N. H. (7) vi. 1900, p. 480.

Depth of body 4 to 5 times in total length, length of head $3 \frac{1}{3}$ to $3 \frac{1}{2}$ times. Head broad and much depressed, $\frac{1}{5}$ or $\frac{1}{6}$ longer than broad, covered with thick smooth skin ; snout much flattened, twice as broad as long, broadly rounded, projecting a little beyond the lower jaw, its length $\frac{1}{3}$ that of the head; diameter of the eye $1 \frac{1}{2}$ to twice in the length of the snout, 5 or 6 times in the length of the head, and 2 or $2 \frac{1}{2}$ in the interocular width; occipital process hidden under the skin, but reaching the interneural shield : nasal barbel as long as or slightly longer than the diameter of the eye in the young, $\frac{2}{3}$ the diameter of the eye in the adult; maxillary barbel $\frac{1}{2}$ or $\frac{1}{3}$ the length of the head; outer mandibular barbel $\frac{1}{2}$ or $\frac{1}{3}$ the length of the head, inner $\frac{1}{4}$ or $\frac{1}{5}$. Vomero-pterygoid teeth forming a broad crescentic or horseshoe-shaped band, uninterrupted or narrowly interrupted mesially; this band as broad as the præmaxillary band in the adult, also widening behind, narrower and more tapering behind in the young. Dorsal I 6 ; spine very feebly serrated in front and behind, covered with a thick skin, its length $\frac{2}{5}$ that of the head and a little shorter than the soft rays. Adipose dorsal $1 \frac{1}{2}$ to twice as long as deep, its base hardly equal to that of the rayed dorsal and $\frac{1}{3}$ or $\frac{1}{2} \mathrm{its}$ distance from the latter. Anal IV 8-9. Pectoral spine thicker and longer than that of the dorsal, armed on its inner side with strong retrorse serræ. Ventral not reaching the anal. Caudal deeply notched, with obtusely pointed lobes, the longest rays twice to twice and a half as long as the middle ones. Caudal peduncle $1 \frac{1}{2}$ to $1 \frac{2}{3}$ as long as deep. Olive above, white beneath.

Total length 400 millim.

Several specimens from Kalambo and Usambura.

This species is also closely allied to $C$. cranchii, but may be distinguished from it by the absence of rugosities on the skull, the shorter head, and the shorter mandibular barbels.

14. Auchenoglanis biscutatus Geoffr.

Kalambo; also far out, in deep water. 


\section{Synodontis granulosus. (Plate XV1.)}

Bouleng. Ann. \& Mag. N. H. (7) vi. 1900, p. 480.

Body feebly compressed, its depth equal to the length of the head and contained 3 to $3 \frac{1}{2}$ times in the total length. Head not or but slightly longer than broad, feebly depressed, covered with granular asperities; frontal fontanelle rather narrow; snout rounded, a little more than half the length of the head; eye directed upwards, its diameter $5 \frac{1}{2}$ to 6 times in the length of the head, $2 \frac{1}{2}$ to $2 \frac{2}{3}$ times in the width of the interocular region, which is slightly convex; no occipital keel. Iips moderately developed; maxillary barbel simple, as long as or a little longer than the head, and not extending beyond the anterior third of the pectoral spine; mandibular barbels inserted on a straight transverse line, the outer $\frac{3}{5}$ or $\frac{2}{3}$ the length of the head and thrice that of the inner, both with very short branches, especially near the base, where they are tubercular. Præmaxillary teeth small and numerous, forming a broad band; anterior mandibular teeth small, feebly curved, hardly $\frac{1}{3}$ the diameter of the eye, and numbering 40 to 42. Gill-cleft not extending inferiorly beyond the base of the pectoral fin. Occipito-nuchal shield rugose, tectiform, a little longer than broad, ending in two rounded points which extend to the level of the base of the first soft dorsal ray. Humeral process covered with granular asperities, keeled, narrow, and sharply pointed, extending nearly as far back as the occipito-nuchal shield. The skin of the whole body, including the adipose fin, covered with small, closely-set, granular papillæ. Dorsal I 7 ; spine rather strong, $1 \frac{1}{2}$ times as long as the base of the fin, striated and armed behind with 10 to 15 retrorse serræ. Adipose dorsal 4 times as long as deep, $2 \frac{1}{2}$ to $3 \frac{1}{2}$ times as long as its distance from the rayed dorsal. Anal III 8. Pectoral spine very strong, as long as that of the dorsal, striated, feebly denticulate on the anterior border, with 15 to 17 strong retrorse serræ on the posterior border. Ventral not reaching anal. Caudal deeply notched. Olive above, yellowish beneath; dorsal, anal, and paired fins black in front, orange behind; caudal black, with a broad orange posterior margin.

Total length 230 millim.

Three specimens from the north end of Lake Tanganyika, in rather deep water.

16. Symodontis Multipunctatus Blgr.

Kalambo.

17. Malopterurus electricus Lacép.

Kalambo.

S E R R A N I D E.

18. Lates MiCRolepis Blgr.

Kinyamkolo, and middle of lake, in deep water.

Mr. Moore has satisficd himself that the ferocious fish, over four feet long, attacking 
the paddles of boats, to which the late E. J. Glave first drew attention ('Century Magazine,' liii. 1897, p. 902), is no other than the adult of the Lates discovered by him, and which was described in the first Report from young specimens.

C I C H L I D \&.

19. Lamprologus lemairir Blgr.

Specimens obtained at Kibwesi and at Msambu show this fish to grow to a length of 230 millim. It is by far the largest species of the genus.

20. LAMPRologus FurCiFer Blgr.

Msambu.

21. Paratilapia vittata. (Plate XVIII. fig. 1.)

Bouleng. Ann. \& Mag. N. H. (7) vii. 1901, p. 1.

Depth of body $3 \frac{1}{3}$ to $3 \frac{1}{2}$ times in total length, length of head $2 \frac{2}{3}$ to 3 times. Profile of snout convex; lower jaw projecting beyond the upper; diameter of eye $1 \frac{1}{2}$ to $1 \frac{2}{3}$ times in length of snout, 4 to $4 \frac{3}{4}$ times in length of head, and equal to interocular width ; maxillary extending to below anterior border of eye ; teeth in 3 or 4 rows, the outer much larger than the others; 3 or 4 series of scales on the cheek; large scales on the opercle. Gill-rakers short, 10 to 12 on lower part of anterior arch. Dorsal XV-XVI 8-9; spines subequal from the seventh or eighth, which measures about $\frac{1}{3}$ length of head and $\frac{2}{3}$ longest soft rays. Pectoral pointed, about $\frac{2}{3}$ length of head. Ventral reaching vent or origin of anal. Anal III 8-9; third spine longest, as long as middle dorsal spines. Caudal feebly emarginate. Caudal peduncle $1 \frac{1}{2}$ times as long as deep. Scales with finely denticulate border, 33-35 $\frac{4}{11-12}$; lat. 1. $\frac{20-21}{10-13^{\circ}}$ Olive above, whitish beneath; a blackish stripe on each side above the upper lateral line, and a second from the opercle to the root of the caudal fin, passing over the lower lateral line; dorsal, anal, and caudal fins greyish or blackish, ventrals black in the males.

Total length 120 millim.

Several specimens from Lake Kivu.

22. Paratilapia aurita. (Plate XIX. fig. 2.)

Bouleng. l. c. p. 2.

Depth of body 3 to $3 \frac{1}{4}$ times in total length, length of head $3 \frac{1}{4}$ to $3 \frac{1}{2}$ times. Snout short, as long as or a little shorter than the eye, with slightly curved upper profile; lower jaw not projecting beyond the upper ; diameter of eye $3 \frac{1}{4}$ to $3 \frac{3}{4}$ times in length of head, equal to or greater than interocular width; maxillary extending to below anterior fourth or third of eye; teeth in 2 or 3 rows, the outer much larger than the others ; 4 or 5 series of scales on the cheek; large scales on the opercle. Gill-rakers 
short, 10 or 11 on lower part of anterior arch. Dorsal XV-XVII 9-10; spines increasing in length to the last, which is a little less than half length of head; the longest soft rays produced into filaments, and only a little shorter than head. Pectoral pointed, as long as head. Ventral produced in a filament, and extending to vent or beyond. Anal III 8; third spine stronger and shorter than the last dorsal spine. Caudal feebly emarginate. Caudal peduncle $1 \frac{1}{2}$ times as long as deep. Scales with finely denticulate border, $35-36 \frac{3-4}{9-10}$; lat. 1. $\frac{22-25}{14-18}$. Brownish, with or without oblique cross-bars of mother-of-pearl or silvery white, sometimes with ill-defined dark bars across the back; a very distinct, blue-black, opercular spot; dorsal and anal grey or blackish, often striated or spotted with white; the membrane between the dorsal spines edged with black; anal sometimes blackish.

Total length 130 millim.

Numerous specimens from Msambu.

23. Paratilapia bloyeti Sauvage.

Lake Kivu. I have compared the specimens brought home by Mr. Moore with one of the type specimens from Kandoa, Usagara, German East Africa.

24. Paratilapia calliura. (Plate XIX. fig. 3.)

Bouleng. Ann. \& Mag. N. H. (7) vii. 1901, p. 2.

Depth of body 4 to $4 \frac{1}{2}$ times in total length, length of head 3 to $3 \frac{1}{3}$ times. Snout pointed, with straight upper profile, as long as or a little shorter than the eye, the diameter of which is double the interocular width and is contained 3 to $3 \frac{1}{3}$ times in length of bead; lower jaw projecting beyond the upper; maxillary extending to below anterior fourth of eye; teeth small, in two rows; 2 or 3 series of scales on the cheek; large scales on the opercle. Gill-rakers moderately long, 15 on lower part of anterior arch. Dorsal XVI-XVII 10 ; spines increasing in length to the last, which measures $\frac{2}{5}$ or $\frac{1}{2}$ length of head; longest soft rays $\frac{2}{3}$ or $\frac{3}{4}$ length of head. Pectoral pointed, a little shorter than head. Ventral reaching vent. Anal III 7-8; third spine longest, a little shorter than last dorsal spine. Caudal feebly emarginate. Caudal peduncle $1 \frac{1}{2}$ times as long as deep. Scales with finely denticulate border,

37-40 $\frac{2-3}{9-10}$; lat. $1 . \frac{25-29}{13-17}$. Pale brownish above, silvery beneath; a blackish opercular spot; dorsal and anal edged with black; 4 or 5 black bars across the caudal; young with black bars across the dorsal.

Total length 110 millim.

Several specimens from Kalambo.

25. Paratilapia stenosoma. (Plate XVII. fig. 1.)

Bouleng. Ann. \& Mag. N. H. (7) vii. 1901, p. 2.

Body very strongly compressed, its depth equal to the length of the head and 
contained $2 \frac{3}{4}$ to 3 times in total length. Profile of snout descending in a straight or slightly convex line; lower jaw projecting beyond the upper; diameter of eye nearly equal to length of snout or interocular width, $3 \frac{1}{3}$ to $3 \frac{1}{2}$ times in length of head; maxillary not extending to below anterior border of eye; teeth small, in 2 or 3 rows, the outer very slightly larger than the others; 2 series of scales on the cheek; very thin scales on the opercle. Gill-rakers rather long and closely set, 19 to 23 on lower part of anterior arch. Dorsal XV 13 ; last spine longest, $\frac{2}{5}$ length of head; soft rays longer, sometimes produced into filaments. Pectoral pointed, a little shorter than head. Ventral reaching vent. Anal III 12-13; third spine longest, a little stronger but shorter than last dorsal spine. Caudal deeply emarginate. Caudal peduncle nearly twice as long as deep. Scales without marginal denticulation, $60-68 \frac{6}{16}$; lat. 1. $\frac{54-58}{31-34}$. Brownish above, silvery beneath, with or without blackish spots and longitudinal bands ; dorsal blackish at the end.

Total length 220 millim.

Several specimens from Maswa and from the south end of Lake Tanganyika.

26. Paratilapia leptosoma Blgr.

Msambu.

27. Paratilapia nigripinnis. (Plate XIX. fig. 1.)

Bonleng. Ann. \& Mag. N. H. (7) vii. 1901, p. 3.

Depth of body 4 times in total length, length of head 3 to $3 \frac{1}{4}$ times. Snout with straight upper profile, as long as diameter of eye, which equals interocular width and is contained $3 \frac{1}{3}$ times in length of head; mouth extremely protractile; maxillary extending to below anterior border of eye; teeth very small, in 3 rows; 2 or 3 series of scales on the cheek; opercle covered with scales. Gill-rakers long and thin, closely set, 20 on lower part of anterior arch. Dorsal XV-XVII 11 ; spines increasing in length to the last, which measures $\frac{2}{5}$ length of head; soft rays longer. Pectoral pointed, as long as head. Ventral reaching origin of anal or beyond. Anal III 8-9; third spine as long as the last dorsal. Caudal deeply emarginate, the lobes produced into filaments. Caudal peduncle twice as long as deep. Scales with denticulate border, $39-40 \frac{3}{11}$; lat. l. $\frac{29-30}{13-16}$. Dark brown, lighter beneath; fins blackish, the caudal edged with white above and beneath.

Total length 80 millim.

Several specimens from Msambu.

This species is very closely allied to the preceding, but is distinguished by the number of rays in the dorsal and anal fin (D. XV-XVII 11, A. III 8-9, instead of D. XII-XIV 14-1.6, A. III 10-12). 


\section{Bathybates ferox Blgr.}

Several specimens from the South and West Coasts, from Kalambo, and from Usambura. I have also examined specimens from Moliro and Albertville. The species is thus seen to be widely dispersed in the lake, and not confined to great depths.

\section{Bathybates fasciatus. (Plate XVII. fig. 2.)}

Bouleng. Ann. \& Mag. N. H. (7) vii. 1901, p. 3.

Depth of body $4 \frac{1}{3}$ times in total length, length of head $3 \frac{1}{2}$ times. Shape of head similar to that of the preceding species, but eye smaller, its diameter about twice in length of snout, 5 times in length of head, and $1 \frac{1}{2}$ in interocular width ; 8 series of small scales on the cheek; larger scales on the opercle. 18 gill-rakers on lower part of anterior arch. Dorsal XVII 16 ; spines subequal from the fifth, which measures $\frac{1}{4}$ length of head; longest soft rays $\frac{1}{3}$ length of head. Pectoral pointed, $\frac{2}{3}$ length of head. Ventral not half as long as the distance between its base and the vent. Anal III 18 ; spines very weak. Caudal forked. Caudal peduncle twice and a half as long as deep. Scales very small, 140 in a longitudinal series above the upper lateral line, $\frac{11}{25}$ in a transverse series; lat. $1 . \frac{75}{45}$. Brownish above, white beneath; a series of large, rounded, blackish spots on each side of the back above the lateral line, alternating with a series of vertical blackish bars on each side of the body; on the tail, from the middle of the soft dorsal, the spots unite into a band which extends to the caudal, and the vertical bars likewise fuse to form a lateral band; a blackish spot on the opercle, another at the base of the ventral; two black bands on the dorsal, a basal and a marginal.

Total length 340 millim.

A single specimen from the West Coast, at Tembwi.

This second species of the remarkable genus Bathybates differs from its congener in the smaller eye, the more numerous gill-rakers, and the smaller scales.

\section{Pelmatochromis polylepis.}

Bouleng. Anu. Mus. Congo, Zool. i. p. 143, pl. lii. fig. 1 (1900).

Depth of body $2 \frac{1}{2}$ to $2 \frac{2}{3}$ times in total length, length of head 3 to $3 \frac{1}{3}$ times. Snout with straight upper profile, $1 \frac{1}{3}$ times diameter of eye, very deep, its length not exceeding the width of the præorbital region; diameter of eye $3 \frac{1}{2}$ to $3 \frac{2}{3}$ times in length of head, equal to or a little greater than interocular width; maxillary extending nearly to below anterior border of eye; teeth very small, in 4 or 5 irregular rows in both jaws, the outer somewhat larger; 4 or 5 series of scales on the cheek; larger scales on the opercle. Gill-rakers short, lamellar, denticulate, 14 or 15 on lower part of anterior arch. Dorsal XV-XVI 14-15; spines subequal from the sixth, which measures $\frac{2}{5}$ or vol. XVI._PART III. No. 3.-October, 1901. 
a little more than $\frac{1}{3}$ length of head. Pectoral pointed, falciform, at least as long as head. Ventral reaching vent, the outer ray produced into a filament. Anal III 8; third spine much stronger than dorsal spines, nearly $\frac{1}{2}$ length of head. Caudal rather deeply emarginate. Caudal peduncle a little longer than deep. Scales with denticulate border, $55-58 \frac{6-7}{18}$; lat. $1 . \frac{25-31}{47-48}$, the upper extending to below the last spines or the first soft rays of the dorsal, the lower originating a little behind the shoulder and extending to the caudal fin. Body golden, olive on the back; purplish streaks along the dorsal and caudal fins, sometimes forming a wide-meshed network.

Total length 300 millim.

This species was discovered almost simultaneously by Mr. Moore at Kinyamkolo and Kibwesi, and by Capt. Hecq, of the Congo Free State, at Albertville.

The genus Pelmatochromis had not yet been recorded from Lake Tanganyika. $P$. polylepis is very closely allied to $P$. lateralis Blgr., from the Congo; it differs in its much smaller scales.

\section{Ectodus rongianalis Blgr. (Plate XIX. fig. 4.)}

Several specimens from the north end of Lake 'Tanganyika, near Usambura.

The females, measuring 95 millim., contain ripe ova, the diameter of which is 2 millim. In the adult male ( 115 millim.) the upper surface of the snout, the chin, the middle of the throat, the dorsal and anal fins, and the extremity of the ventrals are black; a few large, black, white-edged ocelli on the spinous dorsal, along which runs a white line, which is also present on the soft dorsal and on the anal; oblique white lines on the soft dorsal; large, round, white spots on the ventrals ${ }^{1}$; two crescentic bands on the caudal, the first grey, the second, marginal, blackish.

The specimens brought home by Mr. Moore have enabled me to make an examination of the skeleton, which differs very considerably from that of Paratilapia. Three very low crests, supra-occipital and parietal, extend forwards to between the orbits. The precaudal vertebræ are much fewer than the caudals, 14 of the former as against 24 of the latter, a character, quite exceptional anong the Cichlidoe, shared by the genera Xenotilapia and Trematocara; the ribs are inserted on the parapophyses, the last pair of which form a hæmal arch.

32. Xenotilapia ornatipinnis. (Plate XVIII. fig. 2.)

Bouleng. Ann. \& Mag. N. H. (7) vii. 1901, p. 3.

Depth of body nearly equal to length of head, $3 \frac{1}{3}$ to $3 \frac{1}{2}$ times in total length. Head quite similar to that of $X$. sima. 15 to 17 gill-rakers on lower part of anterior arch. Dorsal XIII-XV 12-13; spines subequal from the 5 th or 6 th, $\frac{2}{5}$ length of head.

\footnotetext{
In this genus the inner rays of the ventral are the longest.
} 
Pectoral pointed, as long as or a little longer than the head. Ventral not reaching anal ${ }^{1}$. Anal III 7-8: third spine $\frac{2}{5}$ length of head. Caudal deeply notched, crescentic. Caudal peduncle $1 \frac{2}{3}$ times as long as deep. Scales with denticulate border, 34-37 $\frac{3}{10}$; lat. 1. $\frac{\frac{28-32}{13-18}}{4-12}$ Pale brownish; a more or less distinct silvery lateral band; spinous dorsal black-edged; large blackish spots or oblique bars on the dorsal; upper lobe of caudal edged with blackish; a chevron-shaped blackish band lower down on the caudal, disposed asymmetrically.

Total length 110 millim.

Several specimens from Kibwesi.

This species is easily distinguished from $X$. sim $\alpha$ by the shorter body, the fewer anal rays, and the lower number of scales in a longitudinal series.

The skeleton of Xenotilapia is very similar to that of Ectodus. There are likewise three low crests on the back of the skull, the vertebræ number $13+22$ in $X$. sima, $14+20$ in $X$. ornatipinnis, and the ribs are remote from the centres.

\section{Trematocara marginatum Blgr.}

Usambura market.

34. Trematocara unimaculatum. (Plate XVIII. fig. 3.)

Bouleng. Ann. \& Mag. N. H. (7) vii. 1901, p. 3.

Depth of body 3 to $3 \frac{1}{2}$ times in total length, length of head $2 \frac{2}{3}$ to $2 \frac{3}{4}$ times. Snout with curved upper profile, as long as or a little shorter than the eye, the diameter of which is nearly double interorbital width and contained 3 to $3 \frac{1}{4}$ times in length of bead; mouth extending to below anterior border of eye; cheek naked; a few deciduous scales on opercle; nasal, frontal, præorbital, suborbital, præopercular, and mandibular bones cavernous, with large cavities covered with thin skin and separated by narrow septa. Gill-rakers short, 17 on lower part of anterior arch. Dorsal X-XII 9-11; spines increasing in length to the 6 th or 7 th, which measures $\frac{1}{2}$ length of head; soft rays scarcely longer. Pectoral very pointed, as long as or a little longer than the head. Ventral reaching origin of anal. Anal III 7-8; third spine nearly as long as dorsals. Caudal deeply notched, crescentic. Caudal peduncle nearly twice as long as deep. Scales $30-32 \frac{3}{7}$; lat. 1. 5-14. Silvery, brownish above; a large, rounded, black spot on posterior third of spinous part of dorsal, rarely followed by a second.

Total length 120 millim.

Several specimens from the Usambura market.

${ }^{1}$ As in Eetodus the inner rays of the ventral are the longest. 
Closely allied to the preceding species. Differing in the longer dorsal spines, fewer anal rays, and in the presence of a black spot on the dorsal.

I have been able to examine the skeleton of this species. The occipital crest is strong and extends to between the orbits; a more feeble parietal crest. The median pharyngeal teeth have rounded spheroidal crowns. 12 præcaudal and 19 caudal vertebræ; the last præcaudal vertebra bears a hæmal arch. It is not without interest to point out the parallelism that can be drawn in comparing Trematocara (with its excessively developed cephalic cavities) with the perch-like Cichla on the one hand and Acerina and Perca, among Percida, on the other :-

$$
\begin{array}{ll|l}
\text { Trematocara : Vert. } 12+19=31 . & \text { Acerina }: \text { Vert. } 15+19=34 . \\
\text { Cichla }: & \text { Vert. } 18-19+17=35-36 . & \text { Perca }: \text { Vert. } 21-22+19-21=41-42 .
\end{array}
$$

The two genera in each family standing very nearly in the same relation to each other both as regards the skull and the vertebral column.

35. Telmatochromis temporalis Blgr.

Kibwesi.

\section{GePHYROCHROMIS.}

Bouleng. Ann. \& Mag. N. H. (7) vii. 1901, p. 4.

A band of very small tricuspid teeth in each jaw, with an outer series of larger conical teeth bent inwards; lateral teeth conical. Maxillary exposed. Body moderately elongate; scales cycloid; two lateral lines. Dorsal with 17 spines, anal with 3.

Differs from Paratilapia as Telmatochromis differs from Lamprologus.

36. Gephyrochromis mooril. (Plate XX. figs. 1, 1 a.)

Bouleng. $l . c$.

Depth of body equal to length of head, 3 times in total length. Snout with slightly convex upper profile, as long as the diameter of the eye, which is contained $3 \frac{1}{3}$ times in length of head and equals interocular width; maxillary extending to between nostril and eye; 56 conical teeth, with brown points, in the upper jaw ; 3 series of scales on the cheek; larger scales on the opercle. Gill-rakers short, 13 on lower part of anterior arch. Dorsal XVII 8; spines increasing in length to the last, which measures $\frac{2}{5}$ length of head and $\frac{2}{5}$ longest soft rays. Pectoral nearly as long as head. Ventral produced into a long filament extending beyond origin of anal. Anal III 7 ; third spine longest, a little shorter than last dorsal spine. Caudal rounded. Caudal peduncle as long as deep. Scales $30 \frac{3}{11}$; lat. l. $\frac{22}{13}$. Uniform pale brown.

'lotal length 120 millim.

A single specimen from the north end of Lake Tanganyika.

37. Simochromis diagramma Gthr.

Msambu. 
38. Tilapia nilotica L.

This Nile species, which is also found in Syria, in the Senegal, Gambia, and Niger, has been found in Lake Kivu.

39. 'Tilapia burtoni Gthr.

Discovered at Ujiji by Mr. Coode Hore, this species has since been found at Albertville by Capt. Hecq. Mr. Moore obtained specimens in Lake Kivu.

40. Tilapia dardenni Blgr.

Kibwesi and Kalambo. Grows to a length of 230 millim.

41. Tilapia labiata Blgr.

Kibwesi.

42. Tilapia Pleurotania. (Plate XVIII. fig. 4.)

Bouleng. Ann. \& Mag. N. H. (7) vii. 1901, p. 4.

Depth of body $2 \frac{1}{2}$ to 3 times in total length, length of head 3 to $3 \frac{1}{2}$ times. Snout with the profile descending in a straight line, as long as the diameter of the eye, which is contained $3 \frac{1}{3}$ to $3 \frac{1}{2}$ times in length of head, and exceeds a little interocular width; mouth small, its width half, or a little more than half, that of the head, extending to below nostril or between nostril and eye; teeth very small, in 3 series, outer bicuspid; 3 or 4 series of scales on the cheek. Gill-rakers short, 10 to 12 on lower part of anterior arch. Dorsal XV-XVIII 11-12; last spine longest, a little less than half length of head; longest soft rays $\frac{2}{3}$ length of head. Pectoral pointed, a little shorter than the head, not quite reaching origin of anal. Anal III 8-10; third spine a little shorter than last dorsal spine. Caudal deeply notched, crescentic. Caudal peduncle $1 \frac{1}{2}$ as long as deep. Scales very thin, without denticulation, 32-35 $\frac{4}{31-12}$; lat. 1. $\frac{22-24}{10-15}$. Pale brown above, white beneath; a blackish lateral stripe, from the opercle to the caudal ; fins greyish ; small, round, white spots on soft dorsal and caudal.

Total length 110 millim.

Several specimens from the north end of Lake Tanganyika and from the mouth of the Rusisi River.

43. Tilapia trematocephala. (Plate XIX. fig. 6.)

Bouleng. Ann. \& Mag. N. H. (7) vii. 1901, p. 4.

Depth of body equal to length of head, $3 \frac{1}{4}$ times in total length. Snout with slightly convex upper profile, a little shorter than diameter of eye, which is contained 3 times in length of head and exceeds interocular width; mouth small, its width half that of head, extending to between nostril and eye; teeth very small, in 2 rows, outer bicuspid; 3 series of scales on the cheek; large scales on the opercle; orifices of sensory canals 
on head remarkably large. Gill-rakers rather short, 13 on lower part of anterior arch. Dorsal XVI 11; last spine longest, half length of head; longest soft rays produced into filaments, half length of head. Pectoral pointed, $\frac{3}{4}$ length of head, not reaching origin of anal. Ventral produced into a filament, extending beyond origin of anal. Anal III 9; third spine as long as and stronger than last dorsal spine; some of the soft rays produced into filaments, as in the dorsal. Caudal deeply emarginate. Caudal peduncle $1 \frac{1}{2}$ as long as deep. Scales very thin, without denticulation, $40 \frac{3}{10}$; lat. $1 . \frac{28}{9}$. Brownish ; dorsal and caudal greyish; ventrals and anal black, latter edged with white.

Total length 90 millim.

A single specimen from the north end of Lake Tanganyika.

44. Tilapia boops. (Plate XIX. fig. 5.)

Bouleng. Ann. \& Mag. N. H. (7) vii. 1901, p. 5.

Depth of body equal to length of head, $3 \frac{1}{4}$ to $3 \frac{1}{3}$ times in total length. Snout with strongly convex upper profile, shorter than diameter of eye, which is $2 \frac{1}{2}$ times in length of head, and exceeds a little interocular width; mouth $\frac{2}{3}$ width of head, subinferior, not extending quite to below anterior border of eye; teeth very small, tricuspid, in 3 rows; 2 or 3 series of scales on the cheek; large scales on the opercle. Gill-rakers short, 13 on lower part of anterior arch. Dorsal XII-XIII 14 ; spines slender, equal from the 7 th, which measures nearly $\frac{1}{3}$ length of head; soft rays scarcely longer. Pectoral pointed, as long as head, reaching origin of anal. Ventral produced into a filament, extending beyond origin of anal. Anal III 8-9; third spine as long as and stronger than longest dorsal spines. Caudal deeply emarginate, crescentic. Caudal peduncle nearly twice as long as deep. Scales thin, without denticulation, $39-40 \frac{5}{14-15}$; lat. 1. $\frac{34-35}{15-19}$. Brown above, white beneath; a blackish opercular spot.

Total length 90 millim.

Two specimens from Msambu.

\section{Tilapia microlepis Blgr.}

Kalambo.

This species grows to a length of 440 millim. Such large specimens lose the secondary cusp of the teeth, and might therefore be referred to the genus Paratilapia.

\section{Petrochromis tanganicas.}

Chromis tanganica Günth. Proc. Zool. Soc. 1893, p. 630, fig.

Kalambo.

This species grows to a length of 300 millim. Adult specimens agree entirely in their dentition with Petrochromis polyodon Blgr. 
AsProtilapia.

Bouleng. Ann. \& Mag. N. H. (7) vii. 1901, p. 5.

Teeth small, tricuspid, closely set, in two series in both jaws. Mouth inferior, transverse; greater part of maxillary bone concealed under the præorbital. Body elongate, much attenuate in the caudal region. Scales ctenoid; two lateral lines. Dorsal with 14 spines, anal with 3 .

Allied to Tilapia. By the form of the body, the type of this genus recalls Aspro among the Percida.

47. Asprotilapia leptura. (Plate XX. figs. $2,2 a, 2 b$.)

Bouleng. $l . c$.

Body rather feebly compressed, its depth 5 times in total length; length of head 4 times in total length. Snout subconical, strongly projecting beyond the mouth, its length $\frac{1}{3}$ that of the head; eye very large, its diameter equal to length of snout and nearly twice interorbital width, $2 \frac{3}{5}$ times in length of hearl; width of mouth $\frac{3}{5}$ that of head; 36 teeth in the outer row of the upper jaw; 3 series of small scales on the cheek; larger scales on the opercle. Gill-rakers very short, tubercle-like, 15 on lower part of anterior arch. Dorsal XIV 12 ; spines slender and subequal, $\frac{2}{5}$ length of head ; soft rays a little longer. Pectoral pointed, a little shorter than head. Ventral reaching vent. Anal III 8; third spine nearly as long as dorsals. Caudal deeply emarginate, crescentic. Caudal peduncle 3 times as long as deep. Scales strongly denticulate, $38 \frac{2}{11}$; lat. l. $\frac{27}{20}$. Brown, darker on the snout and vertex; a blackish opercular spot; fins greyish.

Total length 95 millim.

A single specimen from Msambu.

48. Xenochromis HeCQUi Blgr.

Three specimens from Usambura. Grows to a length of 270 millim. D. XVI-XVII 10-11; A. III 9-10; Sq. $64-67 \frac{6}{20}$; lat. l. $\frac{53-60}{35-43}$.

\section{ASTACEM BELID}

49. Mastacembelus frenatus. (Plate XX. fig. 3.)

Bouleng. Ann. \& Mag. N. H. (7) vii. 1901, p. 5.

Depth of body 13 times in total length, length of head $8 \frac{2}{3}$ times. Vent equally distant from end of snout and from caudal fin, separated from head by a space equal to $3 \frac{2}{3}$ times length of latter. Snout 3 times length of eye, produced into a trifid appendage, the length of which exceeds a little diameter of eye; buccal cleft extending to below anterior border of eye; no præopercular spines. Dorsal and anal confluent 
with caudal, which is short and rounded; dorsal XVIII 85 ; anal II 90 ; first anal spine very short, second $\frac{1}{4}$ length of head; distance between first dorsal spine and head $1 \frac{2}{3}$ times length of latter. Pectoral $\frac{2}{7}$ length of head. Scales extremely small, 22 between origin of dorsal and lateral line. Yellowish brown above, marbled with darker, yellowish beneath; a dark brown streak on each side of the head, passing through the eye; two brown bars across the caudal.

Total length 250 millim.

A single specimen, a female full of ova, from the north end of Lake Tanganyika.

50. Mastacembelus temiatus. (Plate XX. fig. 4.)

Bouleng. Ann. \& Mag. N. H. (7) vii. 1901, p. 6.

Depth of body 13 times in total length, length of head $6 \frac{1}{2}$ times. Vent equally distant from head and from caudal fin, separated from head by a space equal to 3 times length of latter. Snout twice as long as eye, ending in a trifid appendage as long as latter; buccal cleft extending to below anterior border of eye; no præopercular spines. Dorsal and anal fins confluent with caudal, which is short and rounded; dorsal XXXIII 85; anal II 85 ; first anal spine extremely short, second as long as last dorsal. Pectoral $\frac{1}{5}$ length of head. Scales extremely small, 25 between origin of dorsal and lateral line. Yellowish; a brown lateral band, from the end of the snout, through the eye, to the caudal region, where it widens, its borders become sinuous, and it bears some yellow spots.

Total length 105 millim.

A single specimen from the north end of Lake Tanganyika. 
PLATE XII.

VOL. XVI.-PART III. No. 4.-October, 1901. 


\section{PLATE XII.}

Fig. 1. Capoëta tanganicce, p. 143. Reduced $\frac{3}{4}$. Fig. 2. Barbus platyrhinus, p. 144 . Reduced $\frac{3}{5}$. 

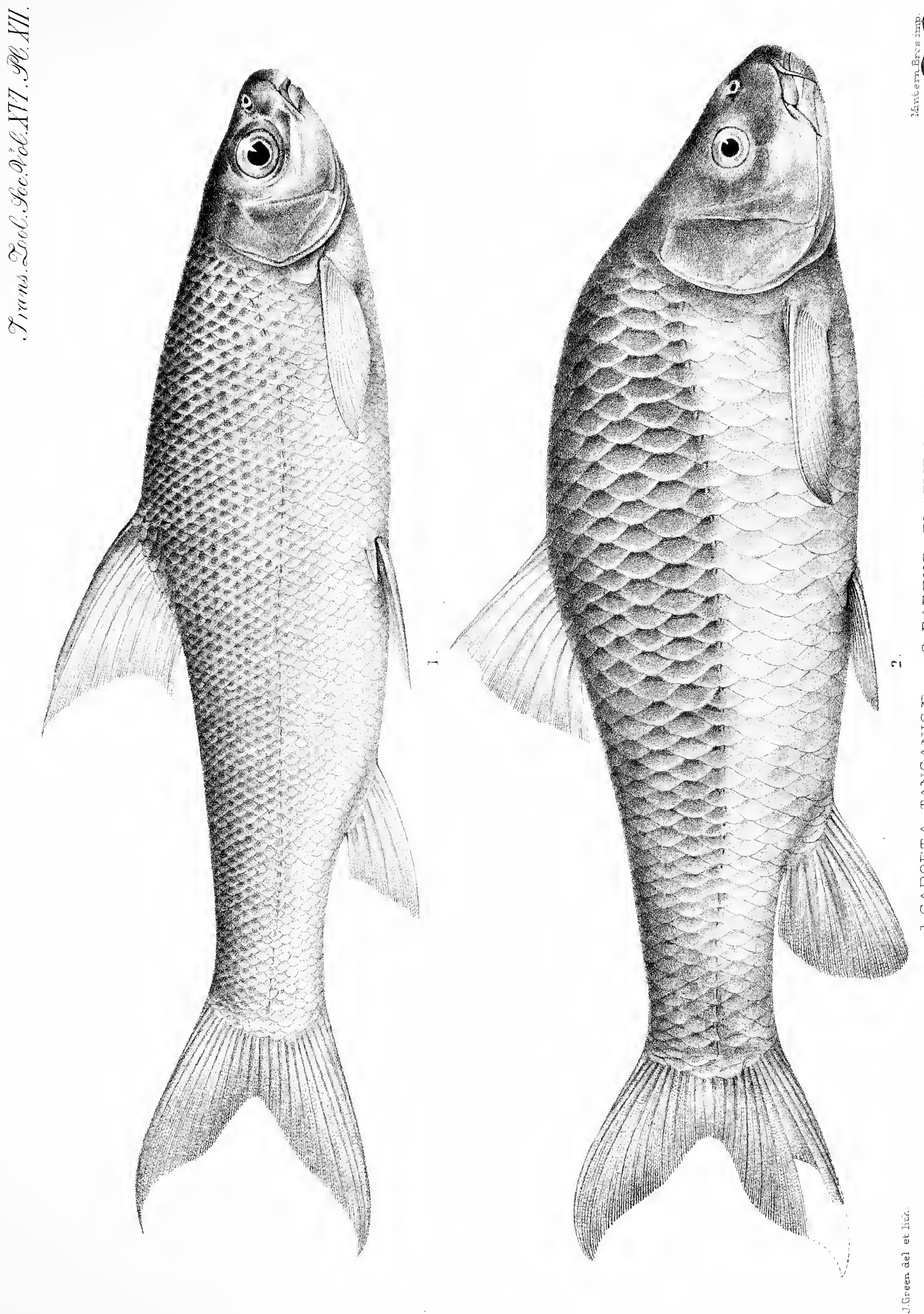

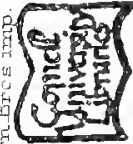

U

I

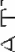

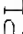

0

吕

1

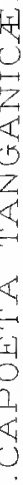



PLATE XIII.

2 в 2 


\section{PLATE XIII.}

Fig. 1. Barbus altianalis, p. 144. Reduced $\frac{7}{11}$.

Fig. 2. " tropidolepis, p. 145. Reduced $\frac{3}{4}$. 

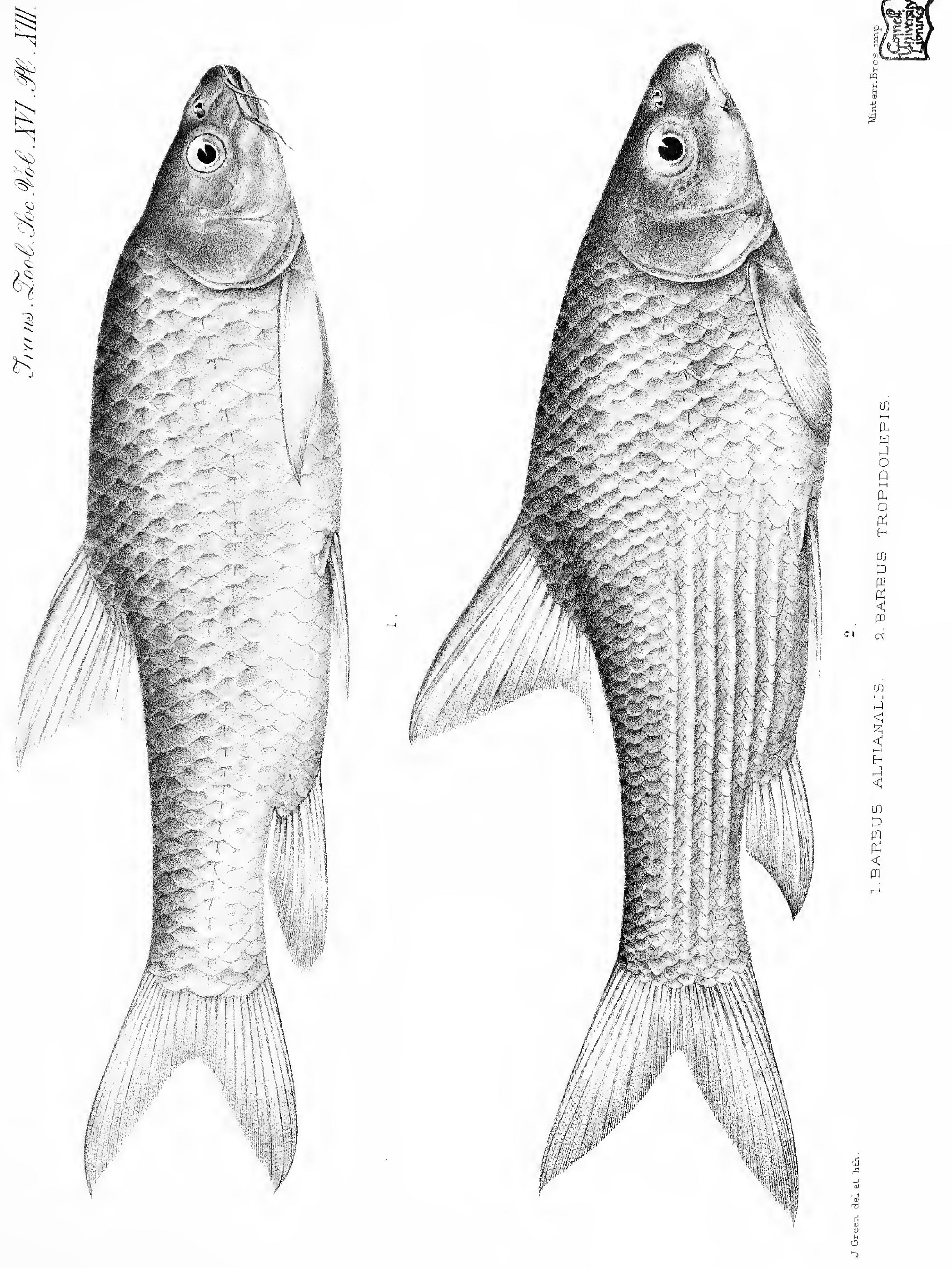

PLATE XIV. 


\section{PLATE XIV.}

Fig. 1. Barbus serrifer, p. 140. Reduced $\frac{6}{7}$.

Fig. 2. Barilius moorii, p. 146 . Reduced $\frac{9}{10}$.

Fig. $2 a$. " , $\quad$ Upper view of head. $\times 2$.

Fig. 3. " tanganico, p. 146. Reduced $\frac{7}{9}$.

Fig. $3 a$. , , " $\quad$ Upper view of head. Nat. size. 

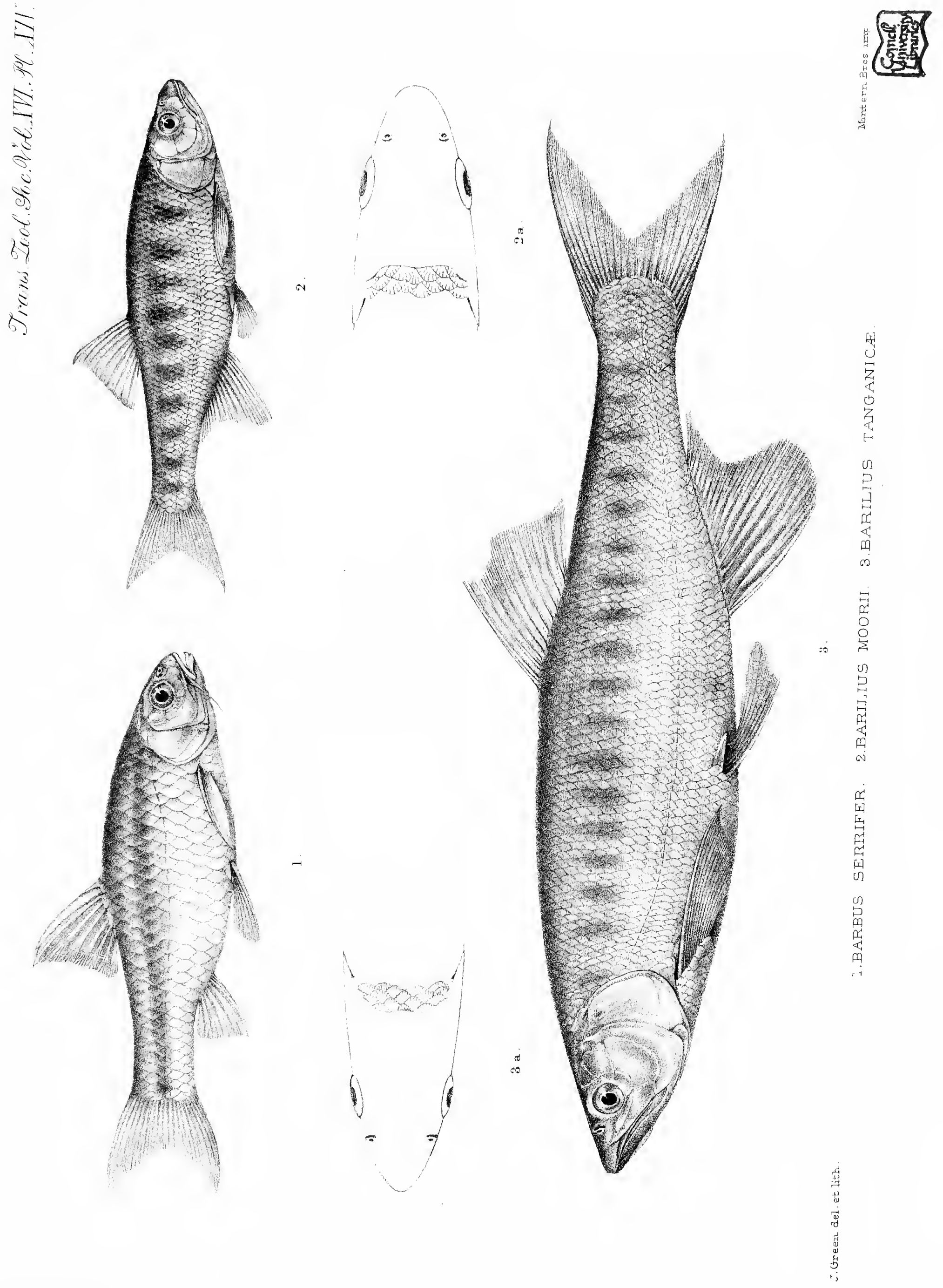



\section{PLATE XV.}




\section{PLATE XV.}

Chrysichthys brachynema, p. 148, with upper view of head, reduced $\frac{5}{9}$; and dentition of upper jaw and palate, nat. size. 


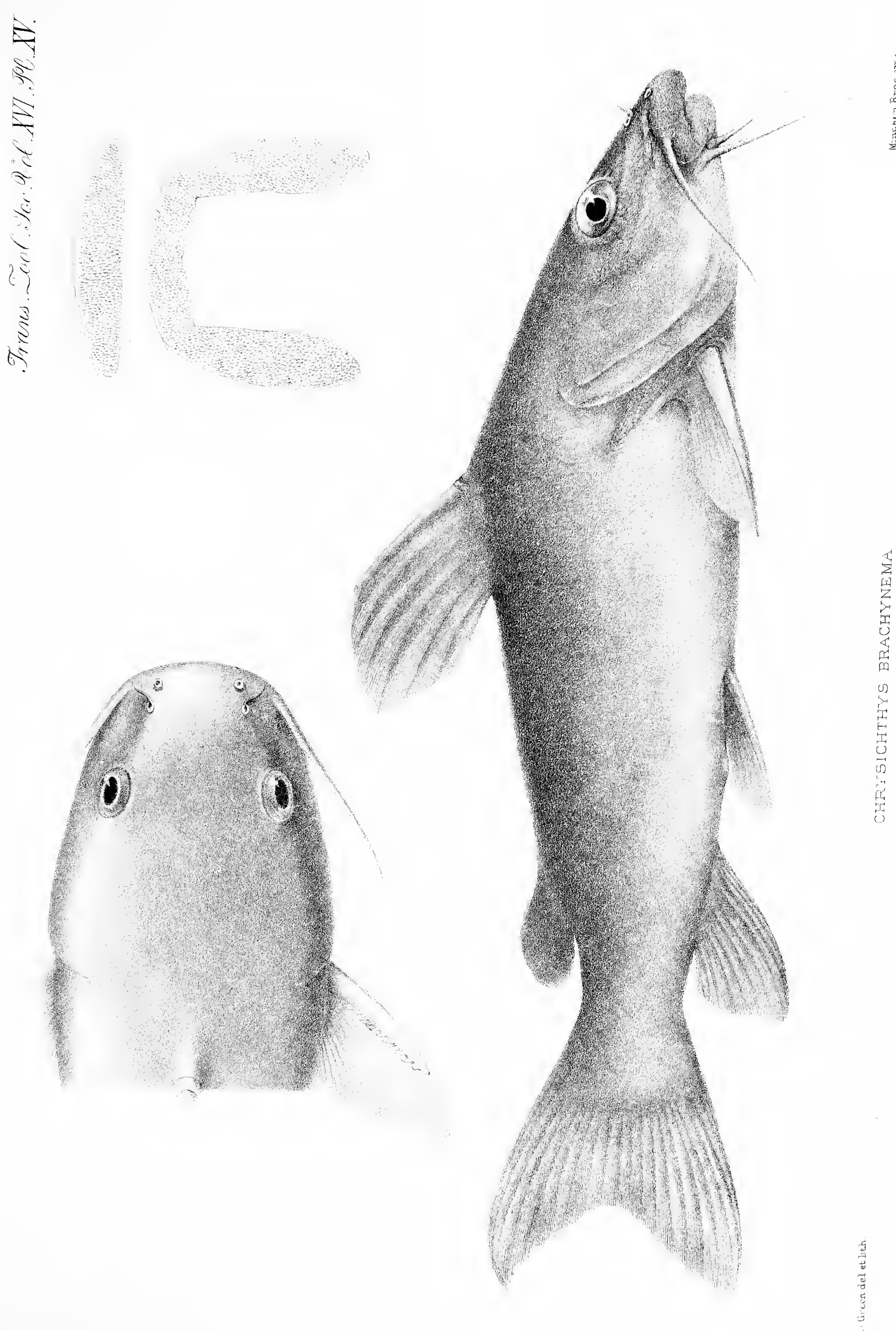

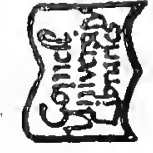

焉 

PLATE XVI.

VOL. XVI.-PART III. No. 5.-October, 1901. 
FISHES FROM LAKES TANGANYIKA AND KIVU.

\section{PLATE XVI.}

Synodontis granulosus, p. 149, with upper and lower views of head. 


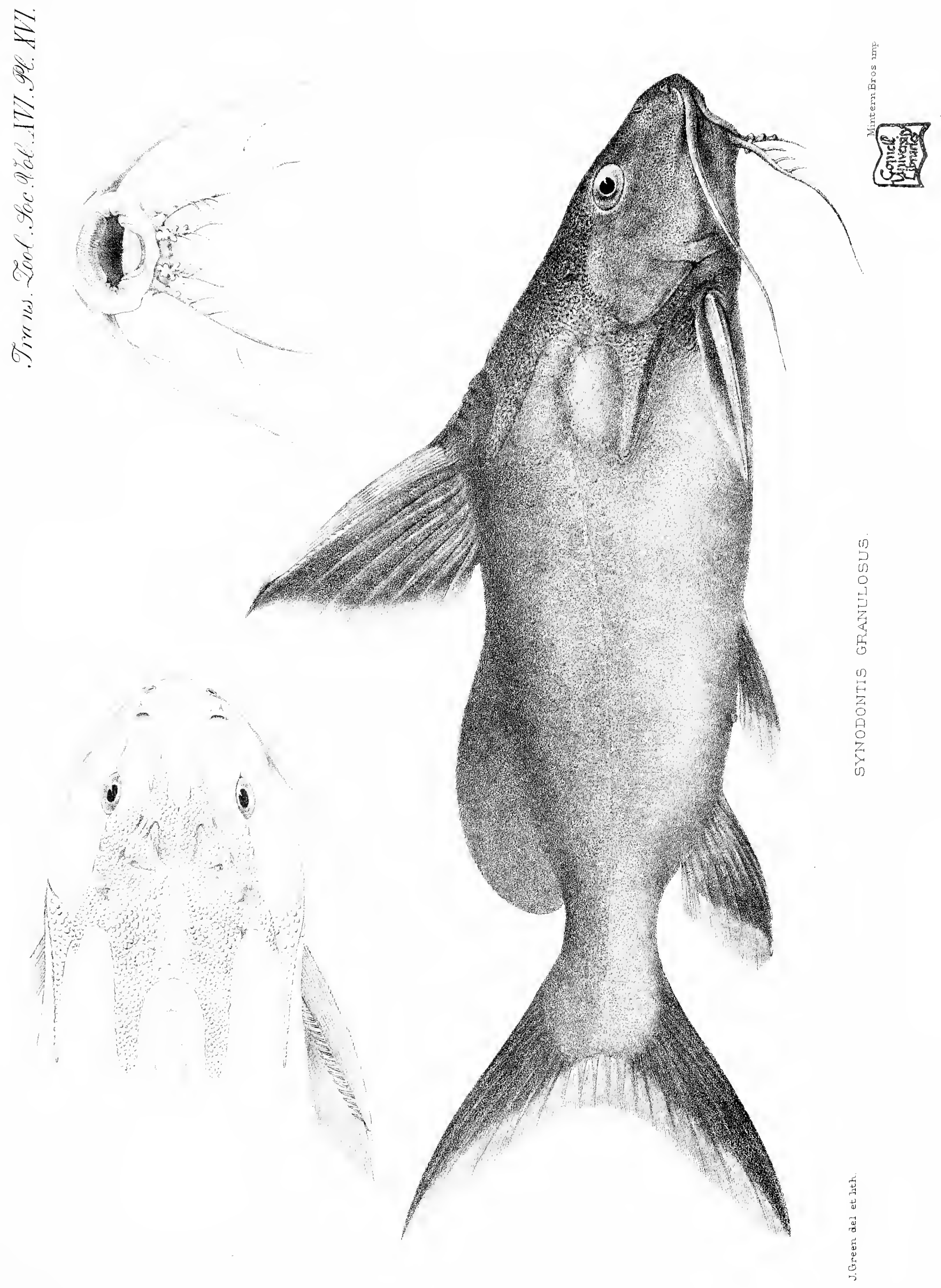



PLATE XVII.

2 c 2 


\section{PLATE XVII.}

Fig. 1. Paratilapia stenosuma, p. 151.

Fig. 2. Bathybates fasciatus, p. 153 . Reduced $\frac{2}{3}$. 

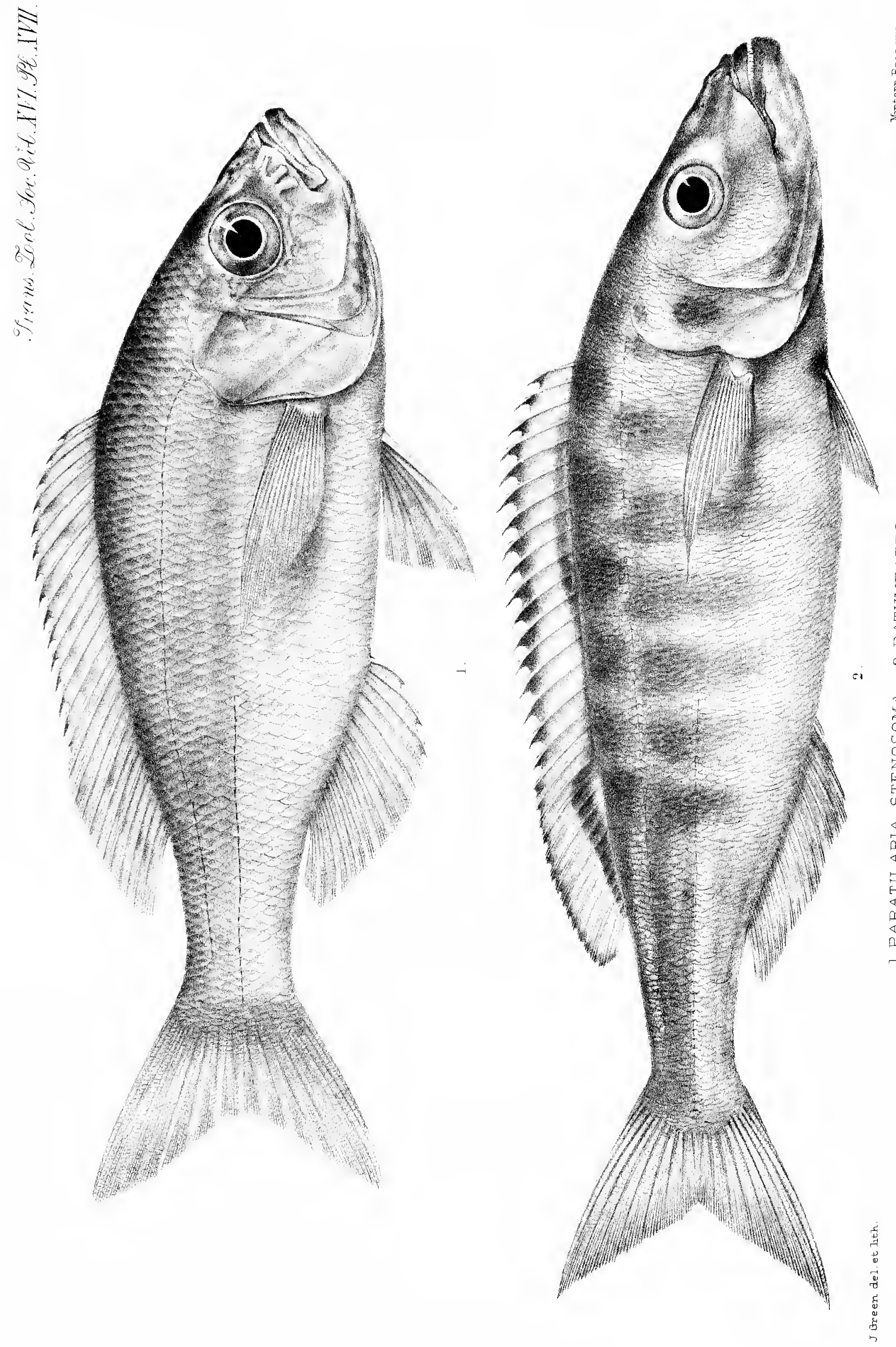

PLATE XVIII. 


\section{PLATE XVIII.}

Fig. 1. Paratilapia vittata, p. $\mathbf{1 5 0 .}$

Fig. 2. Xenotilapia ornatipinnis, p. 154.

Fig. 3. Trematocara unimaculatum, p. 155.

Fig. 4. Tilapia pleurotoenia, p. 157. 


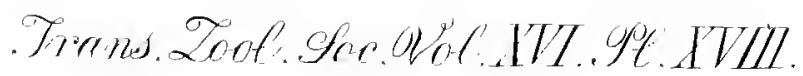

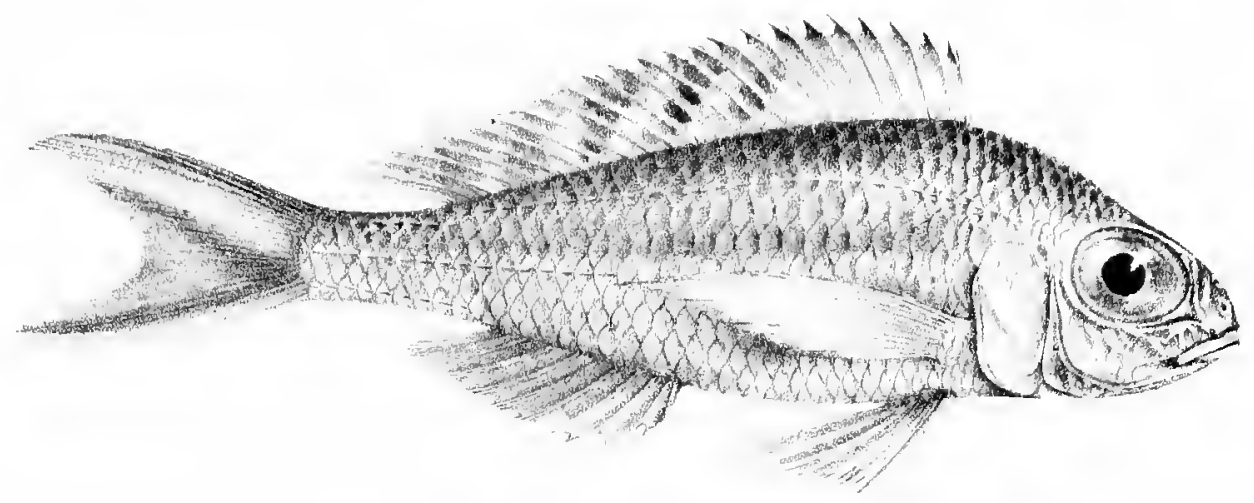

2.
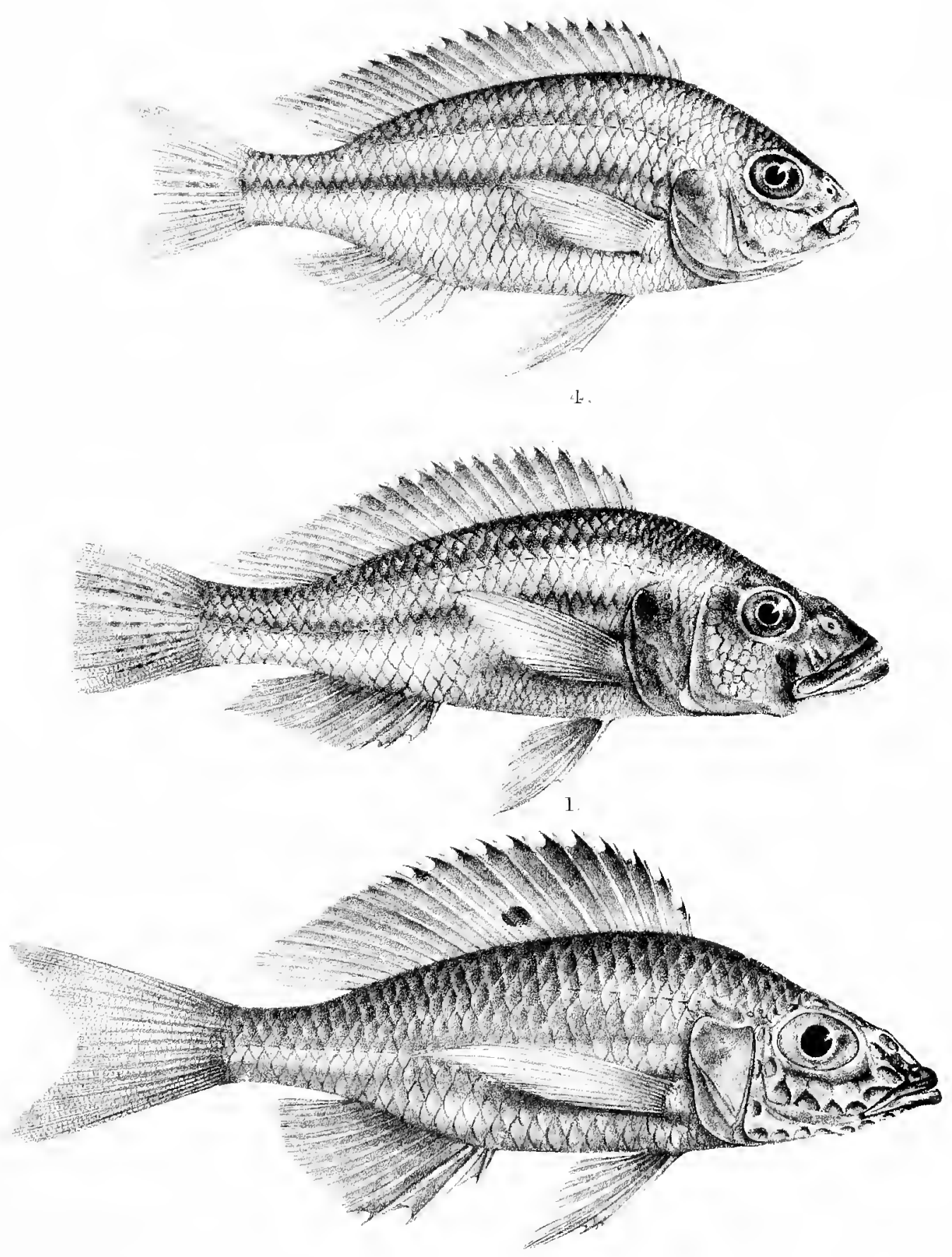

3.

1. PARATILAPIA VITTATA. 2.XENOTILAPIA ORNATIPINNIS.

3.TREMATOCARA UIIMACULATUM. 4.TILAPIA PLEUROTANIA 

PLATE XIX. 


\section{PLATE XIX.}

Fig. 1. Paratilapia nigripinnis, p. 152.

Fig. 2. " aurita, p. 150.

Fig. 3. " $\quad$ calliura, p. 151.

Fig. 4. Ectodus longianalis, p. 154.

Fig. 5. Tilapia boops, p. 158.

Fig. 6. ", trematocephala, p. 157. 


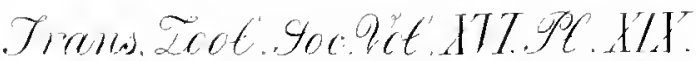
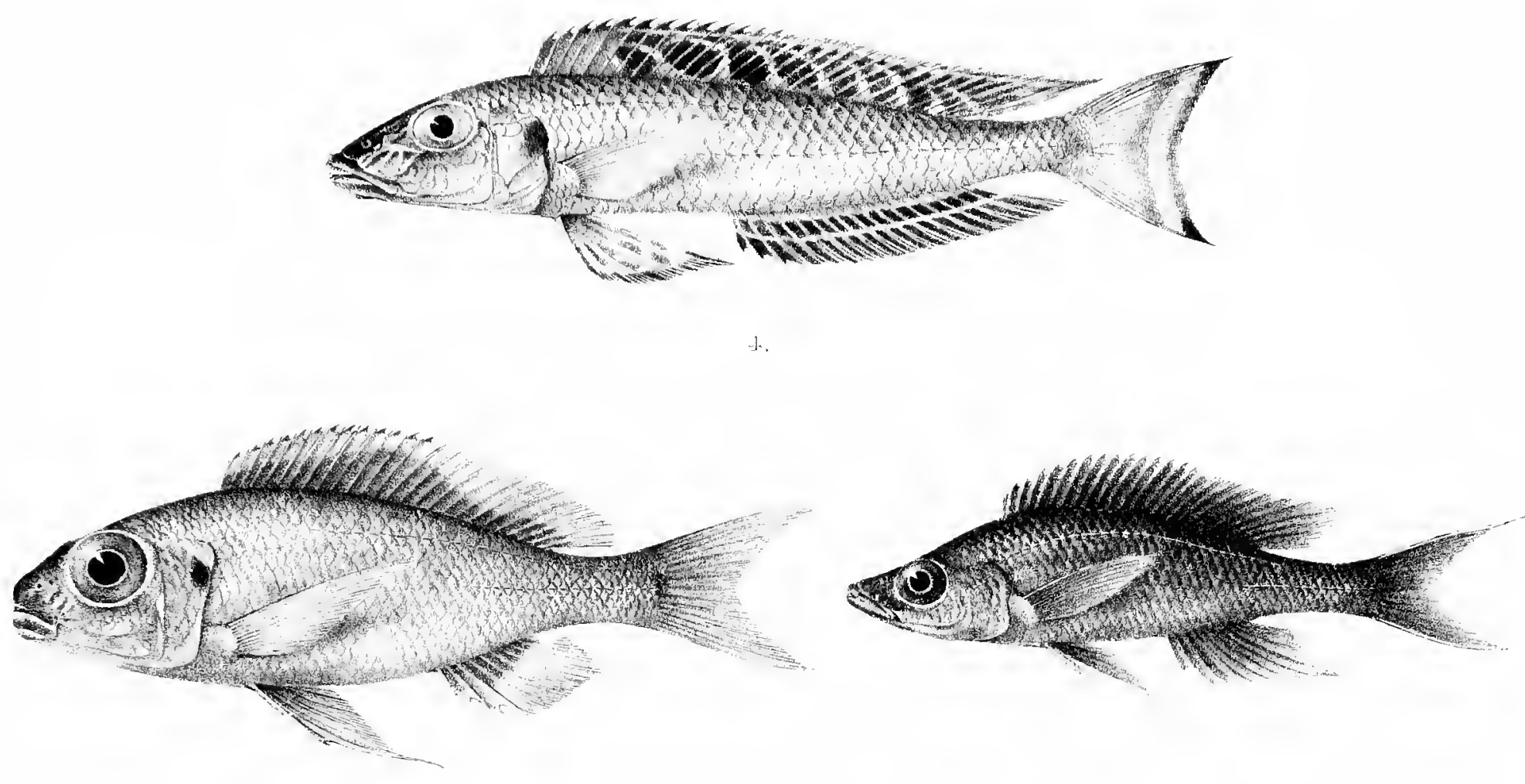

5

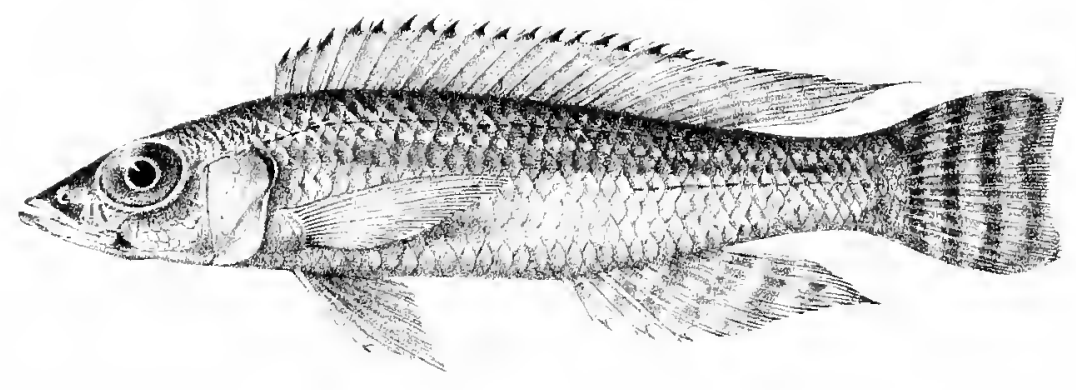

3.

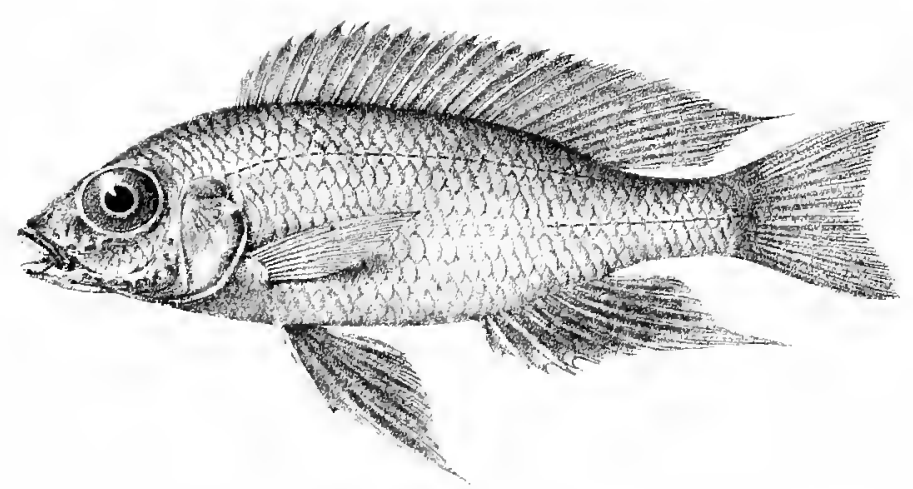

6.

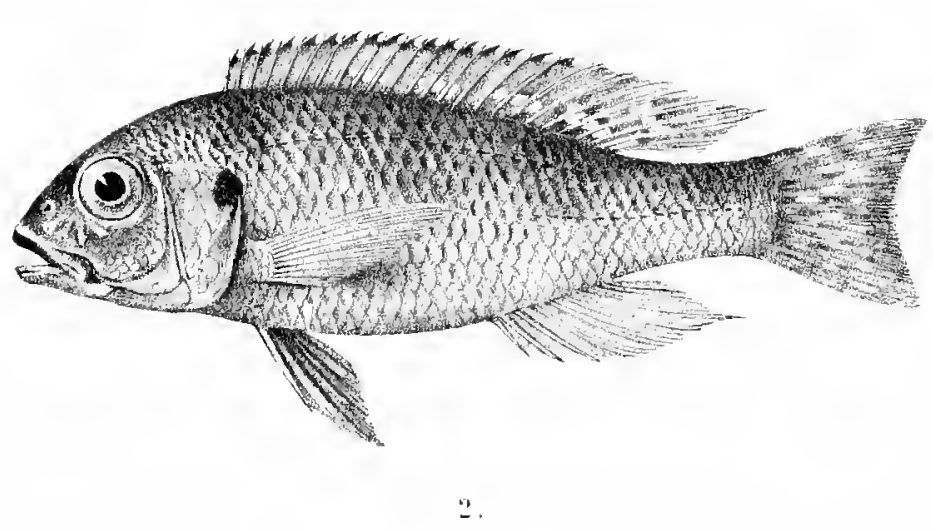

Wintern Bros, inn 



\section{PLATE XX.}

VOL. XVI.-PART III. No. 6.-October, 1901. 


\section{PLATE XX.}

Fig. 1. Gephyrochromis moorii, p. 156.

Fig. $1 a$. , Open mouth. $\times 3$.

Fig. 2. Asprotilapia leptura, p. 159.

Fig. $2 a . \quad$, " Lower view of head. $\times 1 \frac{1}{2}$.

Fig. $2 b . \quad, \quad$, Mouth. $\times 4$.

Fig. 3. Mastacembelus frenatus, p. 159.

Fig. 4. " $\quad$ toeniatus, p. 160. 


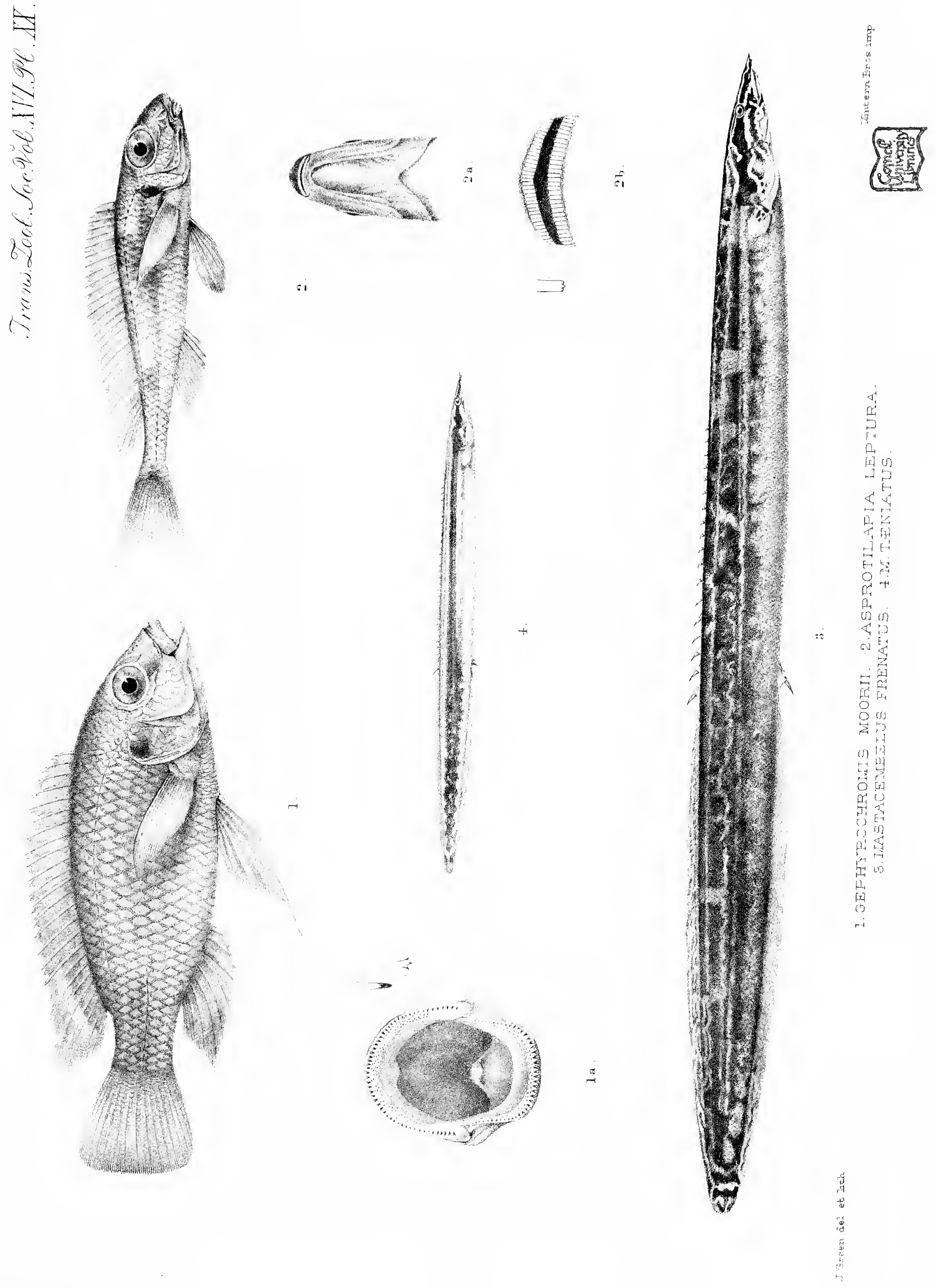





\section{TRANSACTIONS OF THE ZOOLOGICAL SOCIETY OF LONDON (continued).}

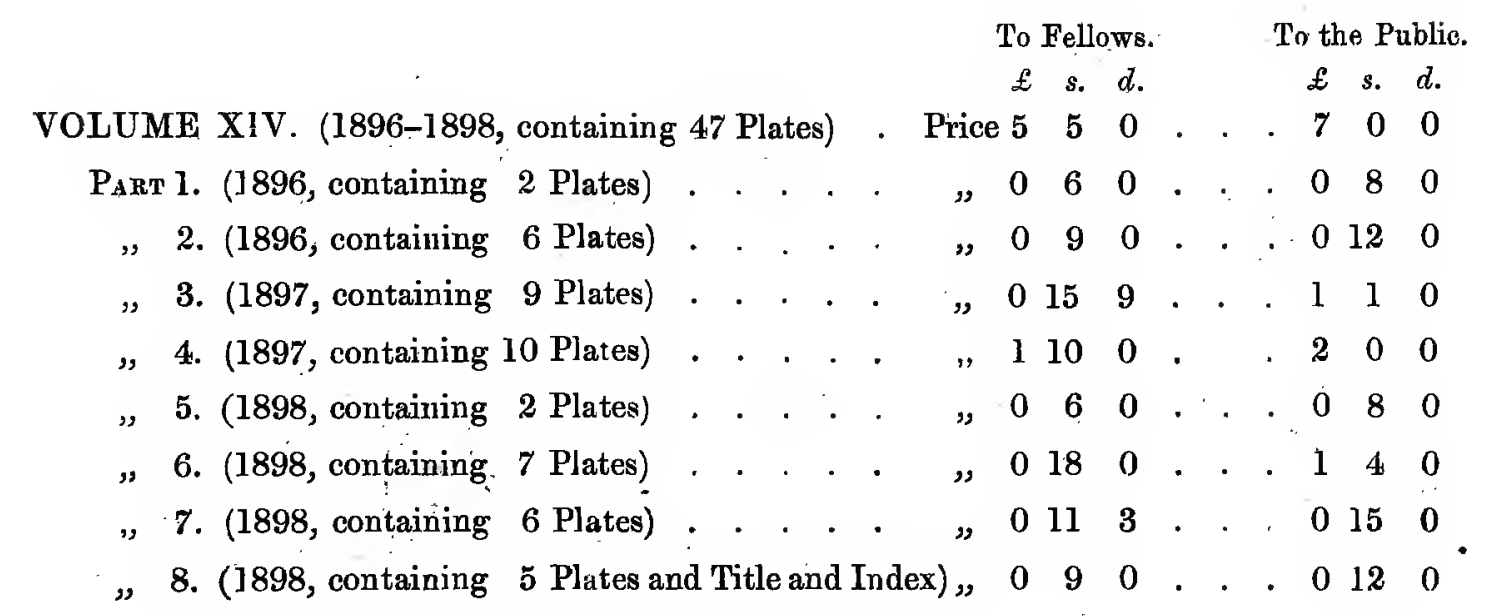

VOLUME XV. (1898-1901, containing 52 Plates) $\therefore \begin{array}{lllllllll} & \text { Price } 5 & 15 & 6 & . & 74 & 0\end{array}$

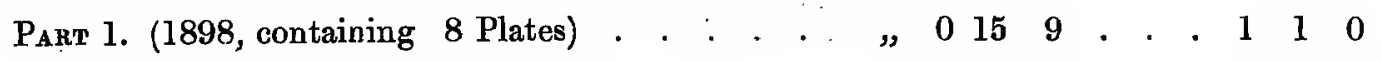

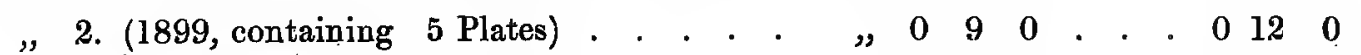

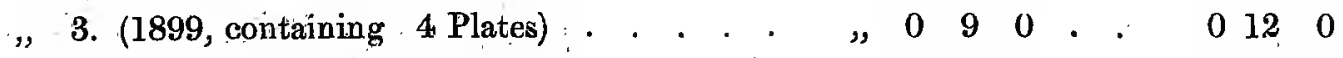

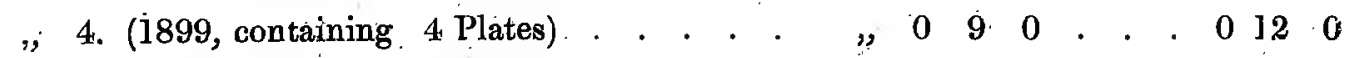

\%5. (1900, containing 24 Plates) . . . . . " " 2126 . . . 3100

„6. (1901, containing 4 Plates) . . . . . $\quad$, 0113 . . . 0150

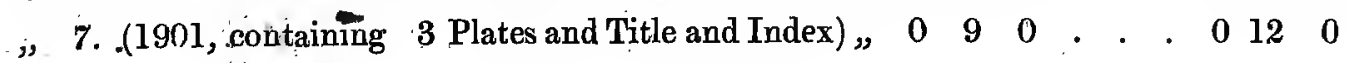

\section{VOLUME XVI.}

PART 1. (1901, containing 6 Plates) . . . . . Price $01800.7 . \quad 140$

2. (1901, containing 5 Plates) . . . . . " „ $0113 . .00150$

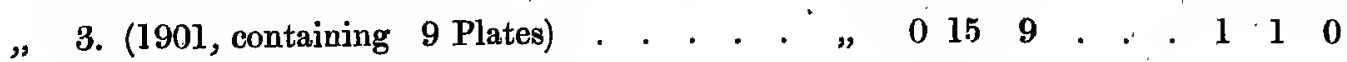




\section{CONTENTS.}

IV. Third Contribution to the Ichthyology of Lake Taganyika-Report on the Collection of Fishes made by Mr.J. E. S. Moore in Lakes Tanganyika and Kivu during his Second Expedition, -1899-1900. By G. A. BoulENGER, K.R.S., F.Z.S. (Plates XII.-XX.) . . . . . . . . . . . . . page 137

.

THE PUBLICATIONS OF THE ZOOLOGICAL SOCIETY OF LONDON.

Tre scientific publications of the Zoological Society of London are of two kinds-" Proceedings," "? published in an octavo form, and "Transactions," in quarto.

According to the present arrangements, the "Proceedings" contain not only notices of all business transacted at the scientific meetings, but also all the papers read at such meetings and recommended to be published in the "Proceedings" by the Committee of Publication. A large number of coloured plates and engravings are attached to each annual volume of the "Proceedings," to illustrate the new or otherwise remarkable species of animals described in them. Among such illustrations, figures of the new or rare species acquired in a living state for the Society's Garden are often given.

The "Proceedings" for each year are issued in four parts; on the first of the months of June, August, October, and April, the part published in April completing the volume for the last half of the preceding year, Commencing from January 1901 they form two half-yearly volumes.

The "Transactions" contain such of the more important communications made to the scientific meetings of the Society as, on account of the nature of the plates required to illustrate them, are better adapted for publication in the quarto form. They are issued at irregular intervals.

Fellows and Corresponding Members, upon payment of a Subscription of $£ 1$ s. before the day of the Anniversary Meeting in each year, are entitled to receive all the Society's Publications for the year. They are likewise entitled to purchase the Publications of the Society at 25 per cent. less than the price charged for them to the Public. A further reductionof 25 per cent. is made upon purchases of Publícations issued prior to 1871 , if they exceed the value of five pounds.

Fellows also have the privilege of subscribing to the Annual Volume of the 'Zoological Record' for a sum of $\mathfrak{E l}$ (which includes delivery in the United Kingdom only), but this privilege only holds good if the subscription is paid before the First of December iu each year.

Such of these publications as are in stock may be obtained at the Society's Office (3.Hanover Square, W.)r.at Messrs. Longmans', the Society's publishers (Paternoster Row; E.C.), or through any bookseller.

October, 1901 .

P. L. SCLATER, Secretary. 


\section{TRANSACTIONS}

OF

\section{THE ZOOLOGICAL SOCIETY \\ OF LONDON.}

Vol. XVII.-PART 6.

\section{LONDON:}

PRINTED FOR THE SOCIETY,

SOLD AT THEIR HOUSE IN HANONER-SQUARE;

AND BY MESSRS. LONGMANS, GREEN, AND CO., PATERNOSTFR-ROW.

October 1906.

Price $30 s_{\text {. }}$ 


\title{
TRANSACTIONS OF THE ZOOLOGICAL SOCIETY OF LONDON.
}

\author{
To Fellows. To the Public.

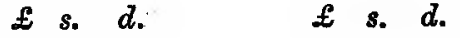 \\ VOLUME I. (1833-1835, containing 59 Plates) . . Price 3136 . . . 418 0* \\ VOLUME II. (1835-1841, containing 71 Plates) . ., $4 \quad 4 \quad 0 \quad 0$. . 5 \\ VOLUME III. (1842-1849, containing 63 Plates) . . „ „ $\quad 3 \quad 8 \quad 3$. . . 41110 0*

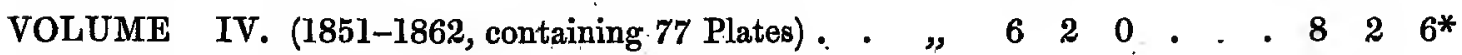

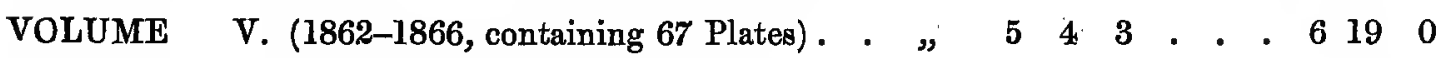

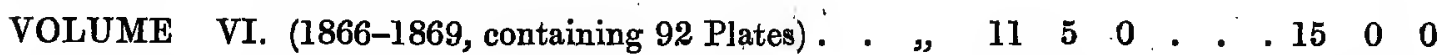

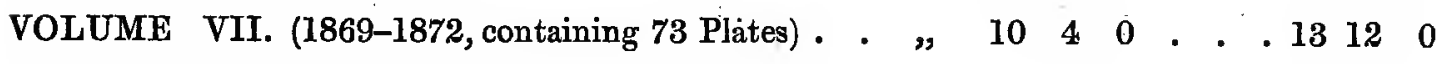

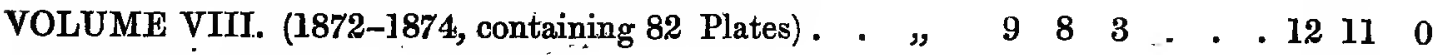 \\ VOLUME IX. (1875-1877, containing 99 Plates) . . „ $\quad \begin{array}{lllllllll}12 & 1 & 6 & . & . & 16 & 2 & 0\end{array}$ \\ VOLUME X. (1877-1879, containing 95 Plates) . „ $10: 0 \quad 3 \quad . \quad .13^{*} 7,0$ \\ GENERAL INDEX, Vols. I. to X. (1833-1879) •,$\quad \begin{array}{llllllllll} & 0 & 7 & 6 & . & . & 0 & 0 & 10\end{array}$ \\ VOLUME XI. (1880-1885, containing 97 Plates) • . y $9120 \quad$. . . 12160 \\ VOLUME XII. (1886-1890, containing 65 Plates). .,$\quad \begin{array}{llllllllllll} & 5 & 8 & 0 & . & . & 7 & 4 & 0\end{array}$ \\ VOLUME XIII. (1891-1895, containiug 62 Plates) . . ” $\quad \begin{array}{llllllllll}6 & 8 & 3 & . & . & 8 & 11 & 0\end{array}$ \\ * No copies of these volumes remain in stock.
}


VI. Fourth Contribution to the Ichthyology of Lake Tanganyika ${ }^{1}$ - -Report on the Collection of Fishes made by Dr. W. A. Cunnington during the Third Tanganyika Expedition, 1904-1905. By G. A. Boulenger, F.R.S., V.P.Z.S.

Received February 6, read March 6, 1906.

\section{[Plates XXX.-XLI.]}

THE last expedition organised out of the funds remaining in the hands of the Tanganyika Exploration Committee was entrusted to Dr. W. A. Cunnington, who left London in March 1904, and returned home in June 1905. The total length of time spent on and around Tanganyika was about 8 months, and collections were made at a great number of localities, marked on the sketch-map on the next page, some of which appear here under a spelling somewhat different from that adopted by Mr. Moore and followed in the previous reports dealing with his results.

Speaking of the fishes alone, I may say that Dr. Cunnington has been highly successful in his efforts, and has fully justified the expectations entertained by the Committee who entrusted him with the mission of forming as complete a collection as possible of the animals and plants inhabiting the great lake. The series brought home by him is larger than any of those from that lake with which it has hitherto been my privilege to deal. The preservation of the specimens is excellent and their value is enhanced by a careful labelling of every one of them, in most cases accompanied by either sketches or notes concerning the life-coloration, on which I have largely drawn in preparing the present account. I have in every case reproduced the native names (mostly of the Ujiji fishermen) consigned in these notes, although in many cases such names appear to be applied regardless of the real specific characters.

Dr. Cunnington has also been so fortunate as to considerably extend the list of Cichlid fishes in which the parents protect their offspring by giving them shelter in the mouth and pharynx. This mode of nursing is illustrated, in the present collection, by examples of seven species, viz.:-Paratilapia pfefferi, Pelmatochromis polylepis, Pelmatochromis pleurospilus, Enantiopus longianalis, Simochromis diagramma, Tilapia dardennii, and Eretmodus cyanostictus. Mr. Moore had previously made us

${ }^{1}$ For the third contribution, of. Tr. Z. S. xri. 1901, p. 137.

YOL. XVIr.-PART VI. No. 1.-October, 1906. 


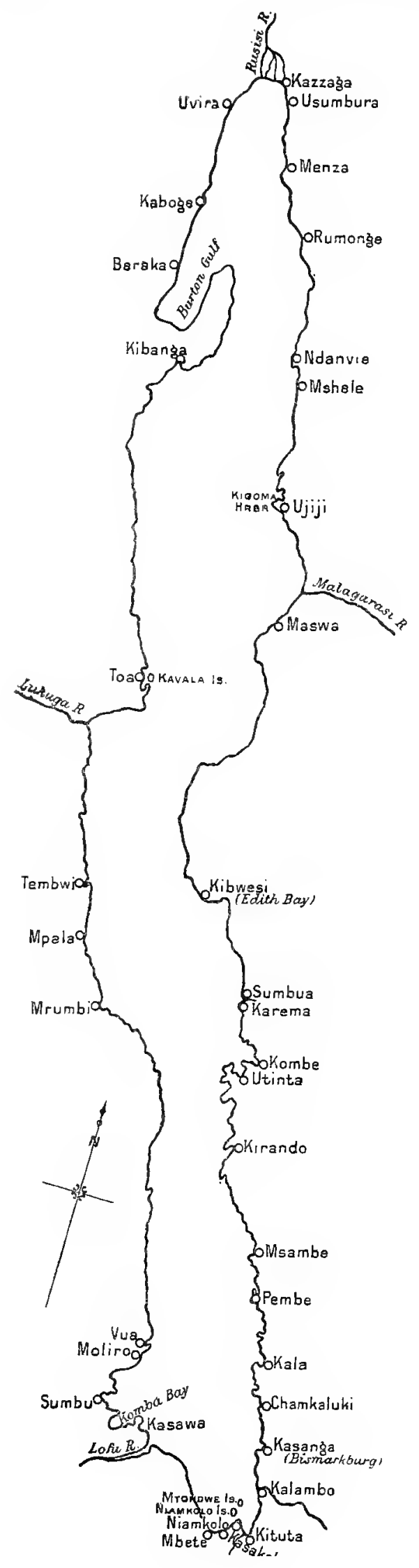

acquainted with similar habits in Enantiopus longianalis and Tropheus moorii. I find in Dr. Cunnington's notes an interesting entry referring to this matter: "The natives say it is always the female, in the cases where one of the parents takes the eggs in the mouth." This is not only confirmed by the specimens in the collection, whenever I have been able to ascertain the sex, but agrees entirely with a statement made by me four years ago ${ }^{1}$ to the effect that so far as I could speak from personal observation, having tested the sex of a great number of specimens of Tilapia nilotica and strigigena from the Nile, it is invariably the female who thus carries the eggs. This was in contradiction to statements made by Lortet and by Günther, who ascribed this habit to the male in the species of the same genus with which they had dealt. I have, however, since had occasion to examine the specimen of Chromis (Tilapia) philander sent by Mr. Nendick Abraham to Dr. Günther 2, and was able to satisfy myself from autopsy that it is a female and not a male; whilst Dr. Pellegrin has ascertained the female sex of a specimen with eggs in the mouth presented to the Paris Museum by Dr. Lortet as his Chromis paterfamilias (= Tilapia simonis). Further observations by Dr. Pellegrin ${ }^{3}$ on Tilapia galilaca and Pelmatochromis lateralis, by Mr. Schoeller on Paratilapia multicolor, and by myself on Tilapia natalensis have led to the same result. It therefore remains unproved whether in any of the African or Syrian Cichlids the buccal "incubation," as it has been called by Dr. Pellegrin, devolves on the male; the instances previously adduced

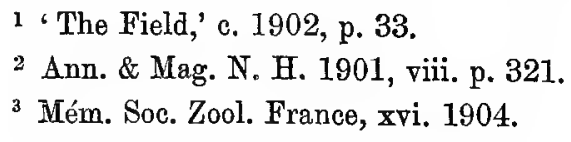


being either controverted or nnsupported by the only reliable evidence-an examination of the genital glands ${ }^{1}$.

In my last report I expressed the opinion that, notwithstanding the exertions of Mr. Moore and the officers in the service of the Congo Free State, not more than onehalf of the species of Fishes existing in Lake Tanganyika was then known to Science. The valuable collection formed by Dr. Cunnington goes a long way towards the fulfilment of this prediction. Mr. Moore's first collection, made in 1895-96, contained about 90 Fishes, referred to 33 species, 25 of which were described as new. His second collection, made in 1899-1900, contained 180 examples of 48 species, 22 of which were new. Dr. Cunnington succeeded in bringing home 300 specimens, referred to 84 species, 27 of which are here described for the first time. No doubt many more species remain to be discovered.

The following Table, giving a complete list of the Tanganyika fishes, will show the order in which they have been discovered. Column 1 indicates the species discovered by Mr. Coode Hore and described by Dr. Günther in 1893; column 2 the species in Mr. Moore's first collection; column 3 those in the various small collections formed by the officers of the Congo Free State; column 4 those in Mr. Moore's second collection; and column 5 those in Dr. Cunnington's collection. The names of endemic genera and species are printed in italics.

1 [Since the reading of this Report I have been able to considerably extend my observations on the nursinghabits of these fishes, and in every case the specimen carrying eggs or young in the mouth has provod to be of the female sex.

First, Mr. E. Degen has brought back from Lake Victoria a large and valuable series of Cichlid fishes, many of which represented new species which have been described in the "Annals and Magazine of Natural History' for May 1906. The maternal solicitude was observed in three species, viz. :-Haplochromis ishmaeli, Paratilapia serranus, and Tilapia martini.

Secondly, Lord Walsingham, when at Biskra in February and March last, was so kind as to colloct for me a large number of Haplochromis clesfontainesii in a tepid spring at Ain Oumash, and most of the females, which do not appear to reach so large a size as the males, had the mouth and pharynx full of eggs or embryos. The egg of this fish is not perfectly round, the upper pole being somewhat pointed; the vitelline sac, when hanging from the embryo, is pyriform in shape.

And, thirdly, Dr. Günther has been so good as to hand over to me, for the British Museum, a further series of Tilapia philander, together with some T'. natalensis, which he had recoived from the Rev. N. Abraham, several of which have eggs in the mouth as well as in the genital glands.-23.6.06.] 


\section{Polypterider.}

1. Polypterus congicus Blgr. 1898

\section{LEPIDOSIRENIDA.}

2. Protopterus æthiopicus Heck. 1851

\section{Mormsrid az.}

3. Marcusenius tanqanicanus Blgr. 1906.

4. Mormyrus longirostris Peters, 1852

\section{Clupeidat.}

5. Pellonnla miodon Blor. 1906

Characinide.

6. Hydrocyon lineatus Blkr. 1863

7. Alestes macrophthalmus Gthr. 1867

8. , rhoclopleura Blgr. 1906

9. Citharinus gibbosus Blgr. 1899

1.

2.

3.

4.

5.

\section{CyPRINIDA}

10. Labeo cylindricus Peters, 1852

11. Varicorhinus tunganicce Blgr. 1900

12. Barbus platyrhinus Blgr. 1900

14. " $"$ tropidolepis Blgr. $1900 \ldots \ldots \ldots \ldots$

15. Barilius moorii Blgr. 1900

16. " tanganicice Blgr. 1000

17. Ncobola minuta Blgr. 1906 .

\section{SILURID番.}

18. Clarias robecchii Vincig. $1893 \ldots \ldots \ldots \ldots \ldots$

19.

20. Dinotopterus cunningtoni Blgr. 1906

21. Chrysichthys cranchii Leach, 1810 . .

22. " myriodon Blgr. 1900 .

23. " brachynema Blgr. $1900 \ldots \ldots$

24. $\quad " \quad$ sianenna Blgr. $1906 \ldots \ldots \ldots$

25. Phyllonemus typus Blgr. $1906 \ldots \ldots \ldots \ldots$

26. Auchenoglanis occidentalis C. \& V. $1840^{\circ}$.

27. Amphilius platychir Gthr. 1864

28. Synodontis granulosus Blgr. $1900 \ldots \ldots \ldots$

29 . " multipunctatus Blgr. 1898 .

30. ", melanostictus Blgr. 1906

31. Malopterurus electricus Gm. 1789

\section{Cyprinodontid}

32. Haplochilus pumilus Blgr. 1906 .

33.

tancanicanus Bjgr. 1898 


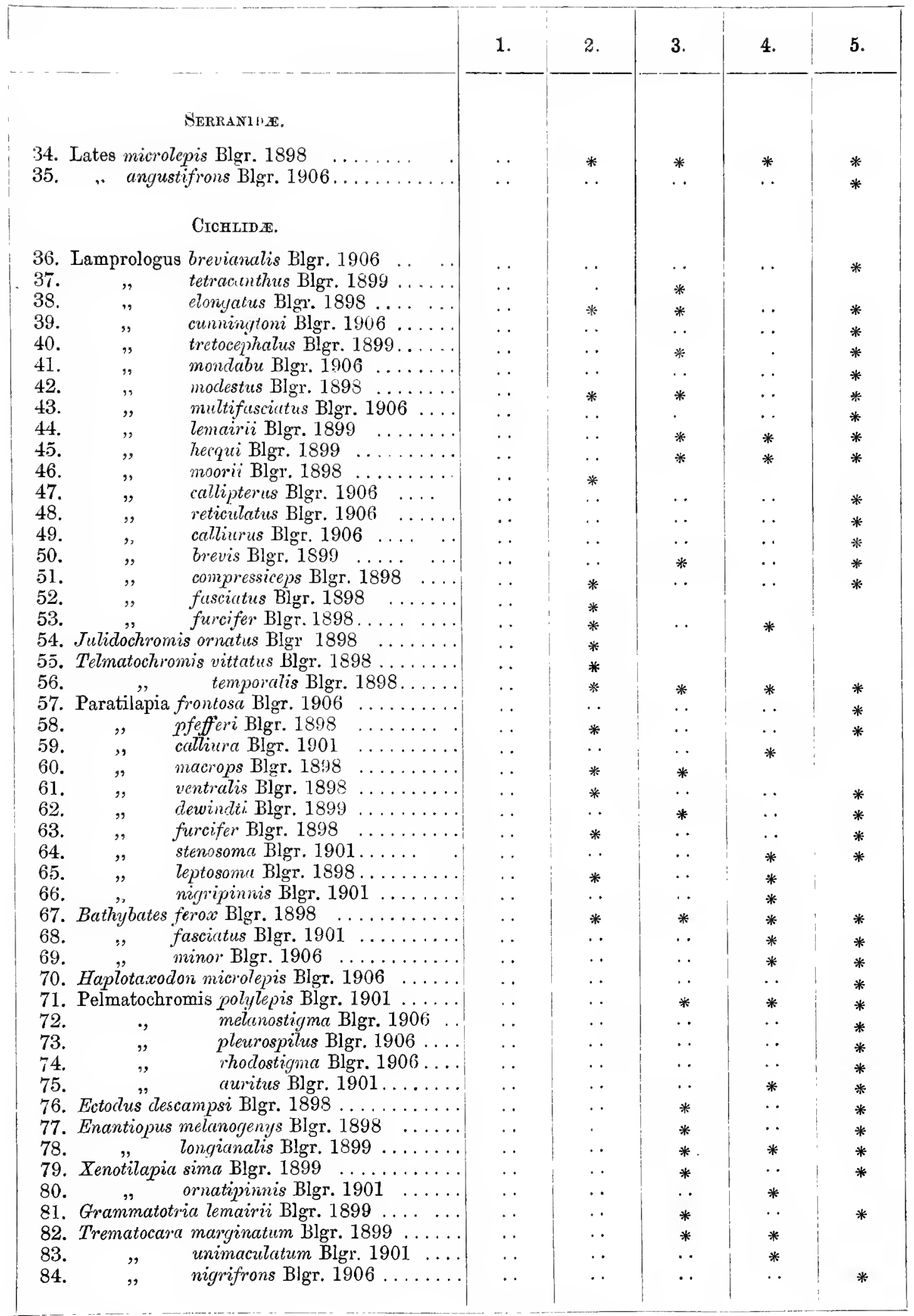




\begin{tabular}{|c|c|c|c|c|c|}
\hline & 1. & 2. & 3. & 4. & 5. \\
\hline \multicolumn{6}{|l|}{ CICHLID s (continued). } \\
\hline 85. Gephyrochromis moorii Blgr. $1901 \ldots \ldots \ldots$ & .. & .. & . & * & \\
\hline 86. Tropheas moorii Blgr. $1898 \ldots \ldots \ldots \ldots \ldots$ & . & * & . & . & * \\
\hline 87. $", \quad$ annectens Blgr. $1900 \ldots \ldots \ldots$ & . & $\cdots$ & * & & \\
\hline 88. Simochromis diagramma Gthr. $1893 \ldots \ldots$ & * & * & $\cdots$ & * & * \\
\hline 89. Tilapia nilotica & . & . & . & - & * \\
\hline 90.,$\quad$ burtoni Gthr. $1893 \ldots \ldots \ldots$ & * & . & * & . & * \\
\hline latifrons Blgr. $1906 \ldots \ldots \ldots \ldots \ldots$ & . & . & . & .. & * \\
\hline 92. " horii Gthr. $1893 \ldots \ldots \ldots \ldots$ & * & . & * & . & * \\
\hline 93. " & .. & . & * & * & * \\
\hline 94. , labiata Blgr. $1898 \quad \ldots$ & . & * & * & * & * \\
\hline pleurotcenia Blgr. $1901 \ldots \ldots \ldots \ldots$ & . & $\cdots$ & . & $*$ & \\
\hline trematocephala Blgr. $1901 \quad \ldots \ldots \ldots$ & . & $\cdots$ & . & * & \\
\hline 97. " microlepis Blgr. $1899 \ldots \ldots \ldots \ldots$ & . & $\cdots$ & $*$ & * & * \\
\hline 98. " $"$ boops Blgr. $1901 \ldots \ldots \ldots \ldots$ & . & . & . & $*$ & \\
\hline 99. „, grandoculis Blgr. 1899......... & . & $\ldots$ & * & . & * \\
\hline 100. Petrochromis polyodon Blgr. 1898 ....... & . & * & . & . & * \\
\hline 101. $\because \quad$ tanganica Gthr. $1893 \ldots \ldots \ldots$ & * & $\cdots$ & $*$ & $*$ & * \\
\hline 102. Cunningtonia longiventralis Blgr. $1906 \ldots$ & . & $\cdots$ & $\cdots$ & . & * \\
\hline 103. Asprotilapia leptura Blgr. 1901 ........ & . & $\cdots$ & . & * & \\
\hline 104. Eretmodus cyanostictus Blgr. 1898 . . . . . . & . & ** & * & . & * \\
\hline 105. Spathodus erythrodon Blgr. $1900 \quad \ldots \ldots \ldots$ & . & . & * & & \\
\hline 106. Perissodus microlepis Blgr. $1898 \ldots \ldots \ldots$ & . & * & & & \\
\hline 107. Xenochromis hecqui Blgr. $1899 \quad \ldots \ldots$ & . & $\cdots$ & * & * & * \\
\hline 108. Plecodus paradoxus Blgr. 1898 ..... & $\cdots$ & $\cdots$ & * & . & * \\
\hline \multicolumn{6}{|l|}{ Mastacembelid } \\
\hline 109. Mastacembelus frenatus Blgr. 1901 ....... & . & .. & . & * & \\
\hline 110. $\quad, \quad$ moorii Blgr. $1898 \ldots \ldots \ldots$ & . & * & . & . & * \\
\hline 111. $\quad " \quad$ cunningtoni Blgr. $1906 \ldots$ & . & $\cdots$ & . & . & * \\
\hline ellipsifer Blgr. 1899 ..... & . & . . & * & & \\
\hline tanganice Gthr. $1893 \ldots \ldots$ & * & & & & \\
\hline toniatus Blgr. 1901 . . . . . & $\cdots$ & . & .. & * & * \\
\hline 115. $\quad " \quad$ ophidium Gthr. 1893 & $*$ & . & . & . & * \\
\hline
\end{tabular}

A glance over this list shows that one of the six species discovered by Mr. Coode Hore (Mastacembelus tanganica) and six of those in Mr. Moore's first collection are unrepresented in the collections subsequently made.

Apart from many important additions to our knowledge, the collection now worked out calls for the following modifications to the conclusions previously arrived at as to the general character of this remarkable fish-fauna:-

Two new generic types of Siluridæ are here described, all previously known autochthonous genera falling under the family Cichlidæ.

One species of Cichlids, Tilapia nilotica, of wide distribution (Jordan, Nile, East and West Africa), previously known from Lake Kivu, is, with T. burtoni, also found in Lake Kivu, the only non-endemic species of that family the occurrence of which has been ascertained. 
One species widely distributed in East Africa, Labeo cylindricus, is added to the list of Cyprinidæ, all previously known species being endemic. Neobola, ranging over North-east Africa and Lake Victoria, has yielded a third species representing this genus of Cyprinidæ in Lake Tanganyika.

An Alestes previously regarded, from insufficient material, as identical with a Nile and West-African species, is now found to be distinct. The Characinidæ can therefore no longer be said to be all non-endemic.

A small Cyprinodontid (Haplochilus pumilus) was discovered almost simultaneously by Dr. Cunnington in Lake Tanganyika and by Mr. E. Degen in Lake Victoria.

And, finally, representatives of two families widely distributed in tropical Africa, the Mormyridae and the Clupeido, have been added. The discovery of Mormyridoe is of particular interest, as their supposed absence was regarded as a striking negative feature of the great lake.

These data, however, only further emphasize the truly African freshwater and modern character of the fauna of Lake Tanganyika, a subject with which I have fully dealt, from the ichthyological point of view, in an Address read at the British Association Meeting in South Africa last summer, and I have nothing to alter in the general conclusions I had arrived at before studying Dr. Cunnington's collection.

Dr. Cunnington supplies the following note on the methods of fishing observed by him :- "Almost the whole shore of this big lake is inhabited by a fishing population, and large quantities of fish of the most diverse kinds are obtained from the well-stocked water. The lake-shore inhabitants belong, however, to a number of different tribes, so that the methods of fishing adopted, and the kinds of fish most highly prized, vary somewhat in the different regions. While most, if not all, of the Tanganyika fish are good for food, the Polypterus, for instance, is not eaten by the Wajiji, and, on the other hand, the large Siluroids, with their rich oily flesh, are usually much valued by the natives for eating. Again, towards the north end of the lake, the small whitebaitlike Clupeid, Pellonula miodon, is a particularly favourite dish.

"Perhaps the commonest method of fishing is by means of a net laid out from the shore in a semicircle and drawn in from both ends. In some cases this may be merely a flat wall of net-work, buoyed above and weighted below, though even then not more than three or four feet in depth, while in other cases it may be still shallower, but furnished at intervals with a series of pockets. On parts of the western shore a small and singularly inefficient net of this type is employed, consisting of but two such pockets of small dimensions in the middle, and on each side a long-shaped ring converted into a grating by flat strips of bark.

"Fishing is also carried on in many parts of the lake by the aid of a long line bearing a series of baited hooks at intervals. This is essentially in the nature of a surface-line, being buoyed at each end, and the line is baited overnight and hauled in in the morning. Fishing with rod and line is but little practised, and for this the natives 
appear never to use a float, although that is the general custom on Victoria Nyanza. When using hook and line alone a bait of stiff paste is used, and it is especially Characinids which are caught in this manner.

"Torch-light fishing goes on to a considerable extent in various parts of the lake, the larger fish being speared and the smaller caught in hand-nets as they are attracted to the light. At the north end, in particular, an important fishery is carried on for 'dagaa,' a young Clupeid which swims in shoals. Owing to the scarcity of firewood, large bundles of dried reeds are tied together to form a gigantic torch, which projects over the bows of the canoe and is gradually pushed forwards as it burns away. The fish are netted and brought in large quantities to the native markets, while some are sun-dried and disposed of at considerable distances from the lake.

"Finally, there are different kinds of traps used around Tanganyika. Small conical wicker traps are placed in the rivers and streams, while across the latter, not far from the lake, may be built an elaborate system of traps and barriers to catch the fish proceeding down the stream. Out in the lake itself, particularly towards the southern end, large trilobed basket-traps are used for the purpose of catching the big Silurid 'singa.' The trap is suspended from a float, a few feet under the surface, and is baited with some vegetable substance. In certain districts a great number of such floats may be seen dotting the surface of a bay or inlet."

$$
\text { P OLY P T E R I D E. }
$$

\section{Polypterus congicus Blgr.}

A single male specimen, 620 millim. long, from Kituta. Native name Munkunga. Dr. Cunnington measured a larger specimen, 710 millim. long. The fish occurs also in the rivers.

14 spines in the dorsal; 56 scales in a longitudinal series, 46 round the body, 13 between the occiput and the origin of the dorsal. The azygous shield between the nasal bones is present. Dr. Cunnington describes the colour as greenish grey above, shading off to lighter below, belly with pinkish tinge; 8 or 9 black blotches along side of body; black spots on side of head; paired fins with dark spots.

\section{LEPI D OSIRENI D 瓜。}

\section{Protopterus athiopicus Heck.}

One specimen, measuring 485 millim., taken in a native-made wicker trap, baited with vegetable matter, in the Kakonde River, near its mouth in Mtondwe Bay, was brought home by Dr. Cunnington, who also observed another specimen, measuring 970 millim., in a river at Moliro. The fish has not been found in the lake itself, and the natives, who call it Sompo, catch it in small muddy streams and say (at Mpala) 
that they sometimes come across it when digging graves. It is much feared for its bite. Although captured by vegetable bait (cassava, a surt of tuber), a specimen opened by Dr. Cunnington contained partially digested fish in the stomach.

This is the first specimen from the borders of Lake Tanganyika which falls under the eyes of an ichthyologist, and it confirms the provisional identification of the species (see Boulenger, Poiss. Bass. Congo, p. 38). The specimen figured by Moore in his 'Tanganyika Problem,' p. 153, is from Lake Albert Edward. The following notes are taken from Dr. Cunnington's specimen :-

Depth of body $8 \frac{1}{3}$ times in total length; length of head $4 \frac{4}{5}$ times in distance from end of snout to vent; diameter of eye 13 times in length of head; dorsal fin originating a little nearer to vent than to occiput; 60 scales in a longitudinal series from the gillopening to above the vent, 42 round the body; vent on the left side. Dr. Cunnington describes the coloration as "mottled grey and black, darker above; sinuous lines of brown on the dorsal region and on the tail; tail with large black blotches on a grey ground ; belly mottled grey and flesh-colour, with a pinkish tinge all over."

M ORM Y R I D A.

3. Marcusenids tanganicanus, sp. $n$. (Plate XXX. fig. 1.)

Depth of body $3 \frac{1}{4}$ to $3 \frac{1}{2}$ times in total length, length of head $4 \frac{1}{3}$ to $4 \frac{2}{3}$ times. Head as long as deep, not quite twice as long as broad; snout as long as or a little shorter than the eye, rounded, projecting beyond the mouth, which is small and a little anterior to the vertical of the nostrils; teeth bicuspid, 5 in the upper jaw, 6 in the lower; nostrils on a line with lower border of eye, nearer the latter than the end of the snout; eye $4 \frac{1}{3}$ to $4 \frac{1}{2}$ times in length of head, about once and $\frac{1}{2}$ in interocular width. Dorsal 31-34, considerably shorter than its distance from the head, anterior rays longest. Anal 23-25, originating below 8 th to 10 th rays of dorsal, equally distant from base of ventral and from root of caudal; anterior rays longest, especially in the males, in which the anterior half of the fin forms a rounded lobe. Pectoral pointed, as long as or a little shorter than the head, extending beyond base of ventral. Caudal fin scaly at the base, with pointed lobes. Caudal peduncle twice and $\frac{1}{4}$ to twice and $\frac{2}{5}$ as long as deep, a little shorter than the head. 65 to 67 scales in the lateral line, $\frac{17-19}{21-22}$ in a transverse series on the body, $\frac{12-15}{12-14}$ in a transverse series between dorsal and anal, 12 round caudal peduncle. Uniform greyish above, silvery white beneath; dorsal and anal fins whitish at the base, grey distally.

Total length 160 millim.

Two specimens from Sumbu, and one taken in a river at Msamba. Native name: Zoveruz.

This species is very closely allied to, and exactly intermediate between, $M$. discorhynchus Peters, from the Zambesi and Lake Nyasa, and $M$. petherici Blgr., from the VOL. XVII.-PART VI. No. 2.-Oatober, 1906. 
Nile. It differs from the first in the mouth being a little more anterior, in the shorter dorsal fin with 31-34 rays instead of 34-36, and in the depth of the caudal peduncle being contained less than twice and a half in its length; from the second in the caudal peduncle being more than twice as long as deep and surrounded by 12 scales instead of 14 .

\section{Mormyrus longirostris Peters.}

A single specimen, 330 millim. long, from Sumbu. Native name: Domodomo. Said to grow to nearly three feet. Dorsal $75,5 \frac{1}{2}$ times as long as anal; anal 18; 26 scales round caudal peduncle. Dr. Cunnington describes the coloration as "Grey above, lighter to white below, darker on top of head, with darker blotches along middle of side; tail darker, with some patches of red; two brown spots below the eye; ventrals reddish, grey distally."

M. longirostris, which is known from the Zambesi and the Congo, is so closely related to $M$. caschive, from the Nile, that it should perhaps be regarded as merely a variety of the latter.

\section{CLUPEID E.}

5. Pellonula miodon, sp. n. (Plate XXX. fig. 2.)

Depth of body $4 \frac{2}{3}$ to $5 \frac{1}{2}$ times in the total length, length of head $3 \frac{2}{3}$ to 4 times. Snout obtusely pointed, as long as the eye, the diameter of which is contained $3 \frac{1}{3}$ to $3 \frac{1}{2}$ times in length of head and equals once and $\frac{1}{2}$ to once and $\frac{2}{3}$ interorbital width; chin projecting beyond the snout; maxillary extending to below anterior border or anterior fourth of eye; teeth small, canines confined to anterior extremity of mandible. Gill-rakers long and slender, closely set, 35 to 40 on lower part of anterior arch. Dorsal 15-16, equally distant from centre or posterior border of eye and from root of caudal; longest rays about $\frac{1}{2}$ length of head. Anal 16-17, a long way behind the dorsal, nearer to root of caudal than to base of ventrals. Pectoral $\frac{3}{5}$ length of head, widely separated from the ventral. Ventral inserted below anterior third or middle of dorsal. Caudal deeply forked, with pointed lobes. Caudal peduncle once and $\frac{1}{2}$ to once and $\frac{2}{3}$ as long as deep. 45 to 48 scales in a longitudinal series, 14 in a transverse series; 19 or 20 keeled scutes between isthmus and ventrals, 10 or 11 between ventrals and anal. Olive above; silvery below, with a blue indistinct lateral band; dorsal and caudal greyish, other fins white.

Total length 140 millim.

Several specimens from Ndanvie, Tembwi, Vua, Mbete, Niamkolo Id., and Kasakalawa. Native names: Lumbu, Sembe, and Dagaa. This is, no doubt, the little fish "very like Whitebait" mentioned by Livingtone ('Last Journals,' vol. ii. p. 17) as the Dagala or Nsipé of Lake 'Tanganyika, which, in my previous ignorance of any sort of Clupeid in 
that lake, I had suggested might be the Cyprinodont Haplochilus tanganicanus. Whether the statement of the natives that it carries its eggs in its mouth is true or is based on confusion with some other fish cannot at present be decided; but the material at hand offers no evidence in its favour.

Stanley ('How I found Livingtone,' p. 530) also speaks of it as the Dogara, a species of whitebait, which is caught in great nets by the thousand and spread out in the sun to dry, and exported, salted, even as far as Unyanyembe.

The Clupeids are represented in the fresh waters of tropical Africa by three closely related genera: Pellonula Gthr., Odaxothrissa Blgr., and Microthrissa Blgr. Of the first, to which the Tanganyika fish belongs, two species only were known, inhabiting West Africa and the Congo. The principal characters distinguishing the three species with which we are now acquainted are contrasted in the following "key":-

I. Dorsal 15-17, originating at equal distance from end of snout and from base of eaudal fin, or a little nearer the latter; lower jaw projeeting beyond the upper.

Depth of body not more than 4 times in total length; keeled ventral seutes

13-15 + 9-10; anal originating a short distance behind vertical of dorsal. P. vorax Gthr. Depth of body $4 \frac{2}{3}$ to $5 \frac{1}{2}$ times in total length ; keeled ventral scutes $19-20+$

10-11; anal originating a long way behind dorsal . . . . . . P. miodon Blgr.

II. Dorsal 13-14, originating mueh nearer end of snout than base of caudal fin; upper jaw projecting beyond the lower'; keeled ventral scntes 12-13+12; anal originating a long way behind dorsal . . . P. acutirostris Blgr.

\section{CHA R A C I I D $\mathbb{E}$.}

6. Hydrocyon lineatus Blkr.

Kituta. Native name: Sokonto.

\section{Alestes macrophthalmus Gthr.}

Several specimens from Niamkolo, Mtondwe Bay, and Kituta. Native names: Manji, Mianga, and Mowanzi. Grows to a length of 560 millim.

8. Alestes Rhodopleura, sp. n. (Plate XXX. fig. 3.)

Depth of body 4 times in total length, length of head 4 to $4 \frac{1}{2}$ times. Head longer than deep, nearly twice as long as broad, its width much less than its length to the occiput; snout rounded, feebly projecting beyond the lower jaw, once and $\frac{1}{3}$ diameter of eye, which is 4 times in length of head; adipose eyelid very short; interorbital width nearly half length of head ; maxillary not extending to below anterior border of eye; 18 teeth in the upper jaw, 8 in the outer row of the lower jaw ; length of lower border of second suborbital equal to or a little more than diameter of eye. 
Gill-rakers moderately long, 18 or 19 on lower part of anterior arch. Dorsal II 8, behind vertical of base of ventrals, originating much nearer root of caudal than end of snout, longest ray about $\frac{3}{4}$ length of head. Adipose fin small, about twice as far from rayed dorsal as from root of caudal. Anal III 12-13. Pectoral as long as head, not reaching ventral. Caudal forked. Caudal peduncle once and $\frac{2}{3}$ to twice as long as deep. Scales $28-29 \frac{4 \frac{1}{2}}{2 \frac{1}{2}}, 1$ between lateral line and ventral. Olive-green above, silvery below, with an ill-defined pink band along each side, beginning on the gillcover; a large blackish (in life dark greenish) patch on caudal peduncle and root of candal.

Total length 300 millim.

Several specimens from Niamkolo, Mtondwe Bay, and Lofu. Native names: Kolokolo and Kologo.

This is the fish previously recorded by me, from a single badly preserved specimen, as A. macrolepidotus C. \& V. But that species, of which I have examined over 100 examples from the Nile and from West Africa, has never more than 26 scales in the lateral line. A. batesii Blgr., from South Cameroon, agrees with the Tanganyikan species in the number of scales in the lateral line as well as in the number of anal rays, but there are two series of scales between the lateral line and the root of the ventral fin, the head is shorter in the adult, and the caudal peduncle is shorter, as in A. macrolepidotus. A. grandisquamis Blgr., from the Congo, and A. brevis Blgr., from Guinea, are other close allies of the Tanganyikan form, but both have a shorter head and a shorter caudal peduncle, and the first has 24 to 27 scales in the lateral line and 13 or 14 anal rays, the second 21 to 23 scales in the lateral line and 16 to 18 anal rays.

9. Citharinus gibbosus Blgr.

Niamkolo. Native name: Imbaza.

Dr. Cunnington measured a large specimen, which had been speared by the natives; its total length was 540 millim.

\section{Y P R I N I D A}

\section{Labeo cylindricus Peters.}

Two specimens, both with 10 branched rays in the dorsal fin, from Utinta. Native name: Bimanda.

Grows, according to Dr. Cunnington, to a length of 360 millim.

"Dark olive-green to almost black above, lighter below, with the belly greyish; scales with darker outlines ; all fins dark greenish black, darker between the rays."

L. cylindricus, which is very nearly related to the Nilotic $L$. forskalii, has a wide distribution in East Africa, from Abyssinia to the Zambesi. 
In my first Report I had recorded a Labeo from Lake Tanganyika, on the evidence of a sketch made by Mr. Moore; but as no specimen had been preserved, the species could not be determined.

11. Varicorhinds Tanganice Blgr.

Two specimens from Niamkolo. Native name: Imbara.

Dr. Cunnington measured a specimen 463 millim. long. "Greenish brown above; paired fins and anal with a pinkish tinge."

This is the fish described by me as Capoëta tanganica. I have since had occasion to show that Capoëta is a synonym of Varicorhinus of Rüppell, which has priority.

12. BARBUS SERRIFER Blgr.

Kituta, in a swamp. Native name: Palala.

"Olive-green above, shading to silver below; a red spot on gill-cover immediately behind eye ; blue-black spot at root of candal ; dorsal and caudal fins with distal third orange ; paired fins and anal yellowish."

13. BarbUS tropidolepis Blgr.

Niamkolo, Mbete, and Uvira. Native names: Kaluka Matanda, Kitumbi Mbalaga, and Birigi.

Dr. Cunnington notes that this fish grows to a length of 500 millim., and is often taken in rivers ${ }^{1}$. The colour in fresh specimens is olive above, shading off to silvery or to light brownish-grey and silvery; paired fins and anal yellowish; the largest specimen preserved (measuring 290 millim.) had the raised lines on the body of a lighter olive and a red blotch at the tip of the spine of the dorsal fin. A smaller specimen (195 millim.) has a short anterior barbel on one side only.

14. Barilius MOorit Blgr.

Sumbu. Native name: Kiriabakawba.

The largest specimen measures 160 millim., and has 11 very distinct vertical dark bars on the side.

15. Neobola minuta, sp. n. (Plate XXXII. fig. 1.)

Depth of body 6 times in the total length, length of head 5 times. Snout pointed, not projecting beyond the mouth, shorter than the eye, which is $3 \frac{1}{3}$ times in length of head and equals interorbital width; mouth extending to below anterior border of eye; suborbital bones covering greater part of cheek. Dorsal II 7, originating further back than anal, at equal distance from head and from root of caudal, longest ray about

* Cf. M. Questiaux's notes on the habits of the Mbiriki, in Boulenger, Poiss. Bass. Congo, p. 228. 
$\frac{1}{2}$ length of head. Anal II 18. Pectoral acutely pointed, as long as head, reaching root of ventral. Caudal deeply forked. Caudal peduncle twice as long as deep. Scales $37 \frac{7 \frac{1}{1}}{1 \frac{1}{2}}, 1$ between lateral line and root of ventral, 12 round caudal peduncle. Silvery, olive in the upper third.

Total length 26 millim. This, according to Dr. Cunnington, is the full size of the fish.

Several specimens were taken at Mbete, in shallow water, by means of a piece of calico held by two men. Native name: Salala.

The genus Neobola Vinciguerra is intermediate between Barilius Ham.-Buch. and Chelcthiops Blgr., differing from the former in the more posterior position of the dorsal fin, from the latter in the absence of a ventral keel and in the wider separation of the pectoral fins. Two species were known: N. bottegi Vincig., from Lake Rudolf, Gallaland, and Somaliland, and $N$. argentea Pellegr., from Lake Victoria.

The three species may be distinguished by means of the following characters :-

Anal 17-19, its origin corresponding to that of dorsal ; lateral line 40-45; mouth extending to beyond vertical of anterior border of eye . . . N. bottegi Vincig.

Anal 17-18, its origin corresponding to that of dorsal ; lateral line 48-52; mouth extending to below anterior border of eye . . . . . . . $N$. argentea Pellegr.

Anal 20, originating in advance of dorsal ; lateral line 37 ; mouth extending to below anterior border of eye. . . . . . . . . . . . . . N. minuta Blgr.

\section{S I L U R I D $A$.}

16. Clarias robecchit Vincig.

Niamkolo. Native name: Pongo or Kambali.

DiNotopterus, g. n.

Intermediate between Clarias and Heterobranchus. Dorsal fin divided into a rayed and an adipose portion, but the latter not supported by produced neural spines. Temple unprotected by bone.

17. Dinotopterus cunningtoni, sp. n. (Plate XXXI.)

Depth of body $7 \frac{1}{2}$ times in total length, length of head $3 \frac{2}{5}$ times. Head extremely flattened, once and $\frac{1}{3}$ as long as broad, its upper surface covered with very thin skin and rugose with striæ radiating from the occipital region; frontal fontanelle large, twice and $\frac{1}{2}$ as long as broad, $\frac{1}{4}$ length of head; occipital fontanelle very small; a rather long and narrow occipital process ; snout broad, truncate, not projecting beyond 
the mouth ; eye small, 3 times in length of snout, $7 \frac{1}{2}$ times in interorbital width ; nasal barbel $\frac{3}{5}$ length of head; maxillary barbel a little longer than head, reaching posterior third of pectoral; outer mandibular barbels once and $\frac{1}{2}$ as long as inner and nearly as long as head. Jaws with bands of minute villiform teeth; similar teeth form a rather broader crescentic band on the vomer. Gill-rakers very long and slender, closely set, about 110 on anterior arch. Dorsal with 53 rays, the posterior of which are the longest and measure about $\frac{1}{4}$ length of head; distance between first dorsal ray and occipital process $\frac{1}{3}$ length of head; adipose dorsal low and short, in contact with caudal. Anal with 43 rays, separated from the root of the caudal by a space equal to twice diameter of eye. Pectoral $\frac{1}{2}$ length of head; spine rather weak, not serrated, a little more than half length of fin. Ventral equally distant from end of snout and from root of caudal. Caudal rounded. Dark brown, almost black above, pinkish white beneath.

This remarkable fish is described from a single specimen, 500 millim. long, caught at Mpala in a floating basket-trap. Native name: Singa. Dr. Cunnington saw larger specimens, measuring 1020 and 1290 millim. A young specimen, 90 millim. long, was taken in a native trap at Mbete and is here figured (Plate XXXI. fig. $d$ ). The head is less depressed and the eyes are proportionally larger than in the adult; the ventrals are a little nearer the end of the snout than the root of the caudal.

This fish, although until now unknown to zoologists, has been alluded to by Burton ('The Lake Regions of Central Africa,' ii. p. 67) and by Stanley ('How I found Livingstone,' p. 530). The latter says: "The Silurus called by the Wajiji Singa, which grows, according to native report, to four and even six feet in length. The one I sketched was $38 \frac{1}{2}$ inches long, and weighed $10 \frac{3}{4}$ lbs., but was considered to be a small one. It is an extremely flat fish, of a dark brown colour on the back, and light brown, inclined to whiteness, on the belly." Coode Hore ("Tanganyika,' p. 150) also alludes to it as "the oily Singa (Silurus) of six feet in length." Cameron, on the other hand ("Across Africa,' i. p. 270), applies the name Singa to Protopterus: "In the afternoon I shot a large Lepidosiren, called by the natives Singa; but it was so loathsome to look at that no one would touch it, and the people declared it was poisonous."

\section{Chrysichthys BRachynema Blgr.}

A single specimen from Niamkolo. Native name: Mondi or Nvulu.

19. Cerrsichthys slanenna, sp. n. (Plate XXXII. fig. 2.)

Depth of body $5 \frac{1}{2}$ to 6 times in total length, length of head $4 \frac{1}{2}$ times. Head moderately depressed, once and $\frac{2}{5}$ to once and $\frac{1}{2}$ as long as broad, smooth above; snout rounded, projecting a little beyond the lower jaw, $\frac{1}{3}$ length of head, about $\frac{2}{3}$ width of mouth; eye 4 to $4 \frac{1}{2}$ times in length of head, once to once and $\frac{1}{3}$ in interorbital width; nasal barbel very thin, $\frac{1}{3}$ diameter of eye; maxillary barbel 
once and $\frac{1}{5}$ to once and $\frac{1}{3}$ length of head; outer mandibular barbel nearly twice as long as inner and half length of head; vomero-pterygoid teeth forming a long and narrow crescentic band; occipital process narrow, narrowly separated from the small interneural shield. Dorsal I 6 , nearly twice as distant from the root of the caudal as from the end of the snout; spine serrated behind, $\frac{1}{2}$ length of head; longest soft rays $\frac{3}{5}$ to $\frac{2}{3}$ length of head. Adipose dorsal small, 2 to 3 times as long as deep its base 3 to 4 times in its distance from the rayed dorsal. Anal IV 10. Pectoral spine about $\frac{3}{5}$ length of head, feebly serrated on outer side, more strongly on inner side. Ventral not reaching anal. Caudal deeply forked, with pointed lobes, outer rays 3 to $3 \frac{1}{2}$ times as long as the median. Caudal peduncle twice as long as deep. Colour in life olive above, shading to light grey and silver below; anterior edge of dorsal fin red, the tip black; maxillary barbels and ventral and caudal fins pinkish.

Total length 220 millim. Said not to grow larger.

Two specimens from Niamkolo and one from Mbete. Native name: Sianenna.

A very distinct species, to be placed near $C$. furcatus Gthr.

Phyllonemos, g. n.

Allied to Chrysichthys Blkr., but without nasal barbels and with the maxillary barbel fringed on both sides by a leaf-like membrane in its distal part; only vomerine teeth on the palate.

20. Phyllonemus typus, sp. n. (Plate XXXII. fig. 3.)

Depth of body $5 \frac{1}{2}$ times in total length, length of head $3 \frac{1}{2}$ times. Head smooth, once and $\frac{1}{2}$ as long as broad; occipital process very short, widely separated from the dorsal; snout flat, broadly rounded, subtruncate, projecting very slightly beyond the month; eye $\frac{1}{4}$ length of head, equal to interorbital width; maxillary barbel once and $\frac{2}{3}$ as long as head, extending beyond extremity of pectoral; outer mandibular barbels as long as head, twice as long as inner; vomerine teeth in a short transverse series. Dorsal I 6, a little nearer end of snout than root of caudal; spine short and feeble; longest rays $\frac{2}{3}$ length of head. Anal 12, opposed to adipose dorsal, which is about $\frac{2}{3}$ as long as its distance from the rayed dorsal. Pectoral spine $\frac{1}{2}$ length of head, strongly serrated on its inner border. Ventral inserted a little behind vertical of dorsal, not reaching anal. Caudal peduncle a little longer than deep. Caudal deeply notched. Brown above, white below; maxillary barbels blackish at the end; dorsal dark brown, adipose dark brown, white behind; caudal brown, each lobe tipped with white; anal white, dark brown at the base; ventrals white.

Total length 73 millim.

A single specimen from Niamkolo. Native name: Kapando. 


\section{Auchenoglanis occidentalis, var. tanganicanus. (Plate XXXiII.)}

Depth of body 4 to $\frac{1}{2}$ times in total length, length of head $: 3$ times. Head once and $\frac{1}{2}$ as long as broad, coarsely granulate above; snont pointed, about $\frac{3}{5}$ length of head; diameter of eye 7 to 9 times in length of head, 2 to $2 \frac{2}{3}$ times in interorbital width, which equals $\frac{1}{2}$ to $\frac{3}{5}$ length of snout; width of mouth about half that of head; lips thick, papillose; maxillary barbel about $\frac{2}{3}$ length of head, extending to posterior border of eye ; outer mandibular barbel as long as or but slightly longer than maxillary, inner mandibular $\frac{1}{4}$ to $\frac{1}{3}$ length of head; præmaxillary teeth forming tro small groups, which are longer than broad; mandibular teeth forming a band interrupted in the middle; occipital process broader than long, in contact with the large interneural shield. Humeral process small, acutely pointed. Dorsal I 7 ; spine rugose in front, not quite half length of head. Adipnse fin $3 \frac{1}{2}$ to $5 \frac{1}{2}$ times as loug as deep, narrowly separated from the rayed dorsal and from the caudal. Anal IV 8. Pectoral spine as long as dorsal, feebly serrated in front, strongly behind. Ventral not reaching anal. Caudal rounded or slightly notched. Olive or brownish grey above, with more or less distinct round darker spots, uniform white beneath; dorsal and caudal fins with numerous round dark spots.

Total length 350 millim.

I have previously recorded this species under the name of Auchenoglanis biscutatus. But the Tanganyikan specimens differ in the longer snout and the narrower interorbital space. They are hardly distinguishable from $A$. occidentalis $\mathrm{C}$. \& V., which inhabits the Nile, the river's of West Africa, and the Congo, and has also been confounded with A. biscutatus. The above-given description is taken from two specimens from Kalambo and one from the middle of the lake (Moore Collection) and from one from Mtondwe Bay (Cunnington Coll.). Native name: Poloko or Kavungwe.

\section{Synodontis multipunctatus Blgr.}

Niamkolo. Native name: Kamwengwe.

23. Synodontis melanostictus, sp. n. (Plate XXXIV.)

Body feebly compressed, its depth nearly equal to length of head and 4 times in total length. Head as long as broad, strongly granulate abore, the rugosities extending on the snout; frontal fontanelle narrow; snout rounded, slightly longer than postocular part of head; eye supero-lateral, nearly 6 times in length of head, twice and $\frac{1}{2}$ interorbital width; occipito-nuchal shield obtusely tectiform; mouth with moderately developed lips; maxillary barbel once and $\frac{1}{4}$ as long as head, without fringe or border; mandibular barbels with long simple barbs, the outer nearly as long as the maxillary; præmaxillary teeth forming a broad band, about 15 irregular transverse series; movable mandibular teeth about 30 , the longest $\frac{2}{5}$ diameter of eye. Gill-opening not extending below base of pectoral. Humeral process acutely pointed, without vOL. XVII.-PART VI. No. 3.-October, 1906. 
keel, granulate above, striated below, not extending beyond vertical of occipito-nuchal shield. Skin slightly villose on the sides of the body. Dorsal I 7 ; spine strong, curved, nearly as long as head, striated, smooth in front, with a few very feeble and indistinct serræ behind; a filament terminates the spine. Adipose dorsal 4 times as long as deep, twice and $\frac{1}{2}$ as long as its distance from the rayed dorsal. Anal IV 7. Pectoral spine striated and strongly serrated on both sides, nearly as long as head. Ventral not reaching anal. Caudal deeply forked, upper lobe longer. Grey above, white beneath, closely dotted with black on the body as well as on the fins.

Total length 260 millim. Grows to 520 millim. according to Dr. Cunnington.

A single specimen from Lofu. Native name: Kiyegeyege.

Allied to $S$. multipunctatus Blgr., zambesensis Peters, and punctulatus Gthr. Distinguished by the almost total absence of serration on the back of the dorsal fin-spine, the presence of strong serræ on the onter border of the pectoral spine, and the villosities on the body. The eye is much smaller than in S. multipunctatus.

This species is also nearly related to $S$. schall Bl. Schn., in which the upper surface of the snout is smooth and the outer edge of the pectoral spine more feebly serrated.

24. Malopterurus electricts Gm.

Niamkolo. Native name: Kunta.

CYPRINODONTID

25. Haplochilus pumilus, sp. n. (Plate XXXII. fig. 4.)

Depth of body $3 \frac{2}{3}$ to $4 \frac{1}{2}$ times in total length, length of head $3 \frac{1}{2}$ to 4 times. Upper surface of bead flat; snout shorter than the eye, the diameter of which is 3 times in length of head; lower jaw projecting beyond upper ; interorbital space $\frac{2}{5}$ length of head. Dorsal 10-11, originating nearer to root of caudal than to occiput; posterior rays longest, $\frac{1}{2}$ to $\frac{2}{3}$ length of head. Anal 14-15, originating at equal distance from eye and from root of caudal; posterior rays longest, about as long as dorsals. Pectoral $\frac{2}{3}$ length of head, reaching beyond base of ventral. Caudal rounded, nearly as long as head. Caudal peduncle once and $\frac{1}{3}$ as long as deep. Scales with the concentric striæ very indistinct, 27 to 29 in a longitudinal series, 7 in a transverse series. Yellowish, more brownish on the back, where the scales have darker outlines; fins purplish, without any markings.

'Total length 34 millim.

Three specimens, taken shore-wading at Kituta. Native name: Msipa.-The same species has been obtained in Lake Victoria by Mr. E. Degen.

26. Haplochilus tanganicanus Blgr.

Several specimens from Niamkolo, Moliro, and Mpala. Native name: Mishia.

Grows to 135 millim. Dorsal and anal fins striated with dark and light lines. 
SERRA NIDE.

\section{Lates Microlepis Blgr. (Plate XXXV. fig. 2.)}

Several specimens, measuring from 60 to 410 millim., from Niamkolo aud Kituta. Native name: Pamba or Sangala.

Dr. Cunuington has taken a photograph of a specimen measuring $1.34 \mathrm{~m}$.

28. Lates angustifrons, sp. n. (Plate XXXV. fig. 1.)

Depth of body $3 \frac{1}{3}$ times in total length, length of head 3 times. Upper profile of head nearly straight; diameter of eye $4 \frac{1}{2}$ times in length of head, once and $\frac{1}{3}$ in length of snout; interorbital space narrow, only $\frac{1}{2}$ diameter of eye; lower jaw projecting; maxillary extending to below centre of eye, the width of its distal extremity $\frac{1}{2}$ diameter of eye; præ- and suborbitals finely serrated; cheeks, opercles, and occiput covered with small scales; præopercular border forming nearly a right angle, finely toothed on its rertical limb, with three widely separated spines on its lower limb, and with a very strong spine at the angle; two strong opercular spines. 4 or 5 strong spines on the clavicle. 14 gill-rakers on lower part of anterior arch. Dorsal VII, I 12 ; third spine very strong, longest, about $\frac{1}{2}$ length of head; longest soft rays $\frac{1}{3}$ length of head. Anal III 8 ; spines short, second and third equal. Pectoral not quite $\frac{1}{2}$ length of head. Caudal rounded. Caudal peduncle once and $\frac{2}{3}$ as long as deep. Scales $125 \frac{14}{38}$. Dr. Cunnington describes the coloration as of a yellowish tinge all over, darkish grey above, shading to almost white below; middle region of body faintly mottled with darker grey; ventral fins yellowish.

Total length 265 millim.

A single specimen from Niamkolo. Native name: Pamba ekundu (Red Pamba).

This species, although very closely related to the preceding, is easily distinguished from it by its much narrower interorbital region ${ }^{I}$ and by the rounded caudal. According to Dr. Cunnington, the natives regard this fish as distinct in kind from L. microlepis, and they say it does not grow so large, the specimen here described being regarded by them as of the full size.

\section{I C H L I D $A$.}

29. Lamprologus brevianalis, sp. n. (Plate XXXVI. fig. 1.)

Depth of body $3 \frac{2}{3}$ times in total length, length of head 3 times. Snout pointed, a little longer than the eye, the diameter of which is contained $3 \frac{1}{2}$ times in length of head and equals interorbital width; maxillary extending to below anterior border

1 In the young $L$. microlepis the interorbital width equals at least $\frac{3}{5}$ the diameter of the eye, and it equals $\frac{3}{4}$ in a specimen nearly equal in size to the type of $L$. angustifrons (total length 245 millim.). An upper view of the head of this specimen is given on Pl. XXXV. fig. 2, for comparison. In a specimen $450 \mathrm{millim}$. long the interorbital width equals once and $\frac{1}{2}$ the diameter of the eye.

$4 \mathrm{E} 2$ 
of eye; 8 rather large canine teeth in front of the upper jaw and 4 in the lower, followed by a moderately broad band of minute, villiform teeth; lateral teeth small; cheek naked, operculum scaly; pits of sensory canals very large. Gill-rakers short, 9 on lower part of anterior arch. Dorsal XVIII-XIX 11, spines subequal from the eighth, $\frac{2}{5}$ length of head; longest soft ray $\frac{3}{5}$ length of head. Anal IV 7, fourth spine as long as longest dorsals. Pectoral rounded, $\frac{2}{3}$ length of head. Ventral reaching origin of anal. Caudal rounded. Caudal peduncle slightly longer than deep. Scales $40-43 \frac{5-6}{12}$; lateral lines $\frac{23-29}{9-15}$. Brown, somewhat lighter beneath, with darker and lighter longitudinal streaks on the sides and five broad dark transverse bands; vertical fins with numerous round whitish spots.

Total length 83 millim.

A single specimen from Niamkolo. Native name: Sietela. A young specimen was obtained in Komba Bay.

Very closely allied to L. tetracanthus Blgr., with which it agrees in the short anal fin with only four spines. Distinguished by the larger mouth extending to below the anterior border of the eye, and by the absence of a whitish marginal band on the dorsal fin.

30. Lamprologus elongatus Blgr.

This species, which was established on young specimens, proves to be the giant of the genus, exceeding L. lemairii in size. Three large specimens were brought home by Dr. Cunnington.

1. Niamkolo, off Mtondwe Island. Native name : Kibua. 'Total length 325 millim. D. XVIII 11 ; A. V 9 ; Sq. $90 \frac{11}{25}$; L. $1 . \frac{45}{26}$.

2. Sumbu. Total length 120 millim. D. XVII 10; A. V 8; Sq. $85 \frac{11}{25}$; L. 1. $\frac{47}{24}$.

3. Niamkolo Bay, taken from an empty Neothauma shell, dredged in a few fathoms. Total length 63 millim. D. XVIII 10; A. VI 8 ; Sq. $92 \frac{11}{27}$; L. $1 . \frac{36}{15}$.

The cheek, which is naked in the young, is much deeper ( 3 times diameter of eye) and covered with very small scales in the adult. The depth of the body is contained from $3 \frac{2}{3}$ to 4 times in the total length, the length of the head $2 \frac{3}{4}$ to 3 times. Diameter of eye, in the adult, 8 times in length of head, 3 times in length of snout, once and $\frac{1}{2}$ in interorbital width; the band of minute teeth behind the canines is much broader than in the young, and the longest rays of the dorsal and anal fins measure nearly $\frac{2}{3}$ the length of the head.

Dr. Cunnington describes the adult, when fresh, as black with white mottling. The vertical fins are dark brown, with round light spots.

Dr. Cunnington has noted that the fish readily takes artificial spinning-bait. 
31. Lamprologus cunningtoni, sp. n. (Plate XXXVI. fig. 2.)

Depth of body $3 \frac{3}{4}$ to $4 \frac{1}{4}$ times in total length, length of head $3 \frac{1}{3}$ times. Snout obtusely pointed, twice as long as eye, the diameter of which is contained 5 times in length of head, and once and $\frac{1}{4}$ in interorbital width; maxillary not extending quite to below anterior border of eye; 6 large canines in front of upper jaw, 4 in front of lower, followed by a rather broad band of minute, villiform teeth; lateral teeth small; cheek naked, its depth once and $\frac{1}{2}$ diameter of eye; operculum with a few scales. Gill-rakers short, 8 on lower part of anterior arch. Dorsal XX 10-11, spines increasing in length to the last, which measures about $\frac{1}{3}$ length of head; soft dorsal acutely pointed behind, longest ray measuring $\frac{2}{3}$ length of head. Anal V 7, last spine longest, as long as last dorsal ray; the fin pointed like the dorsal. Pectoral rounded, $\frac{3}{5}$ length of head. Ventral reaching vent or a little beyond. Caudal rounded. Caudal peduncle once and $\frac{1}{3}$ as long as deep. Scales $85-87 \frac{8-10}{20-21}$; lateral lines $\frac{54-55}{26-35}$. Greyish brown above, white beneath; small light spots on the sides; very indistinct traces of nive or six dark bars across the back; vertical fins brown, with rather indistinct small roundish light spots. Young with 7 or 8 regular dark bars on the body.

Total length 190 millim.

'Two adult specimsens from Moliro, native name Msheshe; and two young from Mbete, native name Twinanzoli.

This species is allied to $L$. elongatus, but easily distinguished by the rounded caudal fin, the shorter and fewer gill-rakers ( 8 instead of 12), and the more numerous spines in the dorsal fin ( 20 instead of 17 or 18 ).

32. Lamprologus tretocephalus Blgr.

A single specimen from Kigoma. Native name: Ndubu. Total length 53 millim. D. XVII $10 ;$ A. V 6 ; Sc. $42 \frac{7}{15}$; L. 1. $\frac{29}{10}$. Snout not longer than eye; canine teeth very small; ventral fin reaching beyond origin of anal.

33. Lamprologus mondabu, sp. n. (Plate XXXVI. fig. 3.)

Depth of body $3 \frac{2}{3}$ times in total length, length of head 3 times. Snont pointed, once and $\frac{2}{3}$ to twice as long as eye, the diameter of which is contained $4 \frac{1}{2}$ to 5 times in length of head and equals or is slightly less than interorbital width; maxillary extending to halfway between verticals of nostril and eye ; 6 large canines in front of each jaw, followed by a rather broad band of minute, villiform teeth; lateral teeth small; cheek naked, its depth once and $\frac{1}{3}$ diameter of eye; operculum with a few scales. Gill-rakers very short, 7 or 8 on lower part of anterior arch. Dorsal XIX 9; spines increasing in length to the last, which measures $\frac{2}{5}$ length of head; soft dorsal acutely pointed behind, longest ray measuring $\frac{3}{4}$ length of head. Anal V 7, last spine longest, $\frac{1}{3}$ length of head; the fin pointed like the dorsal. Pectoral rounded, $\frac{2}{3}$ length of head. 
Ventral reaching origin of anal. Caudal slightly emarginate. Caudal peduncle as long as deep. Scales $42-46 \frac{7-8}{13-14}$; lateral lines $\frac{25-27}{9-14}$. The coloration, in fresh speci. mens, as noted by Dr. Cunnington, varies from grey to olive, rather lighter below, but very uniform; dorsal edged with yellow, bluish in its upper portion, with yellow spots; upper half of caudal minutely spotted with yellow, lower half darker.

Total length 105 millim.

Two specimens. Native name: Mondabu.

Allied to L. modestus. Distinguished by the slightly emarginate caudal fin and the shorter mouth.

34. Lamprologus Modestus Blgr.

A young specimen from Komba Bay.

D. XX 8 ; A. VI 6 ; Sc. $36 \frac{4}{13}$; L. $1 \frac{19}{3}$. Yellowish, with 7 brown lines across the back.

35. Lamprologus multifasciatus, sp. $\mathrm{n}$. (Plate XXXV. fig. 3.)

Depth of body $3 \frac{1}{4}$ to $3 \frac{1}{2}$ times in total length, length of head $2 \frac{3}{4}$ to 3 times. Snout obtusely pointed, as long as the eye, the diameter of which is contained $3 \frac{1}{3}$ times in length of head and equals interorbital width; maxillary extending to below anterior border of eye, or a little beyond; 8 canine teeth in front of each jaw, outer very large, followed by a narrow band of villiform teeth; lateral teeth small; cheek naked, operculum scaly. Gill-rakers moderately long, 8 on Jower part of anterior arch. Dorsal XVII-XVIII 8-9, spines subequal from the eighth or ninth, about $\frac{2}{5}$ length of head; longest soft ray $\frac{1}{2}$ length of head. Anal VI-VII 6, last spine slightly longer than longest dorsal. Pectoral rounded, $\frac{3}{5}$ length of head. Ventral nearly reaching origin of anal. Caudal rounded. Caudal peduncle as long as deep. Scales 35-38 $\frac{3-4}{10-11}$; upper lateral line short, 8-15, lower absent. Pale brown above, white beneath, with 16 or 17 very regular dark brown bars, the last 3 or 4 of which are on the caudal fin; dorsal fin with oblique dark brown bars.

Total length 34 millim.

Five specimens from Niamkolo Bay, dredged among shells in about 12 fathoms.

This little fish is easily distinguished from all its congeners by its elegant markings and by the total absence of the lower lateral line.

36. Lamprologus lemairit Blgr.

Eight specimens from Niamkolo, measuring 102 to 220 millim. Native names: Kibua, Miseke or Moseke, Sietela.

Seven specimens have 19 spines and 7 soft rays in the dorsal fin, one has 18 spines and 8 soft rays; in the largest specimen the dorsal spines increase in length to the 
last, which measures half the length of the head, and the pectoral fin measures twothirds the length of the head. The anal spines number constantly 8 ; one specimen has 6 soft anal rays, the others having 5 . The adult specimen is of a uniform dark brown; the other specimens, according to the collector's notes, were grey-brown or olive above, shading to white beneath, the scales of the upper parts dark-edged; the dark bars on the body less distinct than in the type specimen; the dorsal fin is tipped with black, the pectorals are olive and the ventrals black.

\section{Lanprologus HecQUi Blgr.}

Two specimens from Niamkolo Bay, taken in an empty Neothauma shell, and three from Mtondwe Bay. 'Total length 45-60 millim. Regarded by the native fishermen as adult, and called by them Kitota, Nyonga, and Mpama.

Depth of body $3 \frac{1}{2}$ to $3 \frac{2}{3}$ times in total length. Dorsal XVIII-XIX 8-9; anal VI-VII 7-8. Scales 52-56 $\frac{5-7}{15-17}$; lat. 1. $\frac{25-36}{4-10}$. Gill-rakers rather long and slender, 12 to 15 on lower part of anterior arch. Grey above, lighter below, with 8 or 9 dark vertical bars on each side, or large blotches alternating with narrow bars; a more or less distinct dark round spot at the root of the caudal fin; vertical fins with dark bars; dorsal fin and upper part of caudal with a pale border faintly edged with black, as in L. callipterus.

38. Lamprologus callipterus, sp. n. (Plate XXXVI. fig. 4.)

Depth of body equal to length of head, $3 \frac{1}{3}$ to $3 \frac{1}{2}$ times in total length. Snout obtusely pointed, once and $\frac{1}{2}$ as long as eye, the diameter of which is contained 4 times in length of head and hardly equals interorbital width; maxillary extending to below anterior border of eye; 6 or 8 large canines in front of each jaw, followed by a moderately broad band of minute, villiform teeth; lateral teeth small ; cheek entirely naked or almost so; operculum with large scales. Gill-rakers rather long, 10 to 12 on lower part of anterior arch. Dorsal XVIII-XIX 9, spines increasing in length to the last, which measures nearly $\frac{1}{2}$ length of head; soft dorsal acutely pointed, longest ray $\frac{2}{3}$ to $\frac{3}{4}$ length of head. Anal VIII $7-8$, last spine nearly as long as last spine of dorsal; the fin pointed like the dorsal. Pectoral rounded, about $\frac{2}{3}$ length of head. Ventral extending to origin of anal, or beyond. Caudal rounded. Caudal peduncle once and $\frac{1}{3}$ to once and $\frac{1}{2}$ as long as deep. Scales $38-40 \frac{4}{10-11}$; lateral lines $\frac{24-25}{10-13}$. Brown or olive above, paler or whitish below, the scales edged with darker; dorsal fin with a yellow border finely edged with blackish, this border continued on the upper third of the caudal; vertical fins with numerous small round whitish spots.

Three specimens, measuring from 90 to 125 millim. The largest is from Mpala, the two others from Niamkolo. Native name: Zagezi and Miseke or Moseke. 
Allied to $L$. lemairii and $L$. hecqui. Distinguished from the former by the longer gill-rakers, the broader interorbital space, fewer scales in a vertical series, and more numerous soft rays in the anal fin; from the latter by larger scales and 8 anal spines instead of 6 or 7 .

\section{Lamprologus reticulatus, sp. n. (Plate XXXV. fig. 4.)}

Depth of body 4 times in total length, length of head $3 \frac{1}{4}$ times. Snout pointed, as long as the eye, the diameter of which is contained $3 \frac{1}{4}$ times in length of head and equals interorbital width; maxillary extending to below anterior fourth of eye ; canines very small, followed by a narrow band of minute, villiform teeth; a few scales on the cheek; operculum with large scales. Gill-rakers short, 14 on lower part of anterior arch. Dorsal XIX 10, spines increasing in length to the last, which measures $\frac{1}{2}$ length of head; longest soft dorsal ray but slightly longer than longest spine. Anal VIII 8, last spine as long as last dorsal spine. Pectoral rounded, $\frac{3}{4}$ length of head. Ventral extending to origin of anal. Caudal truncate, slightly emarginate. Caudal peduncle once and $\frac{1}{2}$ as long as deep. Scales $39 \frac{\frac{t}{13}}{13}$; lateral lines $\frac{27}{14}$. Brown, the scales edged with darker, forming a reticulate pattern; dorsal and anal fins dark brown, with oblique rows of round whitish spots; caudal fin brown, with numerous, rather indistinct light spots at the base, and an oblique whitish streak in the upper corner.

Total length 62 millim.

A single specimen from Vua. Native name: Zagezi, like $L$. callipterts.

Distinguished from $L$. callipterus, the young of which it resembles in coloration, by the truncate caudal fin and the smaller teeth.

40. Lamprologus calliurus, sp. n. (Plate XXXV. fig. 5.)

Deptlı of body $2 \frac{3}{4}$ to 3 times in total length, length of head 3 times. Snout obtuse, a little shorter than the diameter of the eye, which is $\frac{1}{3}$ length of the head and a little greater than interorbital width; maxillary extending to below anterior fourth of eye ; outer canines strong, curved; a narrow band of minute, villiform teeth; cheek naked; operculum scaly. Gill-rakers long and slender, 14 to 16 on lower part of anterior arch. Dorsal XVII-XVIII $\tau$; spines subequal from the eighth or ninth, measuring about $\frac{1}{2}$ length of head; soft rays a little longer. Anal VIII 6-8, last spine nearly as long as longest dorsal spines. Pectoral rounded, $\frac{2}{3}$ length of head. Ventral extending beyond origin of anal. Caudal truncate. Caudal peduncle a little deeper than long. Scales $35-36 \frac{3-4}{12-13}$; lateral lines $\frac{15-23}{3-10}$. Yellow, brownish on the back, with rather indistinct darker bars across the back and across the caudal fin; a sharply defined black opercular spot, edged with silvery in front.

Total length 50 millim. 
Three specimens, dredged among shells in about 30 fathoms at Tembwi.

Nearly allied to $L$. brevis. Differing in the truncate caudal and in the longer and more numerous gill-rakers.

\section{Lamprologus Brevis Blgr.}

This species was founded on a single specimen, 35 millim. long, obtained by Captain Hecq at Albertville. The Cunnington collection contains two specimens, measuring 45 and 38 millim. respectively, from Rumonge, which agree very closely with the type, but show variation in the fin-rays, viz.:-D. XVII-XVIII 7; A. VII-VIII 6. Depth of body equal to length of head, 3 times in total length. 30 to 35 scales in a longitudinal series; scales on nape very small. Uniform brown above, whitish beneath ; fins brown, without spots, dorsal tipped with black, ventrals black at the end; opercular black spot strongly marked.

42. LAMPROLOGUS COMPRESSICHPS Blgr.

A single young specimen from Niamkolo.

The number of species of Lamprologus now known from Lake Tanganyika amounts to 18 , the principal characters of which are tabulated on p. 562 .

43. Telmatochromis temporalis Blgr.

11 specimens from Kaboge, Mshale, Kituta, Mtondwe Bay, and Niamkolo Island. Native names: Mbulila, Fisia (young), and Kamfoto (young).

Dorsal XVIII-XX 7-10; Anal VI-VII 6- 7 ; Sq. 40-47 $\frac{4-6}{14-15} ;$ L. 1. $\frac{14-27}{3-16}$. Dr. Cunnington describes the adult as olive, with dark patches in dorsal region and irregular blotches on body and root of tail; the temporal band orange; dorsal fin spotted with yellow and white, and tipped with red; caudal and anal spotted with yellow and white. In the young the body may be crossed by dark bars; the temporal band is very distinct, and the bar at the base of the pectoral fin is edged with whitish behind.

44. Paratilapia frontosa, sp. n. (Plate XXXVII. fig. 1.)

Depth of body twice and $\frac{1}{2}$ in total length, length of head nearly 3 times. Forehead gibbose $^{1}$, the head at the interorbital region as deep as the body; snout twice and $\frac{1}{3}$ as long as the eye, the diameter of which is contained $5 \frac{1}{3}$ times in length of head and nearly twice in interorbital region; maxillary not extending to below anterior border of eye; 3 series of teeth in each jaw, outer large; 5 series of scales on the cheek; large scales on the operculum. Gill-rakers rather long, 13 on lower part of anterior arch. Dorsal XIX 8 ; spines increasing in length to the last, which measures a little

${ }^{1}$ Probably in adult males only.

VOL. XVII.-PART VI. No. 4.-October, 1906. 
Principal Characters of the Species of Lamprologus.

\begin{tabular}{|c|c|c|c|c|c|}
\hline & Dorsal. & Anal. & Scales. & $\begin{array}{l}\text { Gill- } \\
\text { rakers. }\end{array}$ & Caudal. \\
\hline L. brevianalis . .... & XVIII-XIX 11 & IV 7 & $40-43 \frac{5-6}{12}$ & 9 & Rounded. \\
\hline L. tetracanthus $\ldots$.. & $\mathrm{XX} 10$ & IV 7 & $41 \frac{8}{15}$ & 10 & Rounded. \\
\hline L. elongatus ...... & XVII-XVIII 10-11 & $\nabla-\nabla I 7-9$ & $85-95 \frac{10-11}{22-28}$ & 12 & Truncate. \\
\hline L. cunningtoni $\ldots$ & $\mathrm{XX} 10-11$ & $\nabla 7$ & $85-87 \frac{8-10}{20-21}$ & 8 & Rounded. \\
\hline L. tretocephalus . & XVI-XVII 10-11 & $\mathrm{V} 6$ & $37-42 \frac{7-8}{15}$ & 9 & Rounded. \\
\hline L. mondabu & XIX 9 & $\vee 7$ & $42-46 \frac{7-8}{13-14}$ & $7-8$ & Slightly emarginate. \\
\hline L. modestus....... & $\mathrm{XIX}-\mathrm{XX} 8-10$ & V-VI $6-7$ & $36-40 \frac{4-6}{12-14}$ & 7 & Truncate. \\
\hline L. multifasciatus ... & XVII-XVIII 8-9 & VI-VII 6 & $35-38 \frac{3-4}{10-11}$ & 8 & Rounded. \\
\hline L. lemairii ....... & XVIII-XIX 7-8 & VIII 5-6 & $40-48 \frac{8-11}{16-18}$ & $9-10$ & Rounded. \\
\hline L. hecqui. . . . & XVIII-XIX 8-9 & VI-PII 7-8 & $52-57 \frac{5-7}{15-17}$ & $12-16$ & Rounded. \\
\hline L. moorii $\ldots \ldots \ldots$ & XIX-XX 8-9 & VII-VIII 6-7 & $33-35 \frac{5-7}{11-12}$ & $9-10$ & Rounded. \\
\hline L. callipterus ...... & XVIII-XIX 9 & VIII 7-8 & $38-40 \frac{4}{10-11}$ & $10-12$ & Rounded. \\
\hline L. reticulatus ..... & XIX 10 & VIII 8 & $39 \frac{4}{13}$ & 14 & Truncate. \\
\hline L. calliurus. . & XVIII-XIX 8 & VIII $6-8$ & $35-36 \frac{3-4}{12-13}$ & $14-16$ & Truncate. \\
\hline L. brevis ... & XVII-XVIII 6-7 & VII-IX 5-6 & $33-35 \frac{3}{13}$ & 9 & Rounded. \\
\hline L. compressiceps.... & $\mathrm{XX}-\mathrm{XXI} 6$ & $\mathrm{X} 5$ & $32-33 \frac{5}{12}$ & 15 & Rounded. \\
\hline L. fasciatus $\quad \ldots$ & XIX 8 & $\times 6$ & $46 \frac{5}{10}$ & 12 & Rounded. \\
\hline L. furcifer ... & XIX-XXI $7-9$ & VI-VII 5-6 & $50-60 \frac{6-8}{16-20}$ & $14-16$ & Deeply notched. \\
\hline
\end{tabular}

less than $\frac{1}{3}$ length of head; soft dorsal much produced, longest ray nearly as long as head. Anal III 7, third spine as long as, but stronger than, last dorsal, soft rays like those of dorsal. Pectoral acutely pointed, as long as head, reaching origin of anal. Ventral produced into a long filament, extending beyond origin of anal. Caudal rounded. Caudal peduncle as long as deep. Scales $36 \frac{5}{20}$; lateral lines $\frac{23}{15}$. Brownish above, whitish beneath, with six broad dark cross-bands, the last two on the caudal peduncle; a dark brown opercular spot and a large dark brown spot at the base of the pectoral fin; fins without markings.

Total length 255 millim. 
A single specimen from Kigoma. Native name: $N d u b u$.

This species occupies an isolated position. The number of spinous rays in the dorsal fin exceeds that of any species previous?y described of the genus Paratilapia.

45. Paratilapia pfefferi Blgr.

Two specimens from Sumbu. Native name: Kilomo.

Dorsal XVI 9-10; Anal III 7-8; Scales 32-33 $\frac{3-4}{10}$; Lateral lines $\frac{22}{10-14}$. 3 or 4 series of scales on the cheek.

Dr. Cunnington has noted that the female nurses the embryos in her mouth. One of the specimens, measuring 72 millimetres, has a few large ova ( $2 \frac{1}{2}$ millim. in diameter) in the pharynx.

\section{Paratilapia ventralis Blgr.}

Two specimens from Sumbu. Native name: Lala.

Dr. Cunnington describes the coloration as follows:-Blackish all over, but with blues and greens showing in places; dorsal fin light blue-green, tipped with blackish; anal similar, but with broader band of black; ventrals black, bright yellow and bifurcate at the end.

\section{Paratilapia dewindti Blgr.}

One specimen from Sumbu and one from Lofu River. Native name: Kisangi.

Depth of body equal to length of head, twice and $\frac{3}{4}$ in total length. Lateral lines $\frac{30-34}{11-18}$. Described by Dr. Cunnington as dark olive above, silvery below, with five longitudinal stripes of violet alternating with stripes of yellowish; a black blotch on the gill-cover behind the eye; gular region yellowish; dorsal fin with brownish stripes and tipped with yellow; caudal with olive vertical bars; ventrals and anal blackish at the ends.

\section{Paratilapia furcifer Blgi.}

Two specimens from Niamkolo and two from Sumbu. Native names: Liukonko (plural Makonko) and Lala.

The largest specimen measures 135 millim., the types not exceeding 110 millim. In these large specimens the length of the eye equals that of the snout and the interorbital width and $\frac{1}{3}$ the length of the head. Dorsal XIII-XIV 12-14; Anal III 9; Scales $60-64 \frac{5-6}{18}$; Lateral lines $\frac{50-58}{23-33}$.

Dr. Cunnington describes the colour as olive above, lighter to silvery below, with bright iridescent blues and greens; gill-cover yellow; dorsal and anal fins light iridescent violet, with oblique stripes of yellow passing into dark stripes posteriorly, 
the rays tipped with black; caudal yellow, with dark dorsal and ventral margins; ventrals light bluish with some yellow stripes, the produced filaments tipped with yellow.

49. Paratilapia stenosoma Blgr.

A single specimen, measuring 240 millim., from Kaboge.

Dorsal XV 13; Anal III 14; Scales $69 \frac{6}{13}$; Lat. 1. $\frac{69}{36}$, the upper extending uninterrupted from above the operculum to the root of the caudal fin. 28 gill-rakers on lower part of anterior arch.

50. Bathybates Ferox Blgr.

Two specimens from Niamkolo and two from Kasakalawe. Native names: Lilembela (plural Malambela) and Molirdi.

These specimens measure 160 to 275 millim. and have the fin-formula: D. XIV 15, A. III 16-17. 14 or 15 gill-rakers on lower part of anterior arch. The length of the pectoral fin may not exceed $\frac{2}{3}$ that of the head.

\section{Bathybates fasciatus Blgr.}

A single specimen, measuring 335 millim., from Niamkolo. Native name: Mishipa. Dorsal XVI 17; Anal III 17; 19 gill-rakers on lower part of anterior arch ; Scales $150 \frac{11}{32}$; Lat. $1 . \frac{80}{48}$. Length of head $3 \frac{1}{4}$ times in total length. Caudal peduncle twice as long as deep. The black basal band on the dorsal fin is absent.

52. Bathybates minor, sp. n. (Plate XXXVIII. fig. 1.)

Depth of body $3 \frac{1}{2}$ to $3 \frac{2}{3}$ times in total length, length of head $2 \frac{3}{4}$ to 3 times. Snout with convex profile, slightly longer than the eye, the diameter of which is contained $3 \frac{1}{2}$ to $3 \frac{2}{3}$ times in length of head and slightly exceeds interocular width; maxillary extending to below anterior border of eye; teeth in 2 or 3 series in the upper jaw, in 2 in the lower; 5 series of small scales on the cheek. Gill-rakers rather short and thin, 12. on lower part of anterior arch. Dorsal XIII 15-16, deeply notched, the eighth to eleventh spines being only about half as long as the fifth and last, which are the longest and measure about $\frac{2}{7}$ length of head; longest soft rays $\frac{2}{5}$ to $\frac{1}{2}$ length of head. Anal III $16-17$, longest soft rays $\frac{2}{5}$ to $\frac{1}{2}$ length of head. Pectoral pointed, $\frac{2}{3}$ length of head. Ventral not reaching vent. Caudal forked. Caudal peduncle $1 \frac{1}{2}$ to $1 \frac{2}{3}$ times as long as deep. Scales small and very irregular, 90-95 $\frac{9-10}{27-30}$; lateral lines $\frac{63-71}{37-39}$. Brown above, silvery on the sides and below ; spinous dorsal black, white at the base; a black streak along the middle of the soft dorsal.

'Total length 160 millim.

Two specimens from Kituta and Lofu. Native names : Nswepa and Lulambi. Also 
some quite young specimens, 30 to 35 millim. long, from Mbete. Several specimens had previously been obtained by $\mathrm{Mr}$. Moore on the Usambara market; but they were badly preserved, and I took them to be the young of $B$. ferox.

Pellegrin has placed Bathybates in his division "Opisthospondyli" I. I can see no justification for this course, the vertebral column not differing notably from such forms as Paratilapia robusta and longiceps. Bathybates is more nearly related to Paratilapia than to any other genus, differing chiefly in the longer anal fin and in the dentition; this consists of an outer series of ankylosed teeth, behind which are one to three series of hinged depressible teeth. We are now acquainted with three species, the principal characters of which may be contrasted as follows :-

I. Spinous dorsal fin not notched, the posterior spines subequal; 3 or 4 series of teeth in the upper jaw, 3 in the lower.

D. XIV-XV 15-16; A. III 16-17; Sq. 78-100 $35-8$; ; 13-15 gill-rakers on lower part of anterior arch ; interocular width less than diameter of eye. B. ferox Blgr.

D. XVI 16-17; A. III 17-18; Sq. 140-150 $25-31$; $; 18-19$ gill-rakers on lower part of anterior arch; interocular width greater than diameter of eye . . . . . . . . . . . . . . . . . . . . . B. fasciatus Blgr.

II. Spinous dorsal notched, the last spine twice as long as the antepenultimate; 2 or 3 series of teeth in the npper jaw, 2 in the lower.

D. XIII 15-16; A. III 16-17; Sq. $90-95 \frac{9-10}{27-30} ; 12$ gill-rakers on lower part of anterior arch; interocular width slightly less than diamcter of eye . . . . . . . . . . . . . . . . . . . . . B. minor Blgr.

I may here add, as a correction to the original diagnosis of the genus, that wellpreserved specimens show the maxillary bone not to be exposed when the mouth is fully closed.

\section{Haplotaxodon, g. n.}

Mouth nearly vertical, directed upwards, with a single series of small, equal, conical teeth. Maxillary exposed at the end. Body elongate, strongly compressed, covered

1 So far as I am acquainted with the number of vertebræ in the African Cichlidæ, the following species only are to be referred to this disision :-

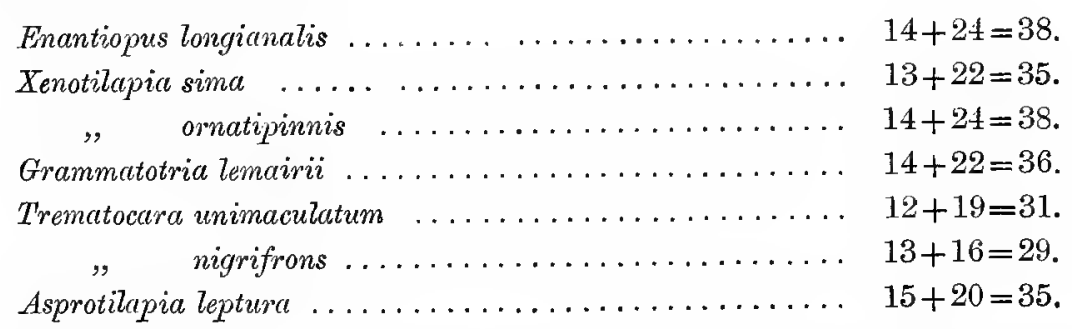

All generic forms restricted, according to the present state of our knowledge, to Lake Tanganyika. 
with small ctenoid scales; two lateral lines, the upper complete. Dorsal with 17 or 18 spines, anal with 3̊. Vertebræ $38(19+19)$.

The presence of a single series of teeth distinguishes this genus from Paratilapia, with which it is connected by $P$. stenosoma.

53. Haplotaxodon microlepis, sp. n. (Plate XXXVIII. fig. 2.)

Depth of body $3 \frac{1}{3}$ to $3 \frac{1}{2}$ times as long as deep, length of head $3 \frac{1}{2}$ to $3 \frac{2}{3}$ times. Snout much shorter than the eye, chin very prominent; eye very large, $2 \frac{3}{4}$ to 3 times in length of head (chin included), its diameter much greater than interocular width; maxillary not extending to below anterior border of eye; two series of scales on the cheek; opercle scaly. Gill-rakers long and slender, closely set, 18 to 20 on lower part of anterior arch. Dorsal XVII-XVIII 11-12; spines strong, equal in length from the 9 th or 10 th, $\frac{1}{2}$ length of head; longest soft rays about $\frac{2}{3}$ length of head. Anal III 9 ; spines very strong, 3rd longest, $\frac{1}{2}$ length of head. Pectoral acutely pointed, slightly shorter than head, not reaching origin of anal. Ventral produced into a filament extending a little beyond origin of anal. Caudal peduncle twice as long as deep. Caudal deeply notched. Scales $70-77 \frac{6}{23-24}$; lateral lines $\frac{65-77}{36-44} ; 4$ or 5 series of scales between the lateral lines in front. Olive or grey above, shading off to silvery white below; dorsal and caudal grey-brown, with yellowish-white large round spots; anal and ventrals white, tinged with yellow.

'Total length 210 millim.

One specimen from Niamkolo (native name Liukonko, plural Makonko), one from Kasawa, and one from Kasanga (native name Lukoko).

\section{Pelmatochromis polylepis Blgr. (Plate XXXVII. fig. 2.)}

Mtondwe Bay and Niamkolo, four specimens, measuring from 102 to 300 nnilim. Dr. Cunnington measured one of 435 millim. Dorsal XV 13-15; Anal III 8; gillrakers 12-14 on lower part of anterior arch; Scales 58-67 $\frac{7-8}{\frac{3}{16-19}}$; Lateral lines $\frac{30-33}{41-44}$. In the largest specimen the snout is once and two-thirds as Jong as the eye, which is 4 times in the length of the head. The smallest specimen (here figured) is remarkable in having the 3rd to 5th spines of the dorsal longest, half the length of the head. The coloration is described by Dr. Cunnington as greyish or brownish grey above, white below, with or without five or six inconspicuous vertical darker stripes on the body; the markings on the dorsal fin brown; patches of red at the angle of the jaws and at the roots of the paired fins; a red vertical stripe on the gill-cover; anterior rays of dorsal tipped with red.

According to Dr. Cunnington, the female carries eggs in her mouth.

Native names: Sange and Kanga. 
55. Pelmatochromis melatostjgma, sp. n. (Plate XXXIX. fig. 1.)

Depth of body $2 \frac{3}{4}$ to $3 \frac{1}{4}$ times in total length, length of head $2 \frac{2}{3}$ to $2 \frac{3}{4}$ times. Snout with more or less curved upper profile, as long as or a little shorter than the eye, which is $2 \frac{3}{4}$ to 3 times in length of head and exceeds interocular width; mouth extending to below anterior border of eye; teeth forming a narrow villiform band, some on the sides of the lower jaw strongly enlarged; two series of scales on the cheek. Gillrakers short, 10 to 12 on lower part of anterior arch. Dorsal XV-XVI 11-12; spines rather strong, equal in length from the sixth or seventh, $\frac{2}{5}$ to $\frac{1}{3}$ length of head; longest soft rays $\frac{1}{2}$ length of head. Anal III $6-7$; third spine a little shorter than longest dorsals. Pectoral acutely pointed, slightly shorter than head, reaching origin of anal. Ventral reaching origin of anal or beyond. Caudal peduncle once and $\frac{1}{2}$ as long as deep. Caudal deeply notched. Scales finely denticulate, 34-48 ${ }_{-11}^{3 \frac{3}{2}-4 \frac{1}{2}}$; lateral lines 30-35. Dark olive above, yellow on the sides, lighter to silvery below; more or less regular longitudinal series of small black spots on the back and sides; a blackish opercular spot; a reddish spot below the eye; dorsal fin yellow, tipped with blackish, with black spots, which may form oblique series, and an orange marginal band in front: pectoral yellow; gular region and ventral fins orange. In other specimens the black spots are absent and the dorsal and anal may be broadly edged with black.

The vertebræ number $34(16+18)$.

Total length 115 millim.

Two specimens from Uvira (native name Mariongo), one from Kaboge (same native name), five from Niamkolo (native name Malenda or Marenda), one from Lofu (same native name), and one from Kituta.

56. Pelmatochromis pleurospilus, sp. n. (Plate XXXIX. fig. 2.)

Depth of body $3 \frac{1}{2}$ times in total length, length of head $2 \frac{3}{4}$ to 3 times. Snout with curved upper profile, as long as the eye, which is 3 times in length of head and a little exceeds interocular width; mouth not extending quite to below anterior border of eye ; teeth forming a narrow villiform band; two series of scales on the cheek. Gill-rakers short, 11 or 12 on lower part of anterior arch. Dorsal XII-XIII 12-13; spines equal in length from the fifth, $\frac{1}{3}$ length of head, soft rays not longer. Anal III 7-8; third spine as long as longest dorsals. Pectoral acutely pointed, slightly shorter than head, reaching origin of anal. Ventral reaching origin of anal. Caudal peduncle twice and $\frac{1}{2}$ as long as deep. Caudal deeply notched. Scales finely denticulate, $32-35 \frac{2 \frac{1}{2}}{10}$; lateral lines $\frac{22-28}{8-14}$. Olive above, silvery white beneath; a black opercular spot, followed by a series of six black spots along the side of the body; the back of the male shot with red; dorsal with blackish or brownish spots, tipped with black; dorsal and anal edged with orange, more conspicuously in the male than in the female; pectoral 
yellow or orange; caudal with an orange band, with $\left(\sigma^{*}\right)$ or without $(q)$ white and grey markings.

Total length 75 millim.

Three specimens from Mpala and three from Tembwi. Native name: Sembe.

The females carry eggs in the mouth.

57. Pelmatochromis rhodostigma, sp. n. (Plate XXXIX. fig. 3.)

Depth of body $3 \frac{1}{2}$ times in total length, length of head 3 times. Snout with slightly curved upper profile, as long as the eye, which is 3 times in length of head and slightly exceeds interocular width; mouth extending to below anterior border of eye; teeth forming a narrow villiform band, some enlarged and curved on the side of the lower jaw; two series of scales on the cheek. Gill-rakers short, 10 on lower part of anterior arch. Dorsal XIII 13-14, spines equal from the fifth, about $\frac{2}{5}$ length of head, soft rays not longer. Anal III $7-8$, third spine as long as longest dorsals. Pectoral acutely pointed, as long as head, reaching origin of anal. Ventral reaching origin of anal. Caudal peduncle once and $\frac{1}{2}$ as long as deep. Candal deeply notched. Scales finely denticulate, $34-35 \frac{3 \frac{1}{2}}{11}$; lateral lines $\frac{23}{8}$. Olive above, silvery white below; longitudinal series of pink dots on the body; throat pink; dorsal streaked with pink; pectorals and ventrals pink; a pink band on each lobe of the caudal.

Total length 75 millim.

Two specimens from Mshale. Native name: Kasalu.

This species is closely allied to the preceding. It differs in the enlarged teeth on the sides of the lower jaw and in the number of scales in a transverse series.

58. Pelmatochromis auritus Blgr. (Plate XXXIX. fig. 4.)

Two adult specimens from the Kazzaga market, native name Kibombobombo; three young from Mshale, native name Kanyamitenga.

The coloration of the adult when fresh is described as light olive above, silvery below, with a good deal of yellow towards the tail; three or four longitudinal rows of iridescent bluish spots in the middle third of the body; dorsal and anal fins with white spots, the former tipped yellow and black; pectorals yellowish, ventrals white; caudal with white spots and yellow bars, and tipped blackish. Young specimens, measuring 65-70 millim. (Plate XXXIX. fig. 4), have very distinct silvery oblique stripes on the body; the dorsal and anal fins are uniform brown. The caudal fin of these young specimens is truncate, not emarginate.

I agree with Pellegrin in referring this species, originally described as a Paratilapia, to Pelmatochromis.

59. Ectodus descampsi Blgr.

Three specimens from Sumbu. Native name: Kasha.

Total length 80 millim. In his notes Dr. Cunnington mentions that these are 
apparently full-sized females, with eggs in the mouth. A few eggs, measuring 4 millim. in diameter, are still in the pharynx.

Dorsal XIII 5; Anal III 10-11; Scales $37-38 \frac{3}{11}$; Lateral lines $\frac{27-31}{18-19} ; 17$ gill-rakers on lower part of anterior arch. Vertebræ $36(17+19)$.

This genus was established for two species, $E$. descampsi and E. melanogenys. The second differs, however, in having the inner rays of the ventral fin longest and the caudal vertebræ much more numerous than the præcaudals, characters which it shares with Xenotilapia; whilst in the first the outer soft rays of the ventral are, as usual, the longest, and the caudal vertebræ do not differ much in number from the præcaudals. I therefore propose a new genus, Enantiopus, for $E$. melanogenys and its near ally E. longianalis.

60. Enantiopus melanogenys Blgr.

Two specimens, 70-75 millim. long, from Kigoma. Native name: Mulunda.

Dorsal XIV 15; Anal III 13; Scales $40 \frac{3}{9-10}$; Lateral lines $\frac{22-27}{11-12} ; 11$ or 12 gill-rakers on lower part of anterior arch.

61. Enantiopus longianalis Blgr.

Three specimens from Mbete, native name Kieta; two from Moliro, native name Karonda; one from Rumonge and one from Sumbua. The last two, females, carrying eggs in the pharynx. These specimens measure 100 to 135 millim.

Dorsal XIV 16-17; Anal III 16-17; Scales $40-42 \frac{3}{9}$; Lateral lines $\frac{25-29}{10-20}$; 12 or 13 gill-rakers on lower part of anterior arch.

The number of rays in the anal fin is quite sufficient for separating this species from the preceding.

\section{Xenotilapia sima Blgr.}

Two specimens, measuring 130 millim., from Niamkolo. Native name: Mtununu.

Dorsal XIV 14; Anal III 11; Scales $37-38 \frac{3}{10}$; Lateral lines $\frac{25-26}{24-28} ; 10$ or 11 gillrakers on lower part of anterior arch. Dr. Cunnington describes the colour as delicate brownish above, silvery below; head dark above.

\section{Grammatotria lemairit Blgr.}

Two specimens from Niamkolo, native name Mendi, and one from Kasawa, native name Lungi. These specimens measure from 130 to 210 millim.

Dorsal XV 14-15 ; Anal III-IV 10-11; Scales 52-55 $\frac{4-5}{12-14}$; Lateral lines $\frac{4 \mathrm{I}-43}{24-26}$; 10 or 11 gill-rakers on lower part of anterior arch. Dr. Cunnington describes the colour as uniform grey or delicate brownish above, silvery below; opalescent blues below voL. XVII.-PART VI. No. 5.-October, 1906. 
the eye and on the gill-cover; dorsal fin fringed with black. The vertebræ number $36(14+22)$.

64. Trematocara nigrifrons, sp. n. (Plate XLI. fig. 1.)

Depth of body $3 \frac{1}{2}$ times in total length, length of head 3 times. Snout with curved upper profile, a little shorter than the eye, which is twice and $\frac{3}{4}$ in length of head and a little exceeds interorbital width; mouth extending to below anterior fourth of eye; head naked, with large cavities as in the other species of the gemus. Gillrakers long and slender, closely set, 20 or 21 on lower part of anterior arch. Dorsal X 11-12; spines feeble, increasing in length to the last, which measures $\frac{2}{5}$ length of head; last soft rays a little shorter. Anal III 10 ; third spine as long as longest dorsal. Pectoral acutely pointed, a little longer than the head. Ventral not reaching origin of anal. Caudal with deep crescentic notch. Caudal peduncle once and $\frac{1}{2}$ as long as deep. Scales 29-30; upper lateral line 7-8; lower lateral line absent. Yellow; a blackish bar across the interorbital region; dorsal and anal fins with a blackish streak near the edge, which is white.

Total length 75 millim.

Two specimens from Sumbu. Native name: Kilomo.

This species is very closely allied to T. marginatum Blgr., from which it differs in the longer and much more numerous gill-rakers.

Dr. Pellegrin, in his Monograph of the Cichlidæ, p. 331, has expressed his doubts as to the distinctness of $T$. unimaculatum from $T$. marginatum. A renewed examination of the specimens in the British Museum has convinced me that these doubts are not justified. T. unimaculatum differs from $T$. marginatum in having a smaller eye, a narrower interorbital space, a strikingly longer caudal peduncle, much stronger dorsal and anal spines, more numerous gill-rakers (17 or 18 instead of 10 to 16 ), and fewer soft rays in the anal fin ( 7 or 8 instead of 10). Considering that $I$ have before me three specimens of $T$. marginatum and ten of $T$. unimaculatum, I feel confident that such differences, occurring in combination, cannot be merely individual; and the fact that the largest specimen of the former species measures 63 millimetres (without caudal fin) and the smallest of the latter only 70, proves that they cannot be ascribed to age, as suggested by Dr. Pellegrin. The specimens are sufficiently well preserved to show that the second or lower lateral line is totally absent; its representation on Plate XVIII. fig. 3 of my third Report in these 'Transactions' is an error of the artist, which I unfortunately overlooked.

65. Tropheus mooriI Blgr.

A single specimen from Sumbu. Native name: Kifuta.

Dr. Cunnington describes its colour when fresh as: "Dark reddish-brown, with 
some suggestion of green, especially posteriorly; scales in dorsal region outlined with darker; dorsal and anal fins dull red, tipped with black; ventrals dark but reddish."

66. Simochromis diagramma Gthr.

Numerous specimens, measuring from 75 to 185 millim., from Niamkolo, Sumbu, Vua, and Pembe. Native names: Impuma, Mbarama, Modi, Tempendi, Kikalakala.

A female, measuring 92 millim., carries a few embryos in the mouth, these measuring 10 millim. and the vitelline sac $3 \frac{1}{2}$.

Dr. Cunnington has taken the following notes on fresh specimens:- "Olive above, lighter below, but with the scales in the dorsal region darker on the overlap; some 9 or 10 rather faint vertical darker stripes on the body; dorsal with brownish spots, tipped black; anal with dark red border and two red spots posteriorly; caudal darker in the posterior third." Other specimens, of the male sex, are "Greyish above, shading to lighter, almost white below; all scales with olive outlines; head dark above; pectoral and ventral fins with reed upper margins; dorsal tipped red and black; anterior and lower margin of anal bright red, tipped with black." Females have the "Paired fins and the anal olive, the dorsal tipped yellow and black."

\section{Tilapia nilotica L.}

A perfectly typical specimen from Lofu, measuring 310 millim., with dorsal XVII 12 , anal III 10, and 23 gill-rakers on lower part of anterior arch. According to Dr. Cunnington, the fish grows to 390 millim. and occurs not only in Tanganyika itself but also in a small lake and in overflowed rivers near Kombe, on the east coast. Native name: Kiumbwi.

T. nilotica, which has a wide distribution in Africa and Syria, had not previonsly been recorded from further south than Lake Kivu, where specimens were collected by Mr. Moore.

68. Tilapia burtoni Gthr.

Several specimeus from Kituta and Kakonde River, Mtondwe Bay. Native names: Fwili and Sidia.

69. Tilapia latifrons, sp. n. (Plate XL.)

Depth of body barely twice in total length, length of head $3 \frac{1}{4}$ times. Profile of snout descending in a steep, straight line; eye twice in length of snout, 5 times in length of head, twice and $\frac{1}{4}$ in interorbital width; mouth extending to between nostril and eye; outer teeth strong, bicuspid, followed, after an interspace, by small tricuspid teeth forming 5 series in the upper jaw and 4 in the lower; 3 series of scales on the cheek; large scales on the opercle. Gill-rakers short, 9 on lower part of anterior arch. Dorsul XVI 13; spines strong, increasing in length to the last, which measures $\frac{1}{2}$ 
length of head; median soft rays produced, longer than head. Anal III 11; spines stronger but shorter than dorsals, third $\frac{1}{3}$ length of head; median soft rays produced, like the dorsals. Pectoral acutely pointed, as long as head, not reaching origin of anal. Ventral reaching vent. Caudal peduncle deeper than long. Caudal truncate, slightly emarginate. Scales finely denticulate, $32 \frac{3}{12}$; lateral lines $\frac{2 \mathrm{I}}{13}$. Olive-green above, the scales outlined with black, bluish green to white beneath; cheek and opercle mottled green and blue, with some black; a black opercular spot; dorsal black, with regular large round blue spots, towards the edge turning to yellow with white spots; anal and caudal similarly coloured, but the spots less distinct; pectorals brown, ventrals grey.

Total length 260 millim.

A single specimen from Kituta. Native name: Ntunka.

This fine Tilapia is allied to T. melanopleura A. Dum. (lata Gthr.), but the interorbital space is considerably broader, there are 11 soft rays in the anal instead of 9 or 10 , and the markings on the fins are different.

70. Tilapia HoRi Gthr.

Two adult specimens, measuring 140 millim., from Niamkolo, native name Songa Matete, and one young, measuring 75 millim., from Sumbu, native name Kilomo. Two of these specimens have 8 soft rays in the anal fin. I no longer regard T. rubropunctata Blgr. as separable from $T$ horii.

71. Tilapia Dardennit Blgr.

Five specimens, measuring 175 to 240 millim., from Niamkolo. Native names: Sangani, Nkungula, Masangano.

Females have the mouth and pharynx filled with eggs, 5 or 6 millim. in diameter.

72. Tilapia labiata Blgr.

Three specimens, measuring 330,190 , and 95 millim. respectively; two from Niamkolo and one from the Kakonde River, running into Mtondwe Bay. Native name: Kawbo or Dafwa.

All three specimens have the produced lips characteristic of the species. Dorsal XVII 10-11; Anal 1II 7; 16 to 20 gill-rakers on lower part of anterior arch. Dorsal and anal with round reddish-yellow spots between the soft rays; a yellow spot on the middle of the ventral.

73. 'Tilapia Microlepis Blgr.

Two specimens, measuring 285 and 265 millim. respectively, from Niamkolo. Native name: Kupi or Kuhi. 
Dr. Cunnington measured a specimen 610 millim. long, and notes that the fish is said to grow still larger.

\section{Tilapia grandoculis Blgr.}

Three specimens from Niamkolo, native name Weswa, and one from Sumbu, native name Kisangi.

Dorsal XIII-XIV 13-14; Anal III 9; Scales 58-65 $\frac{5-6}{20-22}$; Lateral lines $\frac{53-55}{22-31} ; 14$ to 16 gill-rakers on lower part of anterior arch. The ventrals do not extend beyond the origin of the anal.

Dr. Cunnington describes the coloration as dark olive-brown above, shading to lighter, with some yellow, below; a series of about tive irregular blackish blotches on the side of the body; dorsal with yellow spots, tipped black; pectoral slightly, ventral strongly tinged with yellow; anal with yellow markings; proximal half of caudal darker than the rest.

75. Petrochromis polyodon Blgr.

Two specimens from Niamkolo and one from Pembe. Native names: Infutu and Ilumbu.

In the largest specimen, 170 millim. long, the depth of the body equals the length of the head, the diameter of the eye is contained nearly 5 times in the length of the head and once and $\frac{2}{3}$ in the interorbital width. There are 6 series of scales on the cheek, and 19 spines in the dorsal fin. Its colour when fresh is noted as "Greenish brown over most of the body, but a little lighter below, with a patch of rather darker colour at the edge of each scale." A smaller specimen is described as "Olive above, shading off to lighter and greyish below, scales outlined by rather darker shade; dorsal fin with reddish tinge in anterior region and tipped black; anal with several prominent spots of bright yellow ; distal half of ventrals slightly reddish."

76. Petrochromis tanganicer Gthr.

One specimen from Niamkolo and one from Kituta. Native name: Kilongo.

Cunningtonia, g. n.

Jaws with broad bands of minute, bristle-like teeth with incurved tricuspid crowns. Maxillary largely exposed at the end. Body moderately elongate, covered with small, feebly ctenoid scales; two lateral lines, the upper complete. Dorsal with 13 spines, anal with 3. Vertebræ $36(18+18)$.

Agrees with Petrochromis in the dentition, differs in the maxillary bone being largely exposed when the mouth is closed. 
77. Cunningmonia longiventralis, sp. n. (Plate XLI. fig. 2.)

Depth of body equal to length of head, 3 times in total length. Snout broad, very convex, shorter than the eye, which is $2 \frac{1}{2}$ times in length of head and equals interocular width; maxillary extending to below anterior border of eye; 2 or 3 series of small scales on the cheek; large scales on the opercle. Gill-rakers rather short, 13 on lower part of anterior arch. Dorsal XIII 13; spines weak, subequal from the 7 th, nearly $\frac{1}{2}$ length of head; posterior soft rays produced, $\frac{3}{4}$ or $\frac{4}{5}$ length of head. Anal III 8-9; spines weak, 3rd $\frac{1}{3}$ length of head; soft rays produced like the dorsals. Pectoral acutely pointed, as long as head, reaching beyond origin of anal. Ventral produced into a very long filament, nearly twice as long as head. Caudal peduncle once and $\frac{1}{2}$ as long as deep. Caudal with deep crescentic notch. Scales $38 \frac{4}{14-15}$; lateral lines $\frac{33}{15-18}$. Bluish black above, bright silvery beneath; fins blackish.

Total length 110 millim.

Two specimens from Niamkolo. Native name: Kalilolilo.

This fish bears a striking resemblance to Tilapia boops Blgr., in which, however, the dentition is very different and the maxillary bone is almost concealed when the mouth is closed, and the vertebræ are fewer $(16+16)$.

\section{Eretmodus cyanostictus Blgr.}

Two specimens from Niamkolo Bay and one from Sumbu. Native name: Kamfoto.

Dr. Cunnington describes the colour as dark brownish grey with a number of scattered spots of a brilliant blue.

The specimen from Sumbu, a female measuring 75 millim., contained developing embryos in the month; some of them dropped out before the specimen could be preserved.

79. Xenochromis HeCQui Blgr.

A single specimen from Moliro. Confounded by the natives with the following species under the name of Komangingi.

80. Plecodus paradoxus Blgr.

Two specimens from Kasakalawe (native name Nkanka), two from Niamkolo (n. n. Nswepa), one from Sumbu and one from Moliro (n. n. Komangingi).

As this remarkable fish was only known from young and defective specimens, a new description from the material now at hand seems desirable.

Depth of body nearly equal to length of head, $3 \frac{1}{2}$ to 4 times in total length. Snout short and convex, as long as the eye in the adult, shorter in the young; diameter of eye 3 to $3 \frac{1}{2}$ times in length of head, once to once and $\frac{1}{3}$ in interorbital width; mouth 
extending to below anterior fourth of eye; jaws strong, lips thick; 18 or 20 teeth in the upper jaw, 14 or 16 in the lower; interocular region scaly, convex; 3 or 4 series of scales on the cheek; larger scales on the opercle. 18 to 20 gill-rakers on lower part of anterior arch, the posterior rather elongate. Dorsal XIX-XX 11-13; spines rather strong, subequal from the 8 th or 9 th, $\frac{2}{5}$ to $\frac{1}{2}$ length of head; posterior soft rays longest, $\frac{3}{5}$ length of head. Anal III 12-13; spines very strong, third longest, $\frac{2}{5}$ to $\frac{1}{2}$ length of head. Pectoral acutely pointed, $\frac{3}{4}$ to $\frac{4}{5}$ length of head. Ventral not reaching anal. Caudal peduncle once and $\frac{2}{3}$ to twice as long as deep. Caudal with deep crescentic notch. Scales $75-78 \frac{5-6}{18-19}$; lateral lines $\frac{58-66}{44-53} ; 5$ series of scales between the lateral lines anteriorly. Olive-grey above, in the fresh condition, shading to whitish below, with 7 or 8 somewhat irregular, yellowish-brown longitudinal lines; two or three ill-defined dark brown bars across the back and a round spot at the root of the caudal fin sometimes present; a black opercular spot; dorsal and caudal fins brown, with round yellow spots.

Total length 290 millim.

The vertebræ number $38(18+20)$. The occipital crest is very strong.

M A STACEM BELID

\section{Mastacembelus mooril Blgr.}

Five young specimens, 40 to 70 millim. long, from Utinta, dredged among shells in about 15 fathoms. Native name: Molombo.

The dorsal spines number 26 or 27.

82. Mastacembelus cunningtoni, sp. n. (Plate Xli. fig. 3.)

Depth of body 10 to 11 times in total length, length of head 7 to $7 \frac{1}{2}$ times. Vent equally distant from end of snout and from root of caudal fin, its distance from the head equal to $2 \frac{1}{2}$ to $2 \frac{3}{4}$ times length of latter. Snout 3 to 4 times as long as eye, ending in a trifid appendage which is a little longer than the latter; cleft of mouth extending to below nostril or not quite so far ; a strong, erectile spine below the nostril; two strong præopercular spines. Dorsal XXIX 95-105, spines increasing in length; anal II 115-125, second spine equal to penultimate dorsal; both fins completely embracing the rounded caudal ; the distance between the first dorsal spine and the head 3 to $3 \frac{1}{2}$ times in length of latter. Pectoral twice and $\frac{1}{2}$ to 3 times in length of head. Scales very small, 26 to 28 between origin of soft dorsal and lateral line. Uniform brown above, or olive-brown mottled with darker, white beneath; caudal blackish, edged with orange.

Total length 580 millim.

Two specimens from Kituta, native name Morobe, and one from Kazzaga, native name Molombo. 
Closely allied to $M$. congicus Blgr.; distinguished by the fin-formula and the coloration.

\section{Mastacenbelus taniatus Blgr.}

Two young specimens, 75 and 38 millim. long, one from Niamkolo Bay (native name Morobi), the other from Kasawa (native name Molombo).

The dorsal spines number 33 or 35 .

84. Mastacembelus ophidium Gthr.

A single specimen, measuring 330 millim., from Burton Gulf. Native name: Molombo.

Length of head $8 \frac{1}{2}$ times in total length. 33 dorsal spines. Pale olive-brown above, with roundish spots of a dark brown; white beneath; dorsal and pectorals spotted with brown; anal and caudal of a light orange colour, unspotted.

We are now acquairited with 7 species of Mastacembelus from Lake Tanganyika. They may be distinguished as follows :-

I. Vent equally distant from end of snout and from root of caudal fin.

A. No præopercular spine.

Dorsal XVIII 85; Anal II 90 . . . . . . . . . . . . . . . M. frenatus Blgr.

Dorsal XXV-XXVIT 70-80; Anal II 70-80 . . . . . . . . . . M. moorii Blgr.

B. Two preopercular spines.

Dorsal XXIX 95-105; Anal II 115-125 . . . . . . . . . . . M. cunningtoni Blgr.

II. Vent nearer caudal fin than end of snout.

A. One or two præopercular spines.

Dorsal XXXI 70; Anal II 70 . . . . . . . . . . . . . . . M. ellipsifer Blgr.

Dorsal XXXVI-XXXIX 50-60; Anal II 50-60 . . . . . . . . . M. tanganica Gthr.

$B$. No præopercular spine.

Dorsal XXXIII-XXXV 85; Aual II 85 . . . . . . . . . . M. teniatus Blgr.

III. Vent nearer end of snout than caudal.

Dorsal XXX-XXXIII 100-120; Aual I 115-130 . . . . . . . . M. ophidium, Gthr. 


\section{PLATE XXX.}

vol. XVII.-PaRT vi. No. 6.- Octoler, 1906. 


\section{PLA'TE XXX.}

Fig. 1. Marcusenius tanganicanus, p. 545. $\frac{4}{5}$ nat. size.

2. Pellonula miodon, p. 546.

3. Alestes rhodopleura, p. $547 . \quad \frac{3}{4}$ nat. size. 

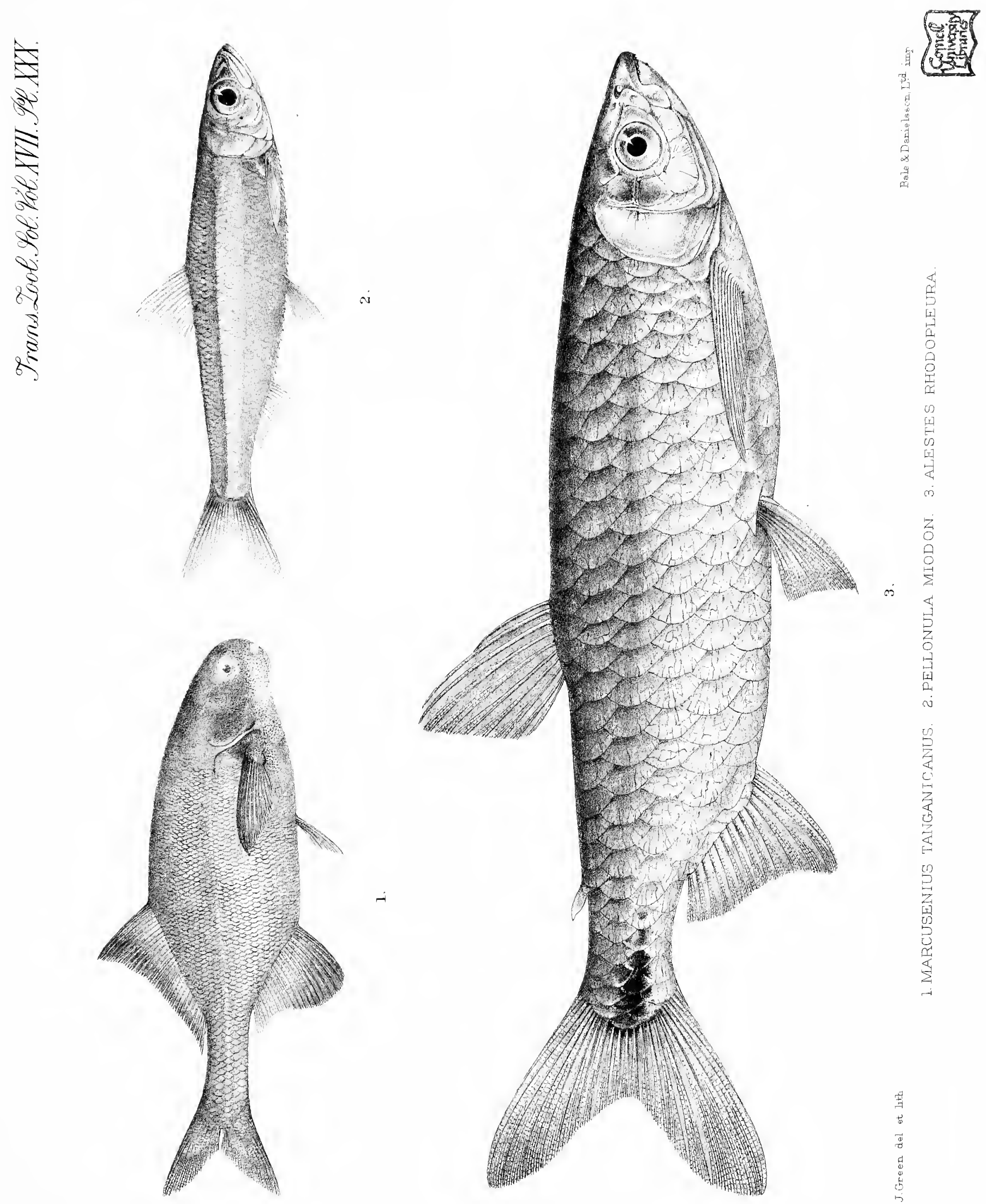

PLATE XXXI.

4 н 2 


\section{PLATE XXXI.}

Dinotopterus cunningtoni, p. 550.

$\alpha$. Adult, $\frac{1}{2}$ nat. size; $b$. Upper view of head, $\frac{1}{2}$ nat. size; $c$. Dentition, natural size; d. Young, natural size. 


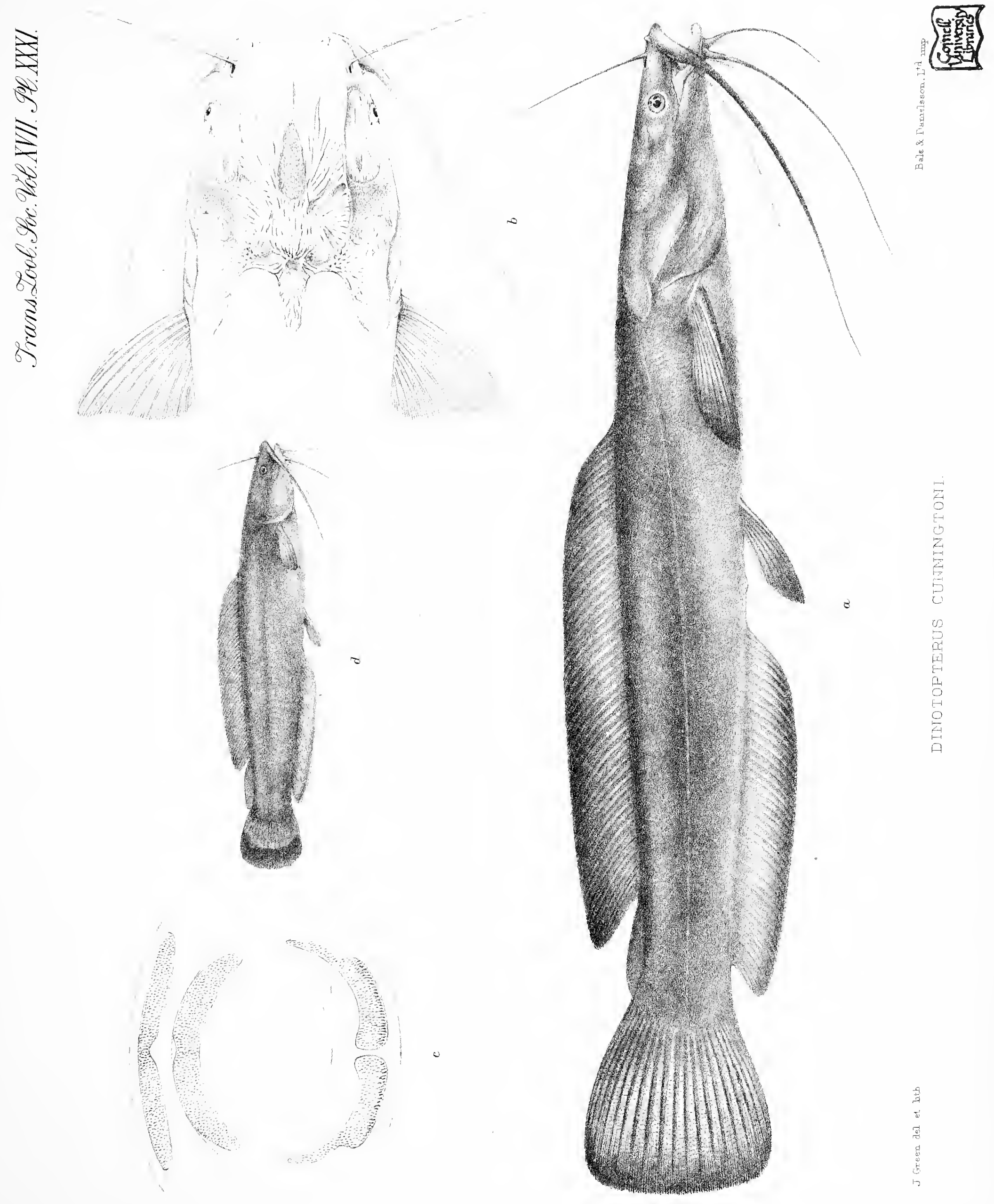





\section{PLATE XXXII.}




\section{PLA'TE XXXII.}

Fig. 1. Neobola minuta, p. 549. Enlarged.

2. Chrysichthys sianenna, p. 551 .

3. Phyllonemus typus, p. 552.

4. Haplochilus pumilus, p. 554. 


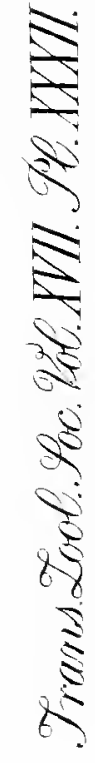

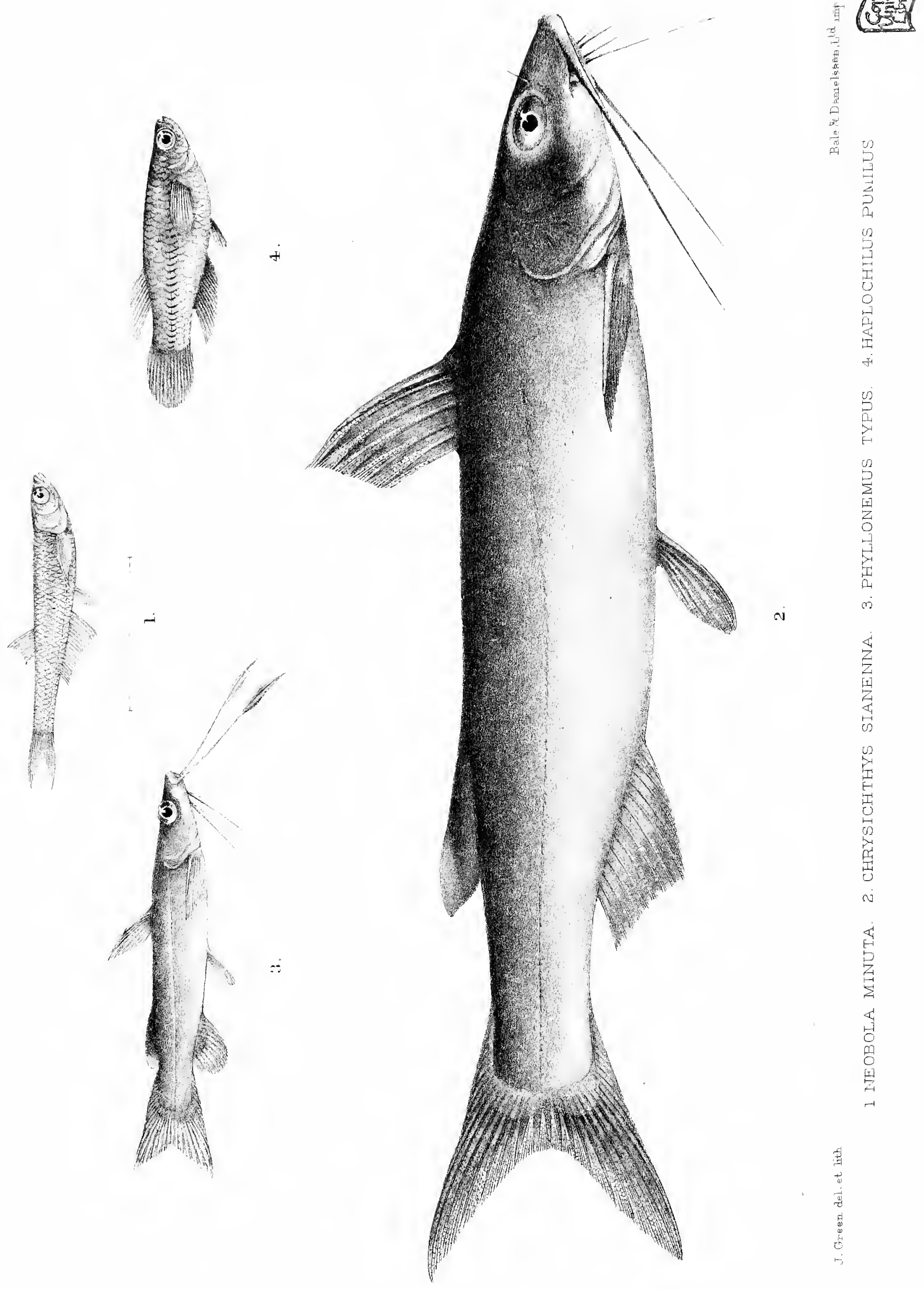





\section{PLATE XXXIII.}


PLATE XXXIII.

Auchenoglanis occidentalis, var. tanganicanus, p. 553, with upper view of head and open mouth. 


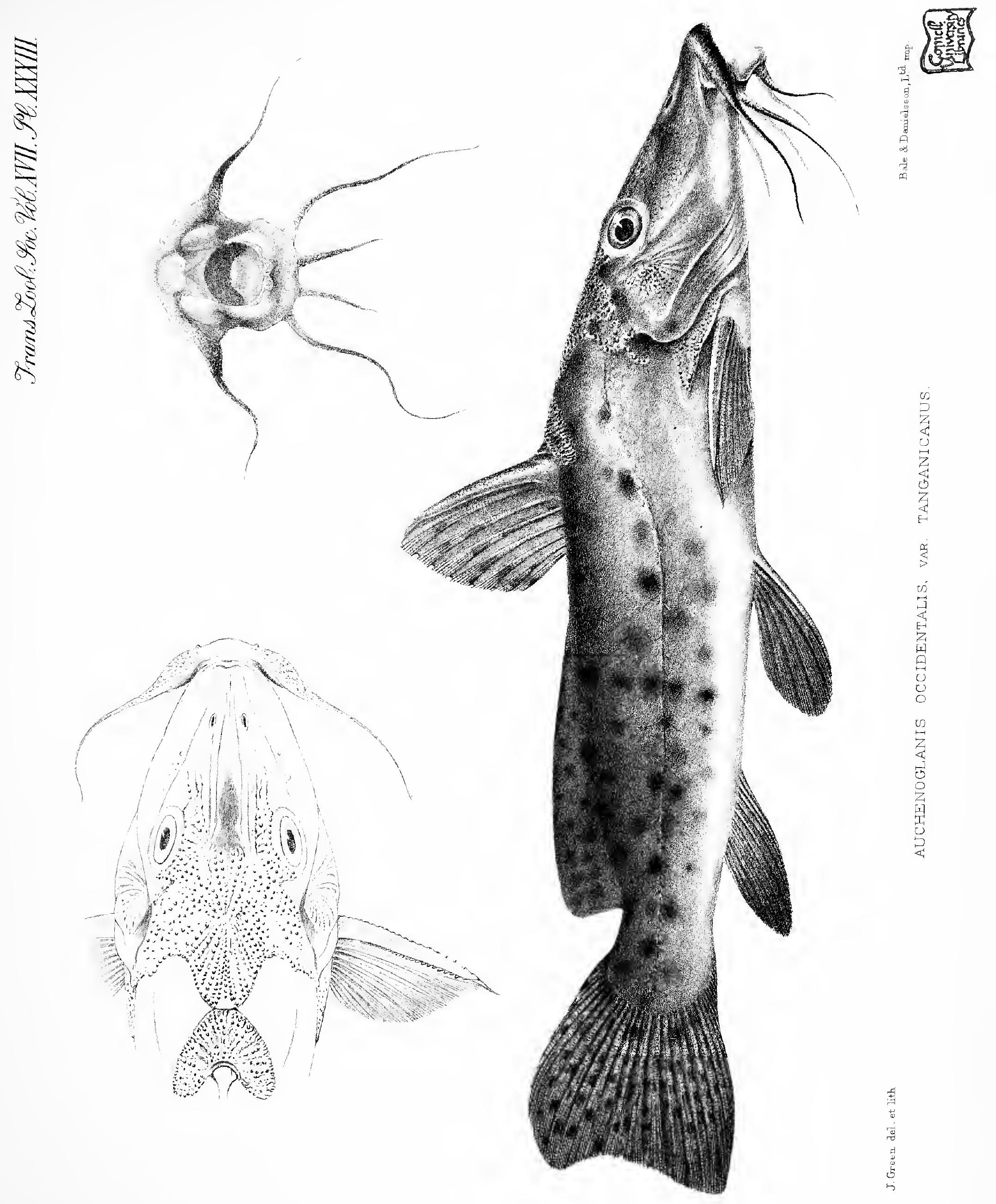





\section{PLATE XXXIV.}

vol. xvil.-PART VI. No. 7.-October, 1006. 


\section{PLATE XXXIV.}

Synodontis melanostictus, p. 553,

with upper and lower views of head.

$\frac{7}{8}$ natural size. 


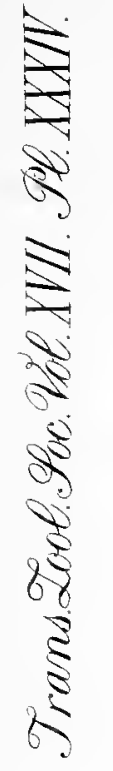
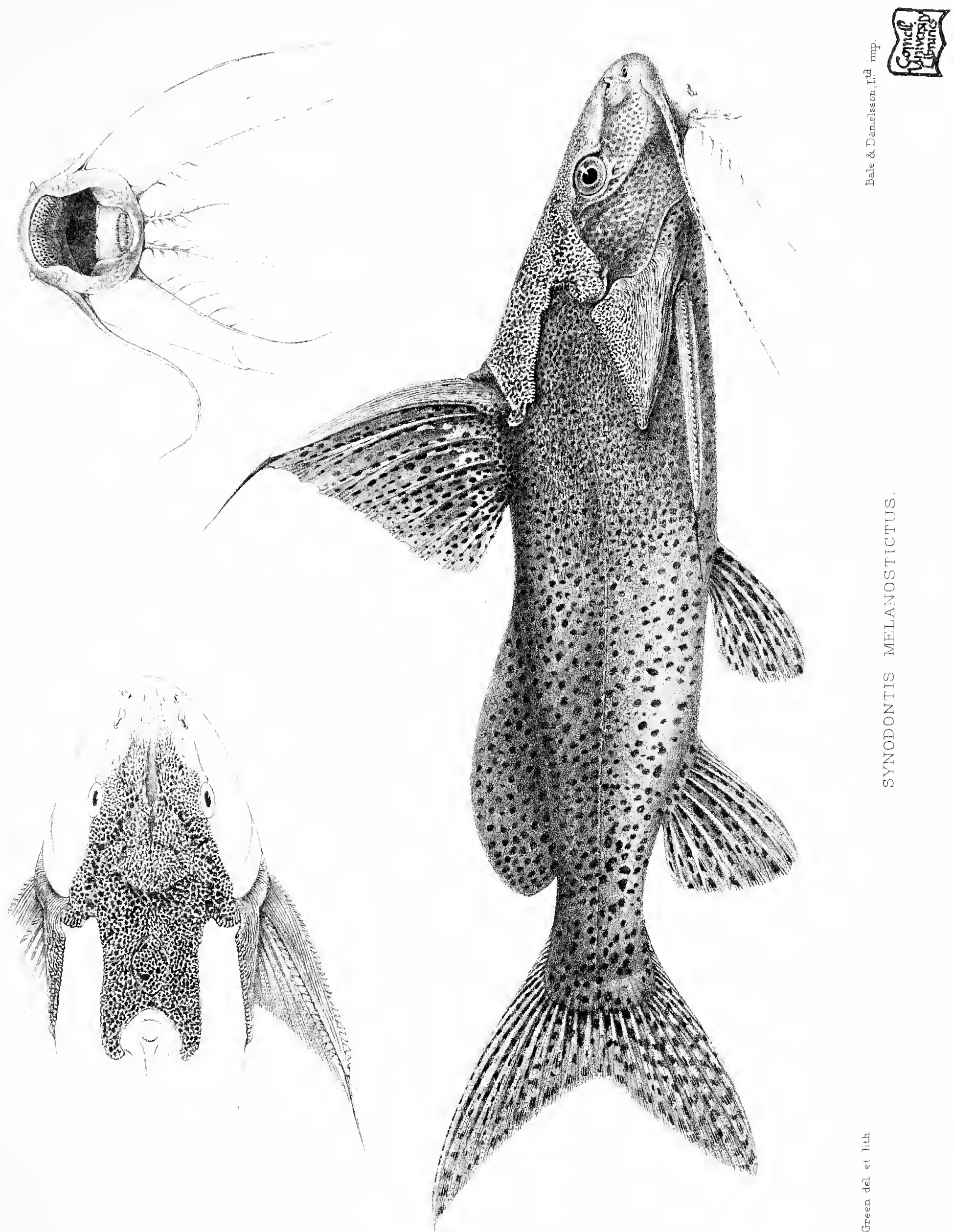

PLATE XXXV.

412 


\section{PLATE XXXV.}

Fig. 1. Lates angustifrons, p. 555.

1 a. , upper view of head.

2. "microlepis, p. 555, upper view of head.

3. Lamprologus multifasciatus, p. 558.

4. $\quad . \quad$ reticulatus, p. 560 .

5.,$\quad$ calliurus, p. 560 . 


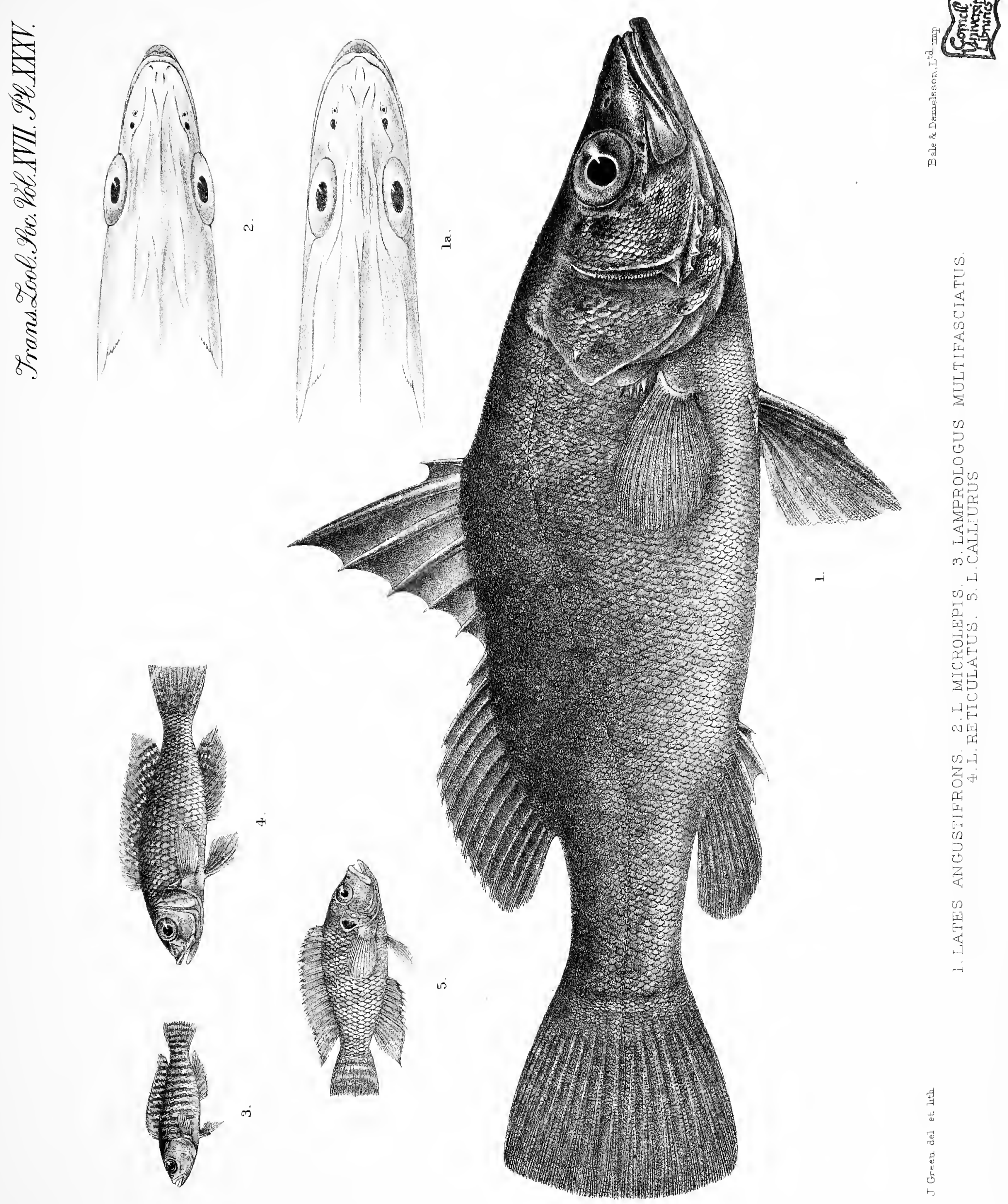



PLATE XXXVI. 


\section{PLA'TE XXXVI.}

Fig. 1. Lamprologus brevianalis, p. 555.

2. $\quad$ cunningtoni, p. 557.

3. " mondabu, p. 557.

4. " $\quad$ callipterus, p. 559. 

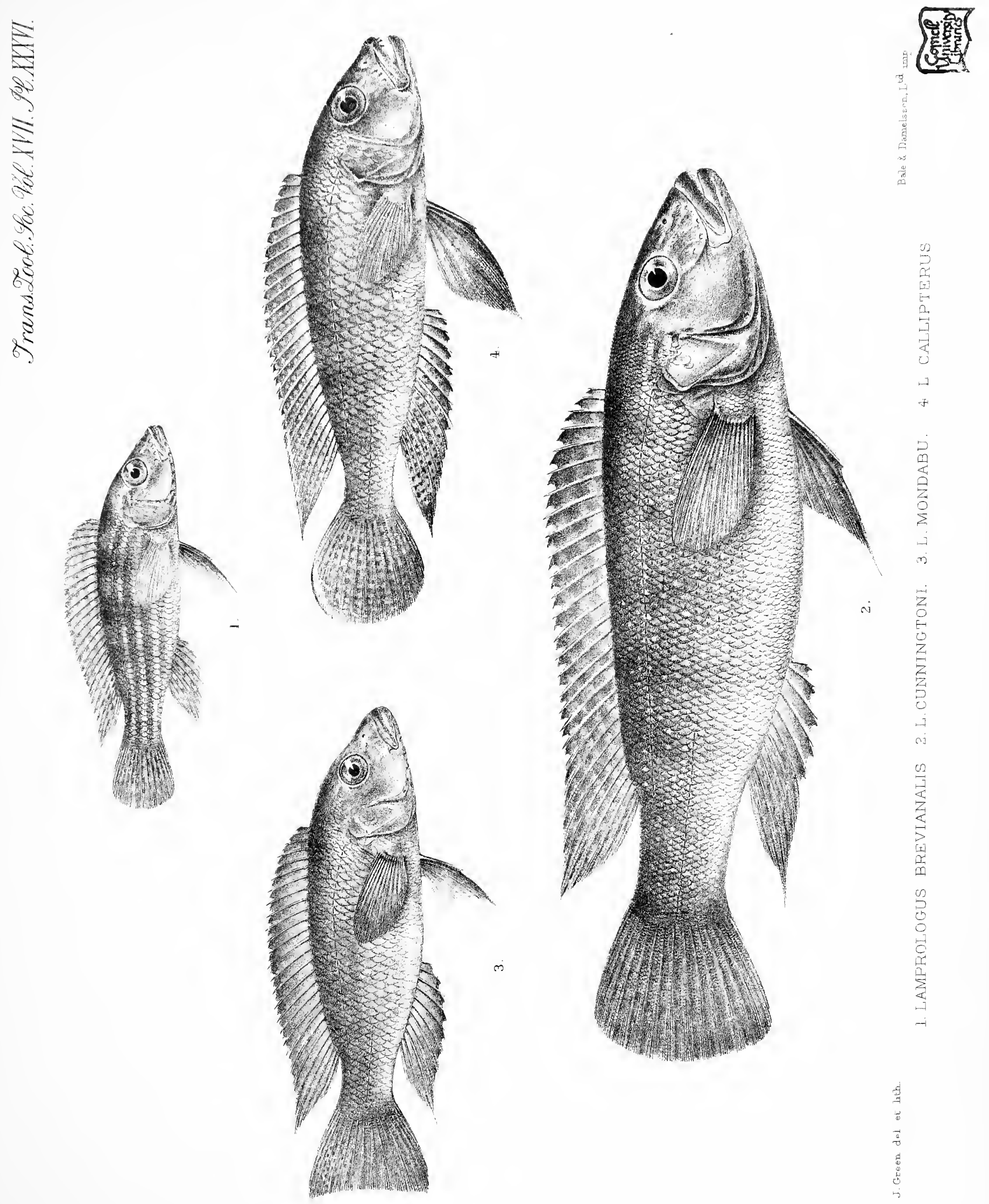



\section{PLA'TE XXXVII.}




\section{PLATE XXXVII.}

Fig. 1. Paratilapia frontosa, p. 561. 1a. Dentition.

2. Pelmatochromis polylepis, p. 566, young. 


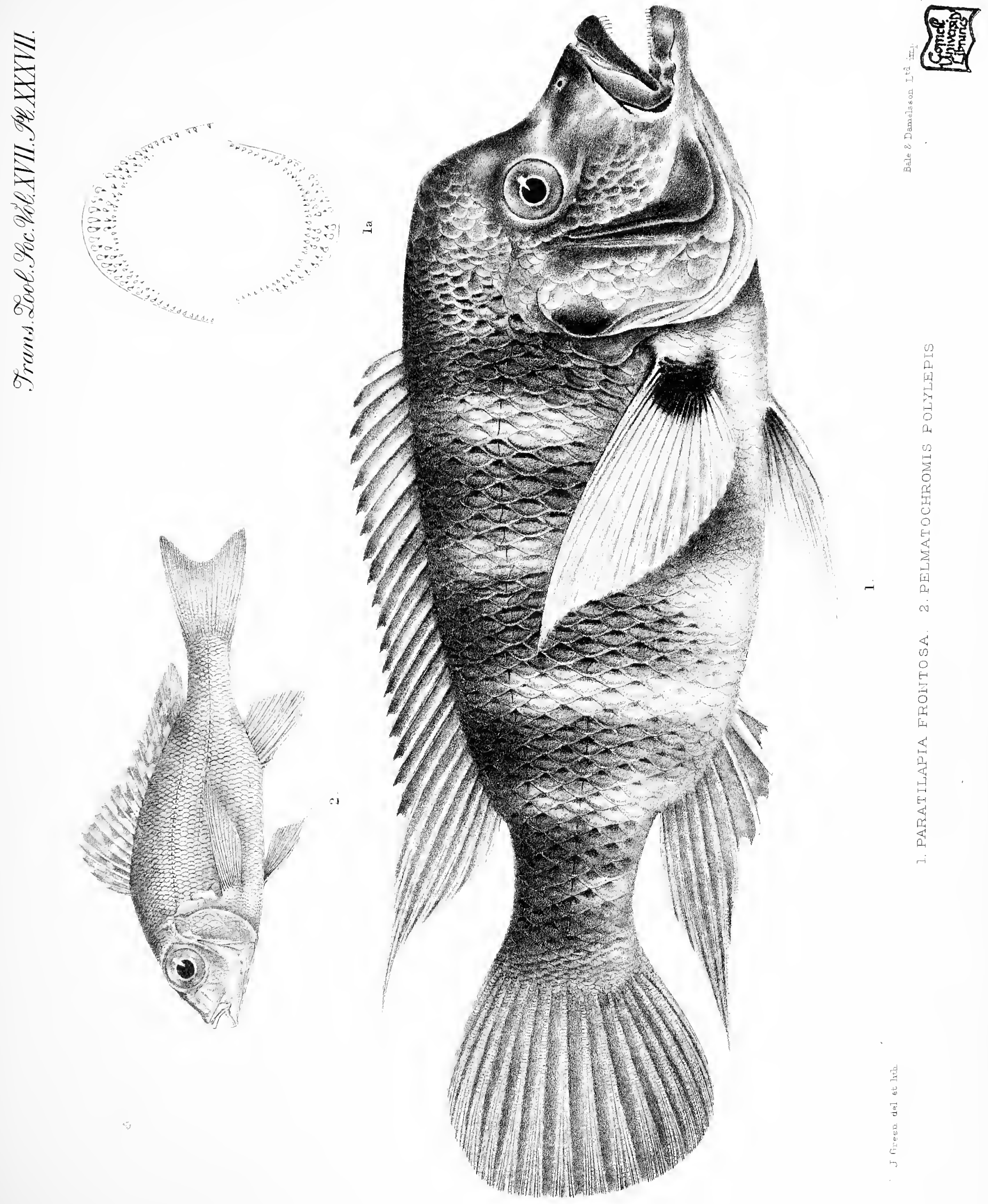





\section{PLATE XXXVIII.}

vol. XVII.-PaRT vi. No. 8.-October, 1906. 
FISHES FROM LAKE TANGANYIKA.

\section{PLATE XXXVIII.}

Fig. 1. Bathybates minor, p. 564.

2. Haplotaxodon microlepis, p. 566. 

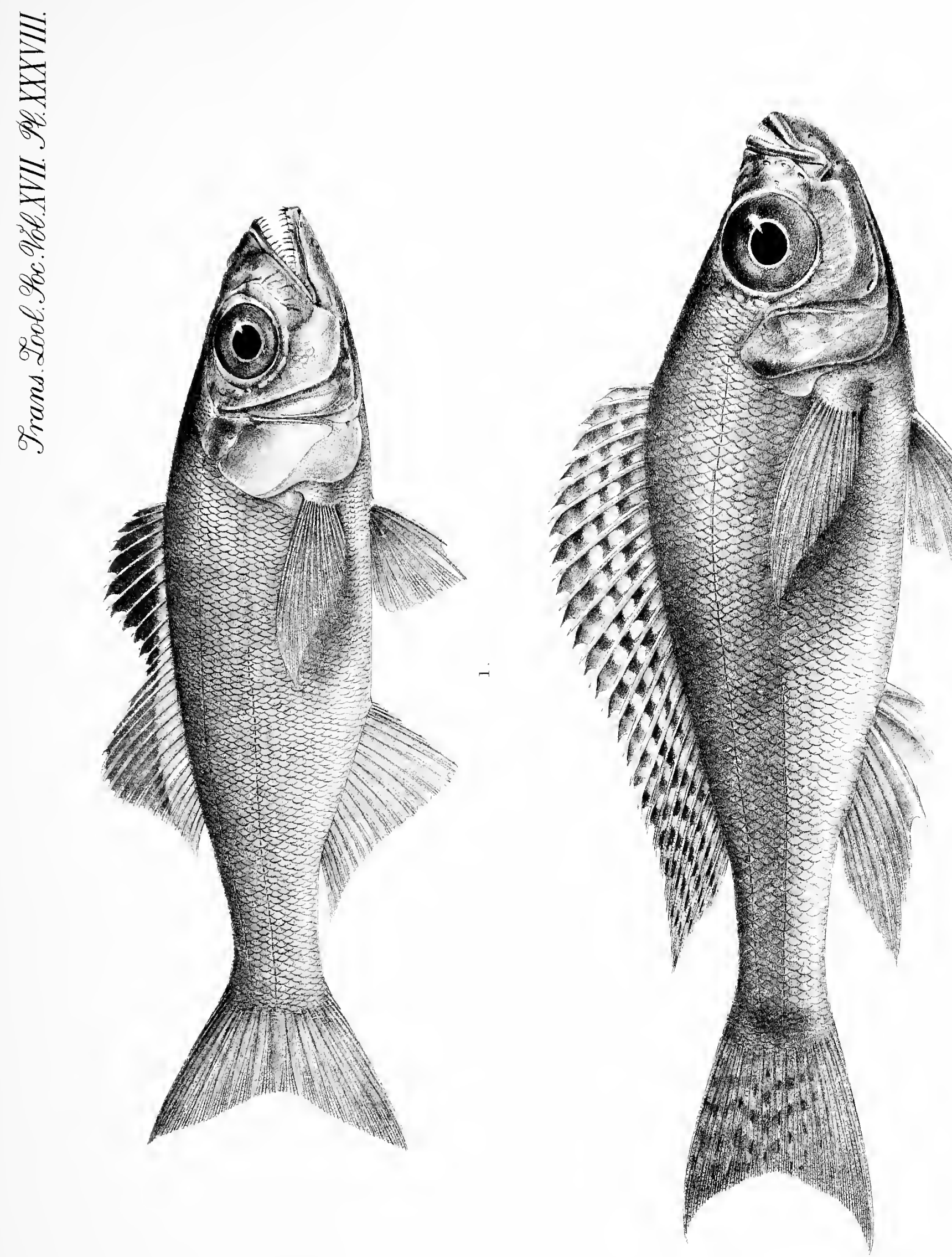

邀
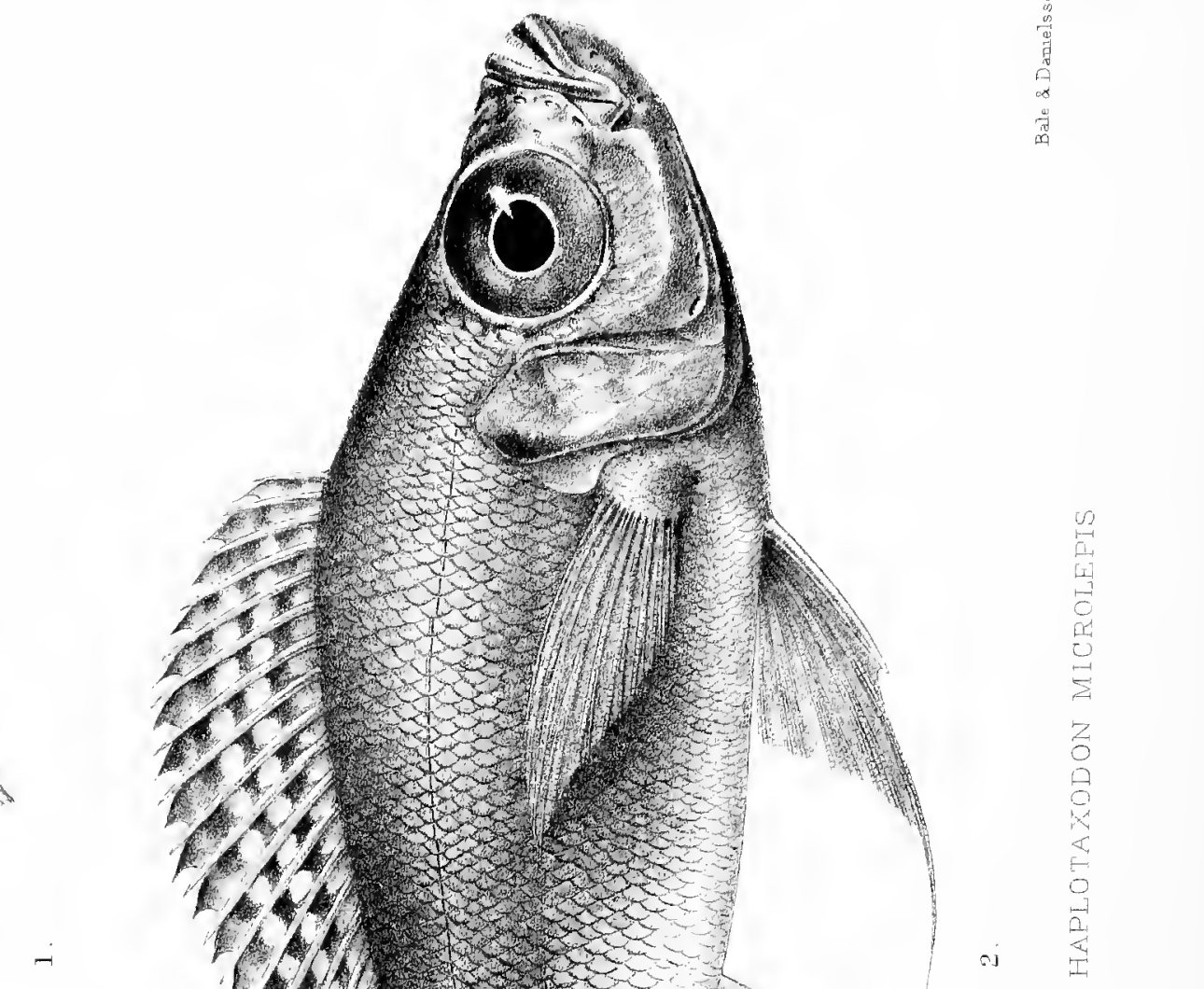

PLATE XXXIX.

4 к 2 


\section{PLATE XXXIX.}

Fig. 1. Pelmatochromis melanostigma, p. 567.

2.

3.

$3 a$.

4.

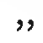

"

,

, pleurospilus, p. 567.

rhodostigma, p. 568.

lower surface of head and anterior part of body. 

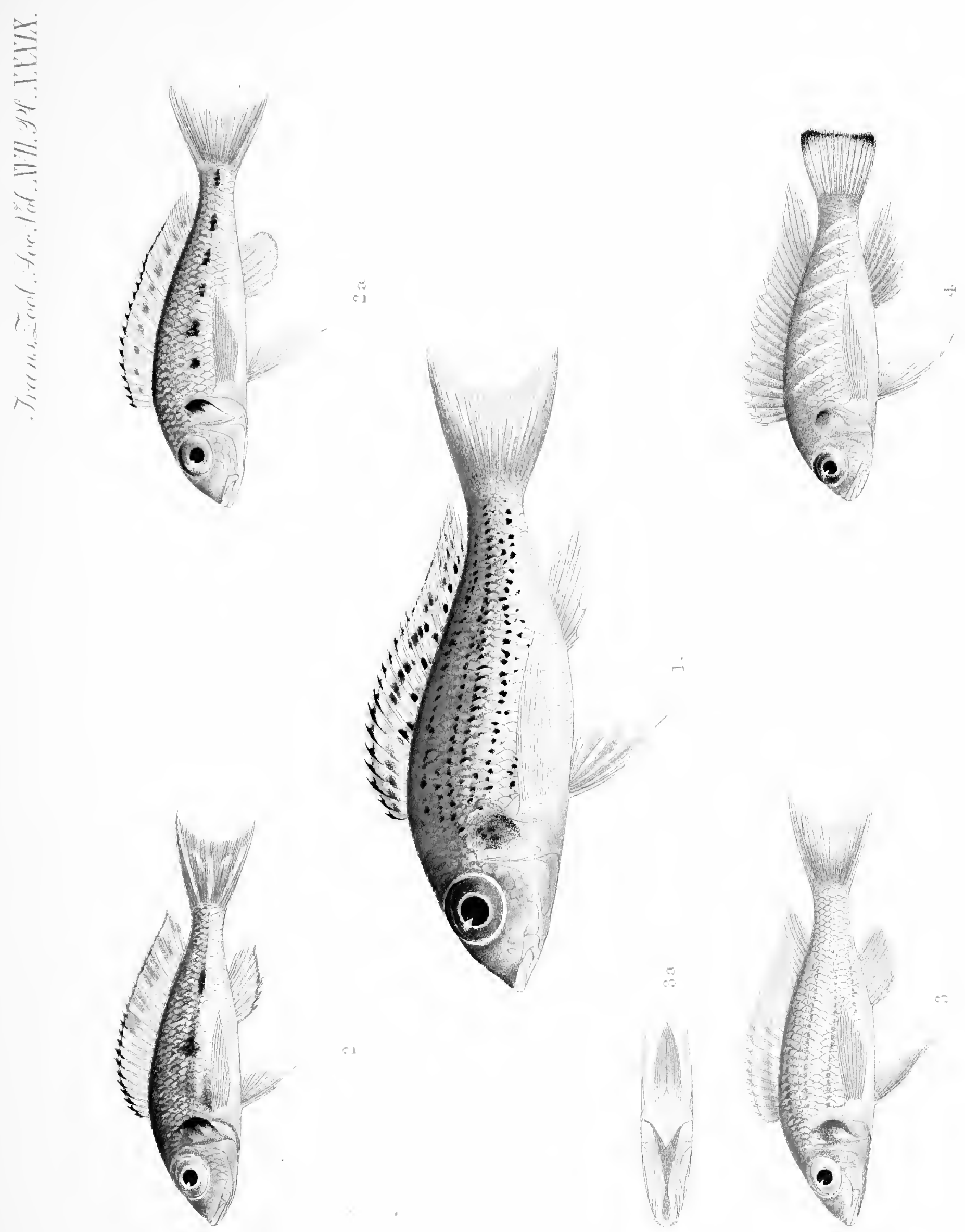

PLATE XL。 


\section{PLATE XL.}

Tilapia latifrons, p. 571. 
हैं

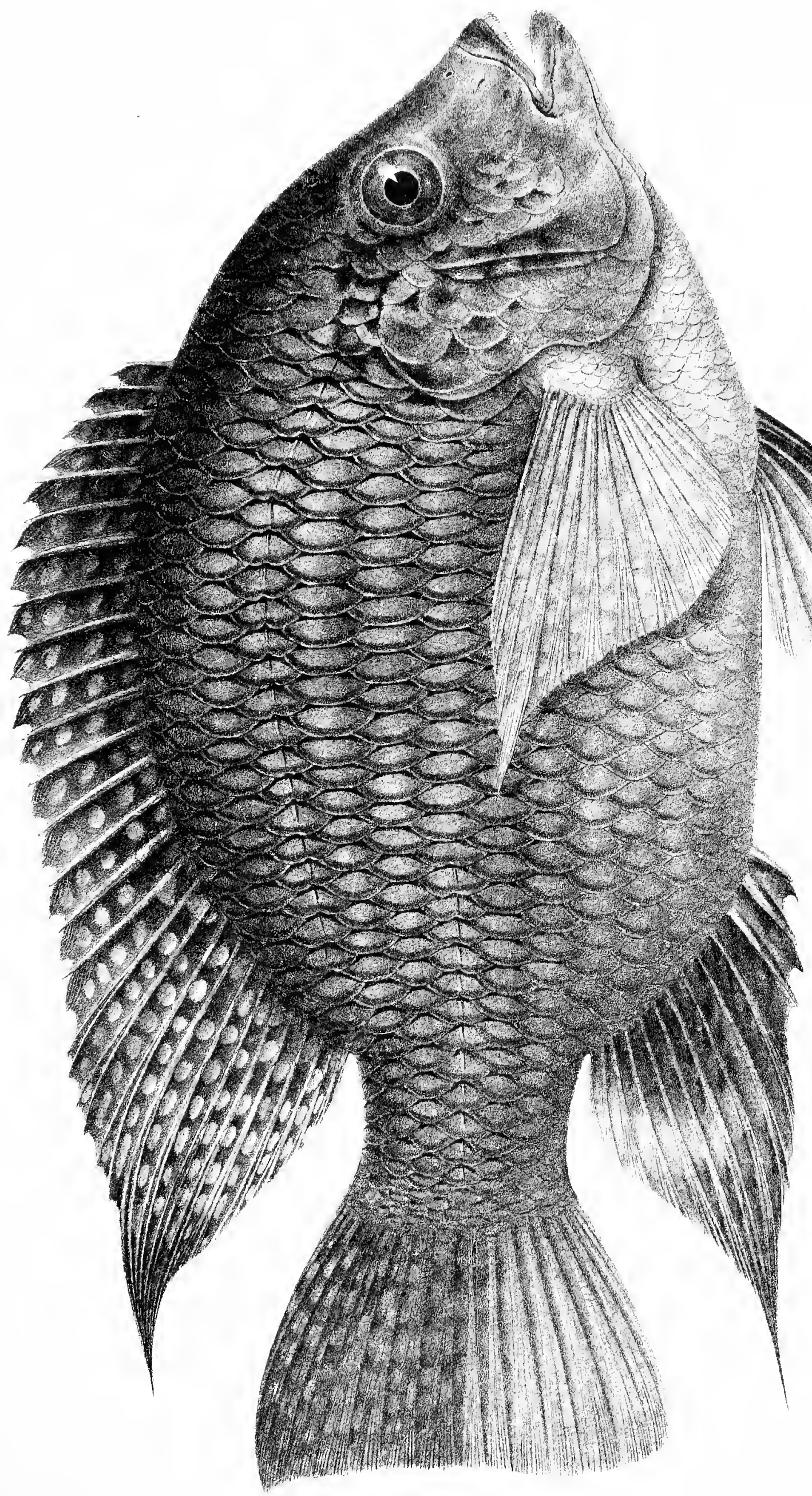

鹤 

PLATE XLI. 
PLATE XLI.

Fig. 1. Trematocara nigrifrons, p. 570.

2. Cunningtonia longiventralis, p. 574.

3. Mastacembelus cunningtoni, p. 575. $\frac{3}{4}$ nat. size.

$3 a$. Ditto: upper view of head. $\frac{3}{4}$ nat. size. 

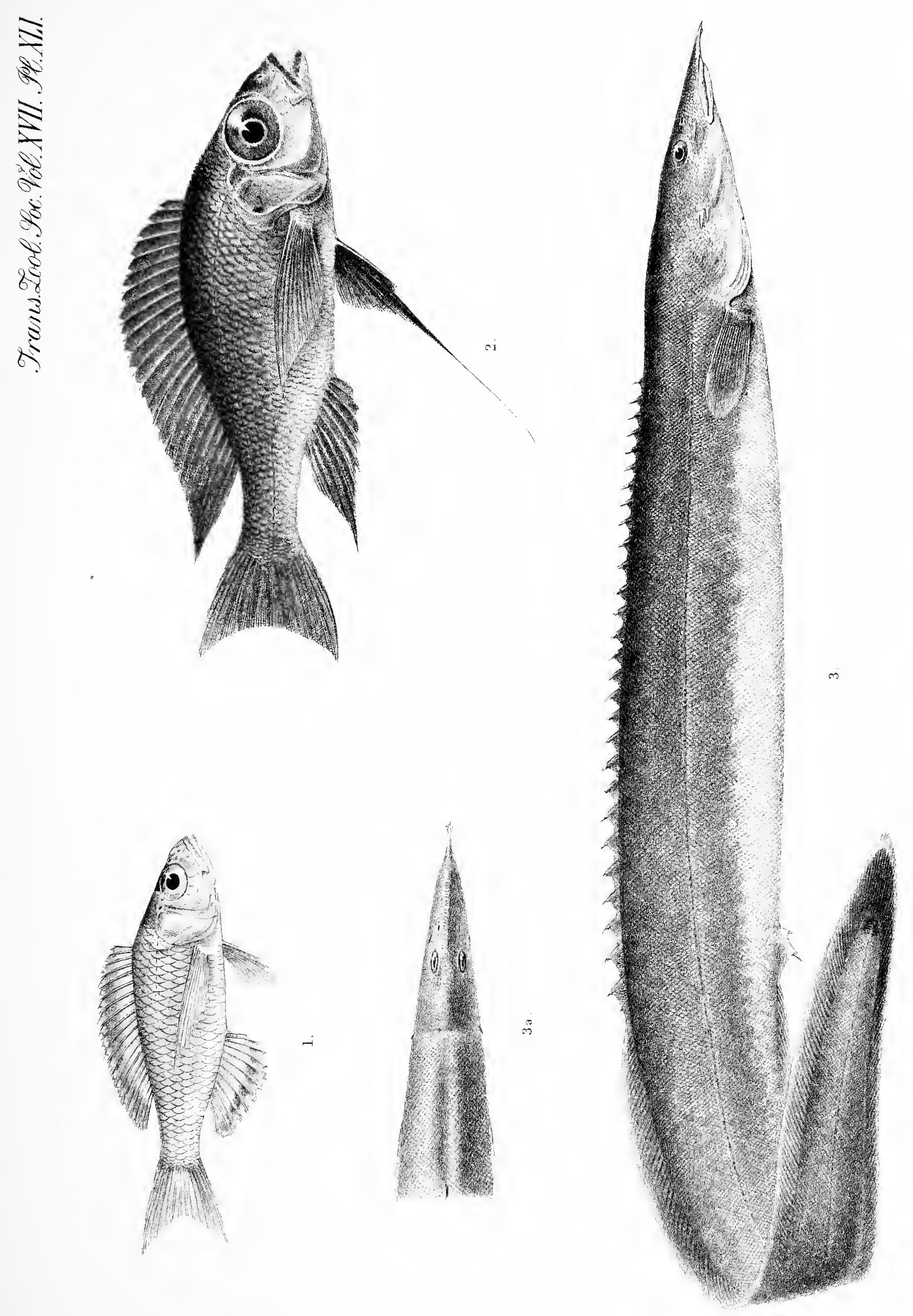

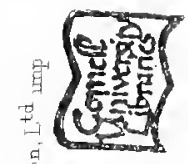
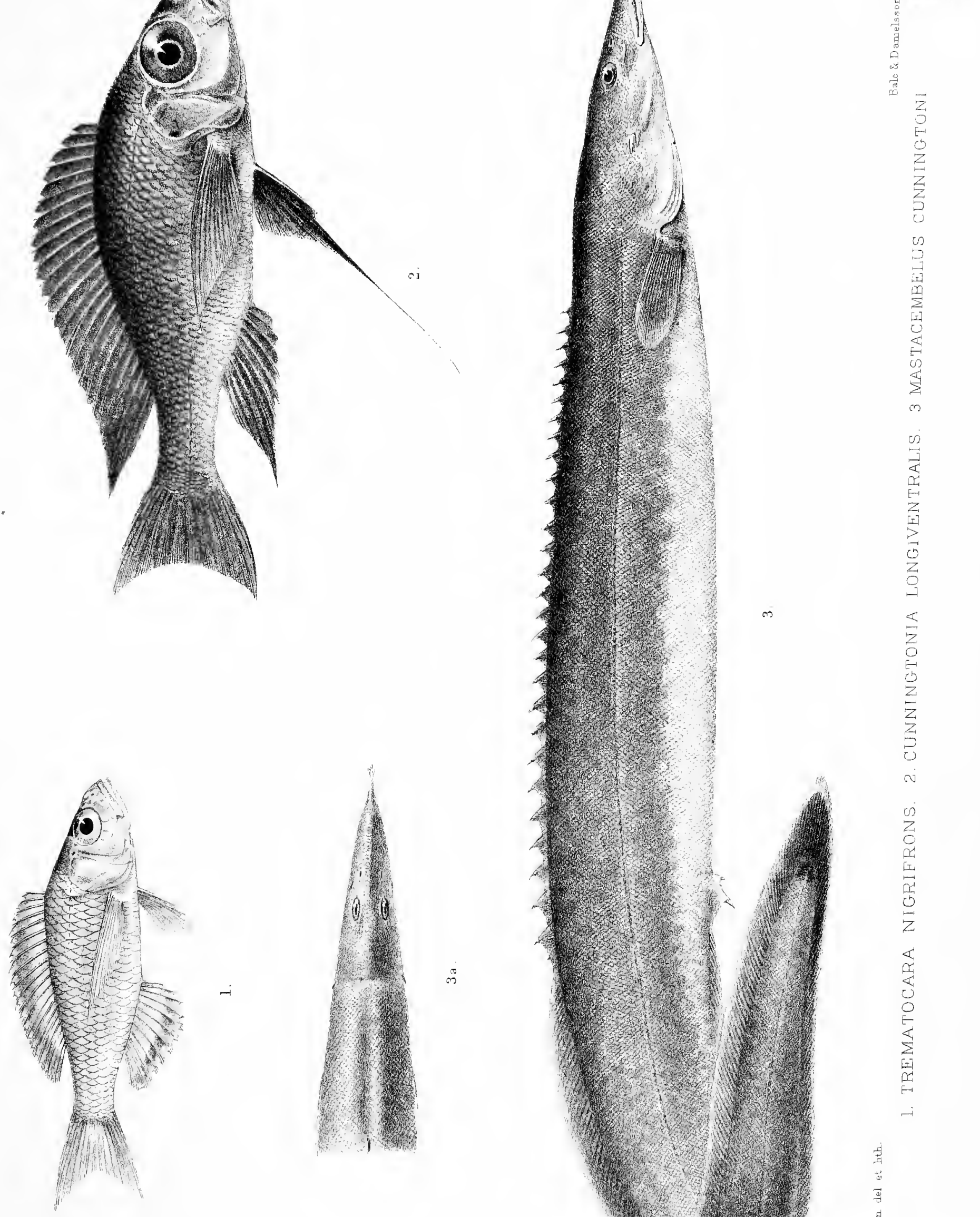

LIST OF THE PAPERS CONTAINED IN VOL. XVII.

Bethune-Baker, George T., F.L.S., F.Z.S., \&c.

A Revision of the Amblypodia Group of Butterflies of the Family Lyccenidoe . . Bodleneer, Gerge Albert, F.R.S., V.P.Z.S.

$A$ Contribution to our Knowledge of the Varieties of the Wall-Lizard (Lacerta muralis) in Western Europe and North Africa ............... 351

Fourth Contribution to the Ichthyology of Lake Tanganyika.-Report on the Collection of Fishes made by Dr. W. A. Cunnington during the Third Tanganyika Expedition, 1904-1905 .
Page

Mrtcheld, P. Chalaers, M.A., D.Sc., Secretary to the Society.

On the Intestinal Tract of Mammals ... 437

Pegan, C. Tate, B.A., F.Z.S.

A Monograph of the Fishes of the Family

Loricariide ............... 191

vol. XVII,-PaRT Vi. No. 9.-October, 1906. 



\section{INDEX OF SPECIES, ETC., IN VOL. XVII.}

Acanthicus, 261.

- genibarbis, 219.

hystrix, 262.

Acesina, 25.

- aberrans, 144.

- ariel, 145.

__ arisba, 144.

— paraganesa, $145 \overline{.}$

- zephyretta, 14 j.

Acestra, 302.

- acus, 304 .

- amazonum, 305.

— gladiolus, 305 .

-- glaclius, 303.

- knerii, 304 .

- oxyrhynchus, 304 .

Africa, on transformations of Lepidoptera of South, 165.

_ 351.

Alactaga indica, 482.

Alestes, 543.

- batesii, 548.

_ brevis, 548 .

__ grandisquamis, 548.

- macrolepidotus, 548.

- macrophthalmus, 540, 547.

___ rhodopleura, 540, 547, 578.

Amblypodia group of the Lycænidæ, revision of the, 1.

Amblypodia, 1, 15, 25.

- abseus, 112.

acetes, 45 .

achelous, 82.

acron, 140.

adatha, 69.

admete, 141.
Amblypodia adonias, 102.

- aedias, 124.

- cexone, 35.

- agaba, 83.

— agelastus, 136.

- agesias, 95.

——agesiluus, 93 .

- aglais, 44 .

- agnis, 125.

__ alaconia, 101.

- albopunctata, 60 .

- alce, 75, 76.

- alea, 133.

- alitceus, 61.

- allata, 128.

- amantes, 42 .

- ameria, 22.

- amisena, 6 .

- ammon, 143.

- amphimuta, 90.

__ anarte, 81, 125.

- andersonii, 17.

- anita, 18.

- annetta, 19.

- anna, 19.

- anniella, 114.

- annulata, 52.

- anthelus, 77, 78 .

- - saturatior, 76, 77 .

- anthore, 58.

- antimuta, 98 .

- anunda, 76 .

- apidanus, 115.

__ araxes, 43.

-_ areste, 119.

- aricia, 87.

- aroa, 85 . 
Amblypodia aronya, 57.

- arracana, 18.

- arvina, 147.

- asopia, 138.

- ate, 29.

- atkinsoni, 21.

- atosia, 87.

—atrax, 130.

- aurea, 106.

- auxesia, 80.

- axiothea, 153.

- azenia, 140.

— bazaloides, 55.

- bazalus, 119.

- bicolora, 53.

- bupola, 104.

— buxtoni, 60 .

- cceca, 149.

- camdeo, 46.

- canulia, 149.

- capeta, 113.

— entaurus, 39 .

- chinensis, 118.

- corinda, 121.

- courvoisieri, 152.

- critala, 152.

- cryonthe, 34 .

- eupido, 151.

- darana, 18.

- detrita, 123.

- diardi, 113.

- aisparalis, 152.

- dodonea, 134.

- elfeta, 48.

- epimete, 141.

- epimuta, 88, 89.

- erebina, 52 .

- eridanus, 49 .

- - dilutior, 49.

- eucolpis, 141.

eumolphus, 104.

eupolis, 41.

faisina, 19.

farquhari, 104.

fruhstorferi, 80.

fulgida, 114.

fulla, 150 .
Amblypodia ganesa, 146.

- grynea, 102.

hainana, 20.

helius, 58.

-_— anthelius, 58.

hellenore, 104.

hercules, 28.

- hesba, 95.

- horsfieldi, 107.

- hypomuta, 99.

- inornata, 91.

- kuhni, 113.

- lycanaria, 60 .

- meander, 32.

- metamuta, 100.

micale, 36.

minnetta, 60.

muta, 101.

myrtale, 63.

myrtha, 61.

myrzala, 143.

nakula, 39.

narada, 16, 162.

_- erichsonii, 18.

- naradoides, 18.

nobilis, 74, 75.

oberthuri, 101.

- onea, 130.

- oenotria, 124.

- olinda, 60.

- ovomaculata, 95 .

padus, 46.

- palowna, 6.

paraganesa, 144.

perimuta, 139.

- phryxus, 58.

- polita, 49.

- pryeri, 86.

- pseudo-centaurus, 39.

- pseudomuta, 87 .

- querceti, 130.

- quercetorum, 4, 5 .

—quercoides, 68.

- rama, 130.

- ribbei, 34 .

- rochana, 12.

- selta, 84 . 
Amblypodia sithetensis, 72.

- sophax, 58.

-_ sophrosyne, 36.

- strophe, 153.

- supcrba, 36 .

—_tamyrus, 58.

- taooana, 16, 17.

tephlis, 53, 55.

- theha, 56.

- timoteon, 9 .

- tounguva, 138.

- tristis, 52.

—_ viardi, 113.

— vihara, 66 .

— viola, 46.

_ـ violacea, 130.

- vivarsa, 5,6 .

—_viviana, 61.

- yendava, 125.

- zeta, 135.

- (Narathura) fulla andamanica, 151.

Ambulyx postica, 165, 174, 188.

Amphilius platychir, 540.

Ancistrus, 221, 251.

- alternans, 229.

- angulicauda, 241.

- annectens, 225,330 .

- aspidolepis, 230.

- aurantiacus, 236.

bachi, 233.

barbatus, 240.

brachyurus, 231.

calamita, 258.

- chagresi, 256.

— cirrhosus, 256.

- depressus, 240.

- dolichopterus, 254 .

- duodecimalis, 229.

etentaculatus, 226.

gibbiceps, 227.

gigas, 230.

- guacharote, 238.

guentheri, 241, 332.

- gymnorhynchus, 254.

- heteracanthus, 237.

- hoplogenys, 255.

- ieucostictus, 255.
Ancistrus lituratus, 227.

- longimanus, 226.

- medians, 229.

- megacephalus, 234.

- multiradiatus, 228.

- mystacinus, 238.

- niveatus, 235.

—_ oligospilus, 232, 332.

- parahyba, 241.

— pictus, 231, 237.

- platycephalus, 235, 332.

- punctetissimus, 236.

- punctatus, 229.

- scaphirhynchus, 231.

- schomburgkii, 233.

—_etosus, 239, 332.

- stigmaticus, 259.

- temminckii, 254.

- undccinatis, 226.

- vittatus, 232.

Anthercea belina, 169.

Anthropopithecus niger, 513.

Apporasa, 20.

- atkinsoni, 21.

Arctitis binturong, 500, 501.

Arges, 307.

- boulengeri, 310 .

__ brachycephalus, 313, 350.

- chotce, 313, 350.

- cyelopum, 311.

_- eigenmanni, 312, 350.

_ festce, 316, 350.

— fissidens, 316.

- guentheri, 310,350 .

- homodon, 309, 350.

—_ongifilis, 314

- marmoratus, 314, 350.

- orientalis, 313,350 .

- peruanus, 317.

- prenadilla, 316.

— sabalo, 315.

— simonsii, 317,350 .

—_taczanowskii, 315 .

— vaillanti, 312.

- whymperi, 311, 316.

Arhopala, 1, 25.

aberrans, 144. 
606

Arropala aboe, $14 \pi$.

- abseus, 112.

__ ace, 123.

- acestes, 121.

- ucetes, $45,160$.

— achelous, 82.

- acron, 140, 160.

- adala, 148.

- aclatlsa, 30, 36, 69 .

_ ctherbal, 32 .

- admete, 141.

- vvaigoensis, 141, 160.

adonias, 102, 158.

-adorea, 67.

- adriana, 117, 164.

- adulans, 148.

- vedias, 124, 160 .

- expone, 35, 160.

- agaba, 83.

- agelastus, 89, 136.

- agesias, 95, 160, 16!.

- ayesilcus, 64, 93, 158, 164.

- aglais, 44.

- agnis, 82, 125.

- agrata, 123.

- aida, 64 .

- alaconia, 101.

- albopunctata, 60 .

- alce, 76, 164.

— alesstes, 75 .

- alea, 133.

- alemon, 133, 164.

— alesia, 102.

- aliteeus, 61,16 ?.

- allata, 128, 160.

-alpha, 69.

amantes, 42, 162.

amatrix, 42.

- amazona, 40.

- ammon, 143.

- ammonides, 143, 160.

- amphea, 112

- amphimuta, 90, 158.

—amytis, 33, 34, 162.

- anamuta, 128, 160 .

- ancrte, 81 .

- andamanica, 151, 162.
INDEX.

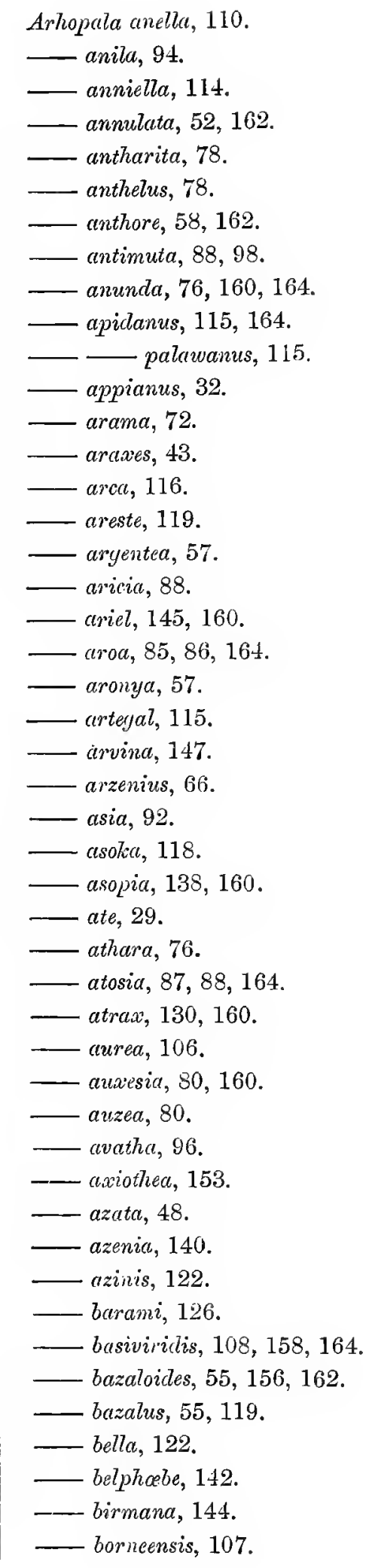


Aihopala brahma, 99, 158.

- brookei, 8t, 156.

- buddha, 148, 160.

- buruensis, 122 .

burtoni, 60 .

- ceccl, 149 .

_ camdeo, 46 .

- canaraica, 133.

— canulia, 149, 160.

- carolina, 50.

- catori, 92, 93, 158, 164.

- centaurus, 39, 162.

- - coruscans, 39 .

— chinensis, 118, 160, 164.

__ clarissa, 57 .

- comica, 134 .

___ constancece, 33.

—_ corinda, 102, 121, 160.

- coruscans, 40 .

- critala, 152.

- cryonthe, 34 .

- dajagaka, 127.

- davaona, 96, 158.

- davisoni, 88, 98.

- detrita, 123.

- deva, 98, 164 .

- diardi, 113, 164 .

— disparalis, 152.

- clodonea, 134, 164.

- dohertyi, 64, 156, 162.

- drucei, 69 .

- duessa, 143.

_ elfeta, 48 .

- elopura, 86, 164.

epimete, 141, 160.

epimuta, 88, 158, 164.

eridanus, 47, 49, 156, 162 .

eumolphus, 104, 158, 164.

__. eupolis, 41, 156.

-_ eurisus, 31.

- farquhari, 104, 105.

___ fruhstorferi, 80.

__ fulgida, 114.

- fulla, 150 .

_- ganesa, 146, 162.

- Loomisi, 146.

—— seminigra, î́6̂.
Arhopala gunonyensis, 97, 158.

- havilancli, 82.

- helianthes, 58.

- helius, 58, 156 .

- - anthelius, 58, 156 .

- hellenore, 10 t, 105.

- hercules, $29,162$.

- - herculina, 28, 156.

$-l_{e o,} 28$.

- tyrannus, 29.

- hesba, 95, 160.

- hewitsoni, 132, 160, 164.

- horsfieldi, 106, 107, 108, 158.

- hylander, 31.

—_hypomuta, 91, 98, 99, 158.

— ijauensis, 80, 156.

- inornata, 91, 158.

— irregularis, 111, 158.

- japonica, 134, 160, 162.

_Llchanti, 129.

- kiviwinii, 38, 156.

—— kounga, 122.

- kuhni, 113, 158.

— kurzi, 92.

- labuana, 65.

leo, 28.

- loomisi, 146.

lycenaria, 60.

- malayica, 71, 158.

- meander, 31, 32, 162.

metamuta, 97, 100, 164 .

- micale, 36.

- mindanensis, $62,1.56$.

- minnetta, 60 .

- mirabella, 61.

- moelleri, 118.

- mooluiana, 89, 158.

- moorei, 97, 164 .

- morphina, 117, 158.

- muta, 101, 164.

- myrtale, $63,156$.

- myrtha, 61, 156.

- myrzala, 143.

- nakula, 39.

- nicévillei, 73, 158.

- nobilis, 74, 158.

- oberthuri, 101, 158. 
Arhopala ocrida, 102.

- oeta, 139.

oenea, 130, 164.

anotria, 124, 160.

olinda, 60.

opalina, 51.

ovomaculata, 95.

padus, 46, 156, 162.

- paraganesa, 144, 162.

- paramuta, 135, 162.

- pastorella, 88, 89.

- periander, 30 .

- perimuta, 139.

- perissa, 137, 160 .

— phcenops, 68, 156.

- philander, 30, 162.

- phryans, 58.

- pirama, 40.

- pirithous, 40.

- pryeri, 86.

- pseudncentaurus, 40 .

- pseudomuta, 86, 87, 156.

-quercoides, 68, 156.

___ rafflesii, 86 .

- rama, 130, 164.

- roone, 136.

- sandakani, 69 .

- sangira, 57, 156.

- sceve, 85 .

- selta, 84 .

- semperi, 126.

__ sithetensis, 72.

- similis, 94 .

- singla, 120, 164 .

- sophrosyne, 36 .

—_ staudingeri, 109, 158.

- subfasciata, 80 .

- superba, 36.

- tameanga, 126.

teesto, 119.

tephlis, 53, 1อ6, 162.

theba, 56, 162 .

tounguva, 138, 160.

- triangularis, 114.

_ trogon, 107.

-

- tyrannus, 28.
Arhopala vihura, 66, 158.

viola, 51, 156, 160.

— v-major, 93.

- waterstradti, 97.

—— wildei, 151, 156.

- wimberleyi, 102.

—yendava, 125.

- zephyretta, 145 .

- zeta, 135.

- (Mahathala) ameria, 22.

Asprotilapia leptura, 542, 565.

Astroblepus, 318.

- grixalva, 318.

Ateles variegatus, 509, 510.

Atherura africana, 484.

Auchenoglanis biscutatus, 553. occidentalis, 540, 553.

- - tanganicanus, 553, 584.

Babirussa babirussa, 469, 471, 519, 520.

Baker, G. T. Bethune-, see Bethune-Baker.

Barbus platyrhinus, 540 .

- serrifer, 540,549 .

- tropidolepis, $540,549$.

Barilius moorii, $5+0,549$.

- tranganica, 540 .

Basiana postica, 174.

Bassaris astuta, 496.

Bathybates f'sciatus, 541, 564, 565.

- ferox, 541, 564, 565 .

— minor, 541, 564, 565, 594.

Bethune-Baker, G. T., Revision of the Anllypodia Group of the IJcænidæ, 1.

Bettongia cuniculus, $449,451$.

- penicillata, $449,450,451$.

Bomby $x$ astreas, 180.

- bauri, 180.

bellatrix, 182.

delegoryuei, 172 .

meters, 178 .

- patens, 173.

- vaillantina, 182.

Boulenger, G. A., on the Varieties of the WallLizard (Lacerta muralis) in Western Europe and North Africa, 351; on the Fishes colleoted by Dr. W. A. Cunnington during the Third Tanganyika Expedition, 537.

Bradypus infuscatus, 455, 456, 517. 
Brontes, 307.

—_ prenadilla, 313, 316.

Buncea tyrrhena, 171, 186.

Butterflies, revision of the Amblypodiv group of, 1 .

Byblia ilithyia, 166, 186.

Callioratis bellatrix, 182, 190.

Callithrix cuprea, 509, 520, 521.

Camolus dromedarius, 473.

Canis familiaris, 498.

- vulpes, 497, 498.

Capoëta tanganica, 549.

Capromys pilorides, 487.

Castor fiber, 482, 517.

Cavia porcellus, 484, 485.

Cebus fatuellus, 509, 510, 520, 521.

Centetes ecaudatus, 491, 492.

Cercoleptes caudivolvulus, 495, 496.

Cercopithecus niger, 511.

- stairsi, 511.

- verneri, 511, 512.

Cervus axis, 474.

Choerocampa eson, 175, 190. orpheus, 165, 176, 188. osiris, 176.

Chatostoma, 244.

Chretostomus, 222, 244, 251, 259.

- aculeatus, 230.

alga, 255.

- anomalus, 250, 334.

- aspidolepis, 230.

- aurantiacus, 236.

— bachi, 233.

- brachyurus, 231.

- branickii, 250.'

brevis, 247, 334.

calamita, 258.

cirrhosus, 256, 257.

cochliodon, 243.

dentex, 243.

depressus, 240.

dermorhynchus, 248.

dolichopterus, 254.

fischeri, 248.

fordii, 261.

gibbiceps, 227.

gibbosus, 243.

gigas, 230.
Chatostomus guacharote, 238.

- guairensis, 249.

— gymnorhynchus, 254.

- heteracanthus, 237.

- loplogenys, 255.

- hystrix, 261.

- itacua, 234.

- jelskii, 258.

Latifrons, 253.

—_ leucostictus, 255.

—_ituratus, 227.

—_loborhynchus, 246.

- macrops, 234.

—_ maculatus, 246, 336.

- malacops, 255.

- marcapatce, 246, 336.

- marginatus, $249,334$.

- medinns, 229.

- megacephalus, 234.

— microps, 247, 249, 251, 336.

- mystacinus, 238.

- nigricans, 236.

- nigrolineatus, 244.

- niveatus, 235.

- nudiceps, 254.

- nudirostris, 251.

—_ oligospilus, 232.

— pictus, 231.

- platycephalus, 235.

- punctatissimus, 236.

- punctatus, 229.

- scaphirhynchus, 231.

- sericeus, 252.

serratus, 260.

- setosus, 239.

- spinosus, 260.

- stannii, 248.

- taczanowskii, 247.

- tectirostris, 255.

- thomsoni, 250, 336.

- trinitatis, 238.

—undecimalis, 226.

- variolus, 256.

- vittatus, 232.

Chatoethiops, 550.

Charaxes vuranes, 168, 186.

Chirogaleus cocquereli, 503, 505.

vol. XVII.-PART vI. No. 10.-October, 1906. 
Chiromys, 536.

Chromis paterfamilias, 538.

- (Tilapia) philander, 538.

Chrysichthys brachynema, 540, 551 .

- eranchii, 540.

- furcatus, 552 .

- myriodon, 540 .

- sianena, 540, 551, 582.

Cirina forda, 170, 186.

Citharinus gibbosus, 540, 548.

Clarias liocephalus, 540.

- robecchii, 540, 550 .

Cochliodon, 242.

- cochliodon, 242.

Copaxa flavinata, 170, 172, 186.

Crenis boisluvali, 167, 186.

— natalensis, 167, 186.

Cricetus frumentarius, 482, 483.

Cryptoprocta ferox, 500, 501.

Cunnington, W. A., on the Fishes collected during the Third Tanganyika Expedition by, 537.

Cunningtonia, 573.

— longiventralis, 542, 574, 600 .

Cyclopium, 307.

- cyclopum, 312.

- guentheri, 310 .

- humboleltii, 311.

Cyclothurus didactylus, 516.

Cynictis penicillata, 500, 501.

Cyronycteris collaris, 492.

Daman, 535.

Darapsa marginata, 177.

Darasana, 25.

- newara, 135.

_- perimuta, 139.

Dasypus minutus, 458, 4อ๊9, 516, 518, 519.

- sexcinctus, 516 .

- villosus, 458, 459, 516.

Dasyurus viverrinus, 446,447 .

Delturus, 222.

- angulicauda, 241.

- parahyba, 241.

Deudorix mocenas, 11.

- timoleon, 11, 12.

Didelphys virginiana, 445 .

Dinotopterus, 550.

— cunningtoni, 540, 550, 580 .
Dipus agyptius, 482.

Dolichotis patachonica, 484, 487 .

Dromicia nana, 449.

Echidna, 442, 525. hystrix, 444.

Ectodus descampsi, 541, 568.

- melanogenys, 569.

Egybolis vaillantina, 182, 190.

Elephas africanus, 466.

Enantiopus, 569.

- longianalis, 537, 538, 541, 565, 569.

- melanogenys, 541, 569 .

Equus granti, 479, 480.

Eretmodus cyanostictus, 537, 542, 574,

Erinceceus algirus, 491.

Estigmene atropunctata, 179, 188.

- dissimitis, 165, 179, 188.

Euchloris devocata, 184, 190.

Europe, on the varieties of the Wall-Lizard of Western, 351.

Eurytela hiarbas, 166, 186.

Farlowella, 302.

- acus, 304.

- amcazonum, 305.

— carinata, 305 .

- gladiola, 305, 348.

- gladius, 303.

- gracilis, 303, 348.

- knerii, 304.

- oryrhynchus, 304.

Fawcett, Lt.-Col. J. M., on Transformations of SouthAfrican Lepidoptera, 165.

Felis caracal, 501, 502 .

- serval, 501.

Fishes, monograph of the Loricariida family of, 191.

-.- of the Third Tanganyika Expedition, 537.

Flos, 25.

- ahamus, 115.

- artegal, 115.

Galago garnetti, 506, 507.

Galeopithecus, 535 .

Galictis barbara, 495.

Gazella dorcas, 474.

- marica, 518.

Geometra devocata, 184.

Gephyrochromis moorii, 542. 
Giraffa cameloparclatis, 474, 475 .

Gorilla savagei, $513,514$.

Grammatotria lemairii, 541, 565, 569.

Gynanisa maia, 171.

Hapale penicillata, 508.

Haplochilus pumilus, 540, 543, 554, 582.

- tanganicanus, 540, 547, 554 .

Haplochromis desfontainesii, 539.

- ishmaeli, 539.

Haplotarodon, 565.

microlepis, 541, 566, 594.

Hartia, 297.

L loricariiformis, 298.

Hemiancistrus, 221, 259.

- aspidolepis, 230.

brachyurus, 231.

_ fordii, 261.

- guacharote, 239.

— heteracanthus, 237.

- hystrix, 261.

—_itcura, 234.

_longipinnis, 235.

- medians, 229.

- megacephalus, 234.

mystacinus, 238.

oligospilus, 232.

pictus, 231.

— scaphirhynchus, 231.

- schomburgkii, 233.

- serratus, 260.

- spinosus, 260.

- trinitatis, 239.

— vittatus, 232.

Hemiloricaria, 270.

- earacasensis, 270.

Hemiodon, 296.

- acipenserinus, 296. depressus, 296.

- platycephalus, 295.

Hemiodontichthys, 296.

__ acipenserinus, 296. depressus, 296.

Hemipsilichthys, 220.

- gobio, 221.

Henucha delegorguei, 172, 186.

- smilax, 171, 186.

Herpestes albicauda, 500, 501.
Herpestes griseus, 500, 501.

- ishneumon, 500, 501.

Hesperia apidanus, 115.

- centaurus, 39.

- mecenas, 11.

Heterolranchus, 550.

Hisonotus, 265.

lovior, 268.

- leptochilus, 268.

- notatus, 268.

Hycena crocuta, 498, 499.

Hydrochorus capybara, 484, 486, 53 อ̄.

Hydrocyon lineatus, 540, 547.

Hyloicus juniperi, 177, 188.

Hypoptopoma, 263.

— bilobatum, 263, 265.

- carinatum, 264.

- guentheri, 264, 333.

- gulare, 265.

- joberti, 265.

— steindachneri, 265.

thoracatum, 263, 265.

Hypostomus, 202, 221, 244, 251, 259.

- alatus, 211 .

- asperatus, 217 .

- aurantiacus, 236.

- auroguttatus, 217.

- barbatus, 240.

— bufonius, 258.

- calamita, 258.

_- cirr.hosus, 256.

—_ochlioclon, 242.

- commersonii, 206.

- duodecimalis, 226.

- emarginatus, 210.

—_ erinaceus, 251, 252.

- ctentaculatum, 226.

- granosus, 306.

- guacari, 205.

- guacharote, 238.

- guttatus, 240.

- horridus, 210.

- itacua, 234.

-_. nigricans, 236.

— niveatus, 235.

- nucliceps, 254.

— pantherinus, 209. 
Hypostomus parda7is, 228.

— pictus, 237.

- plecostomus, 205, 209.

- punctatus, 207.

- robinii, 205, 215.

- serratus, 260.

- spinosus, 260.

- squalinum, 210.

- subcarinatus, 207 .

- temminckii, 254.

- vicinus, 236.

Hyrax capensis, 460, 461, 516.

IIystrix cristata, 484.

Ichthyology of Lake Tanganyika, 537.

Ictonyx zcrilla, 495.

Indris brevicaudatus, 503.

Intestinal Tract of Mammals, 437.

Iois, 25.

Iraota, 1, 8, 16.

- boswelliana, 12.

—_ lazurena, 13, 156.

- macenas, 10, 11.

- nila, 14.

- rochana, 12.

- timoleon, 9, 10, 11, 12, 162.

Julidochronis ornatus, 541.

Labeo cylindricus, $540,543,548$.

_ forskalii, 548.

Lacerta acrolampra, 403.

_- ayilis, 373, 389, 392 .

__bedriago, $369,410,411,413,420$.

- bruggemanni, 384 .

— depressa, 354, 359, 368, 369.

- derjuginii, 380.

- faraglionensis, 394.

_ filfolensis, 401.

- genei, 377, 405, 413 .

- horvathi, 358, 365, 366, 367, 378 .

___ lilfordi, $372,373,376$.

mosoriensis, 366.

- muralis, 351-436.

—_ balearica, 369, 370, 372, 373.

-_— pityusensis, 370.

- - bedriago, 384, 404, 409, 411, 413, 414, $415,424,434,436$.

- Zocagei, $361,369,415,416,420,426$, 428,436 .
Lacerta muralis breviceps, 376, 378, 379, 420, 428.

- brueggemanni, 376, 377, 380, 381, 383, $384,386,387,388,389,394,401,404,405$, $420,422,424$.

- campestris, 380, 388, 389, 390, 391, 392, $394,395,396,397,399,404,405,420,432$,

434.

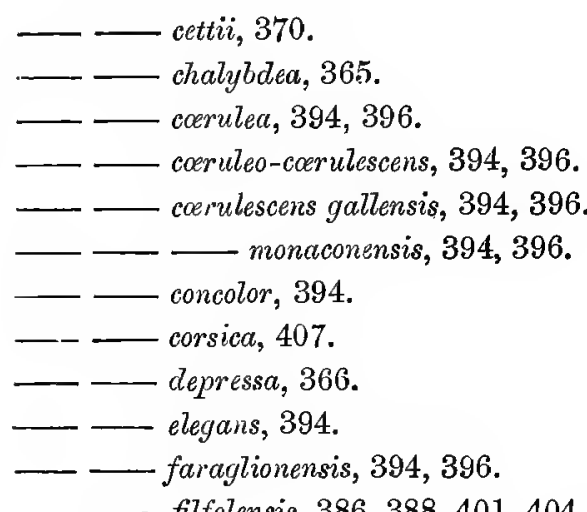

__ _ filfolensis, 386, 388, 401, 404, 420, 432, 434.

- fiaviundata, 384, 385, 386 .

- - fusca, 361, 368, 372, 373, 376, 398, $405,406,415$.

$-\longrightarrow$ corsica, 406 .

- nigriventris, 384 .

- genei, 406 .

- - gigliolii, 369, 372, 373, 374 .

- - hispanica, 363, 368, 369, 420, 426, 428.

- latastii, 394.

—— lilfordi, 369, 372, 373, 420, 424, 430.

- - liolepis, 363, 368, 369, 416, 420, 426

428.

- livornensis, 392.

maculata, 394.

- - - - reticulata, 410 .

$\longrightarrow-$-tigris, 410 .

- maculato-striata, 394.

- milensis, 408.

- - modesta, 394, 396 .

- - monticola, 365, 366, 369, 420, 426, 428 .

- - multifasciata, 390, 392.

- naxensis, 408.

- neapolitana, 377, 380, 381, 384, 387, $388,394,406$.

- - campestris, 390.

- lineata, 406 .

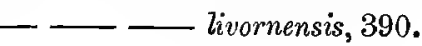


Lacerta muralis neapolitana nigriventris, 384.

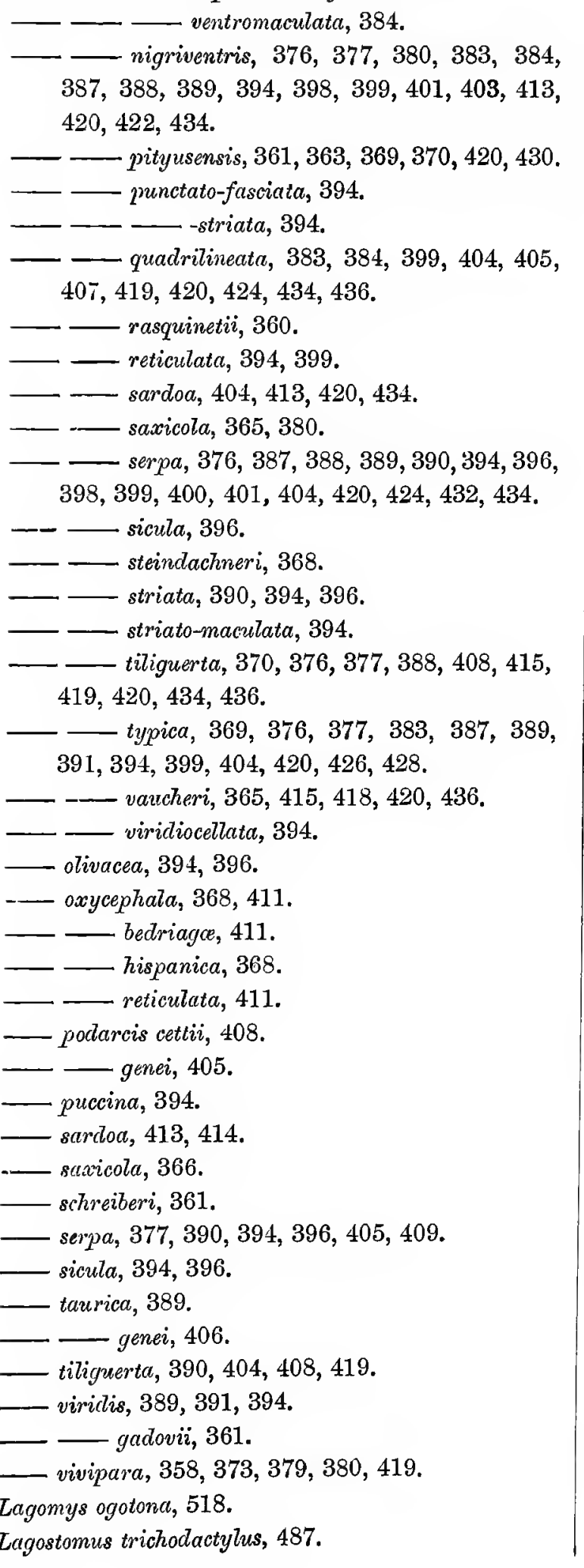

Lama huanaco, 473.

Lamprologus brevianalis, 541, 555, 562, 590.

brevis, 541, 561.

— callipterus, 541, 559, 560, 562, 590.

- - calliurus, 541, 560, 562, 588.

- compressiceps, 541, 561, 562.

— cunningtoni, 541, 557, 562, 590.

- elongatus, 541, 556, 557, 562 .

fasciatus, 541, 562.

_urcifer, 541, 562 .

- hecqui, 541, 559, 560, 562.

- lemairii, 541, 556, 558, 560, 562.

- modestus, 541, 558, 562.

- mondabu, 541, 557, 562, 590.

moorii, 541, 562 .

- multifasciatus, 541, 558, 562, 588 .

- reticulatus, 541, 560, 562, 588 .

- tet'clcanthus, 541, 556, 562.

- tretocephalus, 541, 557, 562 .

Lasiancistrus, 224.

Lates angustifrons, 541, 555, 588.

- microlepis, 541, 555, 588.

Lemur mongoz nigrifrons, 503, 504.

- rufifrons, 503.

Lepidoptera, on transformations of South-African, 165.

Lepus cuniculus, 488, 489.

- timidus, 517.

Liposarcus, 222.

- altipinnis, 227.

- jeanesianus, 228.

- multiradiatus, 228.

- pardalis, 228.

- scrophus, 227.

—- varius, 228.

Lizard (Wall-), on the West-European and NorthAfrican varieties of, 351.

Lophuron marginatum, 177, 188.

Loricaria, 270, 273.

- acipenserina, 296.

- acuta, 287.

- amazonica, 286.

- anus, 289.

- apeltogaster, 292.

— aurea, 301.

-_ barbata, 301.

_ bransfordi, 270 . 
Loricaria brevirostris, 299.

-_ brunnea, 270.

- cadec, 279.

- carinata, 292.

- castanea, 287, 288.

- catanarcensis, 280.

- cataphracta, 291.

- cirrhosa, 286, 291.

- depressa, 296.

- clura, 291.

- evansii, 290.

- filamentosr, 274, 292.

- flava, 205.

- frenata, 302.

- jubata, 278, 338 .

- Konopickyi, 281.

labialis, 283.

- laviuscula, 284, 285.

- lamina, 294, 295.

- lanceolata, 277.

laticeps, 295, 348.

latirostris, 283, 340.

—_ lima, 281, 282.

- macrodon, 293.

- macromystax, 294.

macrops, 290, 342.

- mavulata, 286.

- magdalena, 279.

— microlepidogaster, 283, 338.

— nigricauda, 275, 340 .

- nudirostris, 288.

- nudiventris, 290.

- panamensis, 301 .

- parahemiodon, 286.

- parva, 276.

- paulina, 283.

- phoxocephala, 276 .

- platycephala, 295.

- platystoma, 298.

- platyura, 270.

- plecostomus, 205.

- punctata, 285, 342 .

- rostrata, 290, 300, 301 .

_._ setifera, 291.

—_ simillima, 292, 342.

- spixii, 289.

__ steinclachneri, 281.
Loricaria strigilata, 283.

- stubelii, 287.

- teffeara, 280.

- typus, 286, 287.

- uracantha, 278.

- valenciennesi, 286.

- variegata, 293.

- vetula, 293.

Loricariichthys, $270,273$.

maculatus, 286.

Loricaviida, revision of the Fishes of the family, 191.

Ludia smilax, 170.

Lutra vulgaris, 495.

Lycoena japonica, 134.

Lycenidce, revision of the Amblypodia group of the 1.

Macacus arctoides, 511.

-rhesus, 511, 520, 521.

Macropus bennettii, 449, 452, 517.

Mahathala, 1, 20.

- ameria, 22, 162.

- atkinsoni, 21.

- gone, 23 .

- hainani, 23, 156.

- (Apporasa) atkinsoni, 21.

Mrlopterurus electricus, 540, 554.

Mammals, on the Intestinal Tract of, 437.

Manatus inunguis, 464, 516.

Manis tricuspis, 454.

Marcusenius discorhynchus, 54 j.

- petherici, 545.

- tanganicanus, 540, 545, 578.

Mastacembelus congicus, 576 .

—unningtoni, 542, 575, 576, 600 .

_ellipsifer, 542, 576.

- frenatus, 542, 576 .

moorii, 542, 575, 576.

- ophidium, 542, 576.

- toniatus, 542, 576.

- tanganica, 542, 576 .

Megaderma, 492.

Metanastria aculeata, 180, 188.

Metarctia meteus, 165̄, 178, 188.

Microlepidogaster, 265.

- perforctus, 269.

Microthrissa, 547.

Midas rufimanus, 508. 
Nitchell, P. C., on the Intestinal Tract of Mammals, 437.

Mormyrus caschive, 546. longirostris, $5 \pm 0,546$.

Irus arboricola, 482, 483.

- decumanus, 482, 483.

Muscardinus avellanarius, 482.

Mustela subpalmati, 495.

Mycetes beelzebul, 509, 519, 520.

- sericulus, 509.

Myrina lazarena, 13.

Myrmecophaga didactyla, 516.

Nandinia binotata, 500, 501.

Narathure, 25.

- achelous, 82.

- agelastus, 89, 136.

- agnis, 125.

- albopunctata, 60.

- amaria, 22.

- ammon, 143.

- amphinuta, 86.

- anniella, 114.

- anthelus, 76, 78 .

- aroa, 85.

- atosia, 87 .

- buxtoni, 60 .

__entaurus, 39.

- farquhari, 104.

- - inornata, 91.

- kurzi, 92.

- lyconaria, 60.

- maxwelli, 104.

- metamuta, 100.

- moolaiana, 89.

—_ roona, 136.

_ subfasciata, 151.

— vihura, 66.

Nasalis larvatus, 511.

Nasua vittata, 496.

Neobola, 543, 550 .

- argentea, 550 .

- bottegi, 550 .

- minut $a, 540,549,550,582$.

Neoplecostomus, 306.

- granosus, 306.

- microps, 306.

Nephele variegata, 177, 188
Nilasera, 25.

- adriana, 117.

- amantes, 42.

- apella, 42.

- areste, 119.

- asoka, 118.

- centcurus, 39.

— fulgida, 114.

- moelleri, 118.

- opalina, 51 .

— pirama, 39.

— pirithous, 39.

- subfasciata, 80 .

- wimberleyi, 102.

Nudaurelia belina, 169, 186.

Ochotona pusilla, 517.

- rufescens, 440, 488, 518.

Oclaxothrissa, 547.

Ophiusa demta, 183.

- indeterminata, 183, 190.

Ornithorhynchus anatinus, 442, 443, 525.

Orycteropus, 453, 460.

Otaria californiana, 493, 494.

Otocinclus, 265.

- affinis, 267.

- fimbriatus, 267.

- flexilis, 267.

- joberti, 265.

- lophophanes, 269.

- maculicauda, 268.

- nigricauda, 268.

- notatus, 268.

- perforatus, 269.

- vestitus, 267.

— vittatus, $267,338$.

Ouacaria rubicunda, 509, 511.

Ovis tragelaphus, 474.

Oxyloricarice, 297.

- barbata, 301.

_ brevirostris, 299.

_ frenata, 302, 344.

- guentheri, $299,344$.

— loricariiformis, 298.

_L lyra, 300, 346.

panamensis, 301.

platystoma, 298.

__obusta, 300, 346. 
Oxyloricaria rostrata, 300.

Oxyropsis, 263.

-_wrightiana, 264.

Panaque, $2+2$.

- cochliodon, 242, 243.

- dentex, 243.

- gibbosus, 243.

- nigrolineatus, 244.

Panchala, 25.

- apidanus, 115.

_ birmana, 144.

- diardi, 113.

- _. doclonea, 134.

—-ganesa, 146.

- morphina, 117.

- paraganesa, 144.

- paramuta, 135.

- rama, 130.

- singapura, 114.

Papilio apidanus, 115.

— centaurus, 39.

_ dorimond, 115.

- eumolphus, 104.

- helius, 58.

- hiarbas, 166.

— ilithyia, 166.

- timoleon, 9.

- varanes, 168.

Paruhemiodon, 270.

- typus, 286.

Parancistrus, 221, 222.

- aurantiacus, 236.

- nigricans, 236.

- punctatissimus, 236.

Paratilapia calliura, 541.

— dewindti, 541, 563.

- frontosa, 541, 561, 592.

_ furcifer, 541, 563.

leptosoma, 541.

longiceps, $\mathbf{5 6 5 .}$

- macrops, 541 .

_- multicolor, 538.

- nigripinnis, 541.

— pfefferi, 537, 541, 563.

- robusta, 565 .

- serranus, 539 .

- stenosoma, 541, 564, 566.
Paratilapia ventralis, 541, 563.

Parotocinclus, 265.

- maculicauda, 268.

Pellonula acutirostris, 547.

— miodon, 540, 546, 578 .

- vorax, 547.

Pelmatochromis auritus, 541, 568, 596.

- lateralis, 538.

- melanostigma, 541, 567, 596.

— pleurospilus, 537, 541, 567, 596.

_ pulylepis, 537, 541, 566, 592.

— rhoclostigma, 541, 568, 596.

Peragale lagotis, 446, 448.

Perissodus microlepis, 542.

Perodicticus potto, 507, 508.

Petaurus sciureus, 449, 517, 518, 519.

Petovia dichroaria, 184, 190.

Petrochromis polyodon, 542, 573.

- tanganices, 542, 573.

Petrogale penicillata, 449, 451.

Phacochoerus othiopica, 469, 470.

Phalangista vulpina, 449, 450.

Phascogale penicillata, 446.

Phascolomys, 449.

Phoce vitulina, 493.

Phocona communis, $467,468$.

Plyllalia flavicostata, 173, 186.

— patens, 165, 173, 186.

Phyllonemus, 552.

- typus, 540, 552, 583.

Pieris abyssinica, 168.

- gidica, 168, 186.

Pimelodus cyclopum, 311.

Plecodus paradoxus, 542, 574.

Plecostomus, 202, 203, 221.

- affinis, 207.

- alctus, 211.

- angulicauda, 241.

- annoe, 210.

- asper, 220.

- aspilogaster, 206.

- atropinnis, 215.

- auroguttatus, 217.

- barbatus, 240.

— bicirrhosus, 205, 209.

- biseriatus, 210.

- borellii, 212, 326 . 
Plecostomus boulengeri, 206.

_ brasiliensis, 205.

- brevicauda, 216.

- carinatus, 209.

- cochliodon, 242.

- conmersonii, 206, 207.

- corclova, $212,326$.

- emarginatus, 210 .

- festae, 208, 326.

- flagellaris, 291.

- flavıs, 205.

- francisci, 211.

- garmani, 214, 328.

-__ genibarbis, 219.

- granosus, 306.

- grttatus, 241.

- heylandii, 221.

- horridus, 210.

johnii, 217.

_- latirostris, 213, 330.

— lime , 214, 216, 217.

_Limosus, 206.

—_ luetkeni, 217.

- macrops, 214.

- maculatus, 286.

- microps, 306.

— pantherinus, 213.

- parahybce, 219.

—_ pardalis, 228.

- pellegrini, 218.

- plecostomus, 205, 206.

_ punctatus, 207.

robini, 215.

scabriceps, 207.

scopularius, 210.

seminudus, 206.

spiniger, 206.

spinosissimus, 208.

tenuicauda, 210.

- ternetzi, 213.

- unce, 215.

- vaillanti, 210.

— vermicularis, 216.

— verres, 209.

villarsi, 210.

virescens, 210.

- wertheimeri, 218.
Plecostomus wuchereri, 216, 328.

Plotus, 516.

Podarcis muralis albiventris, 394.

- campestris, 390.

——_ doclerleini, 394.

__ faraglionensis, 394.

- filfolensis, 402.

_—_ lineata, 379, 394, 405.

- mcculata, 394.

—- roseiventris, 380 .

- - sicula, 394.

- - tiliguerta, 409.

—_ viridiocellata, 394.

_ oxycephala, 411.

tiliguerta, 405.

Pogonopoma, 205.

Polyommatus apidanus, 115.

— centaurus, 39.

- eumolphus, 104.

- helius, 58.

- helus, 39.

Polypterus, 543.

- congicus, 540, 544.

Polyptychus grayi, 174, 188.

Porcula salvania, 469, 471.

Potamogale, 491.

Procyon lotor, 496.

Protopterns, 551.

cethiopicus, 540, 544.

Pseudacanthicus, 259.

- fordii, 261.

- hystrix, 261.

- servatus, 260.

- spinosus, 260.

Psendancistrus, 221, 222.

- barbatus, 240.

- clepressus, 240.

- guttctus, 240 .

- setosus, 239.

- vertheineri, 218.

Pseudergolis uedrth, 167.

Pseudlohemiodon, 270.

Pseudoloricaria, 270, 272.

Pteropus gouldi, 492.

- medius, 492.

Pterygoplichthys, 221.

- anisiti, 221.

VOL. XVII.-PART VI. No. 11.-October, 1906. 
Pterygoplichthys duodecinalis, 226.

- etentaculatum, 226.

- gibbiceps, 227 .

- jeanesianus, 228.

- juvens, 221.

- Tituratus, 227.

- multiradiatue, 228.

- pardalis, 228.

- punctatus, 229.

- undecimalis, 226 .

Rapala amisena, 6.

Regan, C. T., Mronograph of the Fishes of the Family Loricariida, 191.

Rhaniclophora cinctigutta, 183, 190.

Rhinelepis, 202, 205, 261.

- acanthicus, 262.

- agassizii, 219.

- aspera, 220.

- genibarbis, 219.

- hystrix, 261.

- lophophanes, 269.

- strigosa, 220.

Rhineloricaria, 270, 271.

Rhinoceros unicornis, 478.

Rhinopoma, 492.

Rhodogastria astreas bauvi, 180, 188.

Rhytinn, 465, 523.

Satadra, 25.

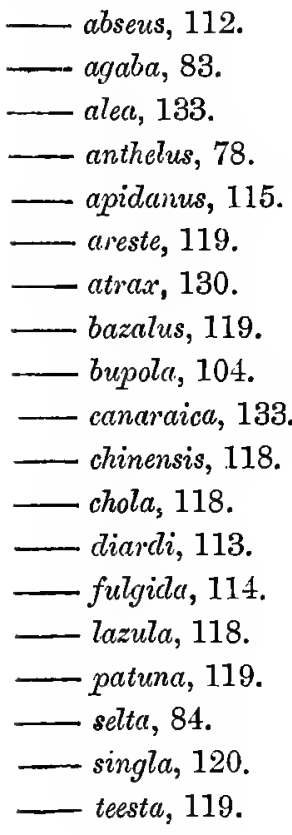

Satadra zetı, 135.

Saturuia forda, 170.

Simia satyrus, 513.

Simochromis diagramma, 537, 542, 571 .

Smerinthus grayii, 174.

Spathodus erythrodon, 542.

Sphingurus prehensilis, 484 .

Sphinx eson, 175.

- juniperi, 177.

Sturisoma, 297.

Stygogenes, 307.

- cyclopum, 311.

- guentheri, 310.

- humboldtii, 310, 311.

Surendra, 1, 3.

- amisena, 4, 6, 7, 156, 162 .

- biplagiata, 5 .

- discalis, 4, 5.

- florimel, $4,7$.

- latimargo, 5 .

- palowna, 4, 6, 7 .

- quercetorum, 4.

- latimargo, 5 .

- stimula, $4,7,8$.

— vivarna, 4, 6, 156.

Suricata tetradactyla, 500, 501.

Sus scrofa, 469, 470.

Synodontis granulosus, 540 .

- melanostictus, 540, 553, 586.

- multipunctatus, 540, 553.

- punctulatus, 554.

— schall, 554.

- zambesensis, 554.

Talpa europaca, 490.

Tamandua tetradactyla, 455, 457.

Tanganyika, Report on the Fishes of the Third Expedition to, 537.

Tapirus americanus, 477 .

Tarsius, 503, 535.

Tatusia keppleri, 458, 516.

Telmatochromis temporalis, 541, 561.

— vittatus, 541.

Thaduka, 1, 24.

- nultimaculata, 20, 24, 162.

Thecla apidanus, 115.

- narada, 16.

- nila, 10. 
Thecla rama, 130. - timoleon, 12.

Tilapia boops, 542, 574 .

- burtoni, 542, 571 .

dardennii, 537, 542, 572. gatilcea, 538.

- grandoculis, 542, 573 .

- horii, 542, 572.

— labiata, 542, 572.

- lata, 572.

- latifrons, 542, 571, 593.

- martini, 539.

_- melanopleura, 572.

-_ microlepis, 542, 572 .

- natalensis, $538,539$.

- nilotica, 538, 542, 571.

- philander, 538, 539.

- pleurotcenia, 542.

- rubro-punctata, 572 . - simonis, 538.

- strigigena, 538.

- trematocephala, 542.

Tinolius eburneigutta, 184.

Trabala pallida, 181, 190.

Tragulus meminna, 471, 472.

Trematocara marginatum, 541, 570.

— nigrifrons, 541, 565, 570, 600 . unimaculatum, 541, 565, 570 .

Tropheus annectens, 542.
Tropheus moorii, 538, 542, 570.

Tupaia tana, 490, 492.

Ursus malayanzs, 496, 498.

Usta terpsichore, 169, 186.

Varicorhinus tanganica, 540, 549.

Vipera aspis, 373.

- berus, 373.

Xenocara, 251.

- brevipinnis, 257.

bufonia, 258.

chagresi, 256, 336.

cirrhosa, 256.

- dolichoptera, 254.

gyinnor-hynchus, 254.

- hoplogenys, 255.

- latifrons, 253, 338.

- montana, $258,336$.

occidentalis, 257, 336.

stigmatica, 259.

temminckii, 254.

Xenochronis hecqui, 542, 574.

Xenomystus, 220.

-gobio, 221.

Xenotilapia ornatipinnis, $5+1,565$. $\operatorname{sima}, 541,565,569$.

Xenurus unicinctus, 458, 459, 516.

Xerus capensis, 480, 481.

Zootoca lilfordi, 372, 375, 401, 402. quadritineata, 405, 408.

END OF VOLUME XVII.

IRINTED BX TAYLOR AND FRANCIS, RED LION COURT, FLEET STREET. 



\title{
TRA NSACTIONS
}

OF

\section{THE ZOOLOGICAL SOCIETY}

\author{
OF LONDON.
}

VOLUME XVII.

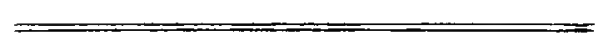

L O N D O N :

PRINTED FOR THE SOCIET'Y :

SOLD AT THEIR HOUSE IN HANOVER-SQUARE;

AND BY MESSRS. LONGMANS, GREEN, AND CO., PATERNOSTER-ROW.

1903-06. 
PRINTED BY TAYLOR AND FRANCIS, RED LION COULT, FLEET STREET. 


\section{O N T E N T S.}

I. A Revision of the Amblypodia Group of Butterflies of the Family Lycænidæ. By George T. Bethune-Barer, F.L.S., F.Z.S., \&c. (Plates I.-V.) · · · page 1

II. Notes on the Transformations of some South-African Lepidoptera. (Continued from the 'Transactions of the Zoological Society of London,' vol. xv. pt. 6, April 1901.) By Lieut.-Colonel J. Malcolm FawcEtT. (Plates VI.-VIII.) 165

III. A Monograph of the Fishes of the Family Loricariidæ. By C. Tate Regan, B.A., F.Z.S. (Plates IX.-XXI.) . . . . . . . . . . . . . . . . I91

IV. A Contribution to our Knowledge of the Varieties of the Wall-Lizard (Lacerta muralis) in Western Europe and North Africa. B.y G. A. Boulenger, F.R.S., V.P.Z.S. (Plates XXII.-XXIX.) . . . . . . . . . . . . . 351

V. On the Intestinal Tract of Mammals. By P. Chalmers Mitchell, M.A., D.Sc., Secretary to the Society . . . . . . . . . . . . . . . . . 437

VI. Fourth Contribution to the Ichthyology of Lake Tanganyika.-Report on the Collection of Fishes made by Dr. W. A. Cunnington during the Third Tanganyika Expedition, 1904-1905. By G. A. Boulenger, F.R.S., V.P.Z.S. (Plates XXX.-XLI.) . . . . . . . . . . . . . . . . . . . . 537

List of the Papers contained in Vol. XVII. . . . . . . . . . .601

Index of Species, \&c. . . . . . . . . . . . . . . . . . . . . 603 



\section{TRANSACTIONS OF THE ZOOLOGICAL SOCIETY OF LONDON (continued).}

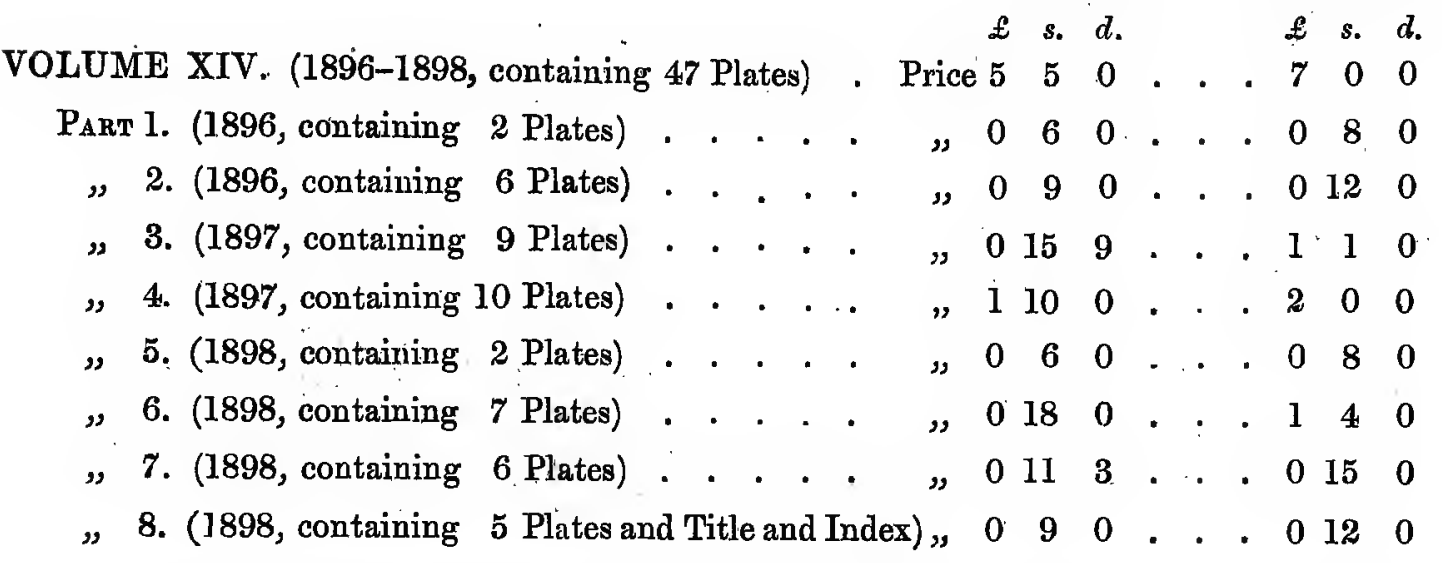

VOLUME XV..(1898-1901, containing 52 Plates) . Price 5156 . . . 7140

Part 1. (1898, containing 8 Plates) . . . . . . „ „ 0159

„2. (1899, containing 5 Plates). . . . . . $\quad \begin{array}{llllllllll} & 0 & 9 & 0 & . & . & 0 & 12 & 0\end{array}$

„3. (1899, containing 4 Plates) . . . . . $\quad \begin{array}{llllllllll}0 & 9 & 0 & . & 0 & 0 & 12 & 0\end{array}$

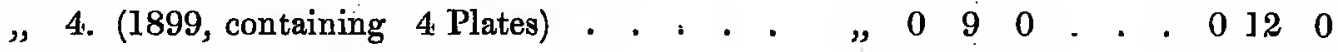

„5. (1900, containing 24 Plates) . . . . . $\quad$ " 2126 . . . 3100

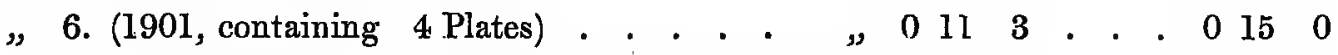

„7. (1901, containing 3 Plates and Title and Index) , $\begin{array}{ccccccccc}0 & 9 & 0 & . & . & 0 & 12 & 0\end{array}$

VOLUME XVI. (1901-1903, containing 38 Plates) . Price $5 \quad 8 \quad 0 \quad$. . . 7440

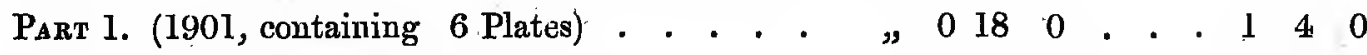

„2. (1901, containing 5 Plates) . . . . . „ „ 0113 . . . 0150

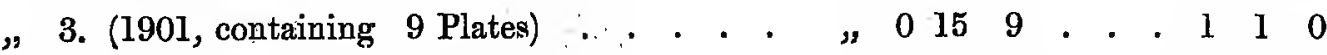

”4. (1902, containing 5 Plates) . . . . . $\quad \begin{array}{llllllllll}0 & 9 & 0 & . & . & 0 & 12 & 0\end{array}$

„5. (1902, containing 4 Plates) . . . . . „ „ 0136 . . . 018180

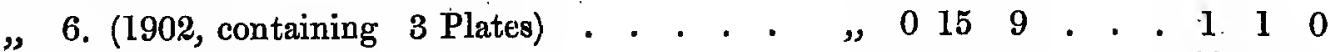

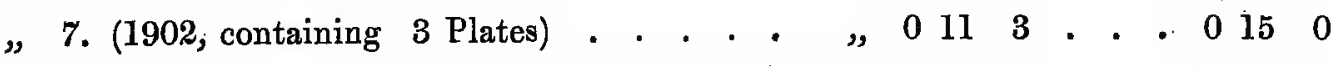

„. 8. (1903, containing 3 Plates andTitle and Index), 0136 . . . 018180

\section{VOLUME XVII.}

PARt 1. (1903, containing 5 Plates) . . . . . Price 126 . . . 1100

„2. (1903, containing 3 Plates) . . . . . $\quad$ „ 0136 . . . 0180

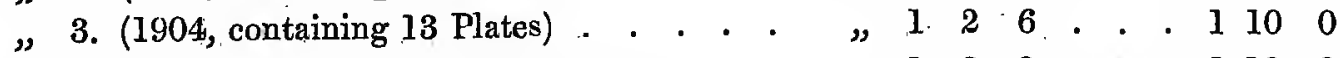

„4. (1905, containing 8 Plates) . . . . . $\quad$ „ 1226 . . . 110

5. (1905, containing 50 Text-figures) . . . $\quad \begin{array}{llllllllll} & 0 & 15 & 0 & . & . & . & 1 & 0 & 0\end{array}$

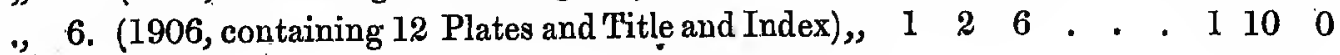




\section{O N T E N T S.}

VI. Fourth Contribution to the Ichthyology of Lake Tanganyika.-Report on the Collection of Fishes made by Dr. W. A. Cunnington during the Third Tanganyika Expedition, 1904-1905. By G. A. Boulenger, F.R.S., I.P.Z.S. (Plates XXX.-XLI.). • • • . . . . . • • • . . • • page 537

List of Papers contained in Vol. XVII. . . . . . . . . . . . . 601

Index of Species, \&c. in Vol. XVII. . . . . . . . . . . . . 603

Titlepage and Contents to Vol. XVII.

THE PUBLICATIONS OF THE ZOOLOGICAL SOCIETY OF LONDON.

The scientific publications of the Zoological Society of London are of two kinds-"Proceedings," published in an octavo form, and "Transactions," in quarto.

According to the present arrangements, the "Proceedings" contain not only notices of all business transacted at the scientific meetings, but also all the papers read at such meetings and recommended to be published in the "Proceedings" by the Committee of Publication. A large number of coloured plates and engravings are issued in the "Proceedings", to illustrate the new or otherwise remarkable species of animals described in them. Among such illustrations, figures of the new or rare species acquired in a living state for the Society's Gardens.are often given.

The "Proceedings" for each year are issued in four parts, in the months of June, August, October, and April, the part published in April completing the volume for the last half of the preceding year. Beginning from January 1901 they form two half-yearly volumes.

"The "Transactions" contain such of the more important communications made to the scientific meetings of the Society as, on account of the nature of the plates required to illustrate them, are better adapted for publication in the quarto form. They are issued at irregular intervals:

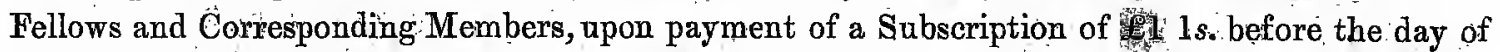
the Anniversary Meeting in each year, are entitled to receive all the Society.'s Publications for the year. They are likewise entitled to purchase the Publications of the Society at 25 per cent, Iess than the price charged for them to the Public. A further reduction of 25 per cent. is made upon purchases of Publications issued prior to 1881 , if they exceed the value of five pounds.

Fellows also bave the privilege of subscribing to the Annual Volume of the 'Zoological Record' for a sum of $£ 110$ s. (which includes delivery), but this privilege only holds good if the subscription is paid before the First of December in eack year.

Such of these publications as are in stock may be obtained at the Society's Office (3 Hanover Square, W.), at Messrs. Longmans', the Sociéty's publishers (Paternoster Row; E.C.), or through any bookseller.

October, 1906.

P. CHALMERS MITCHELL, Secretary. 



